
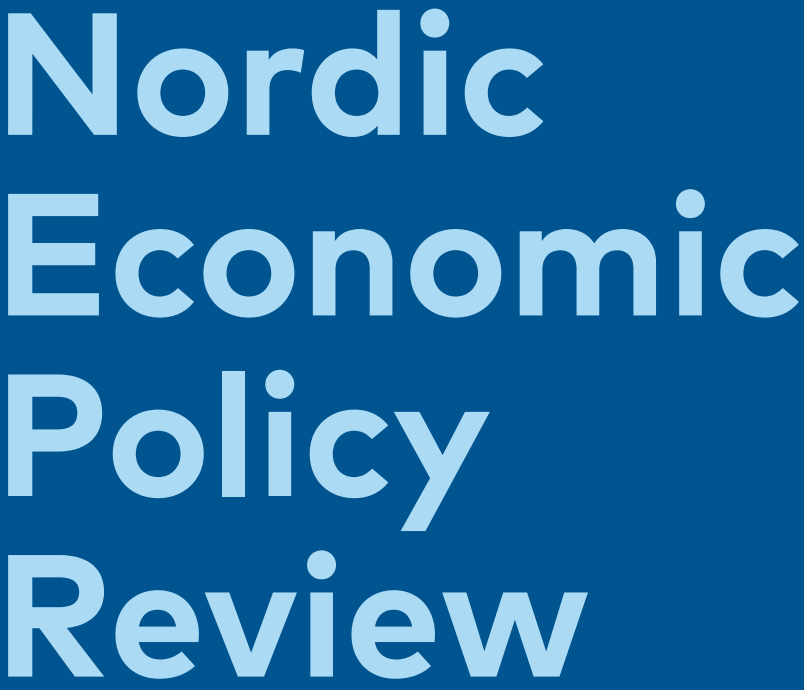

Labour Market Integration in the Nordic Countries

III) Nordic Council of Ministers 



\section{Nordic Economic Policy Review}

Labour Market Integration in the Nordic Countries

Bernt Bratsberg, Oddbjørn Raaum and Knut Røed

Olof Åslund, Anders Forslund and Linus Liljeberg

Matti Sarvimäki

Marie Louise Schultz-Nielsen

Hans Grönqvist and Susan Niknami

Kristian Thor Jakobsen, Nicolai Kaarsen and Kristine Vasiljeva

Joakim Ruist

Torben M. Andersen (Managing Editor)

Anna Piil Damm and Olof Åslund (Special Editors for this volume)

TemaNord 2017:520 


\section{Nordic Economic Policy Review}

Labour Market Integration in the Nordic Countries

Bernt Bratsberg, Oddbjørn Raaum and Knut Røed

Olof Åslund, Anders Forslund and Linus Liljeberg

Matti Sarvimäki

Marie Louise Schultz-Nielsen

Hans Grönqvist and Susan Niknami

Kristian Thor Jakobsen, Nicolai Kaarsen and Kristine Vasiljeva

Joakim Ruist

ISBN 978-92-893-4935-2 (PRINT)

ISBN 978-92-893-4936-9 (PDF)

ISBN 978-92-893-4937-6 (EPUB)

http://dx.doi.org/10.6027/TN2017-520

TemaNord 2017:520

ISSN 0.908-6692

Standard: PDF/UA-1

ISO 14289-1

(C) Nordic Council of Ministers 2017

Print: Rosendahls

Printed in Denmark

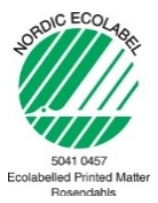

Although the Nordic Council of Ministers funded this publication, the contents do not necessarily reflect its views, policies or recommendations.

\section{Nordic co-operation}

Nordic co-operation is one of the world's most extensive forms of regional collaboration, involving Denmark, Finland, Iceland, Norway, Sweden, the Faroe Islands, Greenland, and Åland.

Nordic co-operation has firm traditions in politics, the economy, and culture. It plays an important role in European and international collaboration, and aims at creating a strong Nordic community in a strong Europe.

Nordic co-operation seeks to safeguard Nordic and regional interests and principles in the global community. Shared Nordic values help the region solidify its position as one of the world's most innovative and competitive. 


\section{Contents}

Foreword by Anna Piil Damm and Olof Åslund

1. Immigrant labor market integration across admission classes

Bernt Bratsberg, Oddbjørn Raaum, and Knut Røed

2. Labour market integration of refugees in Denmark

Marie Louise Schultz-Nielsen

3. Labor market integration of refugees in Finland 91 Matti Sarvimäki

4. Labour market entry of non-labour migrants - Swedish evidence 115 Olof Åslund, Anders Forslund, and Linus Liljeberg

5. The School Achievements of Refugee Children: Lessons from Sweden 159 Hans Grönqvist and Susan Niknami

6. Does reduced cash benefit worsen educational outcomes of refugee children? 185 Kristian Thor Jakobsen, Nicolai Kaarsen, and Kristine Vasiljeva

7. The fiscal impact of refugee immigration..... 211 Joakim Ruist 


\section{Foreword by Anna Piil Damm and Olof Åslund}

It is hardly controversial to say that issues related to asylum seekers, refugees and migration in general have been at the core of the political and media debate in the Nordic countries for some time. Severe and long-lasting conflicts put millions of people on the move, on routes and by means endangering lives and creating humanitarian distress. Increased pressure on immigration systems and authorities create a need for international collaboration but also uncover conflicts of interest and increase tensions between countries and political camps and views. Public opinion combined with pressure on reception systems cause rapid and dramatic shifts in policies in some countries, further affecting the conditions for the migrants and for implementing agencies.

The Nordic countries exhibit both differences and similarities in their histories of migration policies and patterns. Finland's history as an immigration net receiver is shorter than those of the other countries. Norway has experienced particularly substantial economic immigration in the 2000s. While Sweden and Denmark share a long history of policy attempts to handle humanitarian and family related immigration, Denmark's steps toward more restrictive policies started earlier than Sweden's rapid moves in late 2015 .

Figure 1 below shows the absolute number of asylum seekers per month to the respective Nordic countries since 2010. A first observation is that there are clear differences in the levels. In this time period Sweden stands out as the country receiving by far the largest number asylum applications compared to its Nordic neighbours (note that the numbers for Sweden are given on the right-hand side axis). This holds also if one considers the fact that Sweden's population is almost twice as large as that of Norway, Finland, and Denmark respectively. But there are also differences between the three Nordic countries with similar overall populations. During an average month in this time period, Norway received 50 percent more asylum seekers than Denmark. The corresponding figure for Finland compared to Denmark was 30\% less asylum seekers. 
Clearly, the 2015 increase meant an unprecedented situation in all of the Nordic countries connected to Europe's mainland.

In a broader European comparison, however, the Nordic countries are all above average in terms of asylum seekers per capita. In the years 2009-2015 the EU average was about 70 asylum seekers per 10,000 residents, while it stood at about 100 for Finland and Denmark, 200 for Norway and above 400 for Sweden (Dustmann et al., 2016). Note also in Figure 1 that even though there are differences, the variations over time follow similar patterns. In other words, the Nordic neighbours are to a large extent exposed to the same changes due to events in other parts of the world.

Another common factor is that the labour market performance of large groups of migrants has been considered a problem for a long time. A substantial research literature as well as numerous reports from governments and organizations has documented employment and earnings disparities and how they evolve, and tried to understand the sources of inequalities. Within the OECD, the Nordic countries tend to be among the ones with greater negative immigrant-native employment differentials. Part of this is due to high labour force participation of natives (which by international comparison is particularly high among women) rather than to poor absolute outcomes among the foreign-born compared to other host countries. On the other hand, the Nordic model(s) are founded on high employment rates of both men and women. The differences seen in the stock of the population are a result of many cohorts experiencing difficulties in the host country labour markets. Thus, although the developments in 2015 and its aftermath have been dramatic and are close in mind, history strongly suggests that substantial challenges would have waited anyway, and will be present regardless of the future development of migration policy and flows. 
Figure 1: Number of asylum seekers, by month and country

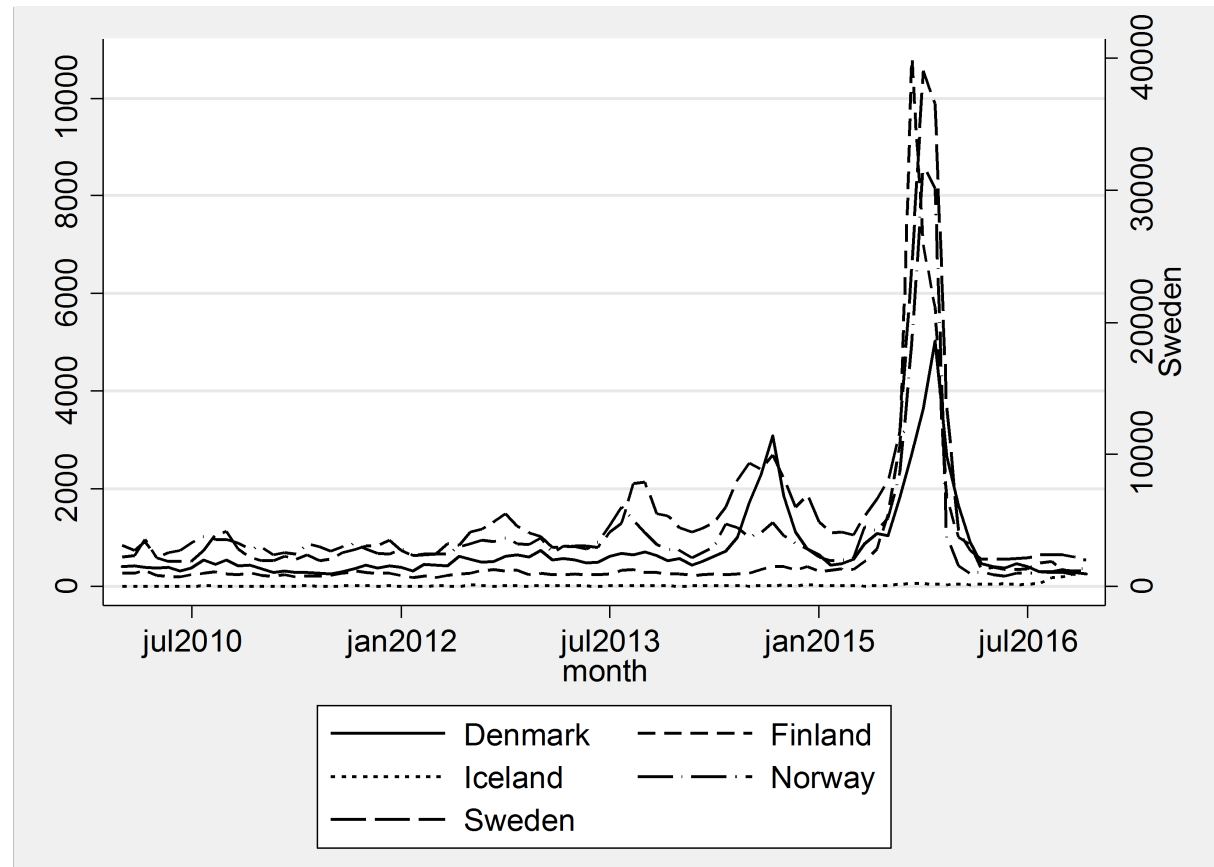

Source: Eurostat.

Societal events and processes of this kind and magnitude encompass a multitude of potential questions and perspectives on causes and consequences. The chain from international politics and actions, via the national and regional level, to the individual migrant, resident or citizen is long, multifaceted and complex. There is often little consensus on how to approach a given situation, sometimes due to ideological differences, sometimes due to a lack of knowledge on the impact of different choices. The issues concerned range from purely ethical and moral (which policies can be motivated and defended, and in which and from who's perspective) to the most practical micro-level decisions (e.g. providing housing for a family and organizing schools for the children).

This volume considers economic aspects of refugee migration. Even though this implies something of a restriction in itself, the number of potential topics is vast. There 
is of course the perhaps mostly debated micro perspective: how do refugees and other migrants fare in the labour markets of the receiving countries, and which factors and interventions influence the outcomes? What happens with labour market outcomes as the duration of the stay increases, and what does this look like in retrospect for cohorts arriving at different points in time? Are outcomes better or worse for people arriving from/to some countries than others? How can this be understood? In which industries and firms do immigrants first enter, and what do their career patterns look like? But an opposite micro perspective is also relevant - how do different types of immigration affect the outcomes and opportunities for the resident population? Such effects can be positive or negative and operate through competition for jobs and wage formation as well as through public finances.

In a longer perspective other issues appear. One factor that will be central to the long-run consequences regards the performance of immigrant children in the educational systems of the receiving countries. Also, to what extent will refugee migration affect the overall functioning of the labour market, e.g. the matching between firms and workers? Will today's recently arrived refugees and family reunification migrants be part of the answer to the demographic challenges facing societies with an aging population? How does immigration affect trade between host and source countries, and is refugee migration similar to other forms of migration in this sense?

There are thus some hard to choices to be made when selecting topics for an issue like this. Most of the international literature does not consider humanitarian migrants specifically. One reason is data limitations. Analysis requires the ability to separate different groups of migrants from each other. Data access is improving and some papers in the volume use data on the direct admission class of each immigrant. Others combine information about year of immigration and source country with official information about refugee-sending countries. By using rich and detailed longitudinal data building on the administrative registers available in the Nordic countries, we can overcome methodological challenges and fill in some gaps in the existing literature. Therefore, we have chosen to include four papers describing and analysing the labour market performance of humanitarian-related migrants in Denmark, Finland, Norway and Sweden, respectively. The papers differ somewhat in their approaches and contents, but together they give an updated and thorough picture of historical labour market and policy experiences. This hopefully provides some basis for a discussion on contemporary challenges. Next, two papers consider the educational performance of 
refugee children: one analysing the patterns and determinants of school achievements in Sweden, one studying whether changed financial support for refugee families in Denmark influenced school results. Lastly, the issue includes an analysis and discussion of the short- and long-run impact of refugee migration on public finances, based on Sweden's experiences.

Using Danish and Norwegian longitudinal administrative registry data, respectively, the papers by Schultz-Nielsen and Bratsberg, Raaum and Røed investigate the patterns of labour market integration of the different admission classes of immigrants in the host country and estimate the immigrant-native employment gap by years since migration, controlling for a wide range of individual background characteristics and the local labour market. The Norwegian analysis considers all immigrants who immigrated during 1990-2013 but distinguishes by admission class, while the Danish analysis is limited to the admission class of refugees and familyreunified with refugees who immigrated during 1997-2011. Both analyses show that for refugees and family-reunified immigrants from low-income source countries, the immigrant-native employment gap narrows fast in the first years after immigration, but after only 5-10 years the gap widens again and the rates of immigrant social insurance dependency increases. 10 years after immigration, the refugee-native employment gap in Norway is estimated to be around 22 percentage points for men and 30 percentage points for women. The Danish analysis reveals even larger employment gaps ten years after immigration for both men and women. The estimated refugee-native gaps in social dependency rates are to a large extent a mirror image of the refugee-native employment gaps.

The Norwegian analysis also shows substantial heterogeneity within admission class and between origin countries and within origin countries by educational attainment. The latter finding suggests that host country schooling is an important factor for medium and long-run labour market integration of immigrants in Norway. Interestingly, the Danish study also estimates the employment gap between refugees and low-skilled natives by years since migration. This employment gap narrows much faster than the employment gap between refugees and natives in general, suggesting that refugees and family-reunified with refugees faces similar challenges in the labour market as low-skilled natives.

Both analyses also reveal that the business cycle is a key determinant of the pace of labour market integration of male refugees. The Danish study shows that male refugees who immigrated during an economic boom have a considerably faster pace of 
labour market integration than refugees who immigrated during a downturn in the economy. Similarly, the Norwegian study shows that labour market status of refugees is very sensitive to the local unemployment rate and far more sensitive to it than natives. In view of these results, the larger male refugee-native employment gap ten years after immigration in Denmark than in Norway may at least in part be due to the higher unemployment rate in Denmark than Norway. ${ }^{1}$

Similarly to the Norwegian study by Bratsberg et al., the Finnish study by Sarvimäki and the Swedish study by Åslund, Forslund and Liljeberg analyses labour market integration of immigrants who arrived in 1990-2013/2014, using Finnish and Swedish registry data, respectively. The Finnish study focuses on immigrants from refugeesending countries, including Afghanistan, Iraq and Somalia. The Swedish study focuses on Non-Western, predominantly non-labour, immigrants. The Finnish study presents age and gender corrected estimates of the refugee-native employment gaps. As for Norway and Denmark, the gaps are initially very high but narrow somewhat during the first 10 years since immigration and vary greatly by gender and source country. After 10 years since immigration the gaps remain fairly constant.

The studies focusing on labour market outcomes also investigate earnings patterns of refugees. For example, the Danish study estimates that the earnings differential between refugees and natives is very large initially and decreases only slightly during the first ten years after immigration. Further investigation reveals that this is at least in part due to the relatively low education of refugees compared to natives. Similarly, the Finnish study estimates that ten years after immigration the average earnings of male immigrants from refugee-sending countries in Finland were only $22-38 \%$ of the average earnings of native men of the same age, depending on the source country. The Swedish study documents a general slow pace of labour market entry. Even though there is heterogeneity by country of origin and business cycle conditions, the overall impression is that cohorts perform quite similarly in the longer run. There are clear differences by gender; women have their first contacts and stable jobs later than men. The first employer contact is for many non-Western immigrants a port to a more stable position, often with the same employer. The first job is thus very important in the integration process. It is often found in small, low-earnings firms, which tended to be in

${ }^{1}$ http://ec.europa.eu/eurostat/statistics-explained/index.php/File:Unemployment_rate_2004-2015_(\%25)_new.png 
the manufacturing industry in the 1990s, but are increasingly found in the service industries.

The article by Grönqvist and Niknami considers the compulsory performance of refugee children in Sweden since the late 199os. Throughout the observation period 1997-2014, individuals who have arrived in Sweden as humanitarian migrants constituted $3-5 \%$ of the grade 9 cohorts. The authors document a substantial and in recent years widening performance gap. The average percentile ranked GPA among refugees was about 40 until 2007, and has fallen below 35 in recent years. A high fraction of particularly low-grade students drive the differences. Similar differences can be found in the upper secondary qualification rates. While over $90 \%$ of native children are qualified for upper secondary education, the fraction has been below $80 \%$ among refugees since the 1990 s and in recent years in the order of $65 \%$. High age at migration is well-known to predict poorer school outcomes. In a statistical sense, much of the increase in the gap can be explained by higher age at migration in later cohorts.

The authors then move on to investigate potential explanations to the gap. Parental socioeconomic status is strongly connected to educational performance in general. Given that education and earnings are lower among parents to refugee children it is not surprising to find that this factor can explain more than half of the gap to native students. Another potential channel for the differences is schools and neighbourhoods. Controlling for parental socioeconomic status and neighbourhood eliminates the performance gap. In other words, refugee children perform similar to native neighbours with similar parents, even though this pattern cannot be given any causal interpretation.

Given that the economic situation of the family is in general linked to the school results of the children, one could ask whether benefit levels and regulations transmit into performance among children in marginal households. This is the topic studied by Jakobsen, Kaarsen and Vasiljeva. They exploit a 2002 reform in Denmark, which substantially reduced the benefits available to newly arrived refugees. While the reform did improve labour market outcomes among those affected, the increase in earnings did not offset the reduction in benefits. The total parental income over the first three years fell by an estimated $14 \%$.

The article investigates whether the reform affected grade 9 test results, compulsory school completion and enrolment in upper secondary education. It also looks into employment and earnings of youth in the refugee cohorts considered. The empirical analysis uses the fact that there was a sharp change in the benefit system and 
compares those arriving after the reform to those subjected to the pre-reform regulations. The authors find no evidence that the reform altered the educational or early labour market outcomes among refugee children. School results are very similar among those who arrived before and after the reform. This pattern holds for a large set of outcome variables and in several robustness checks. It is possible that the zero impact is an effect of two counteracting forces: an income effect working in the negative direction and a possible positive impact from the stronger labour market situation among the parents. Another possible interpretation is that other support systems of the welfare state in this case mitigated the immediate link between parental income and child school outcomes.

The design and impact of welfare systems links to the topic of the last article in the volume: a discussion and analysis of the fiscal consequences of refugee immigration, by Ruist. He departs from a broad perspective including methodological and ethical considerations and then discusses the different factors and channels at work. Immigrants tend to be concentrated in working ages, which implies a potential for positive fiscal effects (pay more taxes and use less services compared to children and the elderly). In the opposite direction works the pervasive employment gaps and lower earnings discussed above.

According to one study discussed in the article, historical inflows of refugees and their family members to Sweden implies an annual SEK 30 billion deficit for public finances. Most of the effect comes from lower revenues rather than higher public costs. Another presented study considers the redistribution to 2005-2007 refugees and Ruist links this to the expected impact of the inflow during 2015. This calculation requires some assumptions, but points to a possible fiscal cost of SEK 20 billion in the first year, which then falls linearly by about 1.5 billion per year. The author argues that even though these costs are indeed substantial and may require priorities and choices, they are far from endangering the stability of the welfare system. Similarly, while an improvement in labour market outcomes would indeed decrease the fiscal burden (by about SEK one billion per percentage point higher employment rate), even very large employment gains would not mean a radically different fiscal situation. However, this is not to say that such gains may not be highly important in other perspectives.

Even though the 2015 experiences suggest that refugee migration may reach levels that can threaten welfare systems in the longer run, the fact that the estimated costs in the country with the highest historical inflows are moderate and in the order of $1 \%$ of GDP, signals that it is possible for countries to choose to accommodate larger numbers 
of humanitarian migrants. Had all EU15 countries matched Sweden's levels in the decade preceding the latest peak, Ruist notes, five million more individuals could have been given shelter.

The papers included in the issue show many similarities for the Nordic countries. Short- and long-term patterns of labour market integration resemble each other over time and across host countries. Even though the scale and the details of the challenges vary somewhat, the broader picture contains more similarities than differences. The results presented here clearly shows that in all countries studied, the labour market outcomes in previous cohorts of refugees and non-Western migrants in general never reach parity with natives. Substantial differences prevail and may in fact increase after an initial period of improved relative positions.

Numerous reports and commissions have discussed alternatives for policy; recent examples include Beskæftigelseministeriet (2015), Calmfors et al. (2017), NOU (2017) and Skans et al. (2017). Previous research and the fact that within different groups of migrants there is considerable heterogeneity indicate that there is not likely to be one single measure or reform that will dramatically change the situation. Rather, the literature suggests that several margins influence and can be influenced: supply, demand and matching all play a role. There is ample evidence that skills and qualifications, the design of welfare systems, labour costs, employer discrimination, networks and contacts all affect the labour market outcomes of marginal groups. There is clearly a role for active policy, even though the reviews included in this volume and otherwise suggest that we still have a lot to learn regarding policies aimed at recent migrants (see e.g. Bilgili 2015; Butschek \& Walter 2013; Martin et al. 2016; Rinne 2012). It is also important to remember that since the causes of problems are likely to differ across individuals, so should probably the solutions. To make quicker and better use of the skills of highly educated migrants is one type of challenge; to find ways to accommodate large groups of low-skill workers with little previous experience in the Nordic economies building on high productivity and high wages is quite another.

Some measures are uncontroversial in the sense that there is not much of a tradeoff given a budget restriction and sufficient knowledge; e.g. making reception systems efficient and decreasing waiting times at different stages, or choosing the supplementary education or labour market program proven to be most effective for a given individual. Other debated reforms include clearer ideological components and considerations of impacts on others; e.g. the types and level of economic support given to recent migrants (and in the longer run its consequences for universal welfare 
systems), changes in the wage structure or employment protection. In the latter case, a solid foundation of facts and evidence is even more central, since policy decisions have to weigh pros and cons of different options.

Humanitarian immigration policies are not primarily set to serve economic purposes. Yet, economic perspectives are certainly part of the debate. Our hope is that the articles included in this issue provide information for a continued discussion. But as noted above, there are several issues which have to be left for further research. One is the somewhat paradoxical challenge to square the apparent parallel races to the top (to attract high-ability immigrants) and to the bottom (to not appear as an attractive destination country for less attractive migrants), with the estimated future needs for workers in countries with aging populations. Even though we do not know what the future supply and demand for potential migrants to the Nordic region will look like, finding ways to better include groups now struggling is an important key from several perspectives. Successful educational and labour market policies will in all likelihood also have a positive influence on other potentials brought by migration and a more diverse population, e.g. regarding trade and innovation. The literature is limited, and we need a better foundation for understanding to what extent short-run easily observed costs associated with humanitarian migration can be offset by future harder-to-capture gains, and what policies can make such an outcome more likely. 


\section{Literature references}

Beskæftigelseministeriet (2015). Nye veje mod job-for borgere i udkanten af arbejdsmarkedet. Ekspertgruppen om udredning af den aktive beskæftigelsesindsats.

Bilgili, Ö. (2015). Evaluating Impact: Lessons Learned from Robust Evaluations of Labour Market Integration Policies. Working Paper, project Integration Policies: Who benefits.

Butschek, S. \& T. Walter (2013), What Active Labour Market Programmes Work for Immigrants in Europe? A Meta-Analysis of the Evaluation Literature. A Meta-Analysis of the Evaluation Literature (August 21, 2013). ZEW-Centre for European Economic Research Discussion Paper, (13-056).

Calmfors, L., P. Danielsson, A.S. Kolm, T. Pekkarinen \& P. Skedinger (2017). Arbetsmarknadsekonomisk rapport: Tudelningarna på arbetsmarknaden.

Dustmann, C., F. Fasani, T. Frattini, T., L. Minale \& U. Schönberg. (2016). On the Economics and Politics of Refugee Migration. IZA Discussion paper No. 10234.

Martín, I., A. Arcarons, J. Aumüller, P. Bevelander, H. Emilsson, S. Kalantaryan, A. Maciver, I. Mara, G. Scalettaris, A. Venturini, H. Vidovic, I. Van Der Welle, M. Windisch, R. Wolffberg, and A. Zorlu (2016) From refugees to workers: mapping labour market integration support measures for asylum-seekers and refugees in EU member states. Volume II : Literature review and country case studies.

NOU (2017) Integration og tillit. Langsiktige konsekvenser av hoy innvandring. Norges offentlige utredninger 2017:2.

Rinne, U. (2012). The evaluation of immigration policies (No. 6369). Discussion Paper series, Forschungsinstitut zur Zukunft der Arbeit (IZA).

Skans, O.N., S. Eriksson \& L. Hensvik (2017). Åtgärder för en inkluderande arbetsmarknad, SNS Konjunkturrådsrapport 2017. 


\title{
1. Immigrant labor market integration across admission classes
}

Bernt Bratsberg, Oddbjørn Raaum, and Knut Røed ${ }^{2}$

\begin{abstract}
We examine patterns of labor market integration across immigrant groups. The study draws on Norwegian longitudinal administrative data covering labor earnings and social insurance claims over a 25-year period and presents a comprehensive picture of immigrant-native employment and social insurance differentials by admission class and by years since entry. For refugees and family immigrants from low-income source countries, we uncover encouraging signs of labor market integration during an initial period upon admission, but after just 5-10 years, the integration process goes into reverse with widening immigrant-native employment differentials and rising rates of immigrant social insurance dependency. Yet, the analysis reveals substantial heterogeneity within admission class and points to an important role of host-country schooling for successful immigrant labor market integration. ${ }^{3}$
\end{abstract}

\footnotetext{
${ }^{2}$ Frisch Centre

3 We are grateful to Anna Piil Damm, Anders Forslund, and Torben Tranæs for helpful comments. We also acknowledge funding from the Ministry of Finance (project "Employment and Social Insurance among Immigrant Groups in Norway") and NORFACE (project "Globalisation, Institutions and the Welfare State"). The paper is part of the research activities of Oslo Fiscal Studies - a Centre for Public Economics, University of Oslo. Data made available by Statistics Norway have been essential for this research.
} 
- Keywords: Refugees, immigrants, employment, social insurance, integration

- JEL code: $J_{61}, \mathrm{H}_{2} O$

\subsection{Introduction}

Rising rates of immigration over the past decade have spurred debates on immigration and integration policies in many destination countries, questioning the absorptive capacity of recipient economies. In the Nordic countries, two important developments have lifted immigration and integration issues to the top of the political agenda. The first is the 2004 and 2007 enlargements of the common European labor market, which triggered a massive inflow of labor migrants from Eastern Europe. The second is the recent refugee crisis, which culminated during the autumn of 2015 with historically high levels of asylum seekers in most European countries. At the same time, family immigration has brought fundamental change to the demographic make-up of the Nordic populations.

In a world with large cross-country productivity differences, there will potentially be considerable economic gains associated with unrestricted movement of persons across national borders, as open borders allow labor to flow towards its best use (Clemens, 2011; Kennan, 2013). With the ageing of European populations, immigration has also been hailed as a possible solution to the demographic and fiscal challenges facing these countries over the coming decades (Storesletten, 2000). However, for higher immigration rates to alleviate rather than to aggravate the fiscal challenges ahead, successful integration of immigrants in the host-country labor market is crucial. In order to assess the merits of integration policies, and, more generally, the economic and fiscal consequences of increased immigration, it is necessary to examine residential decisions as well as labor market behavior and social insurance claims over the long haul. In particular, studying the labor market performance of immigrants during their very first years in the host country provides little insight into the overall economic consequences of immigration, as, for example, labor immigrants by definition will have a job whereas refugees have had little chance of obtaining employment at this stage. This observation also implies that simple cross-sectional comparisons of, say, 
employment rates between immigrants and natives may not be informative about the ultimate economic consequences of immigration. What we need is knowledge about how the labor market careers are likely to evolve over the potentially productive years spent in the host country.

In the present paper, we take advantage of population-based administrative register data, linked to detailed information of type of immigrant admission, and give a comprehensive account of the longitudinal labor market performance of the major immigrant groups that have arrived in Norway over the past 25 years. In particular, we distinguish between immigrants from the "old" and "new" EU, and, for immigrants from low-income source countries, those admitted for protection (e.g., given refugee or asylum status) and for family (re)unification, whether with an immigrant or a Norwegian reference person. Some of our findings are unsettling: For immigrants admitted for protection or family reunification, we find that the initially encouraging labor-market integration process comes to a halt already after five to seven years, for most groups at employment levels still well below those of similar natives. More surprisingly, the integration process then runs into reverse, with consistently widening immigrant-native employment differentials over time. Hence, apart from the first few years of residence, we find that the expected difference in labor market performance between immigrants and natives increases with years since migration, ceteris paribus. Our findings also contain some more encouraging results: There is substantial variation in labor market performance within origin country and admission class, and human capital investments, particularly through the Norwegian educational system, appear to make a big difference. Some immigrant groups reach employment rates that are similar to those of natives, at least over some years. Such heterogeneity in outcomes suggests that poor immigrant integration is not inevitable and that there is a genuine potential for higher and more stable employment.

Our results add to a body of empirical evidence indicating that humanitarian immigrants in Europe tend to be underrepresented in employment and/or overrepresented among claimants in social insurance programs (Husted et al., 2001; Sarvimäki, 2011, 2017; Lundborg, 2013; Bratsberg et al., 2014; Damas de Matos and Liebig, 2014; Schultz-Nielsen, 2017; Åslund et al., 2017). Recent studies using crosssectional EU labor force survey (EU-LFS) data from 2008 (Damas de Matos and Liebig, 2014; Dustmann et al., 2016) and 2014 (Dumont et al., 2016) document low employment rates among refugees in most destination countries. However, the EULFS based studies also indicate that the native-refugee employment gap in general 
declines with the length of stay in Europe, similar to findings for refugee immigrants in the United States (Borjas, 1982; Cortes, 2004). According to the 2014 EU-LFS, refugees even catch up with natives after 15 years in five of out of nine member states included with reliable data for such comparisons (Dumont et al., 2016; p. 21). Behind this average employment profile, refugee employment varies widely across destination countries. The study also points to large differentials by origin country, with Bosnian refugees being highly successful and refugees from the Middle East having significantly lower employment rates. A recent study using 2011 administrative data from Sweden finds an average employment gap to natives of 30 percentage points for humanitarian migrants (refugees) and $26 \%$ point for family immigrants (Luik et al., 2016).

To our knowledge, along with Schultz-Nielsen (2017), the present paper is the first to present a comprehensive picture of immigrant-native employment and social insurance differentials by admission class and by years since migration based on panel data. While our findings may be viewed as a bit discouraging with respect to the ability of the Norwegian labor market to utilize the productive resources of immigrants over the long haul, it is also worth emphasizing that our results indicate considerable scope for improvement. The fact that immigrants' employment rates in many cases decline after just five years of residence suggests that there exists an underutilized labor supply potential. Paired with the finding of large employment differentials linked to Norwegian schooling, we argue that there is a case for increased early human capital investments in order to improve language skills and provide marketable qualifications. In view of the inexorable rise in social insurance program participation with time in the country, we also advocate a more activity-oriented social insurance system, with focus on finding and offering suitable paid work rather than merely securing family income.

\subsection{Immigration to Norway}

Figure 1 shows annual gross inflows of immigrants to Norway over the last 26 years. Migration flows from outside the EU and OECD are split into four admission classes; work, education (a category that includes au pairs), family (re)unification, and refugee 
protection. ${ }^{4}$ The figure also distinguishes between inflows from countries that were included in the European Union following the 2004 and 2007 enlargements ("New EU") and the old EU member countries in western Europe, the Nordic countries, and other OECD countries (for simplicity grouped together as "Old EU/OECD"). The visible spikes during the 1990 s reflect waves of refugee arrivals and persons granted political asylum, the Balkans (early 1990s), and Iraq and Somalia (late 1990s). Over the last ten years, refugee arrivals have trended upwards although immigrants from the new EU countries have dominated overall inflows.

Figure 1: Immigrant (gross) inflows by admission class or major source region, 1990-2015

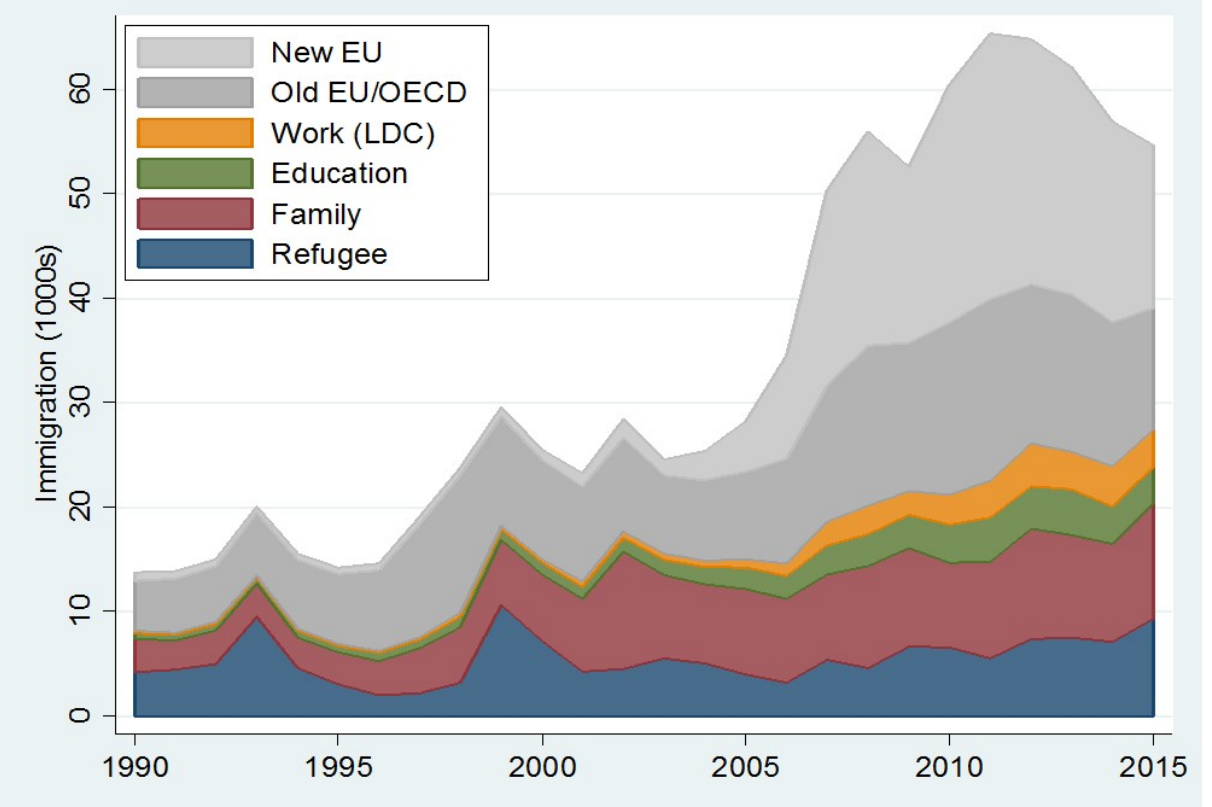

Until the EU enlargement in 2004, the vast majority of admissions from outside Europe were based on humanitarian motives and family reunification. Since the 1975 immigration freeze, work-related immigration from developing countries has been

4 Refugees include both resettlement refugees (typically through the United Nations High Commissioner for Refugees resettlement program) and those admitted following asylum application (who reached Norway by independent means before seeking asylum). 
limited as such admissions have been restricted to the "specialist" or "seasonal worker" programs, which normally require that the applicant already has a job offer at the time of application. The immigration legislation gives citizens of countries with a labor agreement with Norway the right to enter and search for a job for up to six months. Important labor agreements in recent times include those between the Nordic countries since 1954 and the European Economic Area (EEA; i.e., the European Union and member states of the European Free Trade Association) since 1994. Although Norway has stayed outside the European Union, the 2004 and 2007 eastwards enlargements of the European Union opened the Norwegian labor market to citizens of accession countries owing to Norway's EEA membership. As is evident from Figure 1 , the EU enlargements triggered massive labor migration to Norway and account for the majority of the rise in immigration since 2004 .

A considerable fraction of the immigrants leaves the country after just a few years. As illustrated in Figure 2, this is particularly the case for immigrants from the old EU and for students and work-related immigrants from developing countries. For these groups, fewer than $50 \%$ remain in the country 5 years after entry. For refugees and family migrants, the picture is very different, and around $80 \%$ appear to have settled permanently in the country. Immigrants from the new EU have a settlement pattern somewhere in between, with approximately $70 \%$ settled on a permanent basis. An implication of such differential outmigration patterns is that the long-term labor market performance of refugees and family immigrants is of particular economic and fiscal importance. 
Figure 2: Fraction of immigrants still in Norway, by admission class, arrival cohort, and years since entry

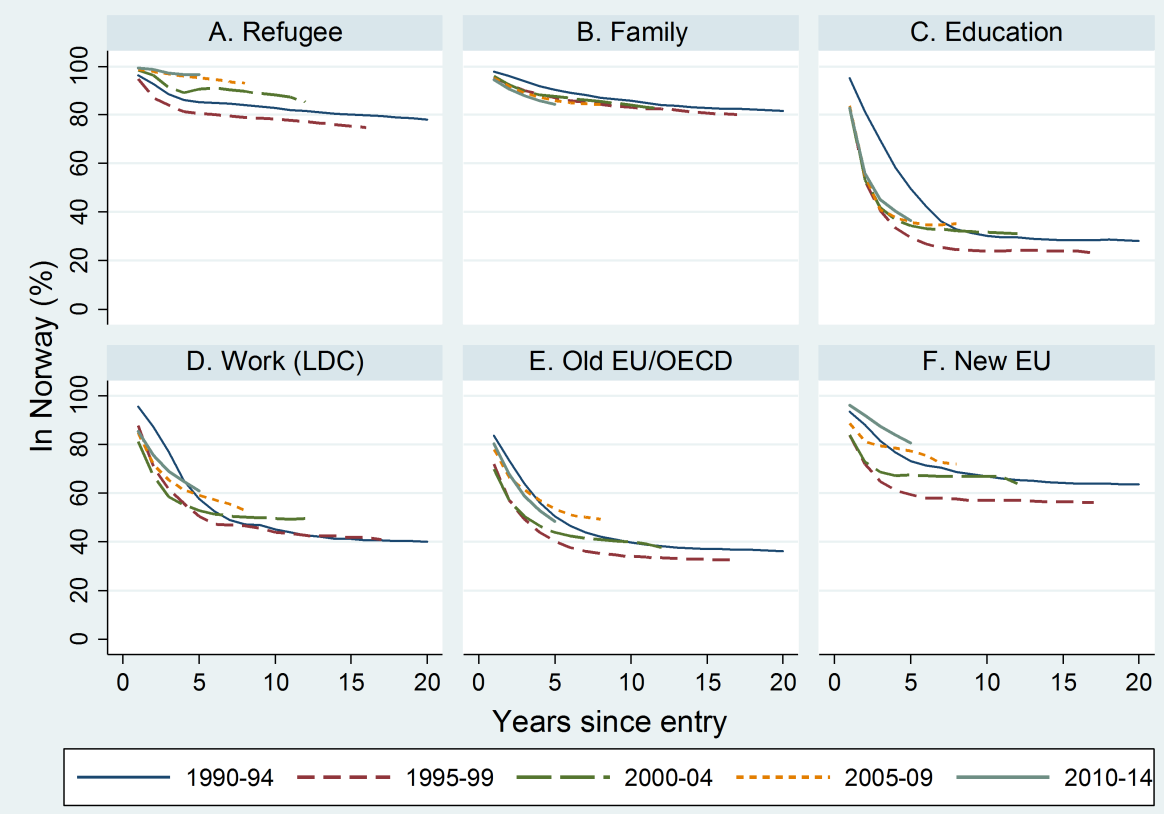

The upper panel of Figure 3 shows how the varying rates of immigrant inflows and outflows by admission class, along with other demographic trends, have changed the composition of the adult (25-66) population between 1990 and 2015. In this population segment, the overall immigrant share increased from $4.9 \%$ in 1990 to $18.7 \%$ in 2015 an increase by a factor of 3.8 over 25 years. While the share of immigrants from the old EU shows modest growth (from 2.5 to $4 \%$ of the population), the increase has been ensured by the steady rise in refugee and family immigration, and, in recent years, by the sharp increase in work-motivated immigration from the new EU. Following the 2004 EU enlargement, the fraction of immigrants in Norway has increased by a steady rate of approximately one percentage point per year. 
Figure 3: Immigrant shares of population, employment and social insurance

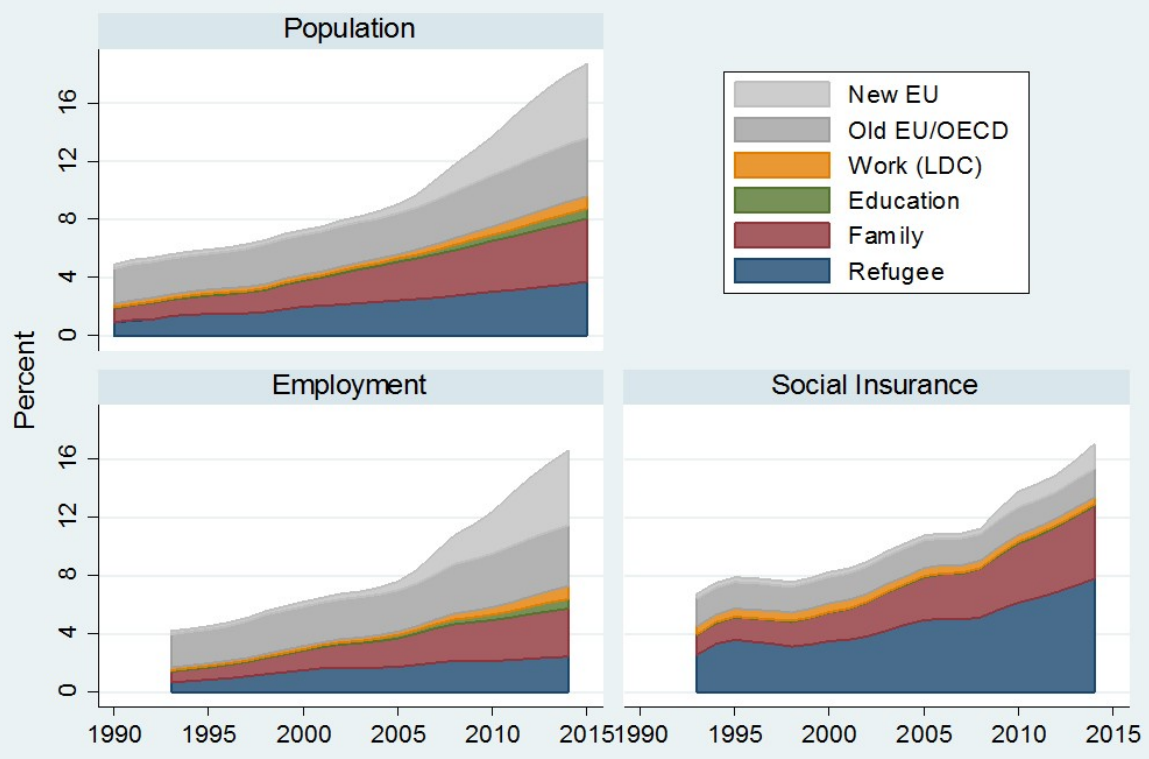

Note: Population consists of those aged 25-66 and in Norway at end of each calendar year.

While the upper panel in Figure 3 displays immigrant population shares, the lower panels show immigrant shares among persons in the states of employment and social insurance, respectively. Both here and in the subsequent analyses we define the state of "employment" in a particular year as having employment or self-employment earnings as the most important (i.e., the largest) source of income in that year. Conversely, we define the state of "social insurance" as having social insurance and/or social assistance (welfare) as the most important source of income. Based on these definitions, there is a residual category, characterized by zero earnings and zero transfers, presumably supported by their families.

In total, the immigrant share of employment has developed roughly on par with its population share, i.e., from $2.9 \%$ in 1993 to $15.8 \%$ in 2014. (Although we can study population shares through 2015 , data availably restricts the analyses of labor market and social insurance outcomes to the period between 1993 and 2014). The trends in population and employment shares varies considerably across admission classes, with 
employment shares of refugees and family immigrants lagging their growth in population shares. In a welfare state, differential employment patterns are typically mirrored by the opposite structure of social insurance. During our data window, immigrant social insurance shares increased at a slower pace than their employment shares. However, here the shares of the various immigrant groups have developed very differently, with strongly increasing shares of refugees and family immigrants and roughly constant shares of labor immigrants. In 2014, refugees and family immigrants accounted for $12.8 \%$ of social insurance claims, compared to $5.7 \%$ of employment (and $7.7 \%$ of the adult population). In contrast, the two EU groups made up $9.3 \%$ of employment (and $8.8 \%$ of the adult population) but only $3.6 \%$ of social insurance claimants. Although these patterns do illuminate the immediate (short-term) fiscal impacts of immigration at each particular point in time, they are heavily influenced by each year's immigrant composition - in terms of age, years since migration, and admission classes - and therefore provide little information about long-term consequences and impacts of fiscal sustainability. To assess the latter, we need to focus on longer-term integration in the Norwegian labor market.

\subsection{Data}

In order to study employment and social insurance claim patterns over the entire time period spent in Norway, we follow adult immigrants entering Norway from 1990 onwards for as long as the data permit, i.e., until 2014 or until exit from Norway. The analysis will be made separately for each admission class. Owing to their relatively modest number and low stay rates we leave out the admission classes made up by students and labor migrants from less developed countries (see, however, Bratsberg et al., 2010), and focus on labor migrants from new and old EU countries and on refugees and family immigrants from low-income countries. For family immigrants, we further distinguish between those married to a Norwegian born at the time of immigration and other family immigrants, presumably reunited with an immigrant reference person.

Table 1 shows some descriptive statistics for the resultant analysis samples, separately for men and women. While columns (1)-(5) report statistics for the five immigrant admission classes under study, column (6) lists the corresponding statistics for a native born comparison group consisting of a 10\% random sample of the working age native population. For immigrant men, the sample average share in employment 
(i.e., whose main source of income is work) ranges from $58 \%$ for refugees to $89 \%$ for EU immigrants, with family migrants somewhere between (around $80 \%$ ). The average shares with social insurance as the main source of income ranges from only $4 \%$ for EU immigrants to as much as $38 \%$ for refugees. The corresponding shares for native men are $87 \%$ in employment and $12 \%$ with social insurance as their main income source. For women, the average shares in employment vary from $46 \%$ for refugees to $85 \%$ for new EU immigrants, whereas the average shares in social insurance vary from $5 \%$ for new EU immigrants to $42 \%$ for refugees. The corresponding rates for native women are $80 \%$ in employment and $17 \%$ with social insurance as their main source of income. 
Table 1: Descriptive statistics, regression samples

\begin{tabular}{r|r|r|r|r|r|}
\hline Refugee & $\begin{array}{r}\text { Family to } \\
\text { immigrant }\end{array}$ & $\begin{array}{r}\text { Family to } \\
\text { Norwegian }\end{array}$ & New EU Old EU & Native \\
$(1)$ & $(2)$ & (3) & (4)
\end{tabular}

A. Men

Educational attainment

Less than secondary

Secondary

Tertiary

Attainment acquired in Norway

Less than secondary

Secondary

Tertiary

Educ in Norway below highest

Education missing

Educ imputed from occupation

Local unemployment rate

Age at entry

Years since entry

Age

Employment

Social insurance

Observations

$\begin{array}{rr}0.430 & 0.345 \\ 0.248 & 0.169 \\ 0.229 & 0.190 \\ 0.192 & 0.159 \\ 0.052 & 0.033 \\ 0.026 & 0.021 \\ & \\ 0.131 & 0.028 \\ 0.093 & 0.296 \\ 0 & 0 \\ 0.024 & 0.025 \\ 30.7 & 29.2 \\ 8.58 & 7.52 \\ 39.3 & 36.8 \\ 0.581 & 0.768 \\ 0.379 & 0.164 \\ 366,136 & 109,390\end{array}$

$\begin{array}{rrrr}0.351 & 0.215 & 0.208 & 0.393 \\ 0.202 & 0.579 & 0.302 & 0.345 \\ 0.212 & 0.169 & 0.422 & 0.257 \\ & & & \\ 0.179 & 0.014 & 0.026 & \\ 0.047 & 0.006 & 0.020 & \\ 0.030 & 0.006 & 0.037 & \\ & & & \\ 0.035 & 0.005 & 0.009 & \\ 0.236 & 0.038 & 0.068 & 0.004 \\ 0 & 0.371 & 0.188 & 0 \\ 0.024 & 0.021 & 0.023 & 0.025 \\ 28.3 & 32.8 & 31.7 & \\ 7.98 & 3.62 & 6.55 & \\ 36.3 & 36.4 & 38.3 & 43.8 \\ 0.799 & 0.883 & 0.890 & 0.871 \\ 0.149 & 0.050 & 0.046 & 0.120 \\ 75,442 & 322,823 & 402,884 & 2,093,261\end{array}$

B. Women

Educational attainment

Less than secondary

Secondary

0.487

Tertiary

Attainment acquired in Norway

\subsection{7}

$$
0.404
$$

0.143

0.377

0.238

0.298

0.157

0.475

0.181

0.174

0.288

0.417

0.223

0.227

0.174

0.053

0.181

0.033

0.134

0.062

0.558

0.295

Secondary

Tertiary

0.025

0.019

0.044

0.022

0.031

0.021

$0.042 \quad 0.068$

Educ in Norway below highest

Education missing

Educ imputed from occupation

Local unemployment rate

0.101

0.040

0.027

0.028

0.042

0.048

0.015

0.106

0.278

0.181

0.188

0.024

0.025

0.022

0.022

0.061

0.115

0.023

0.003

28.5

30.8

30.2

29.9

8.66

7.95

7.06

5.12

7.09

Age

39.4

36.4

37.9

$35 \cdot 3$

0.508

0.733

0.416

0.213

0.102

Social insurance

231,710

301,878

214,786

0.803

37.0

0.846

0.050

$191,564 \quad 291,723 \quad 1,963,026$

0.168

Note: Samples are restricted to those $25-62$ years of age, not in education, and in the country at the end of the observation year. Immigrant samples are further restricted to those 18-47 years of age at entry and who entered between 1990 and 2013. Observation period is 1993-2014. Native samples are $10 \%$ random population extracts. 
Figures 4 and 5 give a more detailed picture of employment rates and social insurance dependency by years since entry. Not surprisingly, we see that refugees have very low employment rates - and correspondingly high rates of social insurance dependency during their first years upon admission. They then catch up rather quickly during a fiveyear period, after which employment rates appear to stabilize (for women) or decline (for men). EU immigrants, on the other hand, have high employment rates to begin with, but for the new EU immigrants the employment rate tends to decline a bit after some years. For family migrants, the picture is quite different for men and women. Male family migrants have relatively high employment rates early in their stay, but the rates then decline relatively fast. Female family migrants, on the other hand, have very low employment rates to begin with, but they increase rapidly over the first five years in the country. With the exception of refugees, all the immigrant groups under study experience a quite sharp increase in their reliance on social insurance transfers over time.

Figure 4: Share of immigrants whose main source of income is work, by gender, admission class, and years since entry

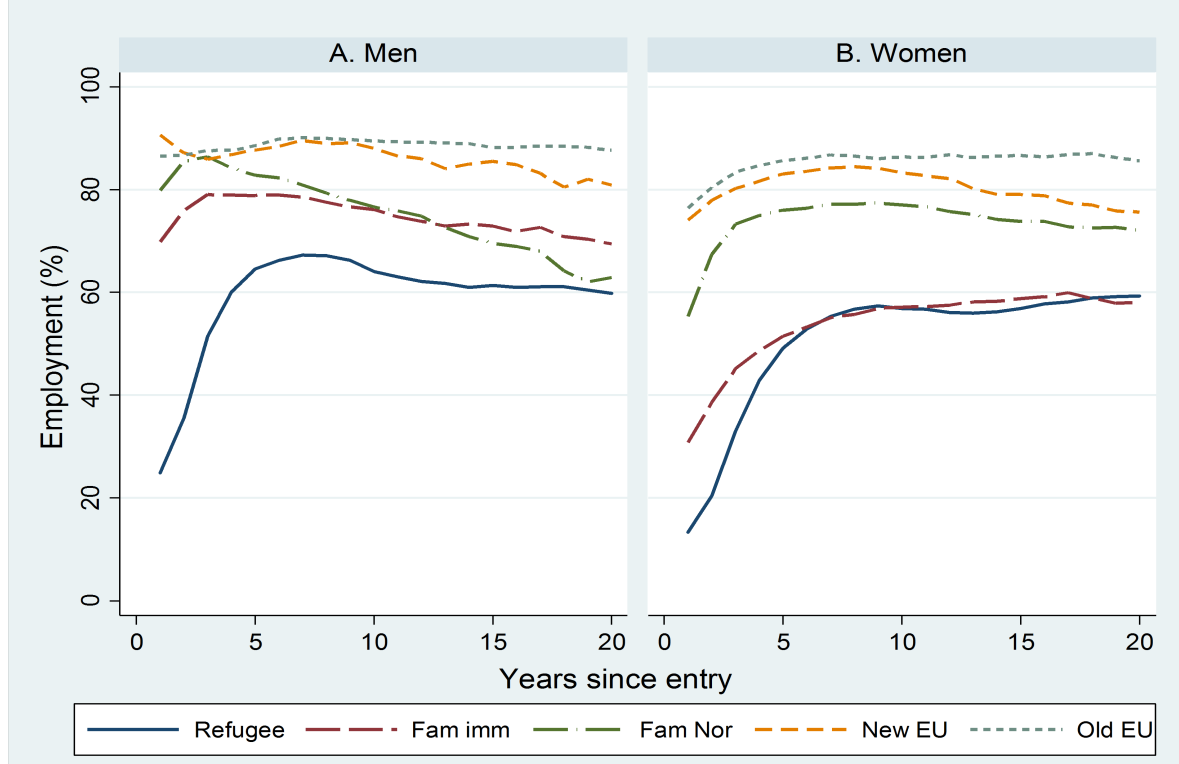

Note: Samples consist of immigrants aged 18-47 at entry and admitted between 1990 and 2013. Observation period is 1993 to 2014 . Figure entry is the mean employment rate for those aged 25-62 and in the country at the end of the calendar year. 
The descriptive statistics in Table 1 reveal substantial variation across the five immigrant admission classes in terms of age distribution, educational attainment, and years since migration during the observation window. As we return to below, they also differ with respect to origin country. There is also substantial variation in characteristics within each of the five classes, and particularly for the refugee and family immigrant groups, these differences correlate strongly with years since migration. This makes it difficult to interpret the employment and social insurance profiles displayed in Figures 4 and 5 directly, as they reflect both the impacts of sorting and causality.

Figure 5: Share of immigrants whose main source of income is social insurance transfers, by gender, admission class, and years since entry

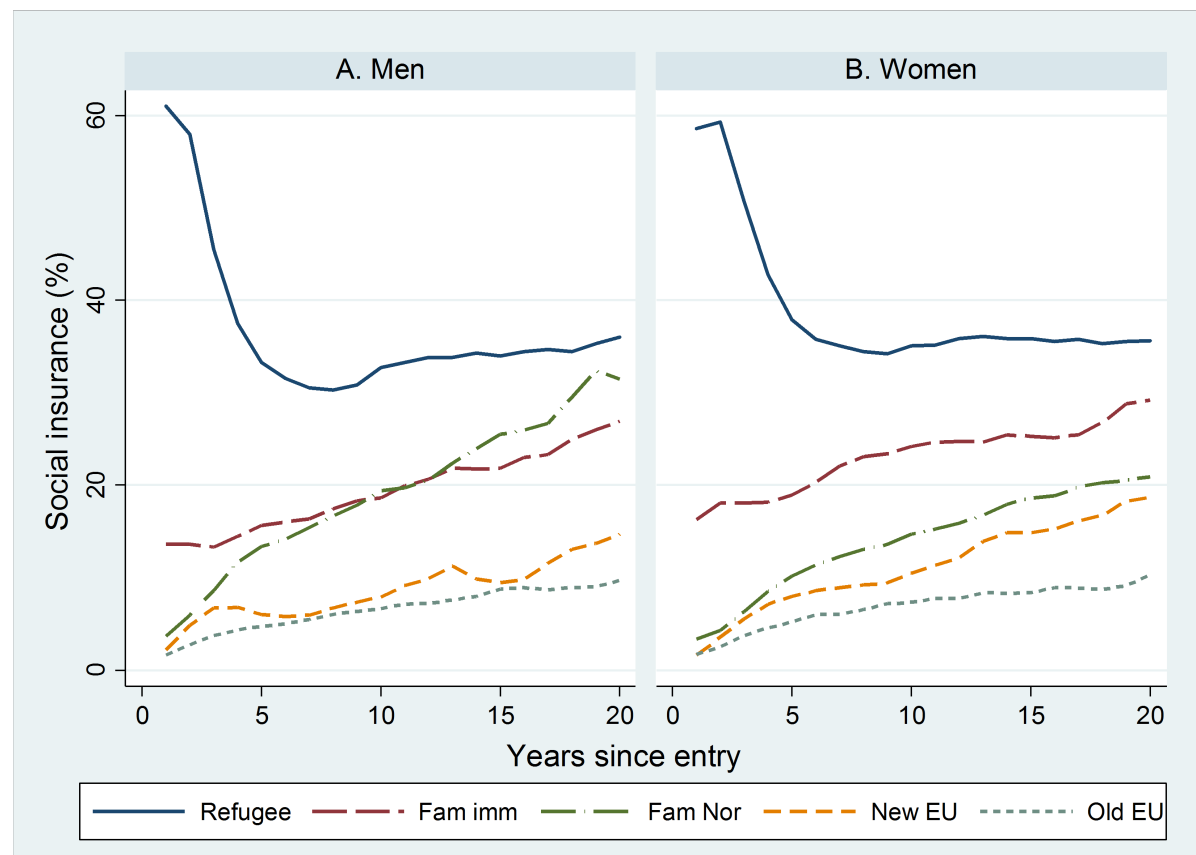

Note: Samples consist of immigrants aged 18-47 at entry and admitted between 1990 and 2013.

Observation period is 1993 to 2014 . Figure entry is the mean social insurance rate for those aged 25-62 and in the country at the end of the calendar year. 
For example, the fact that refugees from the Balkans dominated refugee arrivals during the early 1990 implies that these immigrants are strongly overrepresented among those we can follow for as much as 20 years. And, as we show below, since they turned out to have more successful labor market careers on average than other refugees, this will, if not controlled for, give the impression that employment rates rise more (or decline less) with years since migration than what we would find conditioned on country of origin. In order to establish employment social insurance dependency profiles that capture the structural impacts of years since migration, we need to control for relevant background characteristics. This will also facilitate an analysis of which characteristics - e.g., in terms of educational attainment, age at immigration, or country of origin - that are conducive for success in the Norwegian labor market.

\subsection{Empirical model}

To study the immigrant employment assimilation processes in more detail, we set up an empirical model built on the framework of Borjas (1995; 1999). Suppose the outcome (employment or social insurance as main source of income) of a person $j$ belonging to immigrant group / observed in calendar year $t$ can be represented by the following equation:

$y_{j t}^{I}=X_{j t} \phi^{I}+\sum_{a} \delta_{a}^{I} A_{a j t}+\sum_{m} \alpha_{m}^{I} Y S M_{m j t}+\sum_{c} \psi_{c}^{I} C_{c j}+\sum_{e} \theta_{e}^{I} E_{e j}+\sum_{t} \gamma_{t}^{I} \Pi_{j t}+\varepsilon_{j t}^{I}$,

while the outcome for a native is represented by

$y_{j t}^{N}=X_{j t} \phi^{N}+\sum_{a} \delta_{a}^{N} A_{a j t}+\sum_{t} \gamma_{t}^{N} \Pi_{j t}+\varepsilon_{j t}^{N}$

where $y_{j t}$ is the outcome of person $j$ in year $t_{i} X$ is a vector of socio-economic characteristics (such as educational attainment); $A$ is a vector of indicator variables for the age of the individual at the time of observation; YSM is a vector of indicator variables for the number of years the immigrant has resided in the host country; $C$ is a vector of indicators for the country of origin; $E$ is a vector of indicators for the age at the time of entry; and $\Pi$ is a vector of indicators for the calendar year. Now, looking at Equation (1) in isolation, it is clear that because the model includes indicator variables 
for age at entry, age in the year of observation, the number of years since migration, and the year of observation, we have a serious multicollinearity problem. In order to identify the model, we therefore need to impose restrictions across Equations ( 1 ) and (2); i.e., assume that some factors affect immigrants and natives the same way (Borjas, 1995; 1999). In our case, we need two such restrictions in order to identify the model, and we are going to assume that the pure cyclical variation captured by the calendar year dummies as well as the age effects are the same for immigrants and natives. Thus, we assume that $\delta_{a}^{I}=\delta_{a}^{N} \forall a$ and that $\gamma_{t}^{I}=\gamma_{t}^{N} \forall t$.

The equal year (period) effect assumption is, however, unlikely to hold as prior evidence from Norway (Barth et al., 2004), Germany and the UK (Dustmann et al., 2010), and the US (Bratsberg et al., 2006) shows that immigrant wages (and employment) are more strongly pro-cyclical than those of natives. To relax this restriction, we follow Barth et al. (2004) and include the local unemployment rate, interacted with immigrant admission class, as extra covariates (in $X$ ) in order to allow for differential responses to cyclical fluctuations. Note, however, that this does not imply that we rely exclusively on cross-sectional variation in local unemployment to identify differences between immigrants and natives in cyclical sensitivity. As the calendar year dummy variables take the same coefficient for immigrants and natives, systematic differences in the responses to nation-wide unemployment fluctuations will be absorbed by the differential responses to local unemployment.

From the set of jointly estimated coefficients from equations (1) and (2) we predict the outcome differential between immigrants and natives, for different values of years since migration (YSM). The differential for admission class $/$ and evaluated at $Y S M=m$ reads

$$
\Delta_{m}^{I}=\left(\hat{y}^{I}-\hat{y}^{N}\right)_{Y S M=m}=\bar{X}^{I}\left(\hat{\phi}^{I}-\hat{\phi}^{N}\right)+\hat{\alpha}_{m}^{I}+\sum_{c} \psi_{c}^{I} \bar{C}^{I}
$$

where $\bar{X}$ is the mean of explanatory variables in the immigrant sample and age at migration is set to its reference value of $25-29$. 


\subsection{Results}

\subsubsection{Immigrant-native employment and social insurance differentials}

Figures 6 and 7 present the estimation results regarding the developments of the immigrant-native employment and social insurance differentials by years since migration, along with their 95\% confidence intervals. The differentials given by Equation (3) are designed to capture the pure impact of years since migration, holding everything else constant. Immigrants age with additional years since immigration, but the effect of immigrant age will be captured by age at immigration and the set of age coefficients identified from the native control group. The levels of the resultant curves in Figures 6 and 7 obviously depend on the values at which everything else is being held constant, whereas the shape by construction is the same for all immigrants within an admission class.

Figure 6: Predicted employment differential between immigrants and natives, by gender, admission class, and years since entry

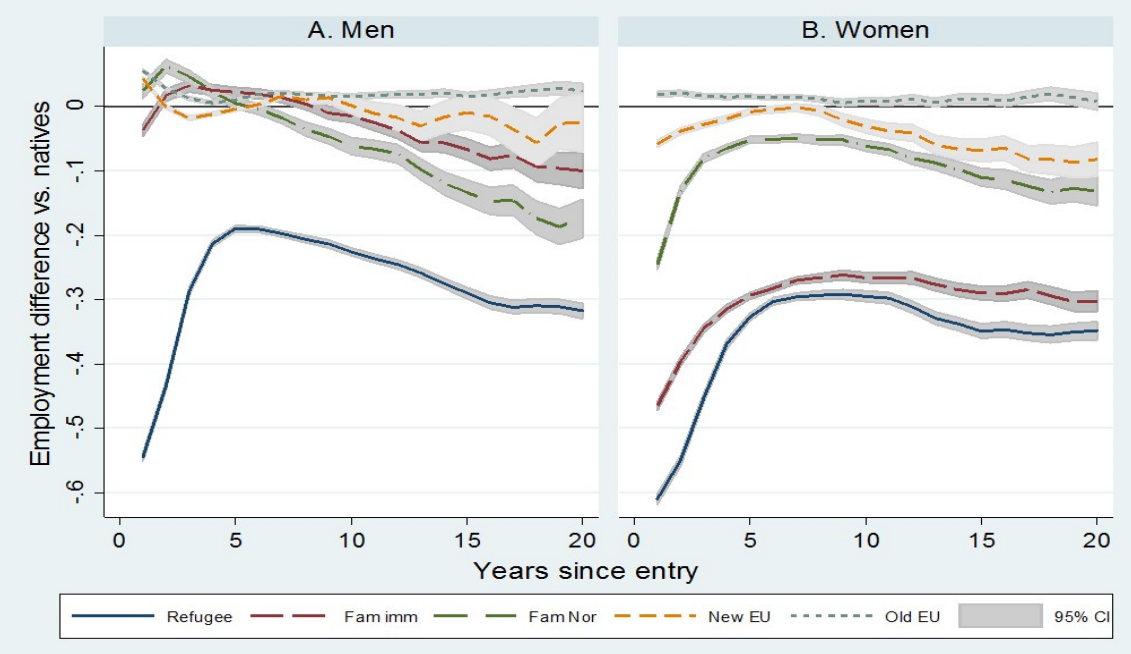

Note: Differentials are based on a regression model that controls for educational attainment, whether schooling is acquired in Norway, whether the highest attainment is from Norway, whether education information is missing, local unemployment, and age at entry-all interacted with the five admission categories. The regression further controls for age, county of residence, year of observation, and country of birth, as well as educational attainment and local unemployment interacted with native status. Differentials are evaluated at the weighted average educational attainment in each immigrant sample. See also Tables 2 and 3. 
Figure 7: Predicted social insurance differential between immigrants and natives, by gender, admission class, and years since entry

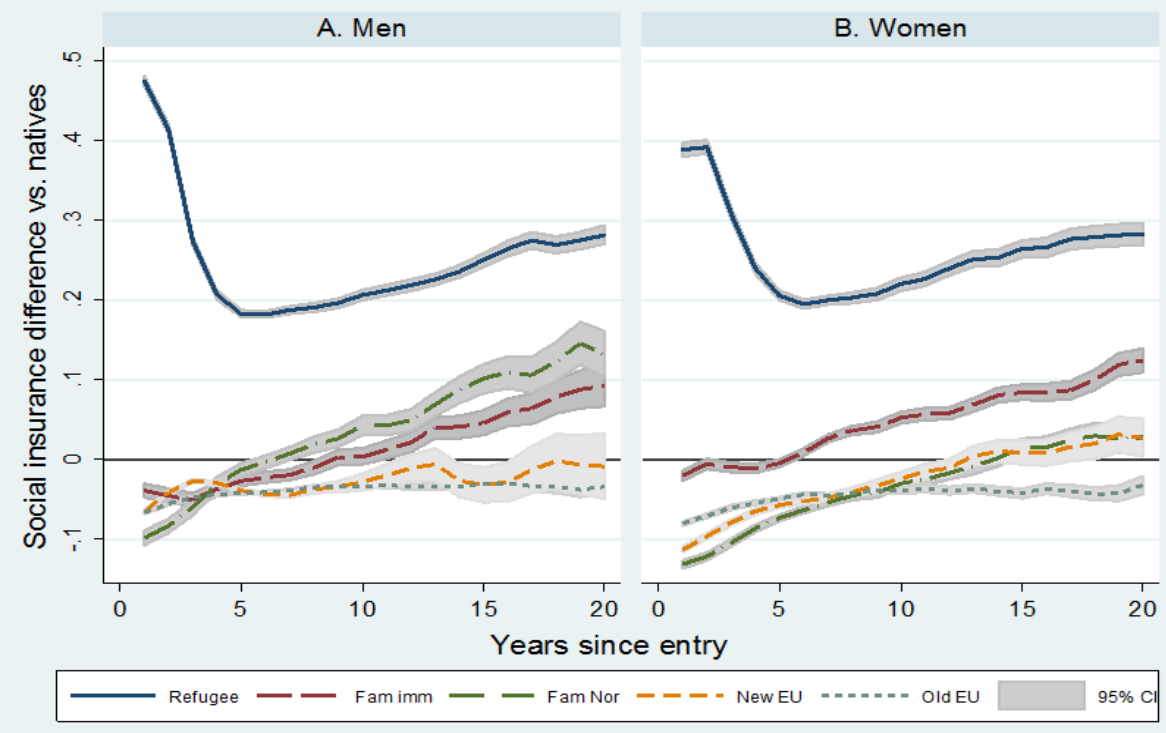

Note: Differentials are based on a regression model that controls for educational attainment, whether schooling is acquired in Norway, whether the highest attainment is from Norway, whether education information is missing, local unemployment, and age at entry - all interacted with the five admission categories. The regression further controls for age, county of residence, year of observation, and country of birth, as well as educational attainment and local unemployment interacted with native status. Differentials are evaluated at the weighted average educational attainment in each immigrant sample. See also Tables 4 and 5 .

The estimated employment and social insurance profiles deviate considerably from the descriptive patterns of Figures 4 and 5 . In particular, for immigrants from low-income source countries we now observe a much clearer decline in employment after just a few years in Norway. The profiles estimated for refugees are particularly striking. For men, we find that the native-immigrant employment gap reaches its minimum value at 20 percentage points after five to six years of residence. The gap then starts to increase quite sharply again, and reaches 30 percentage points after 15 years. This development is mirrored by a corresponding increase in social insurance dependency. For female refugees, the employment differential reaches its minimum of 30 percentage points 
after 5-9 years of residence. The subsequent decline is less dramatic than what we observe for men, but the differential stands at 35 percentage points 15 years after admission. ${ }^{5}$

Turning to the two family immigrant groups, our estimates reveal very different profiles for men and women. For male family immigrants, we generally observe an immigrant employment advantage to start with. After around five years, however, a negative employment differential builds up, and it increases faster for family immigrants with a Norwegian-born reference person than for those with an immigrant reference person. After 15 years of residence, the negative employment differentials are around 13 percentage points for the former, and 8 percentage points for the latter group. Again, these developments are mirrored by a corresponding rise in social insurance differentials. For female family immigrants, on the other hand, we estimate the employment differential to be very large during the first years in Norway. It then follows a pattern similar to that of female refugees, with rapid labor market integration during the first 5-10 years, and a moderate disintegration afterwards. As for males, there is a rather monotonous increase in social insurance differentials with years since entry (see Figure 7).

For immigrants from the old EU, the employment differential is slightly in favor of immigrants regardless of years since migration, and the social insurance differentials remain consistently negative. In other words, employment of old EU immigrants is almost indistinguishable from that of natives, and they are less likely to claim social insurance benefits. For immigrants from the new EU, a slight negative employment differential builds over time. The use of social insurance is moderate for this group, although there are some indications of a positive trend for women. It should be emphasized, however, that estimates of the long-term developments for immigrants from the new $\mathrm{EU}$ are based on a relatively small group of immigrants that migrated prior to the $2004 \mathrm{EU}$ enlargement; hence their outcomes may not be representative for those who came after the enlargement. These results should therefore be interpreted with some care.

${ }^{5}$ Bratsberg et al. (2016c) find that, conditional on employment, annual earnings of refugees do not exhibit similar declines relative to those of natives. 


\subsubsection{Heterogeneity within and between origin countries}

Even when we compare immigrants of the same age and length of stay in Norway, employment rates differ considerably across workers depending on educational attainment, age at entry, country of origin, and labor market conditions. In Tables 2 through 5 , we focus on individual heterogeneity within admission class and origin country, controlling for age and years since admission. In terms of Figure 6 and 7 , in this section we study factors that determine "the intercept" of the curves, or how the predicted immigrant-native differential varies across individuals according to their observed characteristics.

Table 2: Determinants of employment, men

\begin{tabular}{|c|c|c|c|c|c|c|}
\hline & (1) & $\begin{array}{r}\text { Family to } \\
\text { immigrant } \\
\text { (2) }\end{array}$ & $\begin{array}{r}\text { Family to } \\
\text { Norwegian } \\
\text { (3) }\end{array}$ & (4) & Old EU & $\begin{array}{r}\text { Native } \\
\text { (6) }\end{array}$ \\
\hline \multicolumn{7}{|l|}{ Educ attainment (ref=sec) } \\
\hline Less than secondary & $\begin{array}{r}-0.061 * * * \\
(0.002)\end{array}$ & $\begin{array}{r}-0.049^{* * *} \\
(0.004)\end{array}$ & $\begin{array}{r}-0.040 * * * \\
(0.004)\end{array}$ & $\begin{array}{r}-0.017^{* * *} \\
(0.001)\end{array}$ & $\begin{array}{r}-0.011 * * * \\
(0.002)\end{array}$ & $\begin{array}{r}-0.132 * * * \\
(0.000)\end{array}$ \\
\hline Tertiary & $\begin{array}{r}0.040 * * * \\
(0.002)\end{array}$ & $\begin{array}{r}0.020 * * * \\
(0.004)\end{array}$ & $\begin{array}{r}0.015^{* * *} \\
(0.004)\end{array}$ & $\begin{array}{r}0.039 * * * \\
(0.002)\end{array}$ & $\begin{array}{r}0.047^{* * *} \\
(0.001)\end{array}$ & $\begin{array}{r}0.039 * * * \\
(0.000)\end{array}$ \\
\hline \multicolumn{7}{|l|}{ Attainment acq in Norway } \\
\hline Less than secondary & $\begin{array}{r}0.056 * * * \\
(0.002)\end{array}$ & $\begin{array}{r}-0.023^{* * *} \\
(0.003)\end{array}$ & $\begin{array}{r}-0.037^{* * *} \\
(0.004)\end{array}$ & $\begin{array}{r}-0.097^{* * *} \\
(0.005)\end{array}$ & $\begin{array}{r}-0.109 * * * \\
(0.003)\end{array}$ & \\
\hline Secondary & $\begin{array}{r}0.136 * * * \\
(0.003)\end{array}$ & $\begin{array}{r}0.067^{* * *} \\
(0.006)\end{array}$ & $\begin{array}{r}0.072 * * * \\
(0.006)\end{array}$ & $\begin{array}{r}0.063^{* * *} \\
(0.008)\end{array}$ & $\begin{array}{r}0.039 * * * \\
(0.004)\end{array}$ & \\
\hline Tertiary & $\begin{array}{r}0.226 * * * \\
(0.004)\end{array}$ & $\begin{array}{r}0.101 * * * \\
(0.007)\end{array}$ & $\begin{array}{r}0.117^{* * *} \\
(0.007)\end{array}$ & $\begin{array}{r}0.007 \\
(0.008)\end{array}$ & $\begin{array}{l}0.004^{*} \\
(0.003)\end{array}$ & \\
\hline $\begin{array}{l}\text { Norwegian schooling below } \\
\text { highest attainment }\end{array}$ & $\begin{array}{r}0.042 * * * \\
(0.002)\end{array}$ & $\begin{array}{r}-0.025^{* * *} \\
(0.006)\end{array}$ & $\begin{array}{r}-0.061 * * * \\
(0.007)\end{array}$ & $\begin{array}{r}-0.135^{* * *} \\
(0.008)\end{array}$ & $\begin{array}{r}-0.102 * * * \\
(0.005)\end{array}$ & \\
\hline Local unemployment rate & $\begin{array}{r}-5.673 * * * \\
(0.070)\end{array}$ & $\begin{array}{r}-3 \cdot 311 * * * \\
(0.136)\end{array}$ & $\begin{array}{r}-4.022 * * * \\
(0.157)\end{array}$ & $\begin{array}{r}-1.839 * * * \\
(0.090)\end{array}$ & $\begin{array}{r}-0.971 * * * \\
(0.065)\end{array}$ & $\begin{array}{r}-1.164 * * * \\
(0.011)\end{array}$ \\
\hline
\end{tabular}




\begin{tabular}{|c|c|c|c|c|c|c|}
\hline & Refugee & $\begin{array}{l}\text { Family to } \\
\text { immigrant }\end{array}$ & $\begin{array}{r}\text { Family to } \\
\text { Norwegian }\end{array}$ & New EU & Old EU & Native \\
\hline & (1) & (2) & (3) & (4) & (5) & (6) \\
\hline \multicolumn{7}{|c|}{ Age at entry (ref $=25-29)$} \\
\hline $18-24$ & $\begin{array}{r}0.038 * * * \\
(0.002)\end{array}$ & $\begin{array}{r}-0.007^{* *} \\
(0.003)\end{array}$ & $\begin{array}{l}0.006 * \\
(0.003)\end{array}$ & $\begin{array}{r}-0.013^{* * *} \\
(0.002)\end{array}$ & $\begin{array}{r}-0.013^{* * *} \\
(0.002)\end{array}$ & \\
\hline $30-34$ & $\begin{array}{r}-0.034 * * * \\
(0.002)\end{array}$ & $\begin{array}{r}-0.048 * * * \\
(0.003)\end{array}$ & $\begin{array}{r}-0.015^{* * *} \\
(0.003)\end{array}$ & $\begin{array}{r}-0.005^{* * *} \\
(0.002)\end{array}$ & $\begin{array}{r}-0.009 * * * \\
(0.001)\end{array}$ & \\
\hline $35-39$ & $\begin{array}{r}-0.080 * * * \\
(0.002)\end{array}$ & $\begin{array}{r}-0.086 * * * \\
(0.003)\end{array}$ & $\begin{array}{r}-0.041 * * * \\
(0.004)\end{array}$ & $\begin{array}{r}-0.014 * * * \\
(0.002)\end{array}$ & $\begin{array}{r}-0.022 * * * \\
(0.002)\end{array}$ & \\
\hline $40-47$ & $\begin{array}{r}-0.160 * * * \\
(0.002)\end{array}$ & $\begin{array}{r}-0.149 * * * \\
(0.004)\end{array}$ & $\begin{array}{r}-0.086 * * * \\
(0.006)\end{array}$ & $\begin{array}{r}-0.010 * * * \\
(0.002)\end{array}$ & $\begin{array}{r}-0.041 * * * \\
(0.002)\end{array}$ & \\
\hline
\end{tabular}

Note: $\quad * / * * / * * *$ Statistically significant at the 10/5/1 percent level.

Standard errors, clustered within individual, are reported in parentheses. Regression samples are restricted to those 25-62 years of age, not in education, and in the country at the end of the observation year. Immigrant samples are further restricted to those 18-47 years of age at entry. Native samples are $10 \%$ random population extracts; regression is weighted to account for the $10 \%$ extract. Regressions control for years since entry and education missing - interacted with admission class - and age, observation year, county of residence, and country of birth (for a total of 449 regressors).

Tables 2 and 3 reveal that employment rates vary considerably with educational attainment. The two top rows display the estimated differentials according to attainment from abroad, with completed upper secondary school ("high school") as the reference category. Both immigrants and natives with tertiary education are more likely to be employed. The most severe employment penalty for not having completed secondary education appears for natives. In general, within admission class employment differentials across educational attainments are larger for women than for men. 
Table 3: Determinants of employment, women

\begin{tabular}{|c|c|c|c|c|c|c|}
\hline & Refugee & $\begin{array}{r}\text { Family to } \\
\text { immigrant }\end{array}$ & $\begin{array}{l}\text { Family to } \\
\text { Norwegian }\end{array}$ & New EU & Old EU & Native \\
\hline & (1) & (2) & (3) & (4) & (5) & (6) \\
\hline \multicolumn{7}{|l|}{ Educ attainment (ref=sec) } \\
\hline Less than secondary & $\begin{array}{r}-0.092 * * * \\
(0.003)\end{array}$ & $\begin{array}{r}-0.083^{* * *} \\
(0.003)\end{array}$ & $\begin{array}{r}-0.019 * * * \\
(0.003)\end{array}$ & $\begin{array}{r}-0.001 \\
(0.003)\end{array}$ & $\begin{array}{r}-0.055^{* * *} \\
(0.003)\end{array}$ & $\begin{array}{r}-0.157^{* * *} \\
(0.000)\end{array}$ \\
\hline Tertiary & $\begin{array}{r}0.094 * * * \\
(0.003)\end{array}$ & $\begin{array}{r}0.032 * * * \\
(0.003)\end{array}$ & $\begin{array}{r}0.045^{* * *} \\
(0.002)\end{array}$ & $\begin{array}{r}0.044^{* * *} \\
(0.002)\end{array}$ & $\begin{array}{r}0.042 * * * \\
(0.002)\end{array}$ & $\begin{array}{r}0.063^{* * *} \\
(0.000)\end{array}$ \\
\hline \multicolumn{7}{|l|}{ Attainment acq in Norway } \\
\hline Less than secondary & $\begin{array}{r}0.154^{* * *} \\
(0.002)\end{array}$ & $\begin{array}{r}0.144^{* * *} \\
(0.002)\end{array}$ & $\begin{array}{r}0.048 * * * \\
(0.003)\end{array}$ & $\begin{array}{r}-0.026 * * * \\
(0.004)\end{array}$ & $\begin{array}{r}-0.051 * * * \\
(0.004)\end{array}$ & \\
\hline Secondary & $\begin{array}{r}0.273^{* * *} \\
(0.004)\end{array}$ & $\begin{array}{r}0.212 * * * \\
(0.004)\end{array}$ & $\begin{array}{r}0.153^{* * *} \\
(0.005)\end{array}$ & $\begin{array}{r}0.061 * * * \\
(0.006)\end{array}$ & $\begin{array}{r}0.016 * * * \\
(0.05)\end{array}$ & \\
\hline Tertiary & $\begin{array}{r}0.259 * * * \\
(0.006)\end{array}$ & $\begin{array}{r}0.258 * * * \\
(0.005)\end{array}$ & $\begin{array}{r}0.167^{* * *} \\
(0.005)\end{array}$ & $\begin{array}{r}0.088 * * * \\
(0.005)\end{array}$ & $\begin{array}{r}0.021 * * * \\
(0.003)\end{array}$ & \\
\hline $\begin{array}{l}\text { Norwegian schooling below } \\
\text { highest attainment }\end{array}$ & $\begin{array}{r}0.094 * * * \\
(0.003)\end{array}$ & $\begin{array}{r}0.093^{* * *} \\
(0.004)\end{array}$ & $\begin{array}{r}0.039 * * * \\
(0.004)\end{array}$ & $\begin{array}{r}-0.022 * * * \\
(0.005)\end{array}$ & $\begin{array}{r}-0.039 * * * \\
(0.006)\end{array}$ & \\
\hline Local unemployment rate & $\begin{array}{r}-4.801 * * * \\
(0.102)\end{array}$ & $\begin{array}{r}-3.994^{* * *} \\
(0.092)\end{array}$ & $\begin{array}{r}-3.657^{* * *} \\
(0.104)\end{array}$ & $\begin{array}{r}-3.206 * * \\
(0.123)\end{array}$ & $\begin{array}{r}-1.454^{* *} \\
(0.085)\end{array}$ & $\begin{array}{r}-1.671 * * * \\
(0.014)\end{array}$ \\
\hline \multicolumn{7}{|l|}{ Age at entry $(r e f=25-29)$} \\
\hline $18-24$ & $\begin{array}{r}-0.003 \\
(0.002)\end{array}$ & $\begin{array}{r}0.035^{* * *} \\
(0.002)\end{array}$ & $\begin{array}{l}0.005^{*} \\
(0.002)\end{array}$ & $\begin{array}{r}-0.003 \\
(0.002)\end{array}$ & $\begin{array}{r}-0.011 * * * \\
(0.002)\end{array}$ & \\
\hline $30-34$ & $\begin{array}{r}-0.025^{* * *} \\
(0.002)\end{array}$ & $\begin{array}{r}-0.028 * * * \\
(0.002)\end{array}$ & $\begin{array}{r}-0.013^{* * *} \\
(0.002)\end{array}$ & $\begin{array}{r}-0.031 * * * \\
(0.002)\end{array}$ & $\begin{array}{r}-0.039 * * * \\
(0.002)\end{array}$ & \\
\hline $35-39$ & $\begin{array}{r}-0.053^{* * *} \\
(0.003)\end{array}$ & $\begin{array}{r}-0.049 * * * \\
(0.002)\end{array}$ & $\begin{array}{r}-0.028 * * * \\
(0.003)\end{array}$ & $\begin{array}{r}-0.020 * * * \\
(0.003)\end{array}$ & $\begin{array}{r}-0.064 * * * \\
(0.002)\end{array}$ & \\
\hline $40-47$ & $\begin{array}{r}-0.119 * * * \\
(0.003)\end{array}$ & $\begin{array}{r}-0.066 * * * \\
(0.003)\end{array}$ & $\begin{array}{r}-0.014^{* *} \\
(0.003)\end{array}$ & $\begin{array}{r}-0.007^{* *} \\
(0.003)\end{array}$ & $\begin{array}{r}-0.067 * * * \\
(0.002)\end{array}$ & \\
\hline
\end{tabular}

Note: $\quad * * * / * * *$ Statistically significant at the $10 / 5 / 1$ percent level.

Standard errors, clustered within individual, are reported in parentheses. See also note to Table 2.

The empirical model allows for additional differentials among immigrants when schooling is acquired in Norway. Rows three to five show the additional (interaction) coefficient when the highest attainment is from the Norwegian educational system. In Table 2, male refugees with upper secondary school from Norway have an average employment rate that is 13.6 percentage points higher than those with similar attainment from abroad. This differential is very large (27.3 percentage points) for women, see Table 3. For both genders, Norwegian education is associated with significantly higher employment rates across all admission classes, unless the attainment is basic (below completed upper secondary school). While male refugees 
and all female immigrants from LDC countries seem to gain from Norwegian schooling even below secondary education, other immigrant groups with basic Norwegian schooling have lower employment rates than their fellow nationals who did not acquire education in Norway. A similar pattern appears for immigrants who have some education from Norway, but at a level below the pre-migration attainment.

This study cannot determine whether differentials across educational attainment reflect causal effects of schooling or sorting on unobserved characteristics. For the admission classes under study (recall that we exclude foreign students), acquisition of additional schooling in Norway is likely to be driven by factors that generate both positive and negative selection in terms of employment prospects. While school entry can be triggered by negative employment shocks or labor market barriers, immigrants with high labor market attachment will gain more in terms of improved job careers from additional human capital investments.

The state of the labor market affects employment rates of all six groups studied. When the municipal unemployment rate (in percent of the population) increases by one percentage point, the employment rate of male natives drops by a similar magnitude (1.16 percentage point). Except for western Europeans, immigrant employment rates are far more sensitive to labor market conditions. The employment rate of male refugees falls by more than five percentage points when the overall local unemployment rate increases by one. Similar patterns appear for women, see Table 3. The greater business cycle sensitivity of refugee employment may reflect a more precarious attachment to the labor market, with more marginal and less secure jobs. Moreover, given that the last-in-firstout principle largely governs downsizing processes in Norway, immigrant employees (who tend to have shorter than average tenure) are typically harder hit by adverse employer shocks and reorganization processes. ${ }^{6}$

Immigrants differ widely in age at the time of admission. Young immigrants will have a longer time horizon for host country human capital investments and bring short foreign experiences from both within and outside the labor market. We find significant heterogeneity according to age at arrival for refugees and family immigrants from lowincome countries; see Tables 2 and 3, columns (1)-(3). Immigrants arriving after they turn thirty seem to have much lower employment rates, conditional on age and years

\footnotetext{
${ }^{6}$ Last-in-first-out is stated as a guiding downsizing principle in the "Basic Agreement" (Hovedavtalen) between the major employer and employee associations in Norway. According to the Working Environment Act (Arbeidsmiljøloven), the selection of layoffs during downsizing processes should be justifiable, with short tenure often referred to as a valid criterion.
} 
since entry. The largest "penalty" appears for male refugees arriving in their forties. For immigrants from (old and new) EU countries, there is less age at immigration heterogeneity in employment.

Table 4: Determinants of social insurance, men

\begin{tabular}{|c|c|c|c|c|c|c|}
\hline & Refugee & $\begin{array}{r}\text { Family to } \\
\text { immigrant }\end{array}$ & $\begin{array}{l}\text { Family to } \\
\text { Norwegian }\end{array}$ & New EU & Old EU & Native \\
\hline & (1) & (2) & (3) & (4) & (5) & (6) \\
\hline \multicolumn{7}{|l|}{ Educ attainment (ref=sec) } \\
\hline Less than secondary & $\begin{array}{r}0.063^{* * *} \\
(0.002)\end{array}$ & $\begin{array}{r}0.053^{* * *} \\
(0.003)\end{array}$ & $\begin{array}{r}0.024^{* * *} \\
(0.004)\end{array}$ & $\begin{array}{r}0.011 * * * \\
(0.001)\end{array}$ & $\begin{array}{r}0.023^{* * *} \\
(0.001)\end{array}$ & $\begin{array}{r}0.130 * * * \\
(0.000)\end{array}$ \\
\hline Tertiary & $\begin{array}{r}-0.042 * * * \\
(0.002)\end{array}$ & $\begin{array}{r}-0.028 * * * \\
(0.003)\end{array}$ & $\begin{array}{r}-0.026 * * * \\
(0.004)\end{array}$ & $\begin{array}{r}-0.010 * * * \\
(0.002)\end{array}$ & $\begin{array}{r}-0.025^{* * *} \\
(0.001)\end{array}$ & $\begin{array}{r}-0.041 * * * \\
(0.000)\end{array}$ \\
\hline \multicolumn{7}{|l|}{ Attainment acq in Norway } \\
\hline Less than secondary & $\begin{array}{r}-0.051 * * * \\
(0.002)\end{array}$ & $\begin{array}{r}0.017^{* * *} \\
(0.003)\end{array}$ & $\begin{array}{r}0.048 * * * \\
(0.004)\end{array}$ & $\begin{array}{r}0.110 * * * \\
(0.005)\end{array}$ & $\begin{array}{r}0.114^{* * *} \\
(0.003)\end{array}$ & \\
\hline Secondary & $\begin{array}{r}-0.127^{* * *} \\
(0.003)\end{array}$ & $\begin{array}{r}-0.070 * * * \\
(0.006)\end{array}$ & $\begin{array}{r}-0.060 * * * \\
(0.006)\end{array}$ & $\begin{array}{r}-0.026 * * * \\
(0.007)\end{array}$ & $\begin{array}{r}-0.013^{* * *} \\
(0.004)\end{array}$ & \\
\hline Tertiary & $\begin{array}{r}-0.224 * * * \\
(0.004)\end{array}$ & $\begin{array}{r}-0.091 * * * \\
(0.007)\end{array}$ & $\begin{array}{r}-0.093^{* * *} \\
(0.007)\end{array}$ & $\begin{array}{r}-0.029 * * * \\
(0.008)\end{array}$ & $\begin{array}{r}-0.005^{*} \\
(0.003)\end{array}$ & \\
\hline $\begin{array}{l}\text { Norwegian schooling below } \\
\text { highest attainment }\end{array}$ & $\begin{array}{r}-0.033^{* * *} \\
(0.002)\end{array}$ & $\begin{array}{r}0.028 * * * \\
(0.006)\end{array}$ & $\begin{array}{r}0.055^{* * *} \\
(0.006)\end{array}$ & $\begin{array}{r}0.146 * * * \\
(0.008)\end{array}$ & $\begin{array}{r}0.105^{* * *} \\
(0.005)\end{array}$ & \\
\hline Local unemployment rate & $\begin{array}{r}4.488 * * * \\
(0.067)\end{array}$ & $\begin{array}{r}2.302 * * * \\
(0.131)\end{array}$ & $\begin{array}{r}3.040 * * * \\
(0.152)\end{array}$ & $\begin{array}{r}1.011 * * * \\
(0.086)\end{array}$ & $\begin{array}{r}0.742 * * * \\
(0.062)\end{array}$ & $\begin{array}{r}1.162 * * * \\
(0.011)\end{array}$ \\
\hline \multicolumn{7}{|l|}{ Age at entry (ref=25-29) } \\
\hline $18-24$ & $\begin{array}{r}-0.044^{* * *} \\
(0.002)\end{array}$ & $\begin{array}{r}0.003 \\
(0.004)\end{array}$ & $\begin{array}{c}-0.006 * \\
(0.003)\end{array}$ & $\begin{array}{r}0.001 \\
(0.002)\end{array}$ & $\begin{array}{r}-0.006 * * * \\
(0.002)\end{array}$ & \\
\hline $30-34$ & $\begin{array}{r}0.035^{* * *} \\
(0.001)\end{array}$ & $\begin{array}{r}0.034^{* * *} \\
(0.003)\end{array}$ & $\begin{array}{r}0.007^{* *} \\
(0.003)\end{array}$ & $\begin{array}{r}0.002 \\
(0.002)\end{array}$ & $\begin{array}{r}0.011 * * * \\
(0.001)\end{array}$ & \\
\hline $35-39$ & $\begin{array}{r}0.083^{* * *} \\
(0.002)\end{array}$ & $\begin{array}{r}0.063^{* * *} \\
(0.003)\end{array}$ & $\begin{array}{r}0.020 * * * \\
(0.004)\end{array}$ & $\begin{array}{r}0.006 * * \\
(0.002)\end{array}$ & $\begin{array}{r}0.019 * * * \\
(0.002)\end{array}$ & \\
\hline $40-47$ & $\begin{array}{r}0.151 * * * \\
(0.002)\end{array}$ & $\begin{array}{r}0.091 * * * \\
(0.003)\end{array}$ & $\begin{array}{r}0.005 \\
(0.006)\end{array}$ & $\begin{array}{r}0.002 \\
(0.002)\end{array}$ & $\begin{array}{r}0.019 * * * \\
(0.002)\end{array}$ & \\
\hline
\end{tabular}

Note: $\quad * / * * / * * *$ Statistically significant at the $10 / 5 / 1$ percent level.

Standard errors, clustered within individual, are reported in parentheses. See also note to Table 2.

Individual characteristics of immigrants also influence the probability of receiving social insurance. Among men, nearly all non-employed receive social insurance and the differentials in Table 4 are basically similar to those in Table 2, but with the opposite sign. For female family immigrants, we uncover some cases where short schooling from Norway is associated with higher rates of both employment and social insurance. Local 
labor market conditions are less important for social insurance claims among women than among men.

Table 5: Determinants of social insurance, women

\begin{tabular}{|c|c|c|c|c|c|c|}
\hline & Refugee & $\begin{array}{r}\text { Family to } \\
\text { immigrant }\end{array}$ & $\begin{array}{r}\text { Family to } \\
\text { Norwegian }\end{array}$ & New EU & Old EU & Native \\
\hline & (1) & (2) & (3) & (4) & (5) & (6) \\
\hline \multicolumn{7}{|l|}{ Educ attainment (ref=sec) } \\
\hline Less than secondary & $\begin{array}{r}0.082 * * * \\
(0.002)\end{array}$ & $\begin{array}{r}0.037^{* * *} \\
(0.002)\end{array}$ & $\begin{array}{r}0.008 * * * \\
(0.003)\end{array}$ & $\begin{array}{r}0.015^{* * *} \\
(0.003)\end{array}$ & $\begin{array}{r}0.043^{* * *}(0.002)\end{array}$ & $\begin{array}{r}0.146 * * * \\
(0.000)\end{array}$ \\
\hline Tertiary & $\begin{array}{r}-0.055^{* * *} \\
(0.003)\end{array}$ & $\begin{array}{r}-0.038 * * * \\
(0.003)\end{array}$ & $\begin{array}{r}-0.030 * * * \\
(0.003)\end{array}$ & $\begin{array}{r}-0.018 * * * \\
(0.002)\end{array}$ & $\begin{array}{r}-0.021 * * * \\
(0.002)\end{array}$ & $\begin{array}{r}-0.055^{* * *} \\
(0.000)\end{array}$ \\
\hline \multicolumn{7}{|l|}{ Attainment acq in Norway } \\
\hline Less than secondary & $\begin{array}{r}-0.088 * * * \\
(0.002)\end{array}$ & $\begin{array}{r}-0.009 * * * \\
(0.002)\end{array}$ & $\begin{array}{r}0.022 * * * \\
(0.003)\end{array}$ & $\begin{array}{r}0.042 * * * \\
(0.004)\end{array}$ & $\begin{array}{r}0.072 * * * \\
(0.004)\end{array}$ & \\
\hline Secondary & $\begin{array}{r}-0.213^{* * *} \\
(0.004)\end{array}$ & $\begin{array}{r}-0.108 * * * \\
(0.004)\end{array}$ & $\begin{array}{r}-0.076 * * * \\
(0.004)\end{array}$ & $\begin{array}{l}-0.010 * \\
(0.006)\end{array}$ & $\begin{array}{r}0.010 * * \\
(0.005)\end{array}$ & \\
\hline Tertiary & $\begin{array}{r}-0.224 * * * \\
(0.005)\end{array}$ & $\begin{array}{r}-0.128 * * * \\
(0.005)\end{array}$ & $\begin{array}{r}-0.091 * * * \\
(0.005)\end{array}$ & $\begin{array}{r}-0.057^{* * *} \\
(0.005)\end{array}$ & $\begin{array}{l}-0.005^{*} \\
(0.003)\end{array}$ & \\
\hline $\begin{array}{l}\text { Norwegian schooling below } \\
\text { highest attainment }\end{array}$ & $\begin{array}{r}-0.050 * * * \\
(0.003)\end{array}$ & $\begin{array}{r}0.008 * * \\
(0.004)\end{array}$ & $\begin{array}{r}0.015^{* * *} \\
(0.004)\end{array}$ & $\begin{array}{r}0.047^{* * *} \\
(0.005)\end{array}$ & $\begin{array}{r}0.063^{* * *} \\
(0.006)\end{array}$ & \\
\hline Local unemployment rate & $\begin{array}{r}0.111 \\
(0.095)\end{array}$ & $\begin{array}{r}0.768 * * * \\
(0.087)\end{array}$ & $\begin{array}{r}1.825^{* * *} \\
(0.098)\end{array}$ & $\begin{array}{r}1.158 * * * \\
(0.115)\end{array}$ & $\begin{array}{l}1.103^{* *} \\
(0.080)\end{array}$ & $\begin{array}{r}1.403^{* * *} \\
(0.013)\end{array}$ \\
\hline \multicolumn{7}{|l|}{ Age at entry (ref=25-29) } \\
\hline $18-24$ & $\begin{array}{r}-0.015^{* * *} \\
(0.002)\end{array}$ & $\begin{array}{r}-0.022 * * * \\
(0.002)\end{array}$ & $\begin{array}{r}0.000 \\
(0.002)\end{array}$ & $\begin{array}{r}-0.001 \\
(0.002)\end{array}$ & $\begin{array}{r}-0.007^{* * *} \\
(0.002)\end{array}$ & \\
\hline $30-34$ & $\begin{array}{r}0.028 * * * \\
(0.002)\end{array}$ & $\begin{array}{r}0.026 * * * \\
(0.002)\end{array}$ & $\begin{array}{r}0.014^{* * *} \\
(0.002)\end{array}$ & $\begin{array}{r}0.014 * * * \\
(0.002)\end{array}$ & $\begin{array}{r}0.014 * * * \\
(0.002)\end{array}$ & \\
\hline $35-39$ & $\begin{array}{r}0.055^{* * *} \\
(0.002)\end{array}$ & $\begin{array}{r}0.059 * * * \\
(0.002)\end{array}$ & $\begin{array}{r}0.018 * * * \\
(0.003)\end{array}$ & $\begin{array}{r}0.018 * * * \\
(0.002)\end{array}$ & $\begin{array}{r}0.018 * * * \\
(0.002)\end{array}$ & \\
\hline $40-47$ & $\begin{array}{r}0.101 * * * \\
(0.002)\end{array}$ & $\begin{array}{r}0.056 * * * \\
(0.003)\end{array}$ & $\begin{array}{r}0.021 * * \\
(0.003)\end{array}$ & $\begin{array}{r}0.021 * * * \\
(0.003)\end{array}$ & $\begin{array}{r}0.014 * * * \\
(0.002)\end{array}$ & \\
\hline
\end{tabular}

Note: $\quad * / * * / * * *$ Statistically significant at the 10/5/1 percent level.

Standard errors, clustered within individual, are reported in parentheses. See also note to Table 2.

Destination country outcomes tend to differ significantly across individuals from various origin countries. These differentials may reflect a multitude of factors such as culture, tradition, language distance, past political/military conflicts, and transferability of human capital acquired in the home-country labor market or educational system, in turn influenced by school quality. Among refugees, the three largest origin countries in our samples are Bosnia, Iraq, and Somalia. Table 6 shows large employment and social insurance differentials across these source countries, with reported coefficients 
interpreted as average differences across origin countries relative to the mean overall outcome of the group of refugees. All coefficients are from the regression model and hold educational attainment, age, years since entry, age at immigration, county of residence and local labor market conditions constant. As the table shows, refugees from Bosnia do well in the Norwegian labor market, with employment rates 11.1 (men) and 16.0 (women) percentage points above the gender-specific average for refugees. The employment difference between refugees from Bosnia and Somalia is fully $\mathbf{2 2 . 2}$ percentage points for men and 37.7 points for women. Other male differentials are smaller, typically plus/minus 5 to 8 percentage points, with men from Afghanistan and Kosovo also having employment rates above the mean. Among female refugees from the seven major source countries include in the table, only Bosnians have employment rates significantly above the average among female refugees.

Table 6: Country of birth effects, main source countries in refugee samples

\begin{tabular}{|c|c|c|c|c|c|c|}
\hline & \multicolumn{3}{|c|}{ Men } & \multicolumn{3}{|c|}{ Women } \\
\hline & $\begin{array}{r}\text { Percent of } \\
\text { sample } \\
\text { (1) }\end{array}$ & $\begin{array}{r}\text { Employ- } \\
\text { ment } \\
(2)\end{array}$ & $\begin{array}{r}\begin{array}{r}\text { Social } \\
\text { insurance }\end{array} \\
\text { (3) }\end{array}$ & $\begin{array}{r}\text { Percent of } \\
\text { sample } \\
(4)\end{array}$ & $\begin{array}{r}\text { Employ- } \\
\text { ment } \\
(5)\end{array}$ & $\begin{array}{r}\text { Social } \\
\text { insurance } \\
\text { (6) }\end{array}$ \\
\hline Afghanistan & 0.051 & $\begin{array}{r}0.078 * * * \\
(0.009)\end{array}$ & $\begin{array}{r}-0.055^{* * *} \\
(0.009)\end{array}$ & 0.033 & $\begin{array}{r}-0.115^{* * *} \\
(0.014)\end{array}$ & $\begin{array}{r}0.112 * * * \\
(0.014)\end{array}$ \\
\hline Bosnia & 0.147 & $\begin{array}{r}0.111 * * * \\
(0.008)\end{array}$ & $\begin{array}{r}-0.099 * * * \\
(0.007)\end{array}$ & 0.225 & $\begin{array}{r}0.160 * * * \\
(0.009)\end{array}$ & $\begin{array}{r}-0.165^{* * *} \\
(0.009)\end{array}$ \\
\hline Eritrea & 0.031 & $\begin{array}{r}-0.052 * * * \\
(0.010)\end{array}$ & $\begin{array}{r}0.053^{* * *} \\
(0.010)\end{array}$ & 0.044 & $\begin{array}{l}-0.006 \\
(0.013)\end{array}$ & $\begin{array}{r}0.127^{* * *} \\
(0.012)\end{array}$ \\
\hline Iran & 0.081 & $\begin{array}{r}-0.044^{* * *} \\
(0.010)\end{array}$ & $\begin{array}{r}0.055^{* * *} \\
(0.010)\end{array}$ & 0.074 & $\begin{array}{r}-0.048 * * * \\
(0.012)\end{array}$ & $\begin{array}{r}0.043^{* * *} \\
(0.012)\end{array}$ \\
\hline Iraq & 0.206 & $\begin{array}{r}-0.066 * * * \\
(0.008)\end{array}$ & $\begin{array}{r}0.064 * * * \\
(0.007)\end{array}$ & 0.079 & $\begin{array}{r}-0.133^{* * *} \\
(0.012)\end{array}$ & $\begin{array}{r}0.066 * * * \\
(0.012)\end{array}$ \\
\hline Kosovo & 0.081 & $\begin{array}{r}0.047^{* * *} \\
(0.009)\end{array}$ & $\begin{array}{r}-0.051 * * * \\
(0.008)\end{array}$ & 0.095 & $\begin{array}{r}0.009 \\
(0.011)\end{array}$ & $\begin{array}{r}-0.080 * * * \\
(0.010)\end{array}$ \\
\hline Somalia & 0.122 & $\begin{array}{r}-0.111 * * * \\
(0.008)\end{array}$ & $\begin{array}{r}0.082 * * * \\
(0.008)\end{array}$ & 0.142 & $\begin{array}{r}-0.217^{* * *} \\
(0.010)\end{array}$ & $\begin{array}{r}0.232 * * * \\
(0.010)\end{array}$ \\
\hline
\end{tabular}

Note: $\quad * / * * / * * *$ Statistically significant at the $10 / 5 / 1$ percent level.

Standard errors, clustered within individual, are reported in parentheses. Regression coefficient gives the differential from the weighted average country of birth effect in the refugee sample. See also note to Table 2. 
Social insurance reflects non-employment and origin country differentials tend to have the opposite sign, but similar magnitude as the employment coefficients; see Table 6 . Among women, there are some exceptions with less social insurance claims than expected from the observed employment differential (e.g., Kosovo), while others (e.g., Eritrea) have higher social insurance rates than suggested by employment alone.

Origin country effects for family immigrants with an immigrant reference person are reported in Table 7. The origin country differentials are even more dispersed than for refugees. Among men, the largest groups are family immigrants from Pakistan and Turkey, the main source countries of the immigrant wave of the 1970s. Family migrants from Somalia and Iraq have low employment and high social insurance rates, among men as well as women. Family immigrants from Sri Lanka, on the other hand, are more likely to be employed and relatively few claim social insurance. Table 7 also reveals a distinct gender differential among Pakistanis. While men have high employment rates, few women work. For female family immigrants from Pakistan, even social insurance uptake is significantly below average suggesting widespread traditional female household responsibilities. 
Table 7: Country of birth fixed effects, main source countries in samples of family immigrants with immigrant reference person

\begin{tabular}{|c|c|c|c|c|c|c|}
\hline & \multicolumn{3}{|c|}{ Men } & \multicolumn{3}{|c|}{ Women } \\
\hline & $\begin{array}{r}\text { Percent of } \\
\text { sample }\end{array}$ & $\begin{array}{l}\text { Employ- } \\
\text { ment }\end{array}$ & $\begin{array}{r}\text { Social } \\
\text { insurance }\end{array}$ & $\begin{array}{r}\text { Percent of } \\
\text { sample }\end{array}$ & $\begin{array}{r}\text { Employ- } \\
\text { ment }\end{array}$ & $\begin{array}{r}\text { Social } \\
\text { insurance }\end{array}$ \\
\hline & (1) & (2) & (3) & (4) & (5) & (6) \\
\hline Iran & & & & 0.043 & $\begin{array}{l}-0.009 \\
(0.012)\end{array}$ & $\begin{array}{r}0.027^{* * *} \\
(0.010)\end{array}$ \\
\hline Iraq & 0.039 & $\begin{array}{r}-0.152 * * * \\
(0.018)\end{array}$ & $\begin{array}{r}0.142 * * * \\
(0.017)\end{array}$ & 0.101 & $\begin{array}{r}-0.149 * * * \\
(0.010)\end{array}$ & $\begin{array}{r}0.094^{* * *} \\
(0.008)\end{array}$ \\
\hline Morocco & 0.044 & $\begin{array}{r}0.004 \\
(0.017)\end{array}$ & $\begin{array}{r}0.016 \\
(0.016)\end{array}$ & & & \\
\hline Pakistan & 0.151 & $\begin{array}{r}0.080 * * * \\
(0.011)\end{array}$ & $\begin{array}{r}-0.063^{* * *} \\
(0.010)\end{array}$ & 0.100 & $\begin{array}{r}-0.180 * * * \\
(0.010)\end{array}$ & $\begin{array}{r}-0.070 * * * \\
(0.008)\end{array}$ \\
\hline Somalia & 0.065 & $\begin{array}{r}-0.291 * * * \\
(0.016)\end{array}$ & $\begin{array}{r}0.208 * * * \\
(0.015)\end{array}$ & 0.054 & $\begin{array}{r}-0.304 * * * \\
(0.010)\end{array}$ & $\begin{array}{r}0.252^{* * *} \\
(0.011)\end{array}$ \\
\hline Sri Lanka & 0.042 & $\begin{array}{r}0.105^{* * *} \\
(0.014)\end{array}$ & $\begin{array}{r}-0.078 * * * \\
(0.012)\end{array}$ & 0.090 & $\begin{array}{r}0.120 * * * \\
(0.010)\end{array}$ & $\begin{array}{r}-0.035^{* * *} \\
(0.008)\end{array}$ \\
\hline Turkey & 0.118 & $\begin{array}{r}-0.013 \\
(0.012)\end{array}$ & $\begin{array}{l}0.020^{*} \\
(0.011)\end{array}$ & 0.067 & $\begin{array}{r}-0.058 * * * \\
(0.011)\end{array}$ & $\begin{array}{r}0.027^{* * *} \\
(0.010)\end{array}$ \\
\hline Vietnam & 0.045 & $\begin{array}{r}0.016 \\
(0.017)\end{array}$ & $\begin{array}{l}-0.002 \\
(0.016)\end{array}$ & 0.070 & $\begin{array}{r}0.124 * * * \\
(0.011)\end{array}$ & $\begin{array}{r}-0.032 * * * \\
(0.009)\end{array}$ \\
\hline
\end{tabular}

Note: $\quad * / * * * * *$ Statistically significant at the 10/5/1 percent level.

Standard errors, clustered within individual, are reported in parentheses. Regression coefficient gives the differential from the weighted average country of birth effect in the sample of immigrants with an immigrant reference person. See also note to Table 2.

Employment and social insurance differentials among family migrants with a Norwegian born reference person are shown in Table 8. Note that this admission class will include immigrants reuniting with both ethnic Norwegian reference persons and Norwegian-born children of immigrant parents, and that this will vary across family immigrant source countries. In this admission group, men from Pakistan and Kosovo have the highest employment rates, while North African men are less likely to be employment and more frequently receive social insurance. The origin country mix of female family migrants with a Norwegian-born reference person is quite different from that of men, dominated by immigrants from Thailand and the Philippines who have above average employment rates when compared to other female family immigrants. Yet, even after adding the estimated five-percentage points advantage, the employment rate after 10-15 years is significantly below that of native women (see 
Figure 6). Again, Pakistani women have very low employment rates, although, unlike for other groups, low employment is not mirrored by high rates social insurance dependency. In general, the heterogeneity with respect to origin country is relatively modest among family immigrants with a Norwegian-born reference person.

Table 8: Country of birth fixed effects, main source countries in samples of family immigrants with Norwegian reference person

\begin{tabular}{|c|c|c|c|c|c|c|}
\hline & \multicolumn{3}{|c|}{ Men } & \multicolumn{3}{|c|}{ Women } \\
\hline & $\begin{array}{r}\text { Percent of } \\
\text { sample } \\
\text { (1) }\end{array}$ & $\begin{array}{r}\text { Employ- } \\
\text { ment } \\
\text { (2) }\end{array}$ & $\begin{array}{r}\text { Social } \\
\text { insurance } \\
\text { (3) }\end{array}$ & $\begin{array}{r}\text { Percent of } \\
\text { sample } \\
(4)\end{array}$ & $\begin{array}{r}\text { Employ- } \\
\text { ment } \\
(5)\end{array}$ & $\begin{array}{r}\text { Social } \\
\text { insurance } \\
\text { (6) }\end{array}$ \\
\hline Algeria & 0.032 & $\begin{array}{r}-0.101 * * * \\
(0.027)\end{array}$ & $\begin{array}{r}0.121 * * * \\
(0.025)\end{array}$ & & & \\
\hline Brazil & & & & 0.045 & $\begin{array}{r}-0.032^{* * *} \\
(0.012)\end{array}$ & $\begin{array}{r}0.021 * * * \\
(0.009)\end{array}$ \\
\hline China & & & & 0.020 & $\begin{array}{r}-0.038 * * * \\
(0.016)\end{array}$ & $\begin{array}{r}-0.006 \\
(0.010)\end{array}$ \\
\hline Gambia & 0.027 & $\begin{array}{r}-0.073^{* * *} \\
(0.028)\end{array}$ & $\begin{array}{r}0.052^{* *} \\
(0.026)\end{array}$ & & & \\
\hline Kosovo & 0.033 & $\begin{array}{r}0.060 * * * \\
(0.018)\end{array}$ & $\begin{array}{r}-0.029^{*} \\
(0.017)\end{array}$ & & & \\
\hline Morocco & 0.123 & $\begin{array}{r}-0.053^{* * *} \\
(0.015)\end{array}$ & $\begin{array}{r}0.057^{* * *} \\
(0.014)\end{array}$ & & & \\
\hline Pakistan & 0.115 & $\begin{array}{r}0.069 * * * \\
(0.013)\end{array}$ & $\begin{array}{r}-0.054^{* * *} \\
(0.012)\end{array}$ & 0.024 & $\begin{array}{r}-0.307^{* * *} \\
(0.017)\end{array}$ & $\begin{array}{r}0.008 \\
(0.011)\end{array}$ \\
\hline Philippines & & & & 0.169 & $\begin{array}{r}0.025^{* * *} \\
(0.009)\end{array}$ & $\begin{array}{r}-0.024 * * * \\
(0.007)\end{array}$ \\
\hline Russia & & & & 0.130 & $\begin{array}{c}0.017^{*} \\
(0.010)\end{array}$ & $\begin{array}{r}0.005 \\
(0.007)\end{array}$ \\
\hline Thailand & & & & 0.329 & $\begin{array}{r}0.046 * * * \\
(0.009)\end{array}$ & $\begin{array}{r}-0.013^{* *} \\
(0.006)\end{array}$ \\
\hline Tunisia & 0.033 & $\begin{array}{r}-0.117^{* * *} \\
(0.024)\end{array}$ & $\begin{array}{r}0.121 * * * \\
(0.022)\end{array}$ & & & \\
\hline Turkey & 0.200 & $\begin{array}{r}0.004 \\
(0.011)\end{array}$ & $\begin{array}{r}-0.003 \\
(0.010)\end{array}$ & & & \\
\hline Ukraine & & & & 0.027 & $\begin{array}{l}-0.009 \\
(0.014)\end{array}$ & $\begin{array}{l}0.017^{*} \\
(0.010)\end{array}$ \\
\hline
\end{tabular}

Note: $\quad * / * * / * * *$ Statistically significant at the $10 / 5 / 1$ percent level.

Standard errors, clustered within individual, are reported in parentheses. Regression coefficient gives the differential from the weighted average country of birth effect in the sample of immigrants with a Norwegian reference person. See also note to Table 2. 


\subsubsection{On the roles of education and selective outmigration}

Perhaps the most striking finding of the empirical analysis is that the employment gap between natives and refugees/family immigrants widens after some years of residence, mirrored by a comparable rise in immigrant reliance on social insurance. The analysis also shows that acquisition of education in Norway is associated with substantial employment gains. The years of residence (YSM) profiles in Figures 6 and 7 are drawn, however, holding educational attainment constant. For an immigrant who acquires schooling after admission, there will be a predicted boost in employment from that year onwards, not captured in the profile. For example, among refugees and family immigrants with ten years of residence, around one in three have acquired their highest educational attainment in Norway. Over the next eight years, an additional ten percentage points upgrade their education. (Detailed statistics are available upon request.) If host-country schooling is an outcome of the integration process, such postadmission educational attainment may be a "bad control" in the analysis. In particular, a concern is that the finding of widening employment gaps might be the result of such model specification issues. 
Table 9: Estimates of change in immigrant-native employment and social insurance differentials between 9 and 18 years since admission, using pre-admission educational attainment and low-education native reference groups

\begin{tabular}{|c|c|c|c|c|c|c|}
\hline & \multicolumn{3}{|c|}{ Men } & \multicolumn{3}{|c|}{ Women } \\
\hline & Refugee & $\begin{array}{r}\text { Family to } \\
\text { immigrant }\end{array}$ & $\begin{array}{r}\text { Family to } \\
\text { Norwegian }\end{array}$ & Refugee & $\begin{array}{r}\text { Family to } \\
\text { immigrant }\end{array}$ & $\begin{array}{r}\text { Family to } \\
\text { Norwegian }\end{array}$ \\
\hline & (1) & (2) & (3) & (4) & (5) & (6) \\
\hline \multicolumn{7}{|l|}{ A. Employment } \\
\hline 1. Baseline (Fig 6) & $\begin{array}{r}-0.092 * * * \\
(0.004)\end{array}$ & $\begin{array}{r}-0.091 * * * \\
(0.008)\end{array}$ & $\begin{array}{r}-0.128 * * * \\
(0.011)\end{array}$ & $\begin{array}{r}-0.055^{* * *} \\
(0.006)\end{array}$ & $\begin{array}{r}-0.035^{* * *} \\
(0.006)\end{array}$ & $\begin{array}{r}-0.080 * * * \\
(0.009)\end{array}$ \\
\hline $\begin{array}{l}\text { 2. Fix educ pre- } \\
\text { admission }\end{array}$ & $\begin{array}{r}-0.074^{* * *} \\
(0.004)\end{array}$ & $\begin{array}{r}-0.086 * * * \\
(0.009)\end{array}$ & $\begin{array}{r}-0.123^{* * *} \\
(0.011)\end{array}$ & $\begin{array}{r}-0.033^{* * *} \\
(0.006)\end{array}$ & $\begin{array}{r}-0.005 \\
(0.006)\end{array}$ & $\begin{array}{r}-0.056 * * * \\
(0.009)\end{array}$ \\
\hline $\begin{array}{l}\text { 3. Drop educ from } \\
\text { model }\end{array}$ & $\begin{array}{r}-0.070 * * * \\
(0.005)\end{array}$ & $\begin{array}{r}-0.079 * * * \\
(0.010)\end{array}$ & $\begin{array}{r}-0.115^{* * *} \\
(0.011)\end{array}$ & $\begin{array}{r}-0.024 * * * \\
(0.006)\end{array}$ & $\begin{array}{r}0.008 \\
(0.006)\end{array}$ & $\begin{array}{r}-0.039 * * * \\
(0.009)\end{array}$ \\
\hline 4. Low educ ref & $\begin{array}{r}-0.063^{* * *} \\
(0.006)\end{array}$ & $\begin{array}{r}-0.089 * * * \\
(0.012)\end{array}$ & $\begin{array}{r}-0.126 * * * \\
(0.013)\end{array}$ & $\begin{array}{r}-0.036 * * * \\
(0.007)\end{array}$ & $\begin{array}{r}-0.027^{* * *} \\
(0.007)\end{array}$ & $\begin{array}{r}-0.070 * * * \\
(0.010)\end{array}$ \\
\hline \multicolumn{7}{|l|}{ B. Social insurance } \\
\hline 1. Baseline (Fig 7) & $\begin{array}{r}0.071 * * * \\
(0.004)\end{array}$ & $\begin{array}{r}0.080 * * * \\
(0.009)\end{array}$ & $\begin{array}{r}0.096 * * * \\
(0.010)\end{array}$ & $\begin{array}{r}0.077^{* * *} \\
(0.006)\end{array}$ & $\begin{array}{r}0.062 * * * \\
(0.006)\end{array}$ & $\begin{array}{r}0.070 * * * \\
(0.008)\end{array}$ \\
\hline $\begin{array}{l}\text { 2. Fix educ pre- } \\
\text { admission }\end{array}$ & $\begin{array}{r}0.056 * * * \\
(0.004)\end{array}$ & $\begin{array}{r}0.082 * * * \\
(0.009)\end{array}$ & $\begin{array}{r}0.097^{* * *} \\
(0.010)\end{array}$ & $\begin{array}{r}0.062 * * * \\
(0.006)\end{array}$ & $\begin{array}{r}0.059 * * * \\
(0.006)\end{array}$ & $\begin{array}{r}0.067^{* * *} \\
(0.008)\end{array}$ \\
\hline $\begin{array}{l}\text { 3. Drop educ from } \\
\text { model }\end{array}$ & $\begin{array}{r}0.050 * * * \\
(0.004)\end{array}$ & $\begin{array}{r}0.077^{* * *} \\
(0.009)\end{array}$ & $\begin{array}{r}0.089 * * * \\
(0.011)\end{array}$ & $\begin{array}{r}0.053^{* * *} \\
(0.006)\end{array}$ & $\begin{array}{r}0.045^{* * *} \\
(0.006)\end{array}$ & $\begin{array}{r}0.049 * * * \\
(0.008)\end{array}$ \\
\hline 4. Low educ ref & $\begin{array}{r}0.043^{* * *} \\
(0.005)\end{array}$ & $\begin{array}{r}0.088 * * * \\
(0.011)\end{array}$ & $\begin{array}{r}0.100 * * * \\
(0.013)\end{array}$ & $\begin{array}{r}0.060 * * * \\
(0.007)\end{array}$ & $\begin{array}{r}0.074 * * * \\
(0.007)\end{array}$ & $\begin{array}{r}0.076 * * * \\
(0.010)\end{array}$ \\
\hline
\end{tabular}

Note: $\quad * / * * * * *$ Statistically significant at the $10 / 5 / 1$ percent level.

Standard errors are reported in parentheses. Regression coefficients give the change in immigrantnative differential between 9 and 18 years since entry. Specification 1 is identical to that underlying Figures 6 and 7; specification 2 restricts attainment at pre-admission levels for immigrants and age 30 for natives; specifications 3 and 4 drop all educational attainment terms from the regression model; and specification 4 further restricts the native reference group to those without completed upper secondary education at age 30 .

To address this concern, in Table 9 we report results from a number of sensitivity checks, focusing on refugees and family immigrants and the span of residence years where we observe widening employment gaps for both males and females (i.e., 
between 9 and 18 years after admission). First, row $A_{1}$ lists the predicted change in the immigrant-native employment differential over the time interval based on the model underlying Figure 6, showing, for example, that the employment gap between male refugees and natives increases by 9.2 percentage points between 9 and 18 years since entry. Next, row $A_{2}$ shows the predicted change from an alternative model specification that ignores any post-admission educational attainment. Compared to the predictions in Figure 6, the widening of the employment gap is slightly lower, and more so for women, but the overall patterns are very similar. Even when we drop any information on educational attainment from the empirical model, results show a widening employment gap, at least for men (see row $A_{3}$ ). Recall that this exercise focuses on the change in the gap over a nine-year period, and not the predicted size of the gap, which grows larger when the specification ignores differences in educational attainment between immigrants and natives. Finally, in row $\mathrm{A}_{4}$, we report the estimated change in the employment gap when the native reference group consists of those without completed upper secondary education. Again, while the estimated change in the employment gap is attenuated (by approximately one third) for refugees, the predictions are very similar to those in Figure 6 for other groups. Finally, in Panel B we repeat the same checks for the social insurance outcome. As the panel shows, the qualitative finding of more rapid increase in social insurance uptake among refugees and family immigrants, relative to natives, is not sensitive to specification or model inclusion of educational attainment, nor to the use of loweducation native control groups.

A general concern in studies of immigrant assimilation is that employment profiles over years since entry, like those in Figures 6 and 7, may be impacted by selective outmigration. In our context, one might worry that the widening employment gap is an artifact of positively selected outmigration, whereby immigrants with better employment prospects are more likely to leave the country over time. Again, focusing on refugees and family immigrants, Table 10 reports various checks that all reject the notion that the estimated decline in employment is caused by selective outmigration.

First, panel A shows that a fairly small fraction (about $6 \%$ for most groups) leaves the country between 9 and 18 years after entry, limiting the scope for bias from selective outmigration. Second, when we examine the employment careers of outmigrants and stayers during their first nine years in the country, we find that the probability of staying for another nine years correlates positively with early employment success (see panel A, row labelled "Coeff of average employment years 1- 
$9 ")$. The implication is that any selection is the exact opposite of what could have generated a declining employment rate in the unbalanced sample. Third, when we reestimate the full model based on the sample of individuals present after both 9 and 18 years (see panel B, "balanced panel"), the relative employment drop and social insurance uptake over the nine-year period are comparable to those presented Table 9 (rows labelled "baseline"). There is indeed a tendency for the estimated employment drop to become a bit smaller in the balanced panel, but given the results in panel $A$, this is more likely to result from the considerable changes in cohort composition implied by the requirement of at least 18 years stay in Norway than from selective outmigration. The central conclusion to be drawn from Table 10 is in any case that the significant increase in the immigrant-native employment differential after nine years of residence is a highly robust result.

Table 10: Accounting for outmigration, samples of refugees and family immigrants

\begin{tabular}{|c|c|c|c|c|c|c|}
\hline & \multicolumn{3}{|c|}{ Men } & \multicolumn{3}{|c|}{ Women } \\
\hline & Refugee & $\begin{array}{l}\text { Family to } \\
\text { immigrant }\end{array}$ & $\begin{array}{l}\text { Family to } \\
\text { Norwegian }\end{array}$ & Refugee & $\begin{array}{l}\text { Family to } \\
\text { immigrant }\end{array}$ & $\begin{array}{l}\text { Family to } \\
\text { Norwegian }\end{array}$ \\
\hline & (1) & (2) & (3) & (4) & (5) & (6) \\
\hline \multicolumn{7}{|c|}{ A. Prob(remain in Norway between 9 and 18 yrs since entry) } \\
\hline Stay rate & 0.932 & 0.936 & 0.902 & 0.948 & 0.934 & 0.952 \\
\hline $\begin{array}{l}\text { Coeff of avg } \\
\text { emplyrs 1-9 } \\
\text { Observations }\end{array}$ & $\begin{array}{r}0.084 * * * \\
(0.009) \\
8,004\end{array}$ & $\begin{array}{r}0.158 * * * \\
(0.020) \\
1,868\end{array}$ & $\begin{array}{r}0.169 * * * \\
(0.029) \\
1,401\end{array}$ & $\begin{array}{r}0.059 * * * \\
(0.009) \\
5,917\end{array}$ & $\begin{array}{r}0.073^{* * *} \\
(0.009) \\
6,251\end{array}$ & $\begin{array}{r}0.071 * * * \\
(0.012) \\
2,838\end{array}$ \\
\hline \multicolumn{7}{|c|}{ B. Change in immigrant native difference between 9 and $18 \mathrm{yrs}$ since entry } \\
\hline Employment & $\begin{array}{r}-0.088 * * * \\
(0.005)\end{array}$ & $\begin{array}{r}-0.074 * * * \\
(0.012)\end{array}$ & $\begin{array}{r}-0.094 * * * \\
(0.014)\end{array}$ & $\begin{array}{r}-0.067^{* * *} \\
(0.007)\end{array}$ & $\begin{array}{r}-0.016 * * \\
(0.008)\end{array}$ & $\begin{array}{r}-0.037^{* * *} \\
(0.011)\end{array}$ \\
\hline Social insurance & $\begin{array}{r}0.058 * * * \\
(0.005)\end{array}$ & $\begin{array}{r}0.056 * * * \\
(0.012)\end{array}$ & $\begin{array}{r}0.061 * * * \\
(0.013)\end{array}$ & $\begin{array}{r}0.067 * * * \\
(0.007)\end{array}$ & $\begin{array}{r}0.058 * * \\
(0.007)\end{array}$ & $\begin{array}{r}0.041 * * * \\
(0.011)\end{array}$ \\
\hline Observations & 135,900 & 26,678 & 22,022 & 101,371 & 93,742 & 42,138 \\
\hline
\end{tabular}

Note: $\quad * / * * / * * *$ Statistically significant at the $10 / 5 / 1$ percent level.

Standard errors are reported in parentheses. Samples in Panel A are restricted to those who entered before 1998 and who remained in Norway at least 9 years. The coefficient of the average individual employment rate stems from a regression of an indicator variable for whether or not the immigrant remained in Norway 18 years after entry on the average employment rate yrs 1-9 and the individual regressors listed in note to Table 2. Regression coefficients in Panel B give the differential between 18 and 9 years since entry in the balanced panel of immigrants included the regression sample at least 18 years since entry. 


\subsection{Discussion and concluding remarks}

The main message coming out of our longitudinal analyses is that the labor market integration of immigrants from low-income countries tends to lose steam after just a few years in Norway, and that the integration process then goes into reverse. After five to ten years of residence, virtually all immigrant groups from low-income countries regardless of gender and admission class - experience declining employment rates and increasing social insurance dependency rates relative to natives with shared characteristics. At first sight, this stands in sharp contrast to recent European crosssectional evidence suggesting that the immigrant-native employment differentials are reduced with years since migration (Dustmann et al., 2016; Dumont et al., 2016). However, given the large heterogeneity in integration patterns and employment levels across different immigrant groups, particularly related to origin country, gender, and admission class, these apparently contradictory results are not necessarily incompatible. In cross-sectional data, the empirical association between labor market success and years since migration will not only capture the impacts of time spent in the host country, but also any differences in the composition of arrival cohorts. For example, if - for some reason - cohorts that arrived 10-20 years ago are more successful than more recent cohorts, this will show up in a cross-sectional analysis as a sign of improved labor market integration over time. Hence, we will argue that it is difficult to assign a particular causal interpretation to findings based on cross-sectional data, and that in order to identify the causal impacts of years since migration, it is necessary with longitudinal data that follow the same immigrants over time. This general point does of course not rule out that there are important differences in the labor market integration processes between Norway and other European countries, and that the disintegration tendencies we have identified after a few years of residence are specific to Norway.

To the extent that immigrants from low-income countries really are subjected to a labor market disintegration process after just a few years in the host country, the big question is why this happens? While our study cannot provide fully satisfactory answers to this question, our findings do point us in some specific directions. First, it is clear that business cycles play a very important role, as the impact of local labor market conditions on individual employment propensity is an order of magnitude larger for immigrants than for natives. This is not only a reflection of the fact that newcomers in the labor market in general are more sensitive with respect to labor demand 
fluctuations. Recent empirical evidence shows that already employed immigrants from low-income countries are heavily overrepresented in precarious firms (firms with a high probability of downsizing or closing down in the near future), and that the subsequent consequences of job loss in terms of future non-employment are also much more severe for immigrants than for their native co-workers (Bratsberg et al., 2016a).

Second, we have found that human capital is a very strong predictor for labor market success, and that additional education acquired in Norway can be of great value, particularly for refugees and female family immigrants, even when it is below their highest educational attainment from abroad.

Third, we have shown that declining employment rates are almost fully mirrored by increasing reliance on social insurance transfers, particularly for male immigrants. Since the major social program behind this pattern is that of disability insurance, this suggests that poor and deteriorating health is an important driver behind labor market exit. Alternatively, it may reflect that immigrants are overrepresented in jobs that are physically and/or mentally demanding, such that a given health problem become a greater barrier for immigrants than for natives. Existing empirical evidence from Norway has shown that there is a considerable grey area between unemployment and disability, and that disability insurance claims frequently are triggered by job loss (Rege et al., 2009; Bratsberg et al., 2013). The high and rapidly increasing rates of social insurance dependency among immigrants from low-income countries can also to some extent be explained by the fact that these groups on average have higher social insurance replacement ratios, and respond more strongly to these incentives than other immigrants and natives (Bratsberg et al., 2016b). The higher replacement ratios among LDC immigrants result from a combination of a progressive social insurance system (with a relatively high floor and additional allowances for children) and poor labor market opportunities (with low wages and presumably also relatively poor working conditions). The larger behavioral responses result from a higher fraction of immigrants being in a situation where there is a small overall utility difference between the states of employment and non-employment; see Bratsberg et al. (2016b) for a discussion.

There is of course no reason to believe that the employment and earnings potentials among immigrants are exactly the same as those of natives. After all, most of the immigrants from low-income countries are admitted on humanitarian grounds, many have poor language skills and low (marketable) education, and a considerable fraction has been through traumatic events and arrive in the host country with serious health impediments. There also exists empirical evidence indicating that there is a 
tendency for Norwegian employers to discriminate against job applicants with foreignsounding names (Birkelund et al., 2014). However, while these factors can explain why employment rates may never reach parity with natives, they cannot readily explain why employment rates decline after just a few years in the country. This latter finding indicates that potentially productive resources are underused, and thus that there is scope for policy to improve on the outcomes.

Given the much higher employment levels found among immigrants with secondary or tertiary education acquired in Norway, more intensive human capital investment is an obvious policy candidate. Although rapid introduction to the labor market probably is of great value for many immigrants, our study also illuminates that finding a first job is not sufficient to ensure labor market participation over the long haul. These first jobs are apparently often short-lived, and in order to obtain a more solid foothold in the labor market, more adaptable human capital may be necessary, including a minimum level of education and command of the majority language. In fact, steps have already been taken in this direction, e.g., through the establishment in 2004 of the introduction program targeted at newly arrived humanitarian immigrants. The program is designed as a two-year education/work program, which from 2016 also facilitates full-time secondary education.

As our study also indicates a major role for social insurance programs, a second policy candidate is to reform these programs in order to improve work incentives. One possibility is to make them less attractive by reducing the benefit levels. However, an undesirable side effect of this strategy could be to increase inequality and raise poverty in immigrant families, potentially with adverse consequences for the second generation. Alternatively, the social insurance programs could be designed in a more job-oriented fashion, e.g., by encouraging combinations of graded disability insurance and adapted full-time work; i.e., spending public money on subsidizing employment rather than non-employment. 


\section{References}

Barth, E., Bratsberg, B., and Raaum, O. (2004), Identifying Earnings Assimilation of Immigrants under Changing Macroeconomic Conditions, Scandinavian Journal of Economics, 106 (1), 1-22. https://doi.org/10.1111/j.0347-0520.2004.to1-1-00345.X

Birkelund, G. E., Rogstad, J., Heggebø, K., Aspøy, T. M. og Bjelland, H. F. (2014), Diskriminering i arbeidslivet - Resultater fra randomiserte felteksperiment i Oslo, Stavanger, Bergen og Trondheim. Sosiologisk Tidsskrift, 22(4), 352-382.

Borjas, G.J. (1982), The Earnings of Male Hispanic Immigrants in the United States, ILR Review 35(3), 343-353. https://doi.org/10.1177/001979398203500304

Borjas, G.J. (1995), Assimilation and changes in cohort quality revisited: what happened to immigrant earnings in the 1980s? Journal of Labor Economics, Vol. 13, No. 2, 201-245. https://doi.org/10.1086/298373

Borjas, G.J. (1999), The Economic Analysis of Immigration. In Handbook of Labour Economics, Vol. 3, edited by Orley C. Ashenfelter and David Card, pp. 1697-176o. Amsterdam: Elsevier. https://doi.org/10.1016/s1573-4463(99)03009-6

Bratsberg, B., Barth, E., and Raaum, O. (2006), Local Unemployment and the Relative Wages of Immigrants: Evidence from the Current Population Surveys. Review of Economics and Statistics, Vol. 88, No. 2, 243-263. https://doi.org/10.1162/rest.88.2.243

Bratsberg, B., Fevang, E., and Røed, K. (2013), Job Loss and Disability Insurance. Labour Economics 24, 137-150. https://doi.org/10.1016/j.labeco.2013.08.004

Bratsberg, B., Raaum, O., and Røed, K. (2010), When Minority Labor Migrants Meet the Welfare State, Journal of Labor Economics, 28(3), 633-676. https://doi.org/10.1086/650546

Bratsberg, B., Raaum, O., and Røed, K. (2014), Immigrants, Labour Market Performance, and Social Insurance, Economic Journal, 124(580), F644-F683. https://doi.org/10.1111/ecoj.12182

Bratsberg, B., Raaum, O., and Røed, K. (2016a), Job Loss and Immigrant Labor Market Performance. IZA Discussion Paper No. 9729 and CReAM Discussion Paper No 02/16

Bratsberg, B., Raaum, O., and Røed, K. (2016b), Immigrant Responses to Social Insurance Generosity. In progress.

Bratsberg, B., Raaum, O., and Røed, K. (2016c), Labor market integration of refugees in Norway, in F. Fasani (ed), Refugees and Economic Migrants: Facts, policies and challenges, VoxEU.org Book, CEPR Press: 37-52.

Clemens, M.A. (2011), "Economics and Emigration: Trillion-Dollar Bills on the Sidewalk?" Journal of Economic Perspectives, Volume 25, Number 3, Summer 2011, pp. 83-106(24).

Cortes, K.E. (2004), Are Refugees Different from Economic Immigrants? Some Empirical Evidence on the Heterogeneity of Immigrant Groups in the United States, Review of Economics and Statistics 86(2), 465-480. https://doi.org/10.1162/003465304323031058

Damas de Matos, A., and Liebig, T. (2014), The qualifications of immigrants and their value in the labour market: A comparison of Europe and the United States, in OECD/EU, Matching Economic Migration with Labour Market Needs, OECD Publishing, Paris. https://doi.org/10.1787/9789264216501-9-en 
Dustmann, C., Glitz, A., and Vogel, T. (2010), Employment, Wages, and the Economic Cycle: Differences between Immigrants and Natives. European Economic Review, 54(1), 1-17. https://doi.org/10.1016/j.euroecorev.2009.04.004

Dustmann, C., Fasani, F., Frattini, T., Minale, L., and Schönberg, U. (2016), On the Economics and Politics of Refugee Migration, CreAM, Discussion paper 16/2016, University College London.

Dumont, J-C, Liebig, T., Peschner, J., Tanay, F., and Xenogiani, T. (2016), How are refugees faring on the labour market in Europe? A first evaluation based on the 2014 EU LFS. Working Paper 1/2106, EC and OECD.

Husted, L., Nielsen, H. S., Rosholm, M., and Smith, N. (2001), Employment and Wage Assimilation of Male First-Generation Immigrants in Denmark, International Journal of Manpower 22(1/2), 39-68. https://doi.org/10.1108/01437720110386377

Kennan, J. (2013) Open borders, Review of Economic Dynamics, Vol. 16(2), L1-13. https://doi.org/10.1016/j.red.2012.08.003

Luik, M-A., Emilsson, H., and Bevelander. P. (2016), Explaining the Male Native-Immigrant Employment Gap in Sweden: The role of Human Capital and Migrant Categories, IZA DP No. 9943.

Lundborg, P. (2013), Refugees' Employment Integration in Sweden: Cultural Distance and Labor Market Performance, Review of International Economics 21(2), 219-232. https://doi.org/10.1111/roie.12032

Rege, M., Telle, K., and Votruba, M. (2009), The Effect of Plant Downsizing on Disability Pension Utilization. Journal of the European Economic Association 7(5), 754-785. https://doi.org/10.1162/JEEA.2009.7.4.754

Sarvimäki, M. (2011), Assimilation to a Welfare State: Labor Market Performance and Use of Social Benefits by Immigrants to Finland, Scandinavian Journal of Economics 113(3), 665-688. https://doi.org/10.1111/j.1467-9442.2011.01652.x

Sarvimäki, M. (2017), Labor market integration of refugees in Finland, this volume.

Schultz-Nielsen, M. L. (2017), Labour Market Integration of Refugees in Denmark, this volume.

Storesletten, K. (2000), Sustaining fiscal policy through immigration, Journal of Political Economy 108, 300-23. https://doi.org/10.1086/262120

Åslund, O., Forslund, A., and Liljeberg, L. (2017), Labour market entry of refugees-Swedish evidence, this volume. 


\section{Appendix}

Table A1: Estimated difference in immigrant-native employment differential relative to that at 9 years since entry under alternative education specifications; refugee samples

\begin{tabular}{|c|c|c|c|c|c|c|c|c|}
\hline \multirow{2}{*}{$\begin{array}{l}\text { Years } \\
\text { since } \\
\text { entry }\end{array}$} & \multicolumn{4}{|c|}{ Men } & \multicolumn{4}{|c|}{ Women } \\
\hline & (1) & (2) & (3) & (4) & (5) & (6) & (7) & (8) \\
\hline 1 & $\begin{array}{r}-0.330 * * * \\
(0.003)\end{array}$ & $\begin{array}{r}-0.365^{* * *} \\
(0.003)\end{array}$ & $\begin{array}{r}-0.362 * * * \\
(0.003)\end{array}$ & $\begin{array}{r}-0.368 * * * \\
(0.004)\end{array}$ & $\begin{array}{r}-0.320 * * * \\
(0.004)\end{array}$ & $\begin{array}{r}-0.393^{* * *} \\
(0.004)\end{array}$ & $\begin{array}{r}-0.396 * * * \\
(0.004)\end{array}$ & $\begin{array}{r}-0.372 * * * \\
(0.005)\end{array}$ \\
\hline 2 & $\begin{array}{r}-0.220 * * * \\
(0.003)\end{array}$ & $\begin{array}{r}-0.252^{* * *} \\
(0.003)\end{array}$ & $\begin{array}{r}-0.250^{* * *} \\
(0.003)\end{array}$ & $\begin{array}{r}-0.256 * * * \\
(0.004)\end{array}$ & $\begin{array}{r}-0.261 * * * \\
(0.004)\end{array}$ & $\begin{array}{r}-0.330 * * * \\
(0.004)\end{array}$ & $\begin{array}{r}-0.333^{* * *} \\
(0.005)\end{array}$ & $\begin{array}{r}-0.314 * * * \\
(0.005)\end{array}$ \\
\hline 3 & $\begin{array}{r}-0.074^{* * *} \\
(0.003)\end{array}$ & $\begin{array}{r}-0.099^{* * *} \\
(0.003)\end{array}$ & $\begin{array}{r}-0.098 * * * \\
(0.003)\end{array}$ & $\begin{array}{r}-0.104^{* * *} \\
(0.004)\end{array}$ & $\begin{array}{r}-0.162 * * * \\
(0.005)\end{array}$ & $\begin{array}{r}-0.223^{* * *} \\
(0.005)\end{array}$ & $\begin{array}{r}-0.226 * * * \\
(0.005)\end{array}$ & $\begin{array}{r}-0.210 * * * \\
(0.005)\end{array}$ \\
\hline 4 & $\begin{array}{r}0.000 \\
(0.003)\end{array}$ & $\begin{array}{r}-0.020 * * * \\
(0.003)\end{array}$ & $\begin{array}{r}-0.018 * * * \\
(0.003)\end{array}$ & $\begin{array}{r}-0.023 * * * \\
(0.004)\end{array}$ & $\begin{array}{r}-0.079 * * * \\
(0.005)\end{array}$ & $\begin{array}{r}-0.129 * * * \\
(0.005)\end{array}$ & $\begin{array}{r}-0.131 * * * \\
(0.005)\end{array}$ & $\begin{array}{r}-0.119 * * * \\
(0.005)\end{array}$ \\
\hline 5 & $\begin{array}{r}0.024 * * * \\
(0.003)\end{array}$ & $\begin{array}{r}0.009 * * \\
(0.003)\end{array}$ & $\begin{array}{r}0.009 * * \\
(0.003)\end{array}$ & $\begin{array}{r}0.006 \\
(0.004)\end{array}$ & $\begin{array}{r}-0.037^{* * *} \\
(0.005)\end{array}$ & $\begin{array}{r}-0.075^{* * *} \\
(0.005)\end{array}$ & $\begin{array}{r}-0.076 * * * \\
(0.005)\end{array}$ & $\begin{array}{r}-0.067^{* * *} \\
(0.005)\end{array}$ \\
\hline 6 & $\begin{array}{r}0.023^{* * *} \\
(0.003)\end{array}$ & $\begin{array}{r}0.012 * * * \\
(0.003)\end{array}$ & $\begin{array}{r}0.012 * * * \\
(0.003)\end{array}$ & $\begin{array}{l}0.010 * \\
(0.004)\end{array}$ & $\begin{array}{r}-0.013^{* *} \\
(0.005)\end{array}$ & $\begin{array}{r}-0.039 * * * \\
(0.005)\end{array}$ & $\begin{array}{r}-0.040 * * * \\
(0.005)\end{array}$ & $\begin{array}{r}-0.033^{* * *} \\
(0.005)\end{array}$ \\
\hline 7 & $\begin{array}{r}0.016 * * * \\
(0.003)\end{array}$ & $\begin{array}{r}0.009 * * \\
(0.003)\end{array}$ & $\begin{array}{r}0.009 * * \\
(0.003)\end{array}$ & $\begin{array}{l}0.008 * \\
(0.004)\end{array}$ & $\begin{array}{r}-0.005 \\
(0.005)\end{array}$ & $\begin{array}{r}-0.020 * * * \\
(0.005)\end{array}$ & $\begin{array}{r}-0.021 * * * \\
(0.005)\end{array}$ & $\begin{array}{r}-0.016 * * \\
(0.005)\end{array}$ \\
\hline 8 & $\begin{array}{l}0.008^{*} \\
(0.003)\end{array}$ & $\begin{array}{r}0.005 \\
(0.003)\end{array}$ & $\begin{array}{r}0.005 \\
(0.003)\end{array}$ & $\begin{array}{r}0.005 \\
(0.004)\end{array}$ & $\begin{array}{r}-0.002 \\
(0.005)\end{array}$ & $\begin{array}{l}-0.009 \\
(0.005)\end{array}$ & $\begin{array}{r}-0.008 \\
(0.005)\end{array}$ & $\begin{array}{r}-0.006 \\
(0.006)\end{array}$ \\
\hline 9 (ref) & & & & & & & & \\
\hline 10 & $\begin{array}{r}-0.012 * * * \\
(0.003)\end{array}$ & $\begin{array}{r}-0.010 * * \\
(0.003)\end{array}$ & $\begin{array}{r}-0.010 * * \\
(0.003)\end{array}$ & $\begin{array}{r}-0.010 * \\
(0.004)\end{array}$ & $\begin{array}{r}-0.003 \\
(0.005)\end{array}$ & $\begin{array}{r}0.002 \\
(0.005)\end{array}$ & $\begin{array}{r}0.002 \\
(0.005)\end{array}$ & $\begin{array}{r}-0.001 \\
(0.006)\end{array}$ \\
\hline 11 & $\begin{array}{r}-0.023^{* * *} \\
(0.003)\end{array}$ & $\begin{array}{r}-0.018 * * * \\
(0.003)\end{array}$ & $\begin{array}{r}-0.018 * * * \\
(0.003)\end{array}$ & $\begin{array}{r}-0.016 * * * \\
(0.004)\end{array}$ & $\begin{array}{r}-0.007 \\
(0.005)\end{array}$ & $\begin{array}{r}0.002 \\
(0.005)\end{array}$ & $\begin{array}{r}0.003 \\
(0.005)\end{array}$ & $\begin{array}{r}-0.001 \\
(0.006)\end{array}$ \\
\hline 12 & $\begin{array}{r}-0.032^{* * *} \\
(0.003)\end{array}$ & $\begin{array}{r}-0.026 * * * \\
(0.003)\end{array}$ & $\begin{array}{r}-0.025^{* * *} \\
(0.003)\end{array}$ & $\begin{array}{r}-0.022 * * * \\
(0.004)\end{array}$ & $\begin{array}{r}-0.021 * * * \\
(0.005)\end{array}$ & $\begin{array}{l}-0.011 * \\
(0.005)\end{array}$ & $\begin{array}{r}-0.008 \\
(0.005)\end{array}$ & $\begin{array}{r}-0.014^{*} \\
(0.006)\end{array}$ \\
\hline 13 & $\begin{array}{r}-0.044^{* * *} \\
(0.003)\end{array}$ & $\begin{array}{r}-0.037^{* * *} \\
(0.003)\end{array}$ & $\begin{array}{r}-0.035^{* * *} \\
(0.004)\end{array}$ & $\begin{array}{r}-0.031 * * * \\
(0.004)\end{array}$ & $\begin{array}{r}-0.038 * * * \\
(0.005)\end{array}$ & $\begin{array}{r}-0.025^{* * *} \\
(0.005)\end{array}$ & $\begin{array}{r}-0.021 * * * \\
(0.005)\end{array}$ & $\begin{array}{r}-0.028 * * * \\
(0.006)\end{array}$ \\
\hline 14 & $\begin{array}{r}-0.060 * * * \\
(0.004)\end{array}$ & $\begin{array}{r}-0.051 * * * \\
(0.004)\end{array}$ & $\begin{array}{r}-0.049 * * * \\
(0.004)\end{array}$ & $\begin{array}{r}-0.044^{* * *} \\
(0.004)\end{array}$ & $\begin{array}{r}-0.045^{* * *} \\
(0.005)\end{array}$ & $\begin{array}{r}-0.030 * * * \\
(0.005)\end{array}$ & $\begin{array}{r}-0.025^{* * *} \\
(0.005)\end{array}$ & $\begin{array}{r}-0.032 * * * \\
(0.006)\end{array}$ \\
\hline 16 & $\begin{array}{r}-0.088 * * * \\
(0.004)\end{array}$ & $\begin{array}{r}-0.074^{* * *} \\
(0.004)\end{array}$ & $\begin{array}{r}-0.070 * * * \\
(0.004)\end{array}$ & $\begin{array}{r}-0.066 * * * \\
(0.005)\end{array}$ & $\begin{array}{r}-0.050 * * * \\
(0.006)\end{array}$ & $\begin{array}{r}-0.033^{* * *} \\
(0.006)\end{array}$ & $\begin{array}{r}-0.025^{* * *} \\
(0.006)\end{array}$ & $\begin{array}{r}-0.036 * * * \\
(0.007)\end{array}$ \\
\hline 17 & $\begin{array}{r}-0.095^{* * *} \\
(0.004)\end{array}$ & $\begin{array}{r}-0.078 * * * \\
(0.004)\end{array}$ & $\begin{array}{r}-0.074^{* * *} \\
(0.004)\end{array}$ & $\begin{array}{r}-0.069^{* * *} \\
(0.005)\end{array}$ & $\begin{array}{r}-0.053^{* * *} \\
(0.006)\end{array}$ & $\begin{array}{r}-0.034^{* * *} \\
(0.006)\end{array}$ & $\begin{array}{r}-0.025^{* * *} \\
(0.006)\end{array}$ & $\begin{array}{r}-0.038 * * * \\
(0.007)\end{array}$ \\
\hline 18 & $\begin{array}{r}-0.092 * * * \\
(0.004)\end{array}$ & $\begin{array}{r}-0.074^{* * *} \\
(0.004)\end{array}$ & $\begin{array}{r}-0.070^{* * *} \\
(0.005)\end{array}$ & $\begin{array}{r}-0.063^{* * *} \\
(0.006)\end{array}$ & $\begin{array}{r}-0.055^{* * *} \\
(0.006)\end{array}$ & $\begin{array}{r}-0.033^{* * *} \\
(0.006)\end{array}$ & $\begin{array}{r}-0.024 * * * \\
(0.006)\end{array}$ & $\begin{array}{r}-0.036 * * * \\
(0.007)\end{array}$ \\
\hline 19 & $\begin{array}{r}-0.093 * * * \\
(0.005)\end{array}$ & $\begin{array}{r}-0.074^{* * *} \\
(0.005)\end{array}$ & $\begin{array}{r}-0.068 * * * \\
(0.005)\end{array}$ & $\begin{array}{r}-0.060 * * * \\
(0.006)\end{array}$ & $\begin{array}{r}-0.050 * * * \\
(0.006)\end{array}$ & $\begin{array}{r}-0.026 * * * \\
(0.006)\end{array}$ & $\begin{array}{c}-0.015^{*} \\
(0.007)\end{array}$ & $\begin{array}{r}-0.027^{* * *} \\
(0.007)\end{array}$ \\
\hline 20 & $\begin{array}{r}-0.099 * * * \\
(0.005)\end{array}$ & $\begin{array}{r}-0.078 * * * \\
(0.005)\end{array}$ & $\begin{array}{r}-0.072 * * * \\
(0.005)\end{array}$ & $\begin{array}{r}-0.063^{* * *} \\
(0.006)\end{array}$ & $\begin{array}{r}-0.047^{* * *} \\
(0.007)\end{array}$ & $\begin{array}{r}-0.019 * * \\
(0.007)\end{array}$ & $\begin{array}{l}-0.005 \\
(0.007)\end{array}$ & $\begin{array}{c}-0.017^{*} \\
(0.008)\end{array}$ \\
\hline Comment & Baseline & $\begin{array}{l}\text { Fix educ } \\
\text { pre-migr }\end{array}$ & Drop educ & $\begin{array}{l}\text { Low-educ } \\
\text { reference }\end{array}$ & Baseline & $\begin{array}{l}\text { Fix educ } \\
\text { pre-migr }\end{array}$ & Drop educ & $\begin{array}{l}\text { Low-educ } \\
\text { reference }\end{array}$ \\
\hline
\end{tabular}

Note: $\quad * / * * * * *$ Statistically significant at the $10 / 5 / 1$ percent level.

All estimates are relative to the predicted immigrant-native differentials at nine years of residence. 


\title{
2. Labour market integration of refugees in Denmark7
}

Marie Lovise Schultz-Nielsen ${ }^{8}$

\begin{abstract}
The aim of the article is to analyse the labour market integration of refugees and family reunified with refugees in Denmark. The analysis is based on register data including all refugees and their family members who obtained their (first) residence permit in the period from 1997 to 2011. Refugees are tracked from their arrival and until 2014 in order to analyse the extent to which their labour market attachment improves with their length of stay in Denmark. The three main outcomes analysed are: employment rates, annual earnings and transfer payments (including social assistance, unemployment-, housing- and child benefits). The analysis shows that even though refugees' labour market attachment may improve with years of residence in Denmark, they continue to have a low labour market attachment compared not only to natives, but also to other immigrants.
\end{abstract}

- Keywords: Assimilation, immigrants, employment, earnings, welfare dependency.

- JEL-codes: J15, J31, J61.

7 I would like to thank Mie Hjortskov Andersen and Rebecca Overgaard Udsen for computational assistance and Bodil Nielsen for proof-reading. I would also like to thank the editors Anna Piil Damm and Olof Åslund as well as the reviewers Bernt Bratsberg and Torben Tranæs for their helpful comments and suggestions.

${ }^{8}$ Rockwool Foundation Research Unit, Sølvgade 10, 2nd floor, 1307 Copenhagen K, Denmark, phone: +45333448 o3, email:mls@rff.dk 


\section{$2.1 \quad$ Introduction}

In 2015 more than 1 million asylum seekers arrived in Europe and this occurrence which has been labelled "The Refugee Crisis" - has clearly demonstrated a need not only for international political attention and cooperation, but also for greater knowledge of how to integrate refugees in the receiving countries. In order to do so, current integration experience from various receiving countries - including Nordic countries - may prove valuable in understanding the challenges from the perspectives of both the new citizens and the receiving country.

This study focuses on refugees to Denmark and their conditions for obtaining a residence permit, as well as on how successfully they have integrated through labour market participation. Given that the flipside of labour market integration is welfare dependency, the study also focuses on the income transfers that the refugees receive and on how the situation changes with their duration of stay in Denmark. More specifically, the study tracks immigrants who have arrived since 1997, as this is the first year for which it is possible to link information about the basis for permission being granted for residence in Denmark - i.e. whether a given immigrant was granted refugee status, admitted for family reunification, or admitted for work or study - with information from the Danish Central Civil Registration system. This linkage to the administrative data makes it possible to track what happens to immigrants in the years after their arrival.

The question of how immigrants fare on the labour market compared to natives, and the extent to which immigrants' earnings converge with those of natives over the years in step with the increase in their length of stay in the host country is one of the most intensely discussed issues in international migration literature. The first empirical studies were conducted in the United States, where Chiswick (1978) reached the conclusion that the difference between immigrants' and natives' earnings eventually reached parity, and that immigrants' earnings actually overtook those of natives in time. These findings were subsequently corrected by Borjas (1985), who demonstrated that part of the wage difference between immigrants who had been resident in the host country for short and long periods (measured as a cross-section) was in fact attributable to cohort effects. Since then, studies of the assimilation of immigrants into the labour market have been completed in a large number of countries. The general conclusion is that most immigrants face an initial "penalty" in terms of lower employment and earnings. However the issue of whether the assimilation process leads to a closing of 
the initial gap depends to a large extent on the receiving country, the characteristics of the immigrants themselves, and the comparability of the immigrants' skills in the receiving country.

Studies conducted in the Nordic countries include Bratsberg et al. (2014) for Norway, Sarvimäki (2011) for Finland, and Aguilar and Gustafsson (1991), as well as Bevelander and Pendakur (2014), for Sweden. Earlier studies for Denmark (see Husted et al., 2001, Schultz-Nielsen, 2002 and Statistics Denmark, 2015) have clearly shown that immigrants' employment and earnings rise with their length of stay in Denmark. They also reveal that non-Western immigrants fare worse on the Danish labour market than do Western immigrants, in terms both of employment rate and income. In contrast, immigrants from the new EU member states that joined the community subsequent to the eastward expansion of 2004 enjoy high rates of employment. It has also been shown that the rates of employment for refugees in Denmark are lower than for immigrants from other non-Western countries (see Husted et al., 2001; Hansen et al., 2015; Sletting 2015). One analysis distinguishes between refugees and family reunified with refugees, to native Danes and to immigrants (Schultz-Nielsen, 2016), demonstrating that not only refugees, but also family reunified with refugees fare worse on the labour market than other immigrants. This study is a further elaboration on the same data and additionally explores the integration process by focusing on the gap(s) in employment, earnings and transfer income between refugees, other immigrants and natives.

Apart from the international factors that affect the number and composition of immigrants to all receiving countries, Danish experience with integration over the past twenty years should also be viewed in the light of Danish immigration policy and the significant changes to same over the period - for example, when the regulations for being recognised as a refugee or granted admission for family reunification were tightened at the beginning of the 2000s. A brief overview of Danish immigration policy over time is therefore provided in Section 2.2, while Section 2.3 describes the characteristics of the refugees who have arrived since 1997. Section 2.4 explore the gaps in employment, earnings and transfer income, while the conclusions from the analyses are collated in Section 2.5 . 


\subsection{Danish immigration policy and changes in the numbers of newly arrived immigrants}

\subsubsection{Danish immigration policy}

In historical terms, Denmark is a relatively new immigration host country. Up until the mid-1960s, there was overall net emigration from Denmark in most years. Among the immigrants, the majority came from the neighbouring countries of Germany, Sweden, and the other Nordic countries. In addition, there were immigrants from the USA, a country to which many Danes had originally emigrated (Larsen and Matthiessen, 2002).

The introduction of the Nordic passport union in 1954 meant that Denmark had become part of a joint Nordic labour market, with citizens of the Nordic countries now being able to travel, reside and work in all the member states without needing permits. The European Common Market was set up in 1957; Denmark joined in 1973, allowing easy access to the country for labour from other European countries.

The 1960 s were characterised by economic upturns, leading to a shortage of labour and a demand for "guest workers" from countries that included Turkey, Yugoslavia and Pakistan. However, the increasing number of guest workers and the fear of an economic downturn led to a temporary immigrant stop in 1970, followed by an actual ban in 1973. Only citizens of the Nordic and EC countries, and specialist labour for which there was a particular need, were exempted from this prohibition. Labour force immigration from all other countries was no longer permitted. The immigrants who had arrived in Denmark before 1973 were permitted to remain, however. In the subsequent years, the number of non-Western immigrants in Denmark still continued to increase, mostly as a consequence of family reunification, but also because of the admission of a growing number of refugees.

The right of refugees to protection depends on the United Nations 1951 Refugee Convention, which Denmark ratified in 1952 and which thus applied to Denmark from the date it first came into force in 1954. The Refugee Convention protects people who have "a well-founded fear of being persecuted for reasons of race, religion, nationality, membership of a particular social group or political opinion" (for a discussion of the implications of this for Denmark, see Christensen et al., 2000, p. 22). However, not all individuals from other countries who are in need of protection fulfil these precise criteria. A number of countries have therefore introduced supplementary rules to cover such cases. Denmark at various times has defined "B Status", de facto refugee status 
and, most recently, Protection Status (Christensen et al., 2006, p. 298). De facto refugee status was first given in the 1960 s to people who had fled from Communist countries and risked very severe punishment if they returned home, but was later expanded to include people fleeing from active military service (draft resisters or deserters), persecuted homosexuals and various groups fleeing from civil war situations. From 1983 onwards the concept of "de facto refugee status" became enshrined in law in Denmark, and de facto refugees were granted more or less the same rights as Convention refugees. At the same time, it was made more difficult for the authorities to repatriate rejected asylum-seekers, and Denmark acquired "a reputation for leading the way in exercising a humanitarian refugee policy" (Kjær, 2003, p. 18, my translation).

In the beginning of the 1980 s only a modest number of refugees found their way to Denmark, with the majority coming from Vietnam, but the war between Iraq and Iran and the conflicts or states of disorder in countries such as Lebanon, Sri Lanka and Poland forced people to take flight from their homes to destinations overseas that included Denmark. After the introduction of the de facto refugee concept in 1983, the number of people seeking asylum in Denmark increased considerably. The law has been tightened a number of times since then, including the introduction of a procedure to cover "obviously groundless" applications in 1985 . These initiatives regularly led to falls in the number of asylum-seekers, but there were also further increases as a result of new crises arising in the world, and by the end of the 1980s around 5,000 people were seeking asylum in Denmark each year (Matthiessen, 2002). However, this figure increased to around 14,000 people per year in 1992 and 1993 as a result of the civil war in Yugoslavia, and the introduction of special legislation in Denmark in 1993 granted temporary residence specifically to people from the former Yugoslavia, even if they did not fulfil the normal criteria for being granted asylum as laid down in the Aliens Act. In subsequent years the numbers of asylum-seekers fell again, and by the end of the 1990 s they had returned to an annual total of around 5-6,000, primarily from Somalia and Iraq.

Up until 1999 responsibility for integration of immigrants rested with the state, and efforts in this field largely concerned the provision of assistance for newly arrived refugees. In practice, it was the Danish Refugee Council that was responsible for the ${ }_{11 / 2-y e a r}$ integration programme. This consisted primarily of Danish language classes and courses aimed at helping refugees find employment or enter further education. Under the centre-left coalition government at the time, a law was passed in parliament transferring responsibility for the integration programme to local authorities, and the programme was also extended to last three years. The introductory integration 
programme was now offered to all foreign newcomers over the age of 18, except for nationals of EU/EEA countries and their family reunification dependents.

At the same time, a special type of introductory benefit was introduced for people who were covered by the introductory programme. The criteria for receiving this introductory benefit were similar to those for receiving normal social assistance, namely that (a) neither the person in question nor his/her spouse, if any, was in a position to support the family; (b) that no other benefit was available to cover living costs; and (c) that the person had no reasonable offer of employment available. However, people who had come to Denmark for family reunification with a person who was not a refugee were entitled to neither introductory benefit nor normal social assistance, since the terms of admission for family reunification were that the family member already in the country should be able to support the newly arrived family members. ${ }^{9}$ Up until 31 January 2000 the introductory benefit was substantially lower in level than normal social assistance, but it was then raised once again to parity with social assistance because it was decided by the UNHCR that the rule was discriminatory and a breach of the UN Refugee Convention (Hansen and Schultz-Nielsen, 2015).

The requirements for bringing a spouse/cohabiting partner into Denmark were made tougher in June 2000. An "attachment requirement" was introduced, applying initially only to foreign nationals; this requirement stated that the couple's combined level of attachment to Denmark had to be at least as great as their attachment to any other country. ${ }^{10}$ Later, this requirement was raised to a yet higher level, so that the couple's combined level of attachment to Denmark had to be greater than their level of attachment to any other country.

After the accession of a new centre-right government, a number of significant changes were made to legislation regarding both aliens and active social policy, with effect from July 2002. First, it became harder still to qualify for family reunification, with both a toughening of the attachment requirement and the introduction of the "age 24 rule", which required that both spouses/cohabiting partners should have reached 24 years of age before there could be a family reunification. Second, the level of the special introductory benefit for immigrants (or "start help") was cut to below that for normal

9 From 1999 onward the support requirement was removed for Danish citizens, but it was reintroduced in July 2002.

${ }_{10}$ In general, fewer requirements were made of refugees in order to qualify for family reunification (Christensen et al., 2006: 130). This also applied with respect to the "attachment requirement", since refugees seldom had the option of living in their own country of origin. 
social assistance, and the benefit was applicable for all newcomers to the country, whether of Danish or foreign nationality, who had not been resident in Denmark for seven out of the previous eight years. Only nationals of the EU/EEA were exempted from this rule. Third, the de facto refugee status was abolished and replaced by the "B status" concept. This only gave eligibility for residence "if being returned to the home country would place the foreign national at risk of execution or of being subjected to torture or inhuman or degrading treatment or punishment" (Starup 2012, p. 82, my translation). Overall, the effect of these changes was that the possibility of being granted asylum in Denmark was significantly reduced. At the same time, the regulations were eased for immigration to Denmark for study, internships and au-pair work, and new regulations were introduced to attract highly-qualified labour (Hvid et al., 2010).

After 2002 there were further but - except for those related to the expansion of the EU in $2004^{11}$ - less extensive alterations to the Aliens Act. These included changes to the rules for the selection of quota refugees in June 2005, tightening of the rules relating to expulsion of offenders in June 2006, the introduction of an immigration test in connection with family reunification in April 2007, toughening of the rules concerning provisional residence permits for foreign nationals in 2009, and the introduction of an immigration points system that included requirements for foreign spouses in June 2011. After a change of government in 2012 a number of these changes to the law were rescinded, including the points system and the immigration test.

There were also changes in the rules concerning social benefit payments in the period after 2002. First came the introduction of the " 500 kroner rule" for couples (which reduced benefits by DKK 500 per month to each partner) in January 2003, followed in January 2004 by a ceiling for total benefits in the form of social assistance, "start help", introductory benefit, housing benefit and housing supplement. These reductions to benefits were applied to people who had been receiving social assistance for more than six consecutive months (in the case of couples, where at least one member of the couple had been receiving such benefit). The "300 hours rule" was introduced 2006. This only affected couples where both members were receiving social assistance, and meant that benefit was stopped for either member of the couple who had not performed 300 hours of normal

11 In May 2004, ten new countries acceded to membership of the EU. These included Cyprus, Estonia, Latvia, Lithuania, Malta, Poland, Slovakia, Slovenia, the Czech Republic and Hungary. Two additional countries followed in 2007, namely Bulgaria and Romania. After a transitional period (that ended in May 2009) they had rights to free movement within the EU making fewer of them apply for residence through employment, study and family reunification. 
paid work within the previous two years. This could mean a substantial loss of income for those concerned; in practice, many of these couples turned out to be immigrants. The "300 hours rule" was made even more stringent before it was abolished in January 2012, together with introductory benefit/"start help", the "500 kroner rule" and the benefits ceilings. Thus, in 2012 the social assistance system largely reverted to the situation in the mid-1990s (Hansen and Schultz-Nielsen, 2015). After the accession of a new centre-right government in 2015, a new "modern" ceiling for social assistance and a new low-level "integration benefit" were introduced. Generally speaking, these regulations resemble those prior to 2012 and resulted in a severe reduction in benefits; they have also, for example, led to a debate about the possibility of finding sufficient inexpensive housing for newly arrived refugees. However, these changes in the rules took effect too late to affect the analyses presented here.

\subsubsection{Numbers of newly arrived immigrants from 1997 onward}

What have been the trends in the numbers of immigrants coming to Denmark since 1997? The answer can be seen in Figure 1, which shows the annual numbers of immigrants to Denmark in the period $1997-2015$ as listed in Statistics Denmark's records. A given individual may well immigrate more than once to Denmark and thus be counted more than once in the statistics. The figure covers all foreign nationals born outside Denmark with the exception of Nordic citizens, who are entitled to enter and live in Denmark under the terms of the Nordic passport union and who therefore do not need a residence permit. ${ }^{12}$

As shown in the figure, the number of newly arrived immigrants to Denmark rose from 21,900 in 1997 to 27,600 in 2001. There was then a fall in subsequent years, so that the total of 21,600 in 2004 was on a par with that of 1997 . After that, however, the number of newly arrived immigrants each year rose substantially, especially during the period up to 2008 , when 43,400 people immigrated to Denmark. The financial crisis that began in 2008 had a negative effect on employment immigration in particular, and the total number of newly arrived immigrants fell to 38,900 in 2009 before increasing again in subsequent years. In 2015, the last year covered by the statistics, 69,400 foreign nationals (excluding citizens of Nordic countries) immigrated to Denmark.

${ }_{12}$ On average 4,100 newly arrived Nordic citizens were present in Denmark each year in the period from 1997 to 2015 according to the population register by January $15 t$. The lowest number $(3,600)$ was reached in 2002, the highest $(4,800)$ in 2009. 
The figure also shows that the composition of immigration to Denmark has changed significantly over the course of the period covered. Up until and including 2002, family reunification accounted for the largest number of immigrants - one in three of the total. However, this proportion was greatly reduced in subsequent years, in part because the requirements for family reunification became more stringent. The number of refugees, 4, 200 in 1997, also fell, and was especially low in the period 200309, when Denmark received 1,100-1,400 such immigrants annually. This lower total was a consequence of the more stringent requirements to qualify for recognition as a refugee introduced from mid-2002, but was also affected by the fact that the global stream of refugees became smaller in the years after 2002 (Hatton, 2009). From 2010 and onward the number of refugees began to rise again. In 2014 6,100 refugees were granted asylum in Denmark, and in 2015, when the number of people in the world fleeing from their countries had swelled considerably, 10,300 refugees were granted permission to reside in Denmark (see Figure 1). In total, 21,200 asylum seekers were registered in Denmark in 2015 (Udlændinge-, Integrations- og Boligministeriet, 2016). However, these very recently arrived refugees are not included in this analysis, which is primarily concerned with how immigrants fared in the years following their arrival; by definition, this is something that cannot be studied for the newest immigrants. 
Figure 1: Newly arrived immigrants, categorised according to the basis for residence in Denmark, 1997-2015

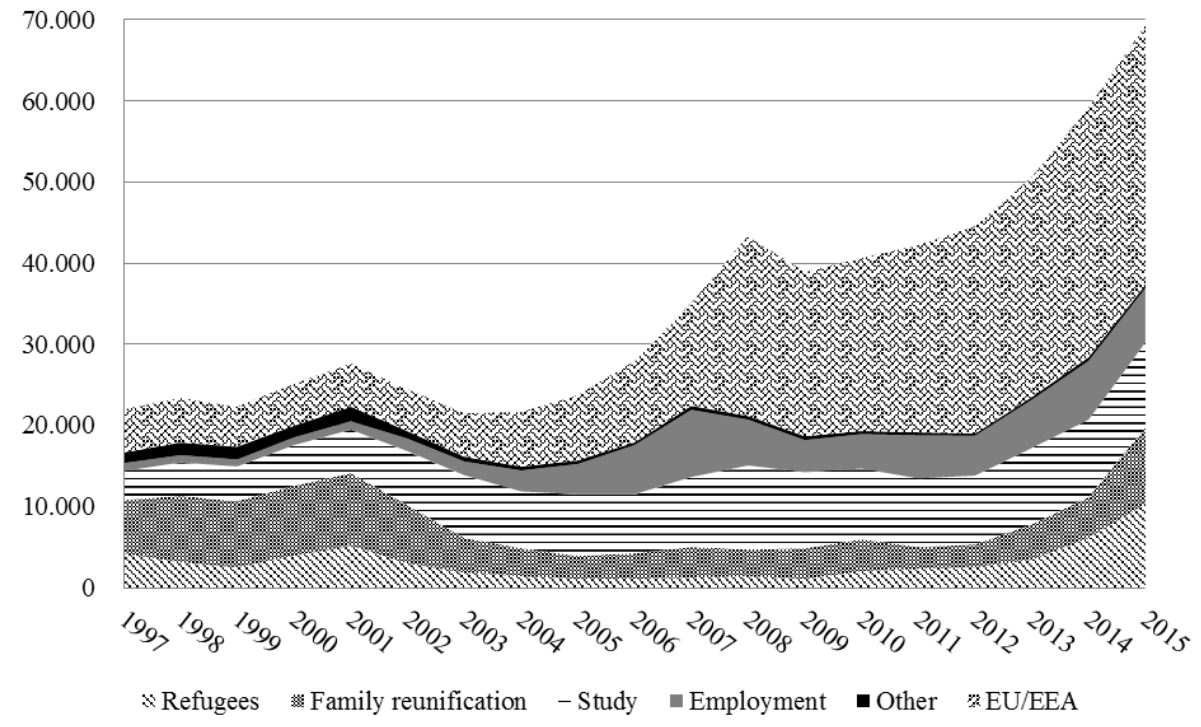

Source: Statistics Denmark, http://www.statistikbanken.dk/VAN8

The number of people coming to Denmark in order to study (including au-pairs) rose from 3,600 in 1997 to 5,400 in 2001. After the lowering of entry requirements for students in 2002, the number increased further to 7,700 in 2003. The same pattern can be seen with respect to work permits. Whereas the number of immigrants of foreign nationality (excluding Nordic and EU/EEA nationals) coming to Denmark for employment purposes was on average around 1,000 per year in the period 1997-2002, the figure had increased to 8,300 in 2007. Subsequently the number fell again to around 4,000 individuals annually before rising once more to 5,900 in 2013. Finally, the figure illustrates that the greatest increase in the number of immigrants up until 2014 occurred as a consequence of the eastward expansion of the EU in 2004. While an average of 5,400 people immigrated to Denmark each year from the EU/EEA countries during the period 1997-2003, with the accession of new member states the number increased substantially, especially after 2007, and in 2015 there were 32,000 immigrants whose residence rights were based on EU/EEA citizenship. 
All in all, the period 1997-2015 witnessed significant changes in the composition of immigrants arriving in Denmark. Before 2003, refugees and reunified family accounted for around half of all new immigrants. The number of refugees and reunified family members subsequently fell sharply, while the number of immigrants on work and education permits rose significantly, such that refugees and reunified family now account for just $15 \%$ of all new immigrants. In the latter part of the period - i.e. after 2011 - the number of refugees and reunified family members rose again, and in 2015 , the number of these immigrants exceeded that from the previous years, although not proportionally, given that refugees and reunified family in 2015 account for close to $30 \%$ of the total number of newly arrived refugees. For 2016 the level is expected to lower again.

\subsection{The characteristics of new immigrants to Denmark in the period 1997-2011}

This study focuses on refugees (including family reunified with refugees) who immigrated to Denmark for the first time in their lives during the period 1997-2011. Information about the basis for the granting of a residence permit to each immigrant was obtained from the Danish Immigration Service. In the case of a person who obtained more than one Danish residence permit on different occasions, or who immigrated to the country more than once, the first basis for granting residence was then used in the study. Foreign nationals other than refugees, family reunified with refugees and family reunified with immigrants, were not included in the statistics.

In the entire period from 1997 to 2011, Statistics Denmark reports that 35,843 refugees entered Denmark - see Figure 1. Of these, it was possible to trace the grounds for residence for 29,915 refugees in the official registers. The difference here is primarily attributable to the fact that in many cases, it was not possible to find correspondence at individual level between the foreign national registration number to which the residence permit is linked and the central registration number (CPR) subsequently issued to the same person, on which all other registers in Denmark are based.

According to the official statistics shown in Figure 1, a total of 78,554 people were granted residence permits for family reunification. The corresponding figure in the registers is 68,586 people, of whom 16,804 immigrated for family reunification with refugees, and 28,046 for reunification with immigrants - a group comprising immigrants and second-generation immigrants who were not refugees. 
In the following section, we examine trends in the patterns of integration over time. We have consequently decided to divide new immigrants into three cohorts, each cohort comprising the immigrants who arrived in one of the periods identified above. The first cohort consists of immigrants who all entered Denmark before the major changes in immigration policy in 2002. This cohort thus comprises the immigrants who arrived during the five calendar years 1997-2001. Immigrants from the next five years (2002-06) make up the second cohort, while the third cohort consists of immigrants who entered the country during the five calendar years 2007-11. The reason for not including more recent immigrants in the analysis is that it is only possible to track them in the records over a limited period after their immigration, because register information was only available up to 2014 .

The sample only covers immigrants between the ages of 17 and 36 years on arrival in Denmark. This age restriction was imposed in order to track the immigration process for immigrants of a fairly similar age on arrival (see Bratsberg et al., 2014; Sarvimäki, 2011). As the later calculations relate to labour market status, only immigrants aged 25 and older are included in the analyses. Because individuals have been tracked for up to 17 years (from 1997 to 2013), this means that none of the immigrants in the analyses are older than $52(36+16)$ and they were all born between 1961 and 1987.

In order to compare immigrants' labour market association and use of social benefits with those of the rest of the population of Denmark, the study also includes a $10 \%$ random sample of all "natives" born between 1961 and 1987.

In all, the sample consists of 307,622 "natives" and 37,645 individuals who immigrated to Denmark for the first time in the period 1997-2011, and they have been tracked in this study in the years following their arrival. ${ }^{13}$ Information concerning their age, gender and civil status has been obtained from Denmark's population register, while information concerning their labour market status, etc. has been retrieved from other records maintained by Statistics Denmark. The main characteristics of the immigrants at time of arrival to Denmark are presented in Table 1 below.

It is possible to retrieve information on all immigrants who were resident in Denmark on 1 January in a given year. The total number of years for which a given individual can be tracked is thus dependent on how early in the research period he or she arrived in Denmark, and how long he or she stayed in the country. This resulted in

\footnotetext{
${ }^{13} \mathrm{~A}$ "native" is here defined according to the definition by Statistics Denmark as a person, who has at least one parent, who is Danish citizen and born in Denmark (Statistics Denmark, 2015).
} 
a dataset comprising 364,583 immigrant observations. By comparison the native sample consists of $3,435,629$ observations.

Table 1: Characteristics of natives, refugees, family reunified with refugees and to (other) immigrants

\begin{tabular}{|c|c|c|c|c|c|c|c|}
\hline & \multirow[t]{2}{*}{ Natives } & \multicolumn{3}{|c|}{ Men } & \multicolumn{3}{|c|}{ Women } \\
\hline & & Refugees & $\begin{array}{r}\text { Family } \\
\text { reunified } \\
\text { to } \\
\text { refugee }\end{array}$ & $\begin{array}{r}\text { Family } \\
\text { reunified } \\
\text { to others }\end{array}$ & Refugees & $\begin{array}{r}\text { Family } \\
\text { reunified } \\
\text { to } \\
\text { refugee }\end{array}$ & $\begin{array}{r}\text { Family } \\
\text { reunified } \\
\text { to others }\end{array}$ \\
\hline Individuals & 307,622 & 9,511 & 1,347 & 5,759 & 4,814 & 6,260 & 9,954 \\
\hline Observations & $3,435,629$ & 96,830 & 13,517 & 52,499 & 48,881 & 68,395 & 84,461 \\
\hline \multicolumn{8}{|l|}{ Cohort $^{1}:$} \\
\hline 1. $(1997-2001)$ & 0.39 & 0.58 & 0.62 & 0.57 & 0.55 & 0.62 & 0.57 \\
\hline 2. $(2002-2006)$ & 0.36 & 0.22 & 0.22 & 0.23 & 0.26 & 0.26 & 0.22 \\
\hline 3. (2007-2011) & 0.32 & 0.20 & 0.16 & 0.20 & 0.19 & 0.12 & 0.22 \\
\hline Non-western & 0.00 & 1.00 & 0.99 & 0.92 & 1.00 & 0.99 & 0.91 \\
\hline $\begin{array}{l}\text { Median age at } \\
\text { immigration }\end{array}$ & - & 28 & 28 & 25 & 28 & 26 & 25 \\
\hline Education unknown & 0.01 & 0.57 & 0.57 & 0.63 & 0.61 & 0.56 & 0.66 \\
\hline Education $<12$ years & 0.23 & 0.18 & 0.20 & 0.14 & 0.22 & 0.25 & 0.14 \\
\hline In DK at least 5 years & 0.98 & 0.95 & 0.91 & 0.85 & 0.94 & 0.96 & 0.83 \\
\hline
\end{tabular}

Note: The mean characteristics are reported based on individuals, not observations.

1: Natives are categorized in birth cohorts matching those of immigrants and that is why the total share $(0.39+0.36+0.32)$ exceeds 1 .

Source: Own calculations based on Statistics Denmark records.

Of the men, 9,511 are refugees, while only 1,347 are family reunited with refugees. On the other hand, only 4,814 refugees are women, while 6,260 are family reunified with refugees. These figures reflect the fact that it is most often men who are refugees, either because they are more likely to attract the unwelcome attention of the authorities in their home countries, or because families decide that men have the best chance of succeeding abroad, and they are therefore sent "in advance".

Note that the family reunification category includes both the spouses of refugees who were married to them before they fled their countries (of origin) and new spouses found by refugees in their home countries after their arrival in Denmark. The sample includes 5,759 men, who are family reunified with immigrants (both first and second generation) who are not refugees, and 9,954 women in a similar situation.

Among refugee men, $58 \%$ belong to the first cohort (those who arrived between 1997 and 2001), while $22 \%$ belong to the second cohort (2003-2006) and $20 \%$ to the 
third cohort (2007-2011). Among the other groups, there is also a clear majority who belongs to the first cohort, and this trait is most pronounced for "family reunified with refugees", where the share is $62 \%$.

It may not be very surprising that so many of the immigrants in the study belong to the first cohort, given that, as shown in Figure 1, the numbers of both newly arrived refugees and reunified family members in Denmark are considerably lower in the years following 2002 most likely due to both changes in the international refugee flows and tightening of the Danish rules for being granted residence as a refugee or family reunified immigrant.

Almost all the refugees and family reunited to refugees are of non-Western origin, while this is the case for $91-92 \%$ of family members reunified with immigrants. ${ }^{14}$ An overview of the most common countries of origin for refugees and family reunified to refugees is found in Table 16. A supplementary report indicates that Iraq, Afghanistan and Somalia are the most common countries of origin among both refugees and family reunified with refugees from cohort 1, and for family reunified with refugees in cohort 2. Refugees from cohort 2 also include a number of quota refugees from Myanmar, while refugees from Iraq and Afghanistan continue to enter Denmark as well. In contrast, it is not until the third cohort that Syria joins the list of most frequent countries of origin among refugees, while Iraq, Somalia and Myanmar continue to dominate the flow of family members reunified with refugees. Refugees and family reunified with refugees thus largely tend to stem from the same countries, although with some periodic staggering, in that refugees have to secure their own residence permit before they can apply for reunification with family members abroad.

This similarity in country of origin for refugees and family reunified with refugees is clearly a consequence of spouses typically originating from the same country. This also emphasises the fact that if a distinction between refugees and other immigrants is based on country of origin instead of actual permit status, it will generally tend to the groups of refugees and family reunified with refugees. These two groups will be combined later on in the present study as well. However, it may be of interest to

${ }_{14}$ Western countries, comprising Andorra, Australia, Canada, Iceland, Liechtenstein, Monaco, New Zealand, Norway, San Marino, Switzerland, USA, the Vatican, Belgium, Cyprus, Denmark, Finland, France, Greece, Ireland, Luxembourg, Malta, the Netherlands, Portugal, Spain, the United Kingdom, Sweden, Germany, Austria, Estonia, Latvia, Lithuania, Slovakia, Slovenia, the Czech Republic, Hungary, Poland, Bulgaria and Romania. Non-Western countries, comprising all other countries not included in the categories of Western countries. 
understand the differences and similarities between the two groups, which is the reason why the two groups have been separated in Table 1.

Family members reunified with other immigrants, on the other hand, typically come from other countries. As Turkish people constitute the largest group of nonWestern immigrants in Denmark, it is hardly surprising that Turkey is also the predominant country of origin among family members reunified with other immigrants in all three cohorts. The other dominant country of origin is Pakistan, which is also regularly represented in all three cohorts.

Among men, the median age for refugees and family reunified with refugees was 28 for both groups, while family members reunified with immigrants tended to be somewhat younger (25). This pattern was partly repeated for women, where the median age for refugees was 28 , while it was 26 for family reunified with refugees and 25 for family reunified with immigrants. A further division by cohorts (not shown here) indicates that the average age for family reunification immigrants increased from 24 to 27 for men from cohort 1 to 2 , and from 24 to 26 for women. The increase in average age for family reunification immigrants may have been due in part to the changes in the rules in 2002, when the "age 24 " rule was introduced, and requirements concerning attachment to Denmark were tightened (Schultz-Nielsen and Tranæs, 2009).

Immigrants' qualifications may, of course, be critical in determining how well they fare on the labour market. Information about their level of education at the time of immigration is thus highly relevant. Unfortunately, the quality of the data on this point is less than optimal. Education completed in Denmark is recorded accurately, but information concerning education obtained in other countries is much harder to come by. That is also why information of educational level is only missing for very few natives. In 2000, Statistics Denmark completed an extensive questionnaire survey centred on education among all immigrants in Denmark, and corresponding surveys were subsequently carried out among newly arrived immigrants (Statistics Denmark, 2000). However, the response rate for the survey was rather low, so the immigrants covered by the study feature a high proportion for whom no information is available concerning the length of their education. No further attempts were made to collect this information after 2004, and Statistics Denmark consequently has no records of education obtained outside Denmark for the most recently arrived immigrants (most of cohort 2 and all of cohort 3 ) in the study. 
The proportion of missing responses is close to $60 \%$ among all the immigrant groups in Table 1. However, for those immigrants where information on length of education on (or shortly after) arrival is available, the proportion with fewer than 12 years of schooling is only $14-25 \%$ compared to $23 \%$ among natives. However as educated immigrants may be more willing to answer such questions this might not be representative for all immigrants.

In the years immediately after arrival, the share of immigrants for whom information about education is available rises somewhat, probably because some immigrants complete an education in Denmark in the intervening period. All in all, however, an additional calculation shows that even after 3 years of stay in Denmark, the proportion with missing educational information is still above $50 \%$, and thereby quite substantial.

Among refugees and family reunified with refugees, the proportion still in Denmark after 5 years is 91 and 96 , respectively against 98 among natives. For family reunification immigrants - men and women - the shares still in the country after five years were 83 and $85 \%$, respectively. In comparison with refugee family members, then, there were somewhat more people in these groups who left Denmark again. There could be several reasons for this, although it seems most likely that for these groups of family reunification immigrants, there are other countries (their home countries) that represent a genuine alternative to living in Denmark. This is rarely the case for members of refugees' families.

Immigrants who have success on the labour market are typically less likely to emigrate later on, and this may lead to bias in the estimated assimilation rates (Edin et al., 2000). This is mostly a problem among labour migrants where the emigration rate is high. In total, however, the numbers who emigrate again among refugees and family reunified to refugees are modest, and a robustness check (excluding immigrants who emigrate within 5 years of stay) show that the results presented in the following section only changes very little by this restriction. Therefore no further attempt has been made in the following analyses to correct for differences over time among those immigrants who remain in Denmark and those who leave the country again. 


\subsection{Labour market participation of new immigrants to Denmark, according to their length of stay}

The following section analyses how the integration of refugees and family members reunified with refugees has progressed over the years following their arrival in Denmark. As mentioned previously, we have chosen to view refugees and family members reunified with refugees as a single group. The reason for this is that the two groups - as shown in Table 1 - share multiple features, including the same country of origin and the fact that their association with the labour market largely follows the same pattern, taking into account differences in gender composition (cf. SchultzNielsen, 2016). ${ }^{15}$ Including reunified family members in the group of refugees also makes the demographic composition of the group more directly comparable with calculations from other countries where information about grounds for residence are not available, and where country of origin therefore has to be used as an indicator of refugee status.

The situation for refugees will in this case be compared with the corresponding status among family members reunified with immigrants who arrived in Denmark during the same period (1997-2011). As mentioned in the previous section, these immigrants are often of Turkish or Pakistani origin. In addition, it is naturally relevant to examine whether labour market participation, etc. approaches the situation for native Danes in the same age group in step with the increasing period of residence. For native Danes, we have therefore chosen to take as our starting point the same birth years (1961-1986) as for the refugees, and to follow them in the period 1997-2011from the year in which they turn 26 - so as to compare the situation for refugees and family members reunified with immigrants with the situation for natives on the labour market. In the same way as in a number of previous studies (Borjas, 1995; Bratsberg et al., 2014), the residence period for natives in this comparison has been approximated to their age minus 25 years.

Given that, as mentioned previously, little information is available concerning the level of education immigrants have brought with them from their home countries, I have chosen instead to make comparisons both with the group of natives as a whole,

${ }^{15} \mathrm{~A}$ robustness check within the current sample shows a similar result. 
and with low-skilled natives, defined here as persons with fewer than 12 years of education. ${ }^{16}$

Figure $2 \mathrm{a}$ and $2 \mathrm{~b}$ below presents the average employment for refugees (including family members reunified with refugees) and family members reunified with other immigrants, by gender and duration of residence. For natives, the graph reflects their average employment from the time they turn 26 , and then presents development for the next 16 years - i.e. until they reach the age of $42 .{ }^{17}$ The figure illustrates the occupational frequency for all natives and for those classified as "low-skilled".

The level of employment is calculated from register-based labour force statistics that also form the basis for the official calculation of the size of the Danish labour force. The point in time at which the situation is measured is the last week in November, when people are categorised in accordance with the normal international (ILO) criteria as being in employment, unemployed, or outside the labour force, with the application of a number of sub-categories (Statistics Denmark, 1999-2013).

Figure 2a shows that, as expected, employment for men is highest among all natives, where employment for the entire period is higher than $80 \%$, but with a rising trend over the first years, probably because many young people completed their education there, after which employment remains at a level close to $90 \%$. Generally speaking, the level of employment thus remains stable at a high level. For low-skilled natives, the rate of employment is significantly lower, although it does develop from a rising level of around $65 \%$ in the first years to $75 \%$ towards the end of the period examined. Among male family members reunified with immigrants the employment rate raises quickly the first years, apparently to almost the same level as low-skilled natives. However, among refugees (including family members reunified with refugees) the employment is very low. On their arrival in Denmark only $6 \%$ of them are in employment. However, it is precisely in the year of arrival that the registration may be a little unsure, and as early as the following year, the rate of employment is somewhat higher, at $21 \%$. The proportion in employment then rises steadily, and after approximately 8 years, it reaches its highest level: around $55 \%$ and thereafter it seems to decline. Therefore, even after 10-15 years of residence, there is still an appreciable gap for refugees up to the employment level not only for natives in general, but also for low-skilled natives and family reunified with immigrants. Among

\footnotetext{
${ }^{16}$ The group therefore does not include persons with high-school or vocational education either.

${ }^{17}$ In the regressions used subsequently natives are included up to the age of 52 , as this is an age limitation that corresponds to that of the refugees.
} 
women in Figure $2 b$ the gap between employment levels for natives and refugees is even more pronounced and employment levels for family reunified to immigrants is much lower than for low-skilled natives. Only $6 \%$ of female refugees is employed the second year after arrival rising to $35 \%$ around the 11th year, where after the employment level seems to stagnate.

Figure 2: Employment rate by origin and number of years of residence in Denmark, \%
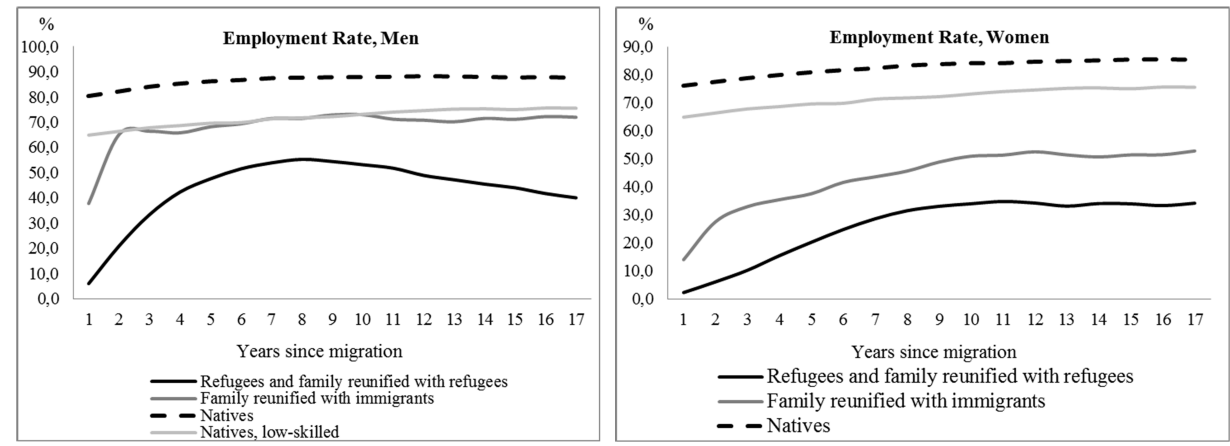

Source: Own calculations based on Statistics Denmark records.

As stated previously, the calculations here are based on all refugees and family members reunified with immigrants who arrived in Denmark between 1997 and 2011, and who were aged 17-36 on arrival. The employment curves presented may therefore also reflect variations in employment that may be attributable to conditions other than simply the change in duration of residence. For example, there may be compositional differences in age and country of origin, as well as differences in conditions at time of arrival and market conditions. In order to make allowance for these differences - to some extent at least - the employment frequency among men and women, respectively, is presented in Appendix Figures 1.1-1.3, divided into three cohorts by time of arrival.

\subsubsection{Employment during the years after arrival in Denmark}

To allow refugees' employment to be compared as far as possible with that of the other groups, the employment gap between refugees, native Danes and family members reunified with immigrants is estimated in Table 2. Here, we have sought to calculate the difference in employment between refugees and "corresponding" natives, taken to 
mean natives with the same demographic features (gender, age, children, etc.), and, to the extent possible, market conditions at the time, but without taking into account differences in educational background. The impact of individual characteristics like the number and age-distribution of children are allowed to differ in the estimations over groups and cohorts. Just like the correction for the business cycle (measured by local unemployment rate) is allowed to differ within groups. The calculation method is described in the Appendix. These estimations show that having small children (o-2 years) in general have a negative effect on women's labour market performance and the effect is more pronounced for all cohorts of refugees and family reunified women than natives. Having (older) children is associated with better labour market performance for natives, but less so for refugees and family reunified to immigrants in general, and especially those with more than 2 children have lower employment level and earnings. In addition, the business cycle fluctuations seem to have a larger effect on the employment of both refugees and family reunified to immigrants compared to all natives. This pattern is less pronounced when comparing immigrants to low-skilled natives. ${ }^{18}$

Table 2 presents the predicted employment differentials between refugees in each of the three cohorts and "corresponding" natives. Recall that it is possible to follow the members of the first cohort for the longest time, and the predicted employment differential here is presented for the second, fifth, tenth and fifteenth years. Over this period, the employment gap for men drops from around 68 percentage points in the second year to around 31 percentage points in the tenth year, after which it appears to rise somewhat again. The employment gap narrows considerably for women the first years, but there continues to be a considerable gap even after 10-15 years. The initial employment gap seems to be smaller for the second cohort than the first, especially for men. However, also for the second cohort of refugee men the employment gap increases after the first years of stay - a path that is confirmed in Appendix Figure 1.2. There are several possible explanations for this path. Some refugees may become discouraged from job search, have health problems or be "forgotten" by the authorities after finishing the initial integration program. In addition labour market conditions for refugees may have changed in recent years, due to increased competition in the job market for low-skilled labour after the EU-enlargement or due to the economic crisis

\footnotetext{
${ }^{18}$ The estimation results are available upon request by the author.
} 
that has left fewer job openings. However, the calculations have been corrected as much as possible for this by including controls for both calendar-year and unemployment rate (by residence type), see appendix A.1 for further details.

As expected the employment gap is smaller when refugees are compared to lowskilled natives, but the evolution of the gap is similar to those among all natives. A comparison of employment among the refugees with "corresponding" family reunified with immigrants also reveals a narrowing of the employment gap, but again for men only during the first years of their stay. As Appendix Figures 1.1-1.3 demonstrate, men in the group of family reunified with immigrants are much quicker to find employment during their first couple of years in the country than refugees, resulting in a substantial initial employment gap.

Table 2: Employment gap between refugees, natives and family reunified with immigrants. (Predicted employment differentials)

\begin{tabular}{|c|c|c|c|c|c|c|c|c|}
\hline \multirow[b]{2}{*}{$\begin{array}{l}\text { Years } \\
\text { since } \\
\text { migration: }\end{array}$} & \multicolumn{4}{|c|}{ Men } & \multicolumn{4}{|c|}{ Women } \\
\hline & 2 & 5 & 10 & 15 & 2 & 5 & 10 & 15 \\
\hline \multicolumn{9}{|c|}{ Refugees vs. natives } \\
\hline 1st cohort & $\begin{array}{r}-0.676 * * * \\
(0.007)\end{array}$ & $\begin{array}{r}-0.436 * * * \\
(0.007)\end{array}$ & $\begin{array}{r}-0.309 * * * \\
(0.006)\end{array}$ & $\begin{array}{r}-0.346 * * * \\
(0.009)\end{array}$ & $\begin{array}{r}-0.776 * * * \\
(0.005)\end{array}$ & $\begin{array}{r}-0.638 * * * \\
(0.005)\end{array}$ & $\begin{array}{r}-0.461 * * * \\
(0.006)\end{array}$ & $\begin{array}{r}-0.421 * * * \\
(0.009)\end{array}$ \\
\hline 2nd cohort & $\begin{array}{r}-0.470 * * * \\
(0.015)\end{array}$ & $\begin{array}{r}-0.257^{* * *} \\
(0.012)\end{array}$ & $\begin{array}{r}-0.308 * * * \\
(0.014)\end{array}$ & & $\begin{array}{r}-0.723^{* * *} \\
(0.010)\end{array}$ & $\begin{array}{r}-0.516 * * * \\
(0.010)\end{array}$ & $\begin{array}{r}-0.434 * * * \\
(0.012)\end{array}$ & \\
\hline 3rd cohort & $\begin{array}{r}-0.606 * * * \\
(0.017)\end{array}$ & $\begin{array}{r}-0.383^{* * *} \\
(0.019)\end{array}$ & & & $\begin{array}{r}-0.702 * * * \\
(0.013)\end{array}$ & $\begin{array}{r}-0.543^{* * *} \\
(0.015)\end{array}$ & & \\
\hline \multicolumn{9}{|c|}{ Refugees vs. Low-skilled natives } \\
\hline 1st cohort & $\begin{array}{r}-0.562 * * * \\
(0.008)\end{array}$ & $\begin{array}{r}-0.298 * * * \\
(0.007)\end{array}$ & $\begin{array}{r}-0.162 * * * \\
(0.007)\end{array}$ & $\begin{array}{r}-0.209 * * * \\
(0.010)\end{array}$ & $\begin{array}{r}-0.545^{* * *} \\
(0.007)\end{array}$ & $\begin{array}{r}-0.379^{* * *} \\
(0.007)\end{array}$ & $\begin{array}{r}-0.188 * * * \\
(0.008)\end{array}$ & $\begin{array}{r}-0.164 * * * \\
(0.010)\end{array}$ \\
\hline 2nd cohort & $\begin{array}{r}-0.33^{* * *} \\
(0.015)\end{array}$ & $\begin{array}{r}-0.096 * * * \\
(0.013)\end{array}$ & $\begin{array}{r}-0.148 * * * \\
(0.015)\end{array}$ & & $\begin{array}{r}-0.462 * * * \\
(0.011)\end{array}$ & $\begin{array}{r}-0.210 * * * \\
(0.011)\end{array}$ & $\begin{array}{r}-0.122 * * * \\
(0.013)\end{array}$ & \\
\hline 3rd cohort & $\begin{array}{r}-0.444^{* * *} \\
(0.018)\end{array}$ & $\begin{array}{r}-0.203^{* * *} \\
(0.019)\end{array}$ & & & $\begin{array}{r}-0.373^{* * *} \\
(0.014)\end{array}$ & $\begin{array}{r}-0.185^{* * *} \\
(0.016)\end{array}$ & & \\
\hline \multicolumn{9}{|c|}{ Refugees vs. family reunification } \\
\hline 1st cohort & $\begin{array}{r}-0.361 * * * \\
(0.014)\end{array}$ & $\begin{array}{r}-0.177^{* * *} \\
(0.011)\end{array}$ & $\begin{array}{r}-0.156 * * * \\
(0.010)\end{array}$ & $\begin{array}{r}-0.235^{* * *} \\
(0.014)\end{array}$ & $\begin{array}{r}-0.165^{* * *} \\
(0.011)\end{array}$ & $\begin{array}{r}-0.124^{* * *} \\
(0.009)\end{array}$ & $\begin{array}{r}-0.125^{* * *} \\
(0.009)\end{array}$ & $\begin{array}{r}-0.165 * * * \\
(0.013)\end{array}$ \\
\hline 2nd cohort & $\begin{array}{r}-0.285^{* * *} \\
(0.022)\end{array}$ & $\begin{array}{r}-0.118 * * * \\
(0.018)\end{array}$ & $\begin{array}{r}-0.188 * * * \\
(0.021)\end{array}$ & & $\begin{array}{r}-0.180 * * * \\
(0.019)\end{array}$ & $\begin{array}{r}-0.132 * * * \\
(0.016)\end{array}$ & $\begin{array}{r}-0.172 * * * \\
(0.018)\end{array}$ & \\
\hline 3rd cohort & $\begin{array}{r}-0.500 * * * \\
(0.026)\end{array}$ & $\begin{array}{r}-0.268 * * * \\
(0.027)\end{array}$ & & & $\begin{array}{r}-0.262 * * * \\
(0.021)\end{array}$ & $\begin{array}{r}-0.242^{* * *} \\
(0.021)\end{array}$ & & \\
\hline
\end{tabular}

Note: Standard errors, clustered within individuals, are reported in parenthesis.

Source: Own calculations based on Statistics Denmark records. 
According to Table 2 the (initial) employment gap for men in third cohort is larger between refugees and family reunified than refugees and low-skilled natives, while the opposite is the case in first cohort. This development might be related to a change in the composition of the group of family reunified after the tightening of the rules for family reunification especially from mid-2002. For women, the employment is low both for refugees and family reunified to immigrants, which explains why the employment differential here generally is smaller and remains relatively constant as time of residence increases.

\subsubsection{Annual earnings during the years after arrival in Denmark}

The gap in annual earnings has likewise been calculated, with the results presented in Table 3. I follow Sarvimäki (2011) and uses the annual earnings (including the zeros) in order to be able to include all. The only group exclude here is the self-employed, as their labour market income is not fully captured by the earnings-measure. Information on earnings is retrieved from the income register, and this refers to the earnings for a given year, regardless of whether they derive from full-time or part-time work, and whether they are for employment over the whole year or only a part of it. Once again, refugees provide the basis for the analysis, where they are compared with "corresponding" natives and family reunified with immigrants. 
Table 3: Predicted earning differentials between refugees, natives and family reunified with immigrants, DKK 1,000 (2015-prices)

\begin{tabular}{|c|c|c|c|c|c|c|c|c|}
\hline \multirow[b]{2}{*}{$\begin{array}{l}\text { Year since } \\
\text { migration: }\end{array}$} & \multicolumn{4}{|c|}{ Men } & \multicolumn{4}{|c|}{ Women } \\
\hline & 2 & 5 & 10 & 15 & 2 & 5 & 10 & 15 \\
\hline \multicolumn{9}{|c|}{ Refugees vs. Natives } \\
\hline 1st cohort & $\begin{array}{r}-259.0 * * * \\
(2.2)\end{array}$ & $\begin{array}{r}-220.6 * * * \\
(2.2)\end{array}$ & $\begin{array}{r}-203.1 * * * \\
(2.7)\end{array}$ & $\begin{array}{r}-227.5^{* * *} \\
(4.0)\end{array}$ & $\begin{array}{r}-169.1 * * * \\
(1.4)\end{array}$ & $\begin{array}{r}-180.3^{* * *} \\
(1.4)\end{array}$ & $\begin{array}{r}-174 \cdot 3^{* * *} \\
(1.8)\end{array}$ & $\begin{array}{r}-173.6 * * * \\
(2.8)\end{array}$ \\
\hline 2nd cohort & $\begin{array}{r}-228.6 * * * \\
(4.3)\end{array}$ & $\begin{array}{r}-157 \cdot 5^{* * *} \\
(4 \cdot 3)\end{array}$ & $\begin{array}{r}-210.5^{* * *} \\
(5.3)\end{array}$ & & $\begin{array}{r}-175 \cdot 9^{* * *} \\
(2.2)\end{array}$ & $\begin{array}{r}-167.5^{* * *} \\
(2.3)\end{array}$ & $\begin{array}{r}-177 \cdot 3^{* * *} \\
(3.2)\end{array}$ & \\
\hline 3rd cohort & $\begin{array}{r}-255 \cdot 5^{* * *} \\
(4.0)\end{array}$ & $\begin{array}{r}-231.2 * * * \\
(5.2)\end{array}$ & & & $\begin{array}{r}-187.9^{* * *} \\
(2.3)\end{array}$ & $\begin{array}{r}-193.4 * * * \\
(2.9)\end{array}$ & & \\
\hline \multicolumn{9}{|c|}{ Refugees vs. Low-skilled natives } \\
\hline 1st cohort & $\begin{array}{r}-206.6 * * * \\
(2.6)\end{array}$ & $\begin{array}{r}-136.6 * * * \\
(2.6)\end{array}$ & $\begin{array}{r}-87.3 * * * \\
(3.0)\end{array}$ & $\begin{array}{r}-91.0 * * * \\
(4.2)\end{array}$ & $\begin{array}{r}-115 \cdot 3^{* * *} \\
(1.9)\end{array}$ & $\begin{array}{r}-93.0 * * * \\
(1.8)\end{array}$ & $\begin{array}{r}-54.8 * * * \\
(2.3)\end{array}$ & $\begin{array}{r}-42.4 * * * \\
\text { (3.2) }\end{array}$ \\
\hline 2nd cohort & $\begin{array}{r}-166.3 * * * \\
(4.5)\end{array}$ & $\begin{array}{r}-63.2 * * * \\
(4.5)\end{array}$ & $\begin{array}{r}-75.8 * * * \\
(5.5)\end{array}$ & & $\begin{array}{r}-111.0 * * * \\
(2.5)\end{array}$ & $\begin{array}{r}-59.6 * * * \\
(2.7)\end{array}$ & $\begin{array}{r}-35.2 * * * \\
(3.6)\end{array}$ & \\
\hline 3rd cohort & $\begin{array}{r}-174.0 * * * \\
(4.2)\end{array}$ & $\begin{array}{r}-113.0 * * * \\
(5.4)\end{array}$ & & & $\begin{array}{r}-90.2 * * * \\
(2.8)\end{array}$ & $\begin{array}{r}-56.4^{* * *} \\
(3.3)\end{array}$ & & \\
\hline \multicolumn{9}{|c|}{ Refugees vs. family reunification } \\
\hline 1st cohort & $\begin{array}{r}-84.7 * * * \\
(4.1)\end{array}$ & $\begin{array}{r}-47.2 * * * \\
(3.8)\end{array}$ & $\begin{array}{r}-44.6 * * * \\
(4.3)\end{array}$ & $\begin{array}{r}-64.1 * * * \\
(6.3)\end{array}$ & $\begin{array}{r}-20.8 * * * \\
(2.7)\end{array}$ & $\begin{array}{r}-18.4 * * * \\
(2.2)\end{array}$ & $\begin{array}{r}-28.6 * * * \\
(2.7)\end{array}$ & $\begin{array}{r}-47.8 * * * \\
(4.3)\end{array}$ \\
\hline 2nd cohort & $\begin{array}{r}-81.2 * * * \\
(7.1)\end{array}$ & $\begin{array}{r}-34.5 * * * \\
(7.1)\end{array}$ & $\begin{array}{r}-61.0 * * * \\
(8.5)\end{array}$ & & $\begin{array}{r}-27.5^{* * *} \\
(4.3)\end{array}$ & $\begin{array}{r}-21.6 * * * \\
(3.9)\end{array}$ & $\begin{array}{r}-44.0 * * * \\
(5.1)\end{array}$ & \\
\hline 3rd cohort & $\begin{array}{r}-122.6 * * * \\
(7.2)\end{array}$ & $\begin{array}{r}-89.1 * * * \\
(8.4)\end{array}$ & & & $\begin{array}{r}-44 \cdot 3^{* * *} \\
(4.0)\end{array}$ & $\begin{array}{r}-49.8 * * * \\
(4.2)\end{array}$ & & \\
\hline
\end{tabular}

Note: Standard errors, clustered within individuals, are reported in parenthesis.

Source: Own calculations based on Statistics Denmark records.

The gap in earnings between refugees and natives is significant among men - on average more than DKK 225,000 the second year - and, as mentioned, covers differences in hourly wage and the number of hours worked during the year. However, even after ten years in Denmark, the earnings gap appears to have only slightly decreased, even though employment among refugees generally improves with the length of stay. At the same time, however, "corresponding" natives experience an increase in earnings as their careers progress and their seniority (and age) rises - an increase not mirrored among refugees, cf. Appendix Figure 1. It is likely that at least part of the explanation for this is linked to the level of education. An examination of the earnings gap between refugees and low-skilled natives reveals that the difference in earnings is significantly smaller, and that it is reduced even further with the rise in time 
of residence. The figures for women indicate a corresponding tendency in development over time in the earnings gap between refugees and natives, although the differences generally appear to be a little smaller than those for men.

The earnings gap between refugees and family reunified with immigrants is smaller than for low-skilled people. The earnings differences seem to narrow for men between the second and fifth year in all three cohorts, but for the first cohort they seem to rise again after the tenth year and for the second cohort after the fifth year. This development appears to be replicated for women. The pattern here calls to mind the development in the employment gap, and is probably heavily influenced by differences in the level of employment, and thus on the number of hours worked.

A related question to the earnings gap is where refugees are represented in the overall earnings distribution of natives. A supplementary calculation for the refugees arrived from 1997 to 2011 shows that among men the average percentile for refugees is 22 against 15 for women. If persons without earnings are excluded the average percentile rises to 26 for both refugee men and women and it clearly underlines that refugees are overrepresented in the bottom of the earnings distribution.

\subsubsection{Transfer income during the years after arrival in Denmark}

The extent to which new immigrants received transfers from the state has also been analysed. Information concerning transfer incomes has been retrieved from both income and social assistance registers, and covers all types of social assistance, job support, rehabilitation benefit, unemployment pay, student maintenance grants, housing benefit, child allowances and disability pension. Transfers are calculated on an annual basis for all new immigrants, regardless of employment status, and include both taxable and tax-free payments. The amounts are expressed in 2015 prices.

The predicted differentials in transfer income are presented in Table 4. As expected on the basis of the differences demonstrated in employment and earnings, refugees consistently receive more transfers than natives in general. Particularly for the first cohort, the level is much higher (approx. DKK 100,000) to start with, although the level does appear - as expected - to fall steadily in step with increased time of residence, in any case up to the tenth year of residence. The transfer gap is generally narrower for the second cohort, for both women and men. This may be because the employment gap shown in Table 2 is smaller in the second cohort, but it may also be attributable to the introduction of the "start help" mentioned previously, which, for new arrivals, 
entailed a significant reduction in social benefits in the event of unemployment during the first seven years of their residence. The regulations were in force from the middle of 2002 until the end of 2011.

As expected, a comparison with low-skilled natives reveals a significantly smaller difference in the transfer income gap. Here, too, the gap is smaller for women than for men, and for cohort 2, the difference appears to be negative - perhaps on account of the afore-mentioned "start help". Compared with family members reunified with immigrants, refugees receive most in the period as a whole. This may be due to the difference in their labour market association, but could equally be attributable to people entering Denmark on family reunifications (with others than refugees) being entitled to fewer social benefits, especially during the first few years, because their residence permit is fundamentally conditional upon the capacity of their spouse to support them. 
Table 4: Predicted difference in transfer income between refugees, natives and family reunified with immigrants, DKK 1,000 (2015-prices)

\begin{tabular}{|c|c|c|c|c|c|c|c|c|}
\hline \multirow[b]{2}{*}{$\begin{array}{l}\text { Year since } \\
\text { migration: }\end{array}$} & \multicolumn{4}{|c|}{ Men } & \multicolumn{4}{|c|}{ Women } \\
\hline & 2 & 5 & 10 & 15 & 2 & 5 & 10 & 15 \\
\hline \multicolumn{9}{|c|}{ Refugees vs. Natives } \\
\hline 1st cohort & $\begin{array}{r}106.3^{* * *} \\
(1.2)\end{array}$ & $\begin{array}{r}79.7^{* * *} \\
(1.0)\end{array}$ & $\begin{array}{r}54.1 * * * \\
\text { (1.1) }\end{array}$ & $\begin{array}{r}60.5^{* * *} \\
(1.7)\end{array}$ & $\begin{array}{r}91.6 * * * \\
(1.1)\end{array}$ & $\begin{array}{r}90.2 * * * \\
(1.0)\end{array}$ & $\begin{array}{r}71.0 * * * \\
(1.1)\end{array}$ & $\begin{array}{r}69.7^{* * *} \\
(1.6)\end{array}$ \\
\hline 2nd cohort & $\begin{array}{r}69.1 * * * \\
(2.0)\end{array}$ & $\begin{array}{r}40.3^{* * *} \\
(1.7)\end{array}$ & $\begin{array}{r}55 \cdot 5^{* * *} \\
(2.4)\end{array}$ & & $\begin{array}{r}38.4 * * * \\
(1.9)\end{array}$ & $\begin{array}{r}34.4 * * * \\
(1.7)\end{array}$ & $\begin{array}{r}56.4 * * * \\
(2.0)\end{array}$ & \\
\hline 3rd cohort & $\begin{array}{r}75 \cdot 7^{* * *} \\
(2.1)\end{array}$ & $\begin{array}{r}54.2 * * * \\
(2.4)\end{array}$ & & & $\begin{array}{r}38.2 * * * \\
(2.9)\end{array}$ & $\begin{array}{r}52.2 * * * \\
(2.8)\end{array}$ & & \\
\hline \multicolumn{9}{|c|}{ Refugees vs. Low-skilled natives } \\
\hline 1st cohort & $\begin{array}{r}90.9^{* * *} \\
(1.3)\end{array}$ & $\begin{array}{r}56.7^{* * *} \\
(1.1)\end{array}$ & $\begin{array}{r}26.6 * * * \\
(1.2)\end{array}$ & $\begin{array}{r}32.6 * * * \\
(1.8)\end{array}$ & $\begin{array}{r}53.4^{* * *} \\
(1.4)\end{array}$ & $\begin{array}{r}43.6 * * * \\
(1.3)\end{array}$ & $\begin{array}{r}20.3^{* * *} \\
(1.4)\end{array}$ & $\begin{array}{r}21.3^{* * *} \\
\text { (1.9) }\end{array}$ \\
\hline 2nd cohort & $\begin{array}{r}50.8 * * * \\
(2.0)\end{array}$ & $\begin{array}{r}12.9^{* * *} \\
(1.8)\end{array}$ & $\begin{array}{r}23.6 * * * \\
(2.5)\end{array}$ & & $\begin{array}{l}-4.4^{*} \\
(2.2)\end{array}$ & $\begin{array}{r}-21.6 * * * \\
(1.9)\end{array}$ & $\begin{array}{r}-3.5 \\
(2.3)\end{array}$ & \\
\hline 3rd cohort & $\begin{array}{r}50.5^{* * *} \\
(2.2)\end{array}$ & $\begin{array}{r}21.2 * * * \\
(2.5)\end{array}$ & & & $\begin{array}{r}-19.5 * * * \\
(3.0)\end{array}$ & $\begin{array}{r}-16.0 * * * \\
(3.0)\end{array}$ & & \\
\hline \multicolumn{9}{|c|}{ Refugees vs. family reunification } \\
\hline 1st cohort & $\begin{array}{r}76.9 * * * \\
(1.9)\end{array}$ & $\begin{array}{r}48.2 * * * \\
(1.5)\end{array}$ & $\begin{array}{r}34.1 * * * \\
(1.6)\end{array}$ & $\begin{array}{r}46.2 * * * \\
(2.4)\end{array}$ & $\begin{array}{r}93.6 * * * \\
(1.9)\end{array}$ & $\begin{array}{r}64.2 * * * \\
(1.6)\end{array}$ & $\begin{array}{r}40.6 * * * \\
(1.6)\end{array}$ & $\begin{array}{r}41.6 * * * \\
(2.2)\end{array}$ \\
\hline 2nd cohort & $\begin{array}{r}68.3^{* * *} \\
(2.7)\end{array}$ & $\begin{array}{r}29.5^{* * *} \\
(2.4)\end{array}$ & $\begin{array}{r}43.6 * * * \\
(3.2)\end{array}$ & & $\begin{array}{r}67.7^{* * *} \\
(3.1)\end{array}$ & $\begin{array}{r}34.4 * * * \\
(2.9)\end{array}$ & $\begin{array}{r}36.6 * * * \\
(3.0)\end{array}$ & \\
\hline 3rd cohort & $\begin{array}{r}90.5^{* * *} \\
(2.7)\end{array}$ & $\begin{array}{r}45.1 * * * \\
(3.3)\end{array}$ & & & $\begin{array}{r}82.2 * * * \\
(3.5)\end{array}$ & $\begin{array}{r}64.9 * * * \\
(3.4)\end{array}$ & & \\
\hline
\end{tabular}

Note: Standard errors, clustered within individuals, are reported in parenthesis.

Source: Own calculations based on Statistics Denmark records.

Taken together, Tables 2-4 paint a picture of refugees as the most poorly placed group on the Danish labour market. They are more rarely in employment and their earnings are lower than those of the other groups. This is offset to an extent by higher transfer incomes - in any case during the periods in which a special, low social benefit-like payment for new arrivals was not in effect. 


\subsubsection{Immigrants' integration and fiscal sustainability}

As demonstrated in this study, a little more than $40 \%$ of refugees are in employment after ten years in Denmark, their average earnings are lower and they receive more transfer income than natives. This situation has serious consequences, not only on the living conditions of the individual refugee, but also - if the flow of refugees reaches a considerable size - for the public finances. In this context, it is important to bear in mind that refugees have not come to the country to benefit the public finances, but because they are in dire need of humanitarian protection. Nevertheless, it may be relevant to ask how high employment among refugees needs to be for their total net contribution to become neutral. This naturally depends on a large number of conditions, including their family situation, their wages while they are in employment, and their age on arrival. A new study based on the general equilibrium model - DREAM - that is used to calculate financial political sustainability in a wide range of Danish surveys indicates that non-Western immigrants who arrive in Denmark as 30-year-olds constitute expense-neutral immigration once their rate of employment reaches approximately $65 \%$, cf. Skaksen and Jensen(2016). In relation to a discussion about the employment gap, it is therefore worth noting that the employment requirement for first generation immigrants is thus somewhat lower than for Natives, where the requirement $(76 \%)$ is close to the current level of employment; this is due in particular to the fact that refugees whose average age on arrival in Denmark is approximately 28 , do not have to have their childhood expenses covered, i.e. the cost of day-care and schooling. In contrast, it is undeniable that there is a long way indeed from the current level of employment for refugees and the $65 \%$ cited.

\subsection{Conclusion}

This analysis examines refugees' association with the labour market in Denmark from the end of the 1990 s to the present day. The flow of refugees varies significantly over time and this development both reflects the changing global flows of refugees and the more stringent requirements to qualify for recognition as a refugee from mid-2002 in Denmark. At the start of the period (1997), 4, 200 refugees arrived in Denmark, and this figure remained relatively high until 2001, after which the numbers fell and continued to do so until 2005, when the annual flow was below 1,200. After 2006, the number of 
refugees rose again until 2015, when 10,300 refugees were granted residence permits in Denmark.

In order to examine the assimilation of refugees into the Danish labour market, the study traced everyone who arrived in the period 1997 to 2011 and was registered with a residence permit as a refugee or a family member reunified with a refugee. The conditions for refugees and their family members are then compared not only to those of natives, but also to family members reunified with non-refugee immigrants who arrived during the same period. The results demonstrate that even though refugees (and their family members) in general improve their labour market participation within the first years of their stay in Denmark they do not catch up with neither natives (all or low-skilled) nor family reunified with immigrants and after a decade they seem to fall behind. As a consequence refugees have received higher transfer income than the other groups - but less so in the period where the lower introductory benefit ("start help") was in force.

The poor labour market attachment of refugees in Denmark suggests that it is highly important not only to improve the integration of newly arrived refugees, but also to maintain a focus on their situation later on in order to secure that they can retain or improve their labour market attachment.

\section{References}

Aguilar, R., and B. Gustafsson. (1991). The Earnings Assimilation of Immigrants. Labour 5 (2), 37-58. https://doi.org/10.1111/j.1467-9914.1991.tbooo36.x

Andersen, L. H., H. Hansen, M. L. Schultz-Nielsen and T. Tranæs. (2012). Starthjælpens betydning for flygtninges levevilkår og beskæftigelse. Rockwool Foundation Research Unit, Study paper no. 25.

Åslund, O. and Rooth, D.O. (2007). Do when and where matter? Initial labour market conditions and immigrants earnings. Economic Journal, 117 (518), 422-48. https://doi.org/10.1111/j.14680297.2007.02024.X

Bevelander, P. and R. Pendakur. (2014). The labour market integration of refugee and family reunion immigrants: a comparison of outcomes in Canada and Sweden. Journal of Ethnic and Migration Studies 40 (5), 689-709. https://doi.org/10.1080/1369183X.2013.849569

Borjas, G. J. (1985). Assimilation, Changes in Cohort Quality and the earnings of immigrants. Journal of Labor Economics 3 (4), 463-489. https://doi.org/10.1086/298065

Borjas, G. J. (1995). Assimilation, Changes in Cohort Quality revisited: what happened to earnings in the 1980s? Journal of Labor Economics 13 (2), 201-245.

https://doi.org/10.1086/298373 
Borjas, G. J. (1999). The Economic Analysis of Immigration. Chapter 28 in Ashenfelter and Card (eds.), Handbook of Labor Economics. Elsevier Science, 1698-1760.

https://doi.org/10.1016/s1573-4463(99)03009-6

Bratsberg, B., O. Raaum and K. Røed (2014). Immigrants, Labour Market Performance and Social Insurance. The Economic Journal 124, 644-683. https://doi.org/10.1111/ecoj.12182

Chiswick, B.R. (1978). The Effect of Americanization on the Earnings of Foreign-born Men. Journal of Political Economy, 86(5), 897-921. https://doi.org/10.1086/260717

Christensen, L.B., N.E. Hansen, G. Homann, E. B. Jørgensen, K. Kjær, M. Kjærum, I. E. Koch, N. Lassen, J. Vedsted-Hansen and L. Wendland. (2000). Udlændingeret. Jurist- og

Økonomforbundets Forlag, Copenhagen.

Christensen, L.B., K. Hallberg, G. Homann, K. Kjær, M. Kjærum, I. E. Koch, N. Lassen, P. B. Mikkelsen, H. Thomassen, J. Vedsted-Hansen and L. Wendland. (2006). Udlændingeret. Juristog Økonomforbundets Forlag, Copenhagen.

Edin, P.A., R.J. LaLonde and O. Åslund. (2000). Emigration of immigrants and measures of immigrants assimilation: Evidence from Sweden. Swedish Economic Policy Review, 7, 163-204.

Hansen, H. and M. L. Schultz-Nielsen. (2015). Kontanthjælpen i Danmark-Modtagere, regler, incitamenter og levevilkår fra 1987 til 2012. Gyldendal, Copenhagen.

Hansen, M. F., M. L. Schultz-Nielsen and T. Tranæs. (2015). The Impact of Immigrants on Public Finances: A Forecast Analysis for Denmark. Rockwool Foundation Research Unit, Study Paper no. 90.

Hatton, T. J. (2009). The Rise and Fall of Asylum: What happened and why? The Economic Journal, 119, 183-213. https://doi.org/10.1111/j.1468-0297.2008.02228.x

Husted, L., H. S. Nielsen, M. Rosholm and N. Smith. (2001). Employment and Wage Assimilation of Male First-Generation Immigrants in Denmark. International Journal of Manpower, 22, 39-68. https://doi.org/10.1108/01437720110386377

Hvid, K. F. W. Jensen, K. Olesen and M.A. Flyvholm. (2010). Rekruttering af udenlandsk arbejdskraft: Indvandreres arbejdsmiljø og tilknytning til arbejdsmarkedet. Det Nationale Forskningscenter for Arbejdsmiljø, Copenhagen

Kjær, K.U. (2003). Flygtninge i Danmark - En kommenteret introduktion til det danske asylsystem. Akademisk Forlag, Copenhagen.

Larsen, C. and P.C. Matthiessen. (2002). Indvandrerbefolkningens sammensætning og udvikling i Danmark. Chapter 1 in G.V. Mogensen and P.C. Matthiessen (eds), Indvandrerne og arbejdsmarkedet. Spektrum, Copenhagen.

Matthiessen, P.C. (2002). Befolkning og Samfund. Handelshøjskolens Forlag, Copenhagen.

Sarvimäki, M. (2011). Assimilation to a Welfare State: Labor Market Performance and Use of Social Benefits by Immigrants to Finland. Scandinavian Journal of Economics 113 (3), 665-688. https://doi.org/10.1111/j.1467-9442.2011.01652.x

Schultz-Nielsen, M.L. (2002). Indvandrernes tilknytning til arbejdsmarkedet 1985-2001. Chapter 2 in G.V. Mogensen and P.C. Matthiessen (eds), Indvandrerne og arbejdsmarkedet. Spektrum, Copenhagen. 
Schultz-Nielsen, M.L. and T. Tranæs. (2009). AEgteskabsmønsteret for unge med indvandrerbaggrund: Konsekvenser af ændringer i udlændingeloven i 2000 og 2002. Rockwool Foundation Research Unit, Study paper no. 22.

Schultz-Nielsen, M.L. (2016). Arbejdsmarkedstilknytningen for flygtninge og indvandrere.

Rockwool Foundation Research Unit. The University Press of Southern Denmark, Odense.

Sletting, L. J. (2015). Her fjerde flygtning er i job efter 10 år. Agenda, 7 March 2015.

Skaksen, J. R. and B. Jensen. (2016). Hvad ved vi om indvandring og integration? Rockwool

Foundation Research Unit and Gyldendal, Copenhagen.

Starup, Peter. (2012). Grundlæggende udlændingeret I. Jurist- og Økonomforbundets Forlag, Copenhagen.

Statistics Denmark. (1999-2013). Registerbaseret arbejdsstyrkestatistik 1. januar. Statistiske Efterretninger, Arbejdsmarked. Copenhagen.

Statistics Denmark. (2000). Indvandrernes uddannelse. Copenhagen.

Statistics Denmark. (2015). Indvandrere i Danmark 2015. Copenhagen.

Udlændinge-, Integrations- og Boligministeriet. (2016). Tal på udlændingeområdet pr. 31.12.2015. Copenhagen. 


\section{Appendix}

\section{A.1 The model}

This section presents the model used to estimate the predicted differences in labour market outcomes presented in section 4. This model is based on the analytical framework described in Borjas (1999).

The dependent variables ( $\left.Y_{i t}\right)$ in the analysis are, in turn, employment (o/1), annual earnings (DKK) and annual transfer income. The binary outcome (employment) is estimated using a logistic regression, while ordinary least squares is used when estimating the earnings and transfer income regressions.

The dependent variable is calculated for each person $i$ at time $t$. It is thus possible for the same person to be included in the calculations several times as there is one observation for each year.

For immigrants the estimation equation is defined as:

A1

$$
\begin{aligned}
& Y_{i t}=\beta_{0}+\beta_{1 g r} g r_{i}+\beta_{2 g r} y s m_{i t}+\beta_{3 g r} a g e_{i t}+\beta_{4 g r} X_{i t}+\beta_{5 r e s} U_{l t}+ \\
& \beta_{6} C_{t}+\varepsilon_{i t}
\end{aligned}
$$

The two categories of basis for residence ( $1=$ refugees and $2=$ family reunified to immigrants) are here labelled "resi", and they can be divided into three cohorts (cohi) giving a total of six groups ( $\mathrm{gr}_{\mathrm{i}}$ ). The independent variables also include duration of residence in Denmark (ysmit) as third degree polynomials and age (ageit) as fourth degree polynomials. $X_{i t}$ is a vector of demographic characteristics and includes dummies for having small children under the age of two ( $0=$ no, $1=y e s$ ), having 1-2 children (0/1), having 3-5 (0/1) and having 6 children or more $(0 / 1)$. The local unemployment rate $U_{l t}$ in the community $l$ is also included, just like dummies for each calendar year $C_{t}$.

For natives the corresponding equation is:

A2

$$
Y_{i t}=\beta_{0}+\beta_{30} a g e_{i t}+\beta_{40} X_{i t}+\beta_{50} U_{l t}+\beta_{6} C_{t}+\varepsilon_{i t}
$$

Please note that this specification allows the coefficients regarding age, year since migration, demographic characteristics and local unemployment rate to vary between the groups, while the calendar year effect is assumed to be fixed across groups 
(including natives) in order to disentangle the effect of age and years since migration (by cohort) from calendar year effects. For a formal discussion of the identification problem when measuring immigrant assimilation see Borjas (1999).

Based on the jointly estimated regressions of $A_{1}$ and $A_{2}$ the outcome gaps are predicted in three situations comparing refugees (based on own characteristics) with: family reunified, all natives and low skilled natives (based on refugees characteristics). Separate regressions are run by gender.

\begin{tabular}{|c|c|c|c|}
\hline & Cohort 1 & Cohort 2 & Cohort 3 \\
\hline \multirow[t]{5}{*}{ Men } & Iraq (38\%) & Iraq $(18 \%)$ & Syria (19\%) \\
\hline & Afghanistan (16\%) & Myanmar (10\%) & $\operatorname{Iran}(16 \%)$ \\
\hline & Somalia (14\%) & $\operatorname{Iran}(10 \%)$ & Afghanistan (15\%) \\
\hline & Bosnia and Herzegovina (6\%) & Afghanistan (10\%) & $\operatorname{Iraq}(15 \%)$ \\
\hline & Former Yugoslavia (4\%) & Somalia ( $9 \%)$ & Myanmar (8\%) \\
\hline \multirow[t]{5}{*}{ Women } & Iraq $(30 \%)$ & Iraq $(25 \%)$ & $\operatorname{Iraq}(16 \%)$ \\
\hline & Somalia (19\%) & Myanmar (17\%) & Afghanistan (15\%) \\
\hline & Afghanistan (13\%) & Somalia (10\%) & Myanmar (13\%) \\
\hline & Bosnia and Herzegovina (6\%) & Bosnia and Herzegovina ( $7 \%)$ & Syria $(8 \%)$ \\
\hline & $\operatorname{Iran}(4 \%)$ & $\operatorname{Iran}(6 \%)$ & Iran (8\%) \\
\hline
\end{tabular}

Note: ${ }^{1}$ Includes both refugees and family reunified to refugees.

Source: Own calculations based on Statistics Denmark records. 
Appendix Figure 1.1: Employment rate, annual earnings and transfer income, cohort 1
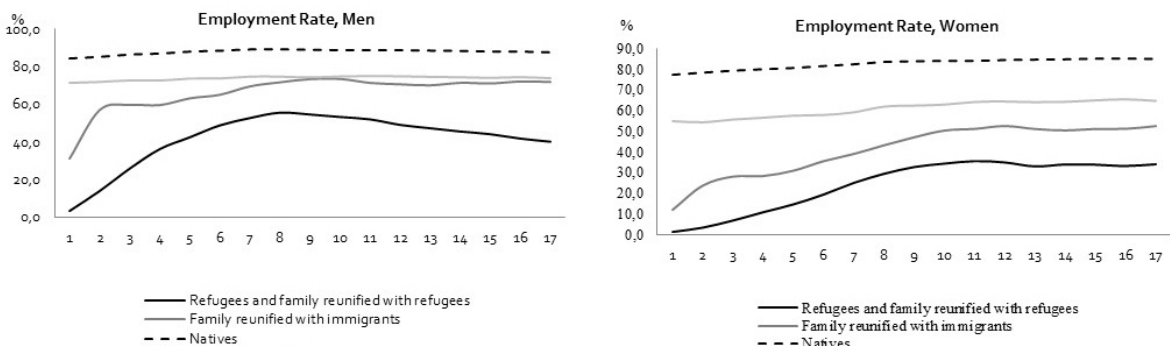

- - Natives

Natives, low-skilled

Refugees and family reunified with refugees - Family reunified with im migrants

- - Natives

-Natives, low-skille

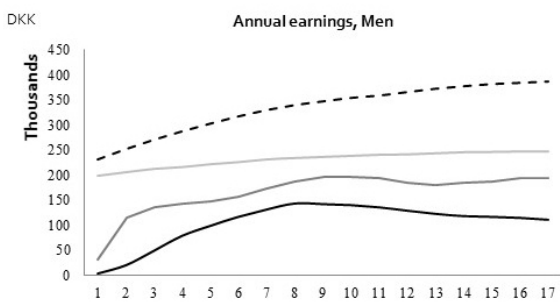

DKK

Annual earnings, Women
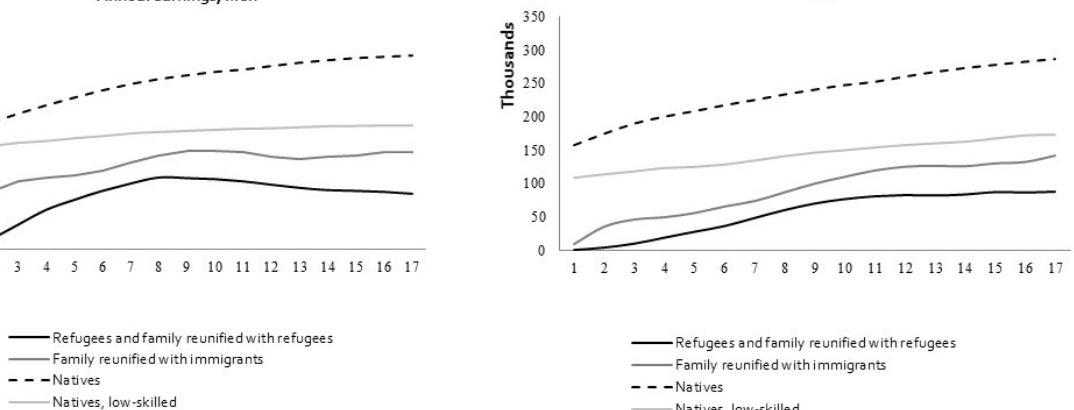

Refugees and family reunified with refugee - Family reunified with immigrants - - - Natives

Natives, low-skilled
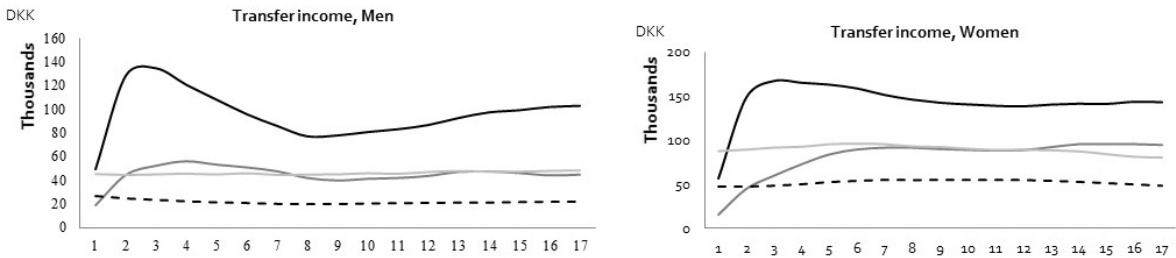

- Refugees and family reunified with refugees Family reunified with immigrants - - - Natives

Natives, low-skilled

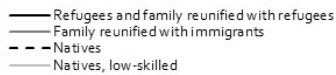

Source: Own calculations based on Statistics Denmark records. 


\section{Appendix Figure 1.2: Employment rate, annual earnings and transfer income, cohort 2}
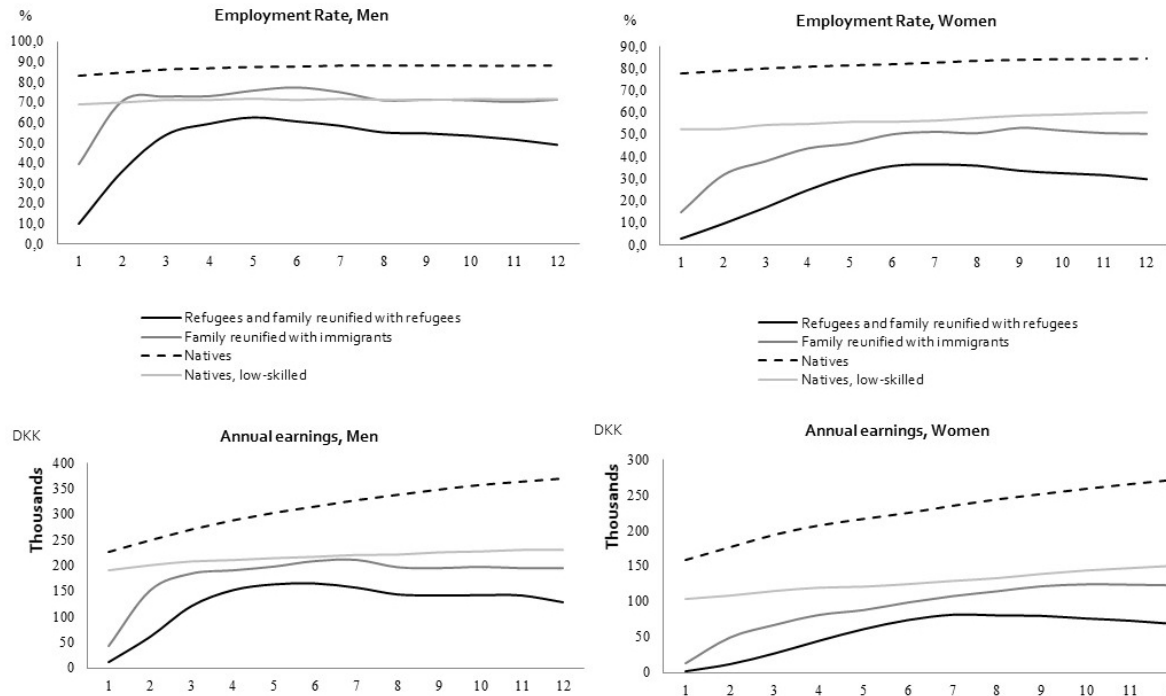

DKK Annual earnings, Women
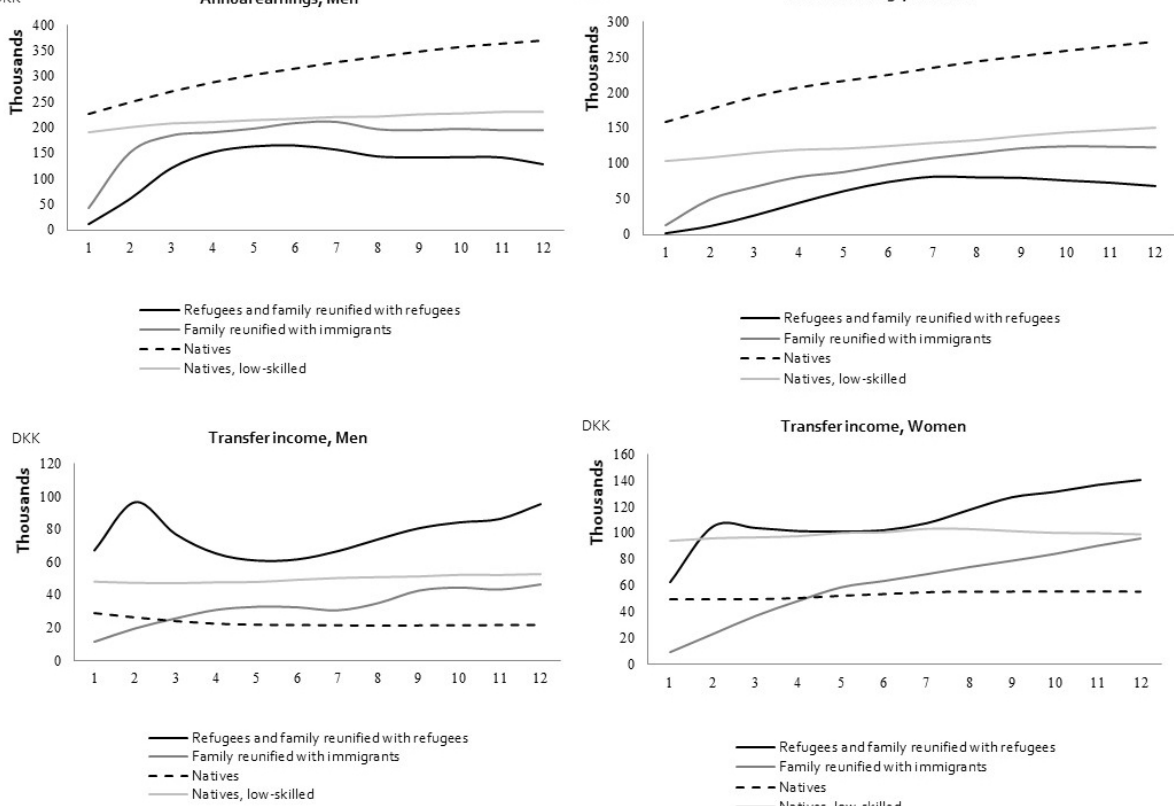

- Refugees and family reunified with refugee Family reunified with immigrants - - Natives

Natives, low-skilled

Natives, low-skilled 


\section{Appendix Figure 1.3: Employment rate, annual earnings and transfer income, cohort 3}
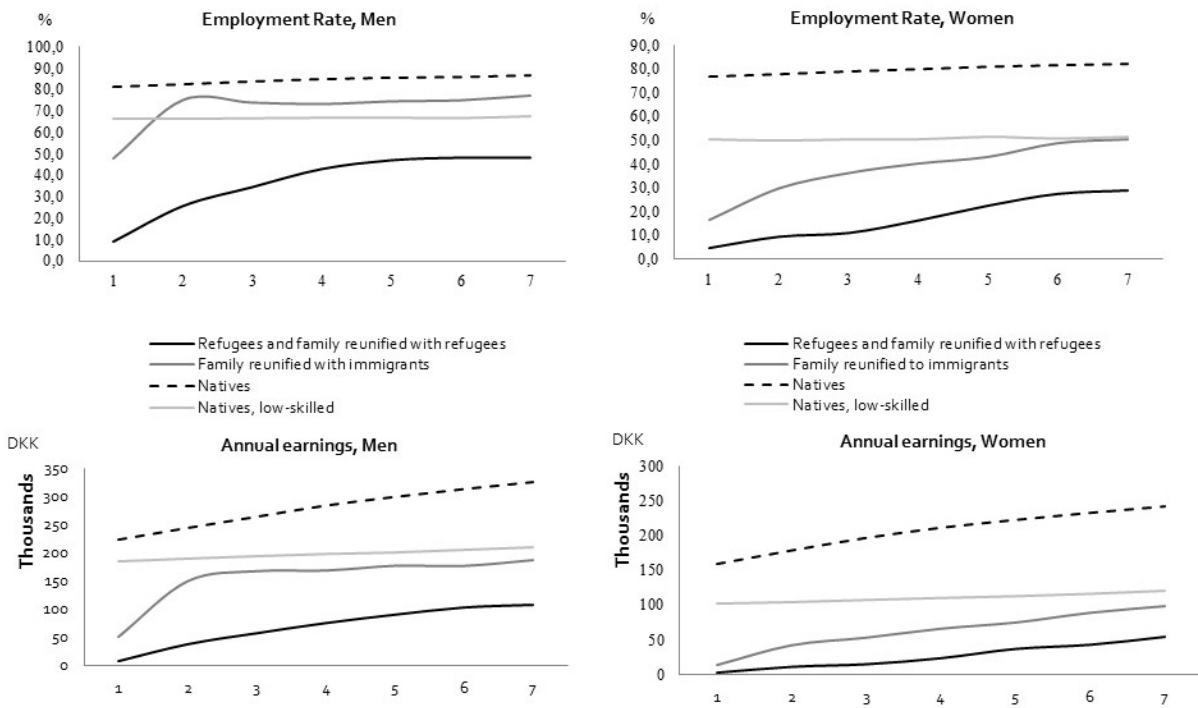

Refugees and family reunified with refugees

Family reunified with immigrants

- - Natives

Natives, low-skilled

Refugees and family reunified with refugee - Family reunified with immigrants

- - Natives

Natives, low-skilled
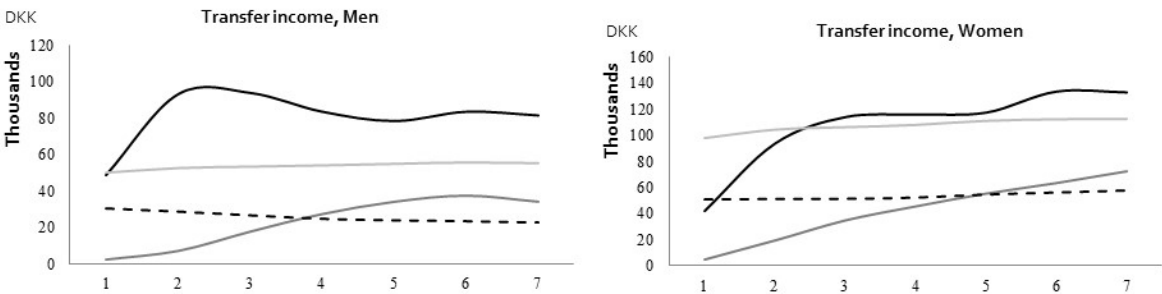

Transferincome, Women

Refugees and family reunified with
- Family reunified with immigrants

- - Natives

Natives, low-skilled

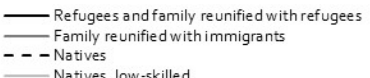

Source: Own calculations based on Statistics Denmark records. 


\title{
3. Labor market integration of refugees in Finland ${ }^{19}$
}

\author{
Matti Sarvimäki2o
}

\begin{abstract}
This paper documents Finland's policy response to the increase in asylum applications in 2015 and the labor market performance of earlier immigrants living in Finland. Immigrants born in Afghanistan, Iraq and Somalia had substantially lower employment rates, earned less and received more social benefits than other immigrant groups or natives in 1990-2013. The immigrant-native gaps in employment and earnings decreased over time but remained large. Ten years after arriving in Finland, the average earnings of immigrant men from these countries were only $22-38 \%$ of the average earnings of native men of the same age. The relative earnings of women were even smaller. Furthermore, the difference in equivalence-scaled social benefits persisted over time despite the narrowing of earnings gaps.
\end{abstract}

- Keywords: integration, employment, immigrants, refugees, asylum seekers.

- JEL codes: J61, J31.

19 I thank Anna Piil Damm and the two referees, Knut Røed and Torben Tranæs, for their insightful comments

${ }^{20}$ Aalto University School of Business and VATT Institute for Economic Research, matti.sarvimaki@aalto.fi 


\subsection{Introduction}

Between 2014 and 2015, the number of asylum applications filed in Finland increased by $890 \%$. While the absolute numbers remained at roughly the level of a "normal" year in neighboring Sweden, inflows on this scale had not been seen in Finland since World War II. Like everywhere in Europe, stories of asylum seekers filled the news and captured the public imagination. A major part of the ensuing policy debate concerned the expected labor market performance of those who would stay in Finland and the consequent impact on public finances.

This paper aims to inform the policy debate by documenting how earlier immigrants from refugee-sending countries have coped in the Finnish labor market in 1990-2013. The results are rather bleak. At the end of their first year in Finland, only $4 \%$ of men born in Iraq were employed and their average earnings were only $4 \%$ of the average earnings of native men of the same age. This immigrant-native gap decreased over time, but remained large. Ten years after arrival, the average earnings of men born in Iraq were still less than a quarter of the average earnings of same-age native men. The results for men born in Afghanistan and Somalia are similar, except that they experienced slightly faster earnings growth than Iraqis. The differences in labor market performance between women from these countries and native women were even larger than those for men.

The low earnings of immigrants from refugee-sending countries are partly reflected in their social benefits. Immigrants from Afghanistan, Iraq and Somalia receive roughly twice as much in (equivalence-scaled) benefits as natives. However, despite an increase in earnings over time in Finland, benefits tend to remain quite constant. In fact, earnings and benefits increase at the same time among some immigrant groups. These patterns highlight the complexity of the Finnish benefits system and the importance of examining both labor market performance and benefits when assessing the fiscal effect of immigration.

An unfortunate limitation of my analysis is that Statistics Finland does not currently hold information on the residence permit status of immigrants. While the majority of immigrants from Afghanistan, Iraq and Somalia are likely to be refugees (or familyreunified members of refugees), country of birth is unlikely to be a good approximation for residence status for immigrants from other origin regions. For example, while almost one thousand Russians obtained asylum in Finland between 2000 and 2015, they 
and their families represent only a small fraction of the roughly 80,000 Russian immigrants living in Finland in $2015 .{ }^{21}$

This paper adds to the large literature examining the labor market integration of immigrants (see Borjas 1999 and Kerr and Kerr 2011 for reviews). Sarvimäki (2011) documents the integration of immigrants arriving in the 1990 in the Finnish labor markets. Previous work examining other Nordic countries includes Edin et al. (2000), Barth et al. (2004), Nielsen et al. (2004), and papers in this volume. Salminen (2015) presents a detailed comparison of the social benefits and the use of public services among immigrants living in Finland by country of birth.

The rest of this paper is organized as follows. The next two sections provide a brief history of the pattern of refugees in Finland and an overview of the policy responses to the rapid increase in asylum seekers in 2015 . Section 3.4 presents the data and Sections 3.5 and 3.6 the results. The final section concludes.

\subsection{Refugees in Finland}

Finland has a long, if often forgotten, history as a destination for refugees. ${ }^{22}$ After gaining independence in the midst of the Russian Revolution, Finland became a natural first destination for those fleeing the revolution from northwest Russia. According to official statistics, roughly 20,000 refugees from Russia were living in Finland in 1922. However, this number is likely to be an underestimate due to incomplete registration.

During World War II, the numbers increased dramatically as 430,000 persons ( $11 \%$ of the Finnish population) were internally displaced from areas ceded to the Soviet Union. In addition, 63,000 Ingrian Finns were moved to Finland during the war. These two groups faced very different policies. The displaced population was resettled in the remaining parts of Finland and gained compensation for their lost property (see e.g. Pihkala 1952 for discussion). This resettlement policy is widely considered a success. Waris et al. (1952) argue that the social integration of the displaced population was well

\footnotetext{
${ }^{21}$ The number of asylums is from the Finnish Immigration Service and the number of Russian immigrants is from Statistics Finland. The latter is defined as persons whose "background country" is either Russia or the Soviet Union.

${ }^{22}$ The numbers quoted in this section are from Martikainen et al. (2013), and from the websites of the Finnish Immigration Service and Statistics Finland (visited in September 2016).
} 
underway already in the late 1940s, and Sarvimäki et al. (2016) show that the displaced population fared remarkably well in the post-war labor market.

In contrast, Ingrian Finns were returned to the Soviet Union at the end of the war. This marked a new era in Finland's refugee policy. All kinds of immigration were tightly restricted and virtually no one was granted asylum. A tentative opening was made with the arrival of 180 Chilean refugees in 1973-1978. A more organized refugee policy began in 1979 with the admission of the first Vietnamese refugees. However, numbers remained very limited throughout the 1980 .

The number of individuals seeking international protection from Finland increased in the early 1990s, and Finland granted asylum to about 5,000 individuals between 1990 and 1994. Most of these were fleeing the civil wars in disintegrating Yugoslavia and Somalia. By the end of the 1990 , roughly 18,000 refugees and their family members were living in Finland. In addition, Ingrian Finns and their descendants were granted return migrant status in the early 1990 s and roughly 30,000 Ingrian Finns moved to Finland during the next two decades.

Figure 1: Asylum applications and positive decisions on international protection, 1990-2015

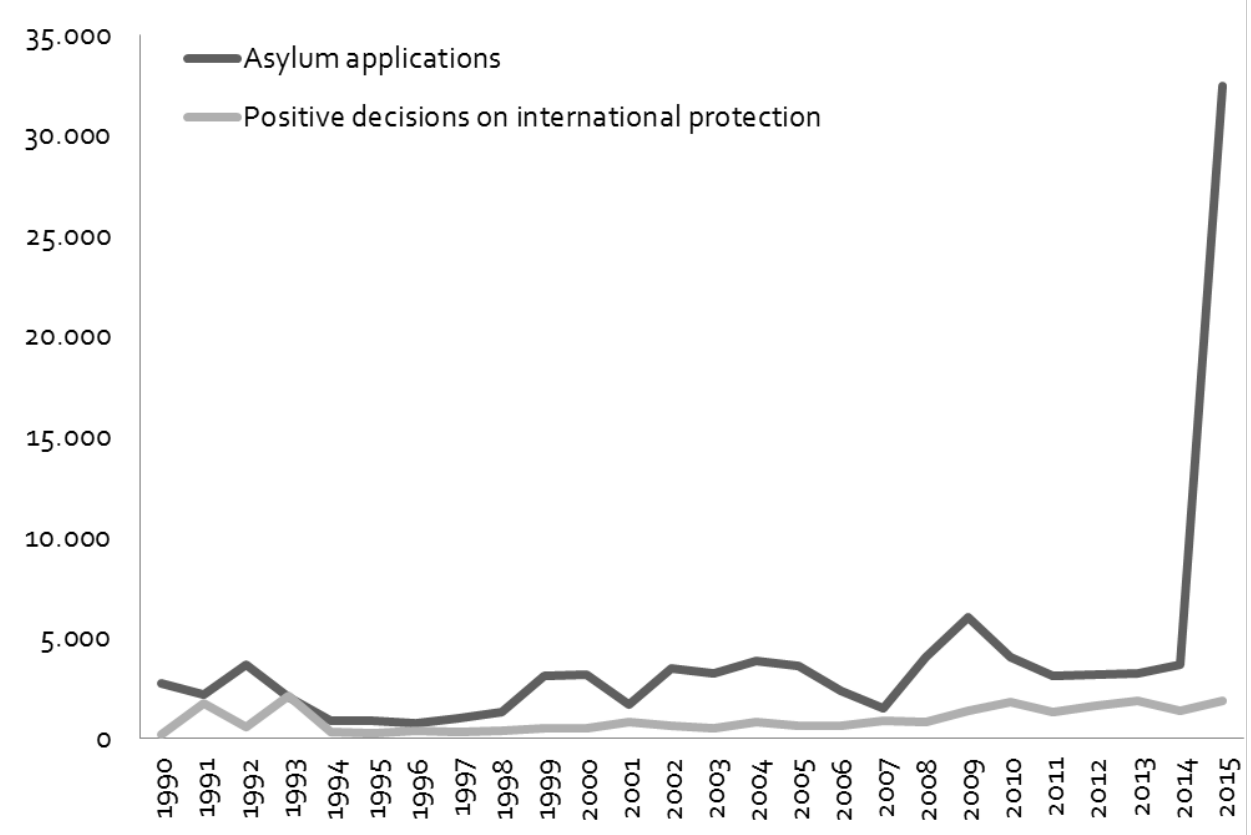


As shown in Figure 1, the number of annual asylum applications ranged between 1,500 and 6,000 and positive decisions between 500 and 1,800 in the period from 1990 to 2014. These inflows represented a relatively small share of overall immigration. During this period, the total immigrant population grew almost ninefold from 37,000 to 320,000 persons (or from 0.8 to $5.9 \%$ of the population).

Figure 2 presents the top 10 source countries of refugees and asylum seekers in 20002014. For each source country, the top bars plot the number of asylum applications and the bottom bars the number of positive decisions (including quota refugees). Three countries - Iraq, Somalia and Afghanistan - correspond to $60 \%$ of positive decisions and $30 \%$ of applications. Citizens of Russia and the former Yugoslavia also filed a relatively large number of applications, but most of these were declined. Furthermore, there were only 804 applications from Syrians, almost all of them made in 2011-2014. 
Figure 2: Asylum applications and positive decisions on international protection, by country, 2000-2014

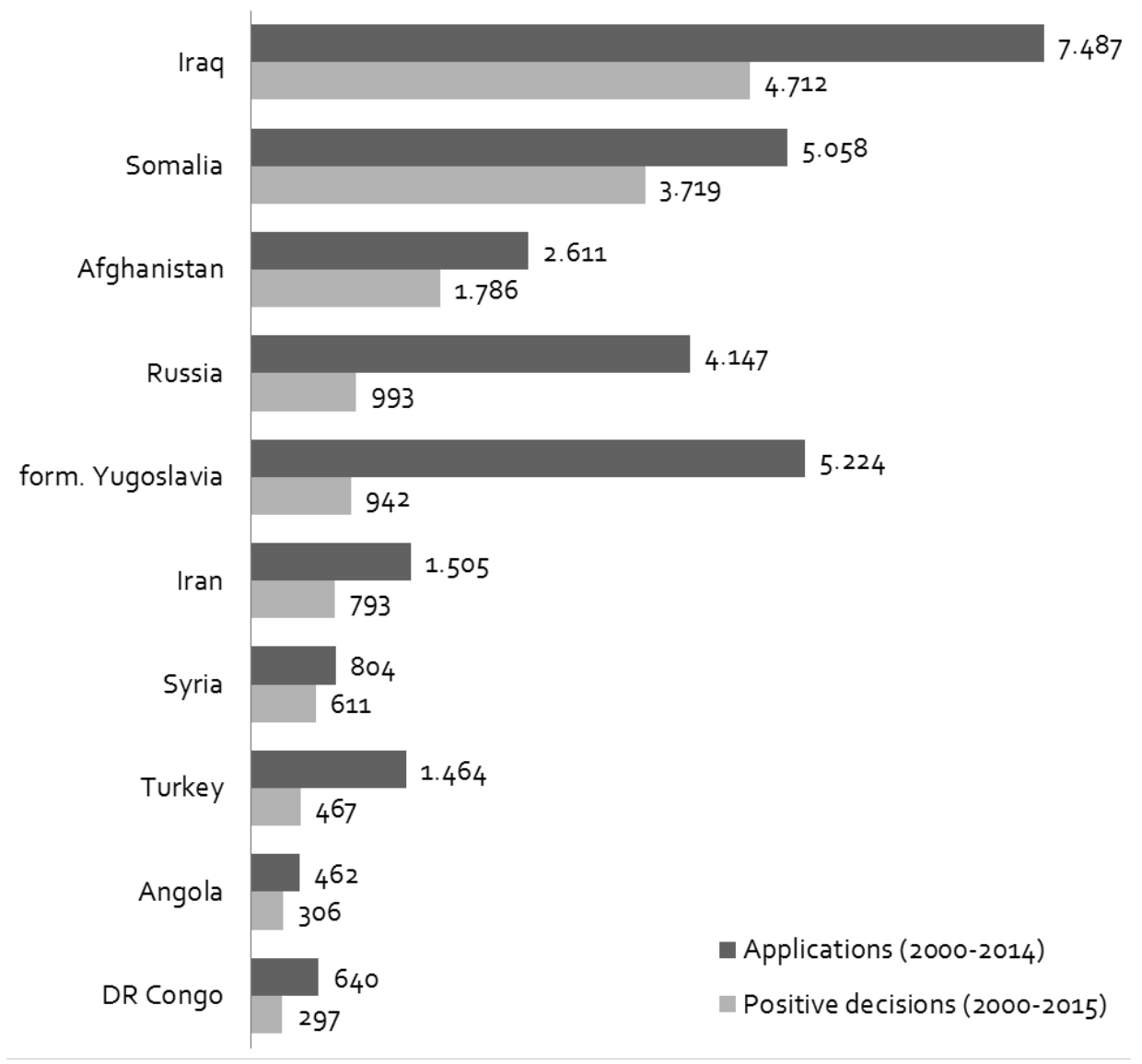

Source: Finnish Immigration Service.

Little of the developments discussed above can be seen from Figure 1, however, because the scale of the vertical axis is so dominated by the last observation in the timeseries for asylum applications. In 2015, Finland received 32,476 applications - a large proportion of which are still being processed by the Immigration Service. In 
comparison, there were 5,988 applications in the previous record year in 2009, and an average of 2,700 applications during the 1990-2014 period.

Figure 3: Asylum applications by country, 2015

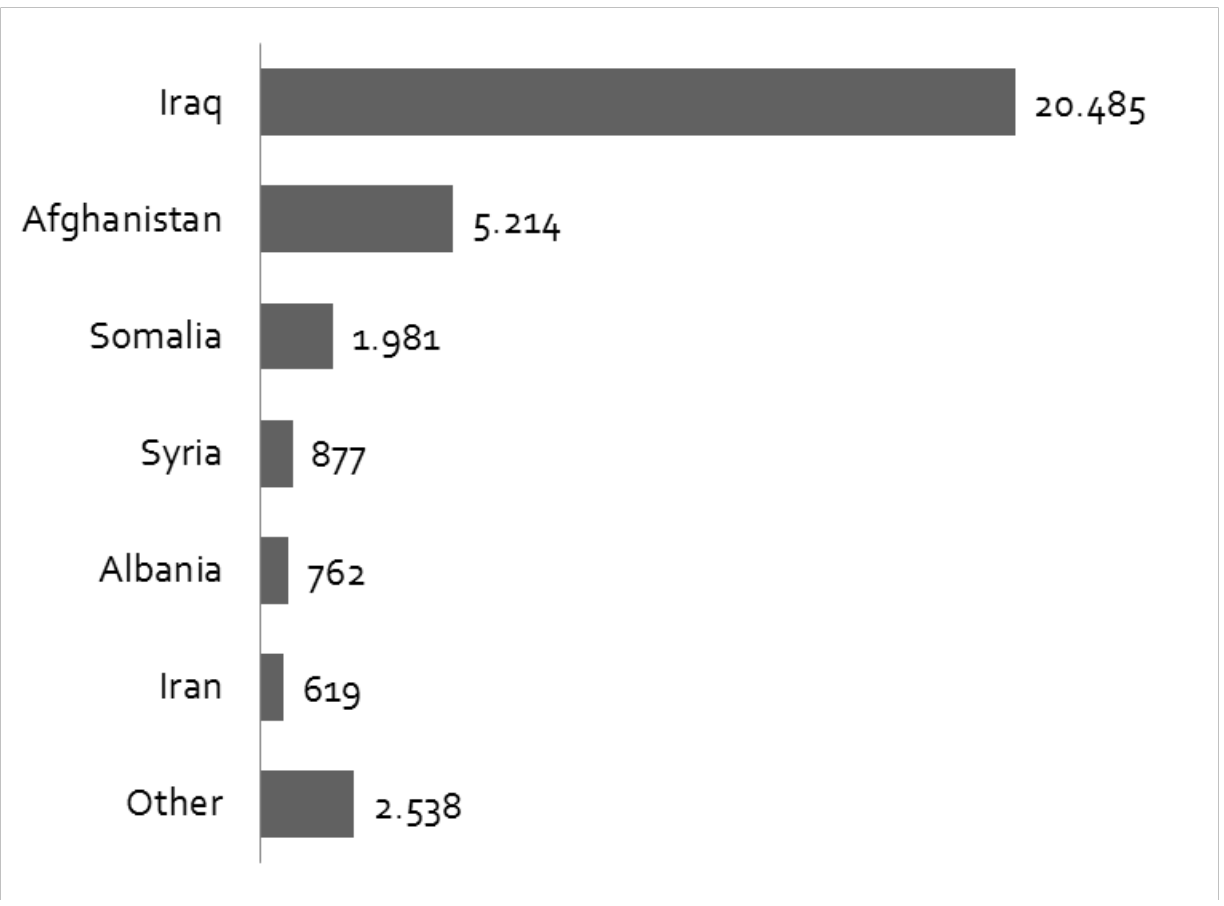

Source: Finnish Immigration Service.

Figure 3 presents 2015 asylum applications by origin country. The top three countries are the same as in figure 2, but almost two thirds of the applications were filed by Iraqis. While there are more applications from Syrians than during the previous 15 years combined, they correspond to less than $3 \%$ of all applicants.

\subsection{Policy responses to the 2015 increase in asylum seekers}

The Finnish government responded to the rapid increase in asylum seekers in three ways. First, it had to cope with the situation at hand. Between August and December 2015, the number of reception centers increased from 22 to 144 and the number of workers at the 
Immigration Service from 365 to $508 .{ }^{23}$ Furthermore, the asylum application process was accelerated by increasing automation and reducing the duration of asylum interviews.

The second response was to make Finland a less attractive destination. For instance, the Immigration Service published a press release on May 16, 2016 entitled "Humanitarian protection no longer granted; new guidelines issued for Afghanistan, Iraq and Somalia". The content was arguably less dramatic than the title. Humanitarian protection referred to one type of residence permit that had now been repealed, while asylum seekers could still gain residence through the asylum procedure or on the basis of subsidiary protection. ${ }^{24}$ Nevertheless, removing this residence permit category clearly tightened asylum policy. Furthermore, the press release stated that the security situation had improved in Afghanistan, Iraq and Somalia and that the Immigration Service had updated its country guidelines accordingly.

Other forms of reducing "pull factors" included restrictions in family reunification and reductions in social benefits. According to the new rules, recently admitted refugees can apply for family reunification only if they have sufficient income. For instance, a person wishing to bring a spouse and two children to Finland would need to have a net market income of at least EUR 2,600 per month. However, this income requirement does not apply to families formed before the refugee arrived in Finland, if the refugee applies for family reunification within three months of obtaining asylum. ${ }^{25}$

The third policy response was to rethink integration policies. The government published an action plan on May 2016 on the overhaul of integration services. ${ }^{26}$ The plan included measures to streamline the inception of integration services; to improve recognition of education obtained abroad; to integrate language studies into other studies and so forth. In addition, a new type of public-private initiative was launched. This program combines short language training with a quick pathway to employment and further on-the-job language training. Another novelty of the new program is that it is funded by private capital and investors are compensated based on the unemployment benefits received and taxes paid by the participants (in comparison to

\footnotetext{
${ }^{23}$ The figures are from the 2015 annual report of the Finnish Immigation Service.

24 Before May 16, 2016, residence permits could be granted on the basis of humanitarian protection when the applicant did not meet the requirements for asylum, but could not return to her home country because of a poor security situation or an environmental disaster.

25 Those who have been granted international protection on other grounds always have to fulfill the income requirement.

${ }^{26}$ See dlvr.it/LCph5k for a press release on the action plan and https://t.co/ZaOySX8xGG for a press release on the SIB-

based integration programs.
} 
a control group participating in other types of integration programs). More precisely, the impact evaluation is conducted as an RCT, where the Ministry of Employment and Economy invites randomly selected refugees to participate in the new program.

\subsection{Data}

Statistics Finland created my data by combining information from several administrative registers. These data contain annual information on country of birth, mother tongue, nationality, family structure, employment and income for the entire working age population living in Finland in 1988-2013. I focus on 25-60 year old individuals who immigrated at age 18 or older. ${ }^{27}$

A limitation of these data is that they contain no information on the type of residence permit. Thus I have to approximate refugee status based on the country of birth. This approximation is clearly problematic for origin areas such as the former Soviet Union and Turkey. While some immigrants from these countries moved to Finland due to a need for international protection, most came for other reasons. On the other hand, the vast majority of those coming from Afghanistan, Iraq and Somalia are likely to have entered Finland for international protection or as family members of those granted asylum. Furthermore, Finland had no history of labor migration from the former Yugoslavia - or from virtually anywhere prior to the early 1990s. Thus the share of refugees among those born in the former Yugoslavia is likely to be higher in Finland than in the other Nordic countries.

Table 1 reports basic background characteristics for eight groups of immigrants and natives. In comparison to natives, immigrants from most origin areas tend to be younger, more often male, more often married and to have more children. The differences are particularly pronounced among those coming from Afghanistan, Iraq and Somalia, whereas immigrants from the former Soviet Union and the OECD area are more similar to natives along these dimensions.

\footnotetext{
${ }^{27}$ For computational reasons, the results reported in Tables $2-5$ and A1 use data containing the full population of immigrants and a $10 \%$ random sample of natives.
} 
Table 1: Descriptive statistics

\begin{tabular}{|c|c|c|c|c|c|c|c|c|c|}
\hline & \multicolumn{8}{|c|}{ Region of origin } & \multirow[b]{2}{*}{ Natives } \\
\hline & Iraq & $\begin{array}{l}\text { Afgha } \\
\text { nistan }\end{array}$ & Somalia & $\begin{array}{l}\text { Former } \\
\text { Yugos } \\
\text { lavia }\end{array}$ & $\begin{array}{l}\text { Former } \\
\text { Soviet } \\
\text { Union }\end{array}$ & Turkey & OECD & Other & \\
\hline Age & 37.8 & 38.3 & 37.1 & 38.6 & 40.9 & 35.6 & 36.9 & 37.2 & 42.7 \\
\hline Age at arrival & 31.3 & 33.5 & 29.0 & 30.9 & 33.9 & 28.4 & 31.6 & 31.5 & - \\
\hline Female & 0.38 & 0.49 & 0.46 & 0.43 & 0.65 & 0.20 & 0.33 & 0.49 & 0.49 \\
\hline $\begin{array}{l}\text { Number of } \\
\text { children }\end{array}$ & 2.1 & 1.9 & $3 \cdot 4$ & 1.8 & 0.9 & 1.4 & 1.0 & 1.1 & 1.0 \\
\hline \multicolumn{10}{|l|}{ Marital status } \\
\hline Single & 0.20 & 0.14 & 0.13 & 0.12 & 0.11 & 0.12 & 0.41 & 0.27 & 0.31 \\
\hline Married & 0.69 & 0.74 & 0.67 & 0.78 & 0.70 & 0.69 & 0.50 & 0.59 & 0.55 \\
\hline Divorced & 0.10 & 0.06 & 0.17 & 0.08 & 0.17 & 0.18 & 0.09 & 0.14 & 0.12 \\
\hline Widow & 0.01 & 0.07 & 0.03 & 0.02 & 0.02 & 0.00 & 0.00 & 0.01 & 0.02 \\
\hline \multicolumn{10}{|l|}{ Year of arrival } \\
\hline 1990-1994 & 0.13 & 0.01 & 0.31 & 0.28 & 0.23 & 0.19 & 0.15 & 0.14 & . \\
\hline 1995-1999 & 0.24 & 0.05 & 0.15 & 0.23 & 0.19 & 0.15 & 0.19 & 0.11 & . \\
\hline 2000-2004 & 0.19 & 0.48 & 0.11 & 0.23 & 0.23 & 0.22 & 0.24 & 0.20 & . \\
\hline $2005-2009$ & 0.44 & 0.47 & 0.43 & 0.25 & 0.35 & 0.44 & 0.42 & 0.54 & . \\
\hline $\begin{array}{l}\text { Years to first } \\
\text { job }\end{array}$ & 4.5 & 4.2 & 5.6 & 4.1 & 3.0 & 2.3 & 1.0 & 2.0 & . \\
\hline $\begin{array}{l}\text { Emigrates } \\
\text { during the first } \\
10 \text { years }\end{array}$ & 0.10 & 0.07 & 0.19 & 0.12 & 0.16 & 0.08 & 0.22 & 0.11 & \\
\hline Observations & 44,146 & 12,350 & 51,211 & 64,359 & 453,710 & 44,532 & 208,507 & 641,116 & $58,888,641$ \\
\hline Individuals & 5,184 & 1,863 & 5,027 & 5,661 & 45,797 & 4,698 & 32,635 & 100,038 & $3,920,391$ \\
\hline
\end{tabular}

Note: Averages from population level data on 25-60 year old immigrants who immigrated at age 18 or older and natives in years 1990-2013

Source: See section 3.4. 


\subsection{Employment}

The top panels of Figure 4 present employment rates for the eight immigrant groups and natives in 1990-2013. Employment is defined either as holding a job at the end of the year (panel A) or having any wage, salary or entrepreneurial income (panel B). The latter definition yields higher employment rates, but the patterns across immigrant groups and over time are very similar for both measures. Thus for the rest of this paper I focus on employment at the end of the year.

Figure 4 shows a large variation in employment rates across immigrant groups. While immigrants had a lower employment rate than natives throughout the 19902013 period, the immigrant-native gap decreased substantially over time. Another notable pattern is that in the 1990s there were large differences in the employment rates of immigrants from the OECD countries, the former Soviet Union, former Yugoslavia, Turkey and the group "others". By 2013, however, these differences had largely disappeared and the employment rates of all these groups had stabilized at 52$58 \%$. In contrast, the employment rates of immigrants from Iraq, Afghanistan and Somalia moved roughly together and remained modest at 20-26\% in 2013.

A limitation of time-series such as those reported in Figure 4 is that they mix together employment dynamics attributable to the integration process and changes in the composition of the immigrant population. The first part of the composition effect is due to the fact that it typically takes immigrants some time to find employment after arriving in the host country. Thus employment rates may differ between immigrant groups simply because one group has a larger share of recent arrivals.

Figure 5 illustrates the issue by separately plotting the employment rates for four arrival cohorts. It shows that, within each origin region, those who arrived earlier tend to work more than those who arrived more recently. The employment of each arrival cohort also increased faster than the employment of the entire immigrant population from the same origin region. Furthermore, Figure 5 illustrates heterogeneity between immigrants from the same origin areas arriving in different years. For example, immigrants from Iraq and Somalia arriving in the early 2000 s have had a higher employment rate from 2008 onwards than their compatriots who arrived in the late 1990 . 
Figure 4: Employment rates, average earnings and average equivalence-scaled benefits by country of origin, 1990-2013
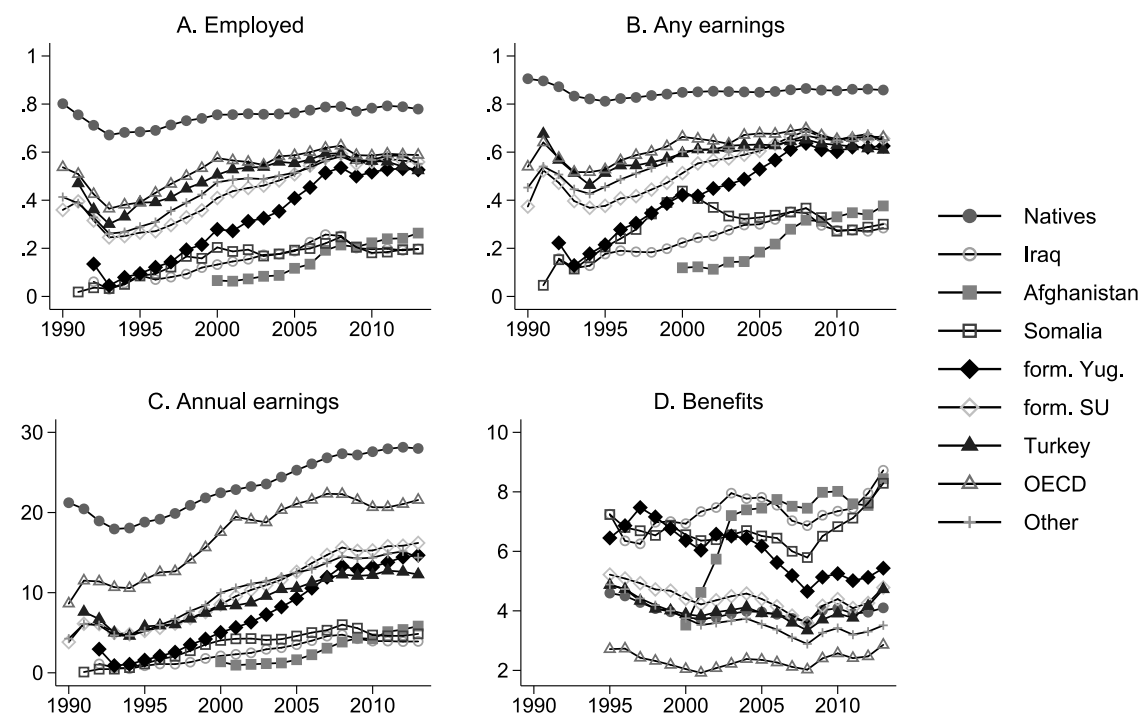

Note: This figure presents time-series for (a) employment rate at the end of the year, (b) share of individuals who have any earnings during a year, (c) average annual earnings (including zeros), and (d) average equivalence-scaled income transfers for $25-60$ year old individuals who immigrated at age 18 or older. Earnings and benefits converted to 2010 euros using Statistics Finland's consumer price index.

Source: See section 3.4 .

The second key component of the composition effect is that as immigrants spend more time in the host country, they also grow older. Thus the patterns presented in Figure 5 mix together improvements in employment due to accumulating country-specific experience and improvements due to accumulating experience more generally. A large literature has attempted to isolate these two sources of improved labor market performance from each other by comparing the employment and earnings dynamics of immigrants to those of observationally identical natives (see e.g. Borjas, 1999, and Kerr and Kerr, 2011, for reviews). 
Figure 5: Employment rate by country of origin and arrival cohort

A. Iraq

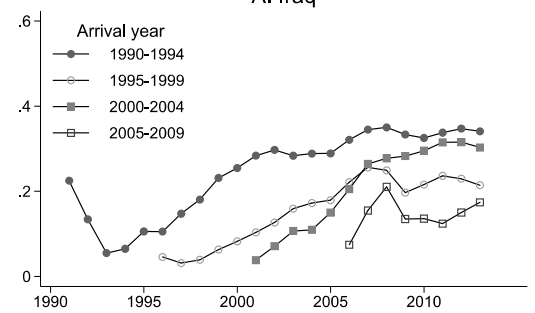

C. Somalia

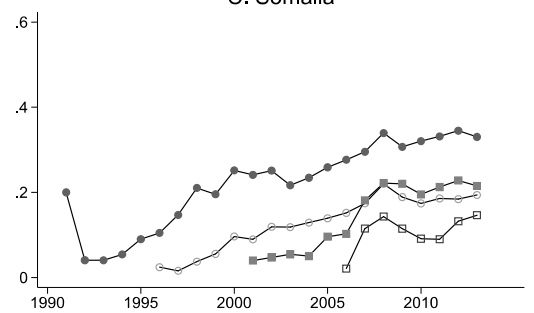

E. form. Soviet Union

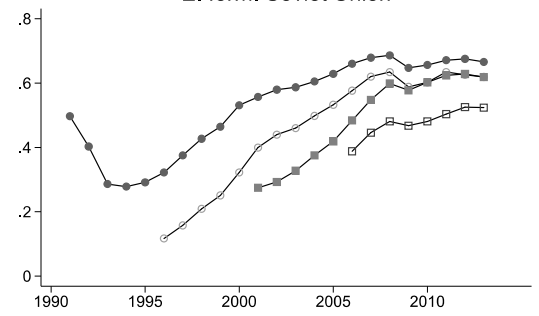

G. OECD

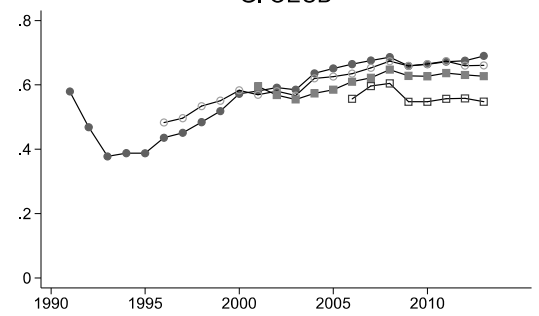

B. Afghanistan

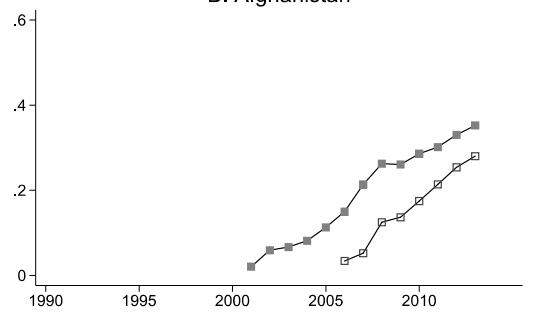

D. form. Yugoslavia

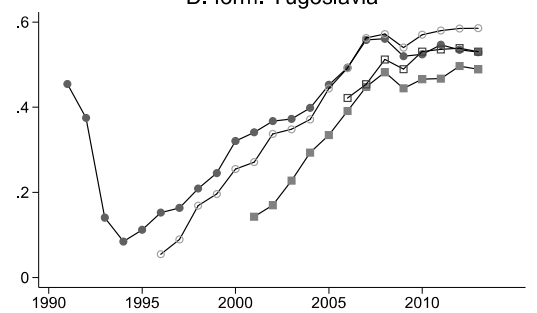

F. Turkey

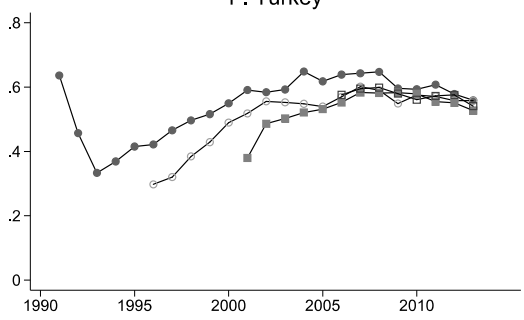

H. Other

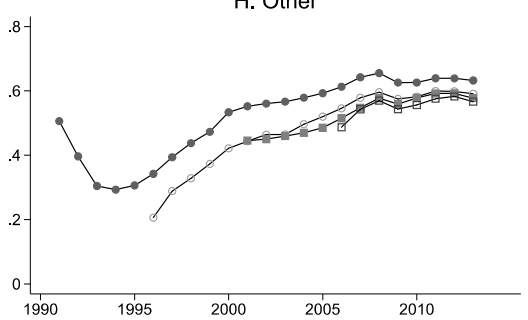

Note: This figure presents time-series for employment rate at the end of the year by region of origin in 1990-2013 for 25-60 year old individuals who immigrated at age 18 or older.

Source: See section $3 \cdot 4$. 
Table 2: Differences in employment rates over time lived in Finland

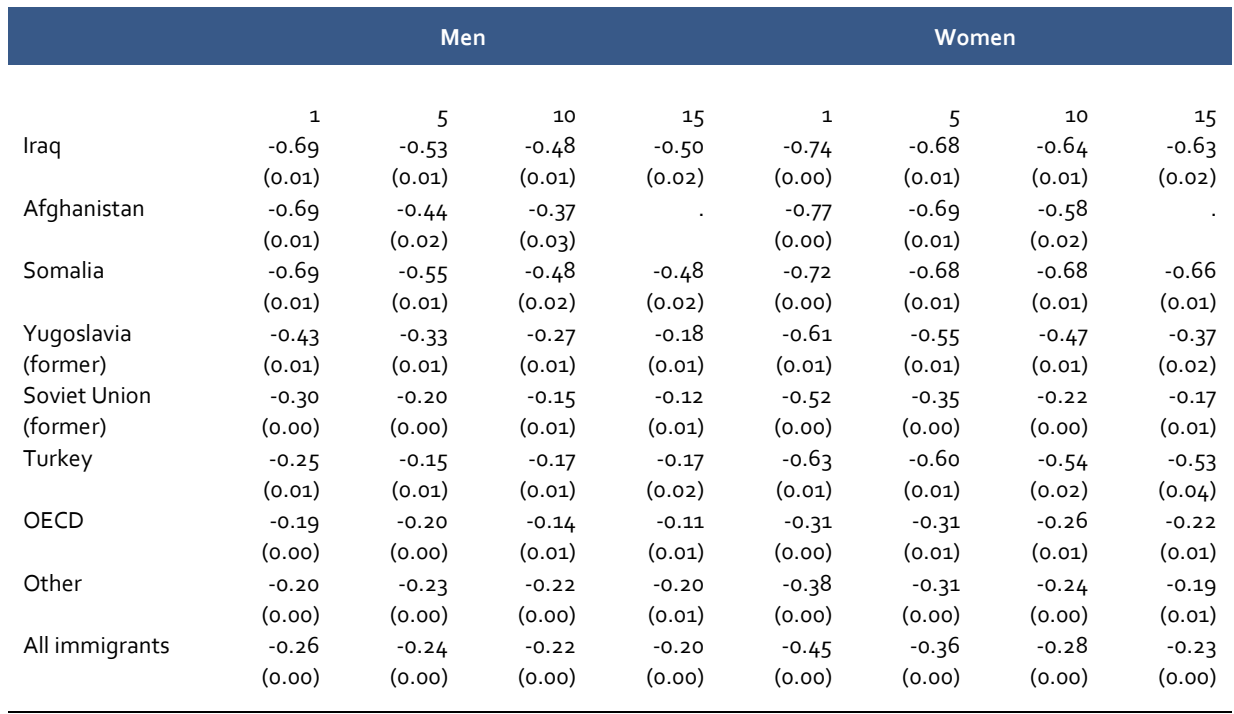

Note: This table reports immigrant-native employment gaps after conditioning on gender, age, calendar year and time lived in Finland. The estimates are constructed as

$y y s m g=\Sigma \theta g(y s m, t, \mathbf{X})[e g(y s m, t, \mathbf{X})-e n(t, \mathbf{X})]$, is the employment rate of immigrants from source area $g$ at the end of year $t$ who have background characteristics $X$ (age and gender) and have lived in Finland for $y$ sm years; $e^{\wedge} n(t, X)$ is the employment rate of natives with the same background characteristics $X$ in the same year $t$, and the weights $\theta^{\wedge} g(y s m, t, X)=N^{\wedge} g(y s m, t, X) / N^{\wedge} g(y s m)$ are the share of immigrants from source area $g$ in year $t$ with characteristics $X$ out of all immigrants from this source area observed in their ysmth year in Finland. Bootstrapped standard errors (in parentheses) are calculated using 100 replications using data for a random sample of $10 \%$ of natives and the full population of immigrants.

Source: See section 3.4.

Table 2 reports employment rate gaps between immigrants and natives over time lived in Finland. I constructed these estimates by comparing the employment rates of immigrants to the employment rate of natives of the same age and gender during the same calendar year (see the note to table 2 for details). The first entry, at the top-left, shows that during their first full calendar year in Finland, men from Iraq had a 70 percentage point lower employment rate than native men of the same age. Over time, their employment grew faster than that of natives, but even after ten years in Finland, the employment gap was 48 percentage points. The corresponding figures for men 
from Somalia were almost identical at 68 percentage points in the first year and 48 percentage points ten years after arrival, respectively. Afghani men started with a similarly large initial gap, but experienced somewhat faster employment growth. Nevertheless, at the end of their tenth year in Finland, their employment rate was 37 percentage points lower than that of same-age native men.

The remainder of Table 2 reports similar measures for the other immigrant groups. There are three notable patterns. Men from OECD countries had the highest relative employment rates, but even for them the employment gap remained at 14 percentage points a decade after moving to Finland. The relative employment rates of women were lower than those of men for all groups. Finally, immigrants' employment rates tended to approach the employment rates of natives during the first ten years in Finland, but the gaps remained roughly constant after that.

The third potential source of composition effects is due to selective outmigration (see Dustmann and Görlach, 2015, for discussion). During their first ten years in Finland, $15 \%$ of immigrants leave Finland (see Table 1 ). If those with particularly low employment prospects were more likely to emigrate than those with better chances of finding employment, the immigrant-native gap would decrease simply due to changes in the average characteristics of the remaining immigrant population. Conversely, if those with the highest employment rates were more likely to leave, the composition changes would mask part of the labor market integration among those staying. Appendix Table 1 examines this issue by reproducing table 2 using data only for those who stay in Finland for at least 10 years. While the immigrant-native gaps tend to be slightly narrower for immigrants who stayed longer, these differences are small and do not affect any of my conclusions. Thus I include all immigrants in the rest of the analysis regardless of whether they end up staying or leaving Finland.

\subsection{Earnings}

I next repeat the analysis above, but now using annual earnings as an outcome variable. This provides a more comprehensive view of labor market integration than employment rates, because annual earnings capture both wages and the hours worked during a year. I measure earnings as the sum of total wages, salary and entrepreneurial income and include individuals with zero earnings in the analysis. All monetary measures are converted to 2010 euros using Statistics Finland's consumer price index. 
Panel C of Figure 4 presents a largely similar picture as panels A and B. All immigrant groups have lower average earnings than natives and those from Afghanistan, Iraq and Somalia fare particularly badly. However, in contrast to the employment rates, immigrants from OECD countries have substantially higher average earnings than other immigrant groups. That is, immigrants from OECD countries either work more hours or have higher wages (or both).

Figure 6 and Table 3 document earnings growth over time lived in Finland. Again, the results closely mirror those for employment. During their first full calendar year in Finland, Iraqi men earned only $4 \%$ of what comparable natives did. Over time, their earnings grew faster than the earnings of natives, but even after ten years in Finland, the average earnings of Iraqi men were less than a quarter of the average earnings of native men of the same age. The relative earnings of immigrants from Afghanistan and Somalia grew somewhat faster. Ten years after arrival the average earnings of Afghani men were $38 \%$ and the average earnings of Somali men $28 \%$ of the earnings of sameage native men.

Other patterns are also qualitatively similar to those for employment. As noted above, the most important difference is that the earnings of men from OECD countries substantially differed from the earnings of other non-refugee immigrant groups despite these groups having had roughly similar employment rates. Again, the relative earnings of women were lower than those of men for all groups and immigrants' earnings approached the earnings of natives during the first decade after arrival. However, the gaps remained large even after living in Finland for more than a decade. 
Figure 6: Average annual earnings by country of origin and arrival cohort

A. Iraq

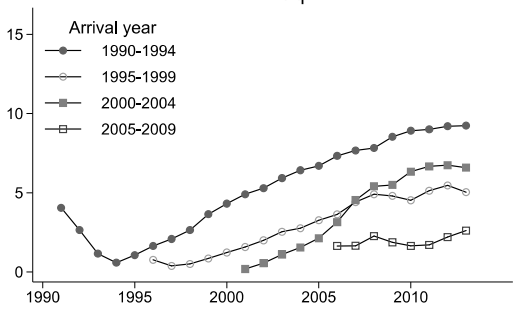

C. Somalia

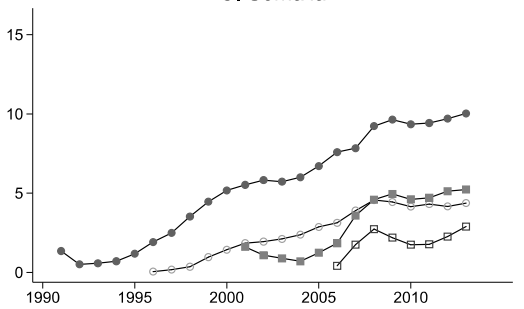

E. form. Soviet Union

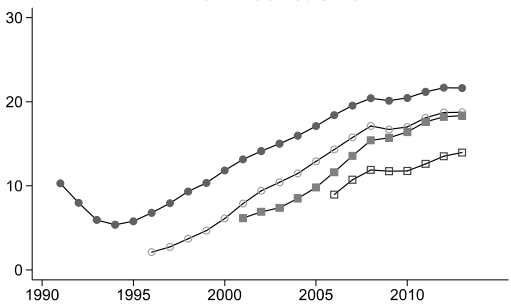

G. OECD

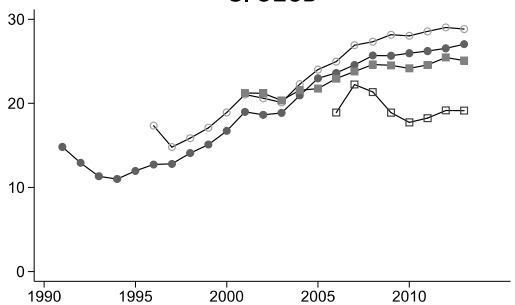

B. Afghanistan

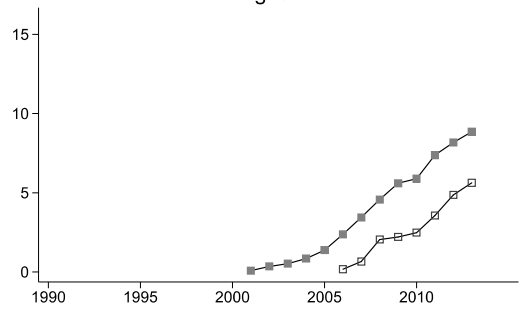

D. form. Yugoslavia

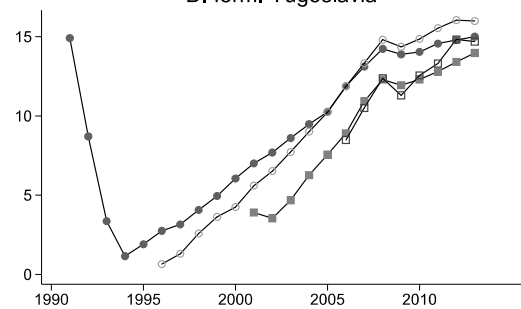

F. Turkey

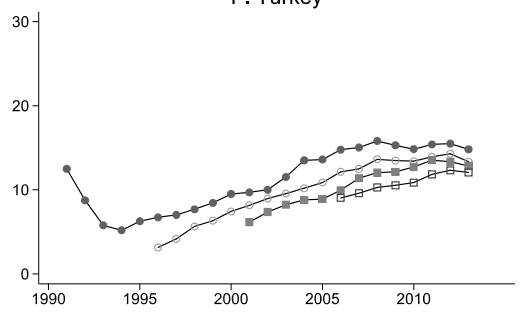

H. Other

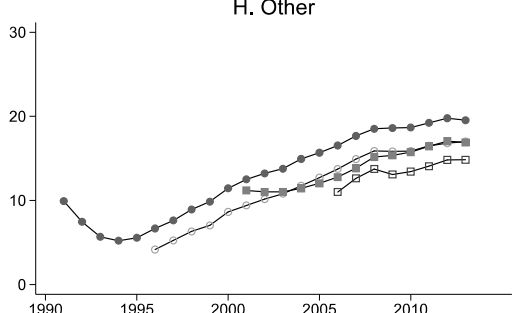

Note: This figure presents time-series for average annual earnings by region of origin in 1990-2013 for 25-60 year old individuals who immigrated at age 18 or older.

Source: See section 3.4 . 
Table 3: Relative annual earnings over time lived in Finland

\begin{tabular}{|c|c|c|c|c|c|c|c|c|}
\hline & \multicolumn{4}{|c|}{ Men } & \multicolumn{4}{|c|}{ Women } \\
\hline & 1 & 5 & 10 & 15 & 1 & 5 & 10 & 15 \\
\hline Iraq & $\begin{array}{r}0.04 \\
(0.00)\end{array}$ & $\begin{array}{r}0.15 \\
(0.01)\end{array}$ & $\begin{array}{r}0.22 \\
(0.01)\end{array}$ & $\begin{array}{r}0.21 \\
(0.02)\end{array}$ & $\begin{array}{r}0.01 \\
(0.00)\end{array}$ & $\begin{array}{r}0.07 \\
(0.01)\end{array}$ & $\begin{array}{r}0.13 \\
(0.01)\end{array}$ & $\begin{array}{r}0.15 \\
(0.02)\end{array}$ \\
\hline Afghanistan & $\begin{array}{r}0.04 \\
(0.01)\end{array}$ & $\begin{array}{r}0.25 \\
(0.02)\end{array}$ & $\begin{array}{r}0.3^{8} \\
(0.04)\end{array}$ & . & $\begin{array}{r}0.01 \\
(0.00)\end{array}$ & $\begin{array}{r}0.06 \\
(0.01)\end{array}$ & $\begin{array}{r}0.23 \\
(0.03)\end{array}$ & . \\
\hline Somalia & $\begin{array}{r}0.04 \\
(0.00)\end{array}$ & $\begin{array}{r}0.17 \\
(0.01)\end{array}$ & $\begin{array}{r}0.29 \\
(0.01)\end{array}$ & $\begin{array}{r}0.31 \\
(0.02)\end{array}$ & $\begin{array}{r}0.01 \\
(0.00)\end{array}$ & $\begin{array}{r}0.06 \\
(0.01)\end{array}$ & $\begin{array}{r}0.09 \\
(0.01)\end{array}$ & $\begin{array}{r}0.12 \\
(0.01)\end{array}$ \\
\hline $\begin{array}{l}\text { Yugoslavia } \\
\text { (former) }\end{array}$ & $\begin{array}{r}0.26 \\
(0.01)\end{array}$ & $\begin{array}{r}0.43 \\
(0.01)\end{array}$ & $\begin{array}{r}0.48 \\
(0.01)\end{array}$ & $\begin{array}{r}0.51 \\
(0.02)\end{array}$ & $\begin{array}{r}0.10 \\
(0.01)\end{array}$ & $\begin{array}{r}0.18 \\
(0.01)\end{array}$ & $\begin{array}{r}0.29 \\
(0.01)\end{array}$ & $\begin{array}{r}0.39 \\
(0.02)\end{array}$ \\
\hline $\begin{array}{l}\text { Soviet Union } \\
\text { (former) }\end{array}$ & $\begin{array}{r}0.45 \\
(0.01)\end{array}$ & $\begin{array}{r}0.60 \\
(0.01)\end{array}$ & $\begin{array}{r}0.69 \\
(0.01)\end{array}$ & $\begin{array}{r}0.70 \\
(0.01)\end{array}$ & $\begin{array}{r}0.21 \\
(0.00)\end{array}$ & $\begin{array}{r}0.40 \\
(0.00)\end{array}$ & $\begin{array}{r}0.57 \\
(0.01)\end{array}$ & $\begin{array}{r}0.67 \\
(0.01)\end{array}$ \\
\hline Turkey & $\begin{array}{r}0.34 \\
(0.01)\end{array}$ & $\begin{array}{r}0.48 \\
(0.01)\end{array}$ & $\begin{array}{r}0.44 \\
(0.02)\end{array}$ & $\begin{array}{r}0.46 \\
(0.03)\end{array}$ & $\begin{array}{r}0.11 \\
(0.01)\end{array}$ & $\begin{array}{r}0.14 \\
(0.02)\end{array}$ & $\begin{array}{r}0.22 \\
(0.02)\end{array}$ & $\begin{array}{r}0.25 \\
(0.05)\end{array}$ \\
\hline OECD & $\begin{array}{r}0.81 \\
(0.01)\end{array}$ & $\begin{array}{r}0.78 \\
(0.01)\end{array}$ & $\begin{array}{r}0.87 \\
(0.01)\end{array}$ & $\begin{array}{r}0.88 \\
(0.02)\end{array}$ & $\begin{array}{r}0.58 \\
(0.01)\end{array}$ & $\begin{array}{r}0.57 \\
(0.01)\end{array}$ & $\begin{array}{r}0.63 \\
(0.02)\end{array}$ & $\begin{array}{r}0.70 \\
(0.03)\end{array}$ \\
\hline Other & $\begin{array}{r}0.52 \\
(0.00)\end{array}$ & $\begin{array}{r}0.55 \\
(0.00)\end{array}$ & $\begin{array}{r}0.56 \\
(0.01)\end{array}$ & $\begin{array}{r}0.57 \\
(0.01)\end{array}$ & $\begin{array}{r}0.37 \\
(0.00)\end{array}$ & $\begin{array}{r}0.47 \\
(0.00)\end{array}$ & $\begin{array}{r}0.55 \\
(0.01)\end{array}$ & $\begin{array}{r}0.60 \\
(0.01)\end{array}$ \\
\hline All immigrants & $\begin{array}{r}0.52 \\
(0.00)\end{array}$ & $\begin{array}{r}0.57 \\
(0.00)\end{array}$ & $\begin{array}{r}0.60 \\
(0.00)\end{array}$ & $\begin{array}{r}0.60 \\
(0.01)\end{array}$ & $\begin{array}{r}0.31 \\
(0.00)\end{array}$ & $\begin{array}{r}0.41 \\
(0.00)\end{array}$ & $\begin{array}{r}0.52 \\
(0.00)\end{array}$ & $\begin{array}{r}0.59 \\
(0.01)\end{array}$ \\
\hline
\end{tabular}

Note: This table reports average relative earnings of immigrants in comparison to natives of the same age and gender. The estimates are constructed as $y_{y s m}^{g}=\sum \theta^{g}(y s m, t, \mathbf{X})\left[w^{g}(y s m, t, \mathbf{X}) / w^{n}(t, \mathbf{X})\right]$, where $w^{g}(y s m, t, \mathbf{X})$ is the average earnings of immigrants from source area $g$ in year $t$ who have background characteristics $\mathbf{X}$ (age and gender) and have lived in Finland for ysm years; $w^{n}(t, \mathbf{X})$ is the average earnings of natives with the same background characteristics $\mathbf{X}$ in the same year $t$, and the weights $\theta^{g}(y s m, t, \mathbf{X})=N^{g}(y s m, t, \mathbf{X}) / N^{g}(y s m)$ are the share of immigrants from source area $g$ in year $t$ with characteristics $x$ out of all immigrants from this source area observed in their $y s m^{\text {th }}$ year in Finland. Bootstrapped standard errors (in parentheses) are calculated using 100 replications using data for a random sample of $10 \%$ of natives and the full population of immigrants.

Source: See section 3.4 .

\subsection{Benefits}

I now turn to documenting differences in the use of social benefits. I measure benefits as the equivalence-scaled sum of all income transfers received by the immigrant and her family members during a calendar year. ${ }^{28}$ I take this measurement approach

\footnotetext{
${ }^{28}$ I use an equivalence scale which assigns a value of 1 to the first household member, 0.7 to other household members aged 15 or older, and 0.5 to each child under 15 . I divide the sum of all benefits paid to household members in a given year with this scale and assign each member the same equivalence-scaled benefits.
} 
because two important benefits - housing allowance and social assistance - are targeted at households rather than individuals. In comparison to the measurement of earnings, another difference is that the data include information on benefits only for the years 1995-2013. Thus it is important to bear in mind that the results are not directly comparable to those reported in the previous section.

Panel D, Figure 4, reports time-series for average annual benefits for the eight immigrant groups and for natives. Average benefits were highest for immigrants from Afghanistan and Iraq, and lowest for immigrants from the OECD countries. These patterns are, of course, exactly what one would expect given the differences in average earnings. However, the better labor market performance of natives was not fully reflected in their benefits. That is, native households collected more benefits, on average, than immigrants from the OECD countries and immigrants from "other" countries despite their higher average earnings. The most likely reason is that the natives are older and more often entitled to benefits determined by earlier earnings.

Figure 7 reports average benefits by arrival cohorts. The patterns for those arriving from the former Yugoslavia and Soviet Union in the 1990 s mirror those for their earnings (see Figure 6). That is, their average earnings increased and benefits decreased over time. However, the average benefits received by other arrival cohorts or immigrants from other countries remained stable or even increased despite the increases in their average earnings.

Table 4 shows that immigrants' average benefits were rather stable over time lived in Finland, also in comparison to the average benefits of natives of the same age. The average equivalence-scaled benefits of households from Iraq, Afghanistan and Somalia remained at about twice the level of the benefits of natives. The relative average benefits of households of men from OECD countries increased during the first five years in Finland and remained constant at about three quarters of the level of native households thereafter. Only immigrants from the former Soviet Union experienced a steady decrease in their relative benefits over time in Finland. However, even for them, the increase in relative earnings was much steeper than the decrease in relative benefits. 
Figure 7: Average equivalence-scaled annual benefits by country of origin and arrival cohort
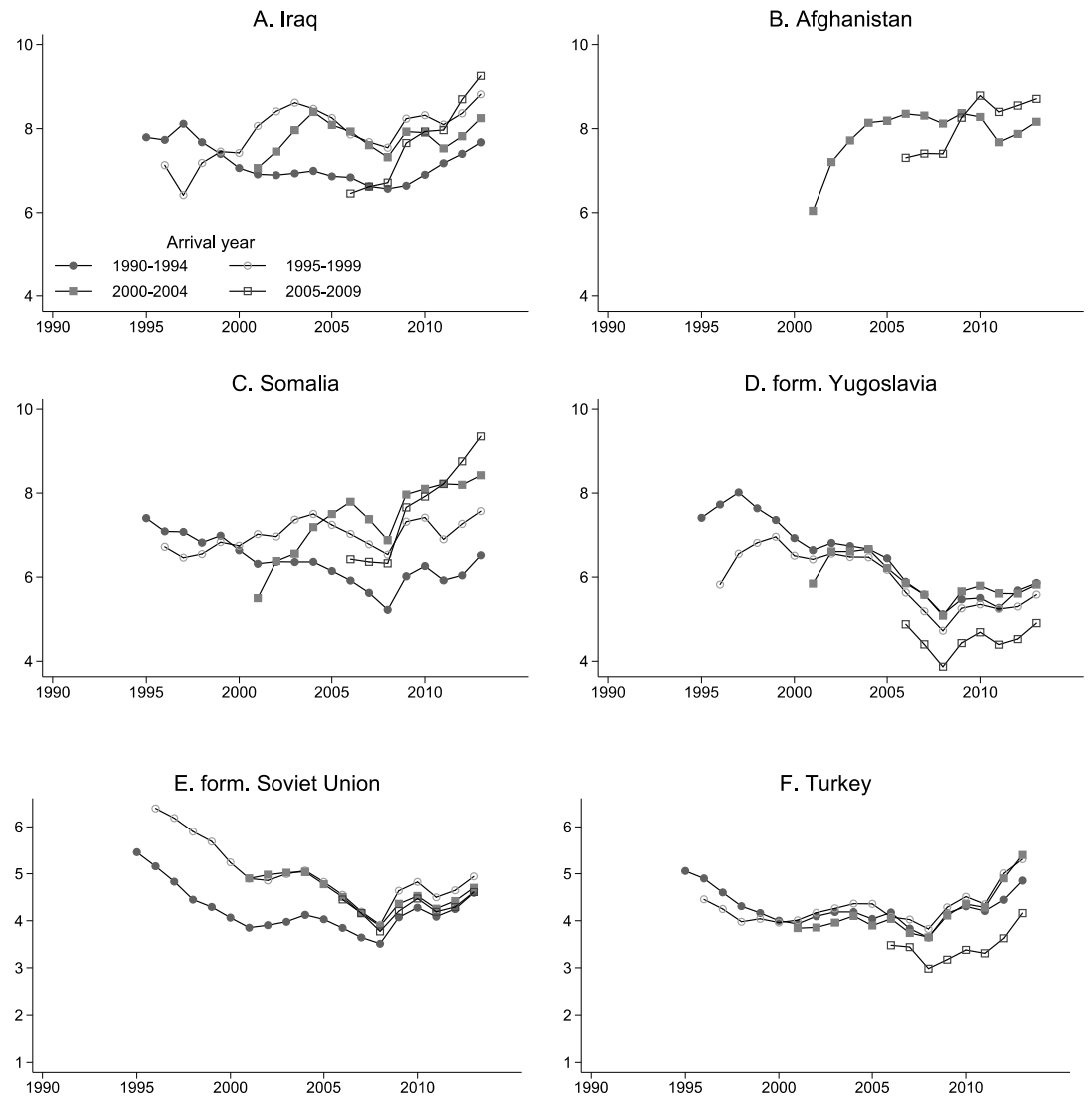

G. OECD

H. Other
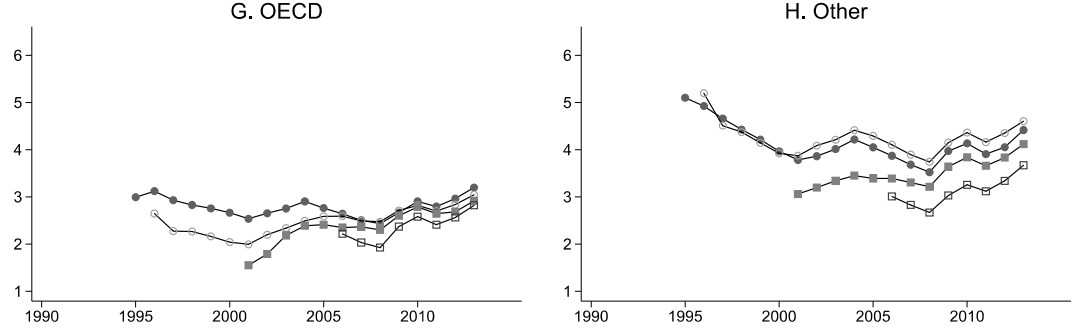

Note: This figure presents time-series for equivalence-scaled annual benefits received by immigrant and his/her household for 25-60 year old individuals who immigrated at age 18 or older.

Source: See section 3.4. 
Table 4: Relative annual equivalence scaled benefits over time lived in Finland

\begin{tabular}{|c|c|c|c|c|c|c|c|c|}
\hline & \multicolumn{4}{|c|}{ Men } & \multicolumn{4}{|c|}{ Women } \\
\hline \multirow{3}{*}{ Iraq } & 1 & 5 & 10 & 15 & 1 & 5 & 10 & 15 \\
\hline & 2.12 & 2.40 & 2.18 & 2.11 & 2.31 & 2.64 & 2.48 & 2.40 \\
\hline & $(0.02)$ & $(0.03)$ & $(0.04)$ & $(0.04)$ & $(0.02)$ & $(0.03)$ & $(0.03)$ & $(0.06)$ \\
\hline \multirow[t]{2}{*}{ Afghanistan } & 2.21 & 2.26 & 1.94 & . & 2.40 & 2.88 & 2.32 & . \\
\hline & $(0.04)$ & $(0.05)$ & $(0.07)$ & & $(0.03)$ & $(0.04)$ & $(0.07)$ & \\
\hline \multirow[t]{2}{*}{ Somalia } & 2.10 & 1.96 & 1.93 & 1.72 & 2.15 & 2.38 & 2.28 & 2.03 \\
\hline & $(0.02)$ & $(0.02)$ & $(0.03)$ & $(0.03)$ & $(0.03)$ & $(0.03)$ & $(0.03)$ & $(0.04)$ \\
\hline Yugoslavia & 1.40 & 1.78 & 1.67 & 1.42 & 1.72 & 2.15 & 1.95 & 1.76 \\
\hline (former) & $(0.02)$ & $(0.02)$ & $(0.03)$ & $(0.03)$ & $(0.03)$ & $(0.03)$ & $(0.03)$ & $(0.05)$ \\
\hline Soviet Union & 1.22 & 1.10 & 1.01 & 0.95 & 1.59 & 1.46 & 1.36 & 1.24 \\
\hline (former) & $(0.01)$ & $(0.01)$ & $(0.01)$ & $(0.02)$ & $(0.01)$ & $(0.01)$ & $(0.01)$ & $(0.01)$ \\
\hline \multirow[t]{2}{*}{ Turkey } & 1.09 & 1.07 & 1.20 & 1.24 & 1.33 & 1.58 & 1.63 & 1.61 \\
\hline & $(0.02)$ & $(0.02)$ & $(0.03)$ & $(0.03)$ & $(0.04)$ & $(0.04)$ & $(0.06)$ & $(0.08)$ \\
\hline \multirow[t]{2}{*}{ OECD } & 0.65 & 0.73 & 0.75 & 0.71 & 0.63 & 0.77 & 0.85 & 0.93 \\
\hline & $(0.01)$ & $(0.01)$ & $(0.01)$ & $(0.02)$ & $(0.01)$ & $(0.01)$ & $(0.02)$ & $(0.04)$ \\
\hline \multirow[t]{2}{*}{ Other } & 0.81 & 1.02 & 1.13 & 1.14 & 1.06 & 1.23 & 1.24 & 1.24 \\
\hline & (0.01) & (0.01) & (0.01) & $(0.02)$ & (0.01) & (0.01) & (0.01) & $(0.02)$ \\
\hline \multirow[t]{2}{*}{ All immigrants } & 0.95 & 1.10 & 1.16 & 1.14 & 1.25 & 1.39 & 1.39 & 1.32 \\
\hline & $(0.00)$ & (0.01) & (0.01) & (0.01) & $(0.00)$ & (0.01) & $(0.01)$ & $(0.01)$ \\
\hline
\end{tabular}

Note: This table reports average relative benefits of immigrants in comparison to natives of the same age and gender (see note for Table 3 for details). Bootstrapped standard errors (in parentheses) are calculated using 100 replications using data for a random sample of $10 \%$ of natives and the full population of immigrants.

Source: See section $3 \cdot 4$.

The differences in the evolution of relative earnings and benefits are likely to reflect the complexity of the benefit system. Benefits are a function of household composition, the earnings of all members of the household (for some, but not all benefits), housing costs and so forth. Furthermore, higher earnings do not typically lead to a one-to-one reduction in benefits even in the case of single-person households. The patterns documented above highlight the importance of both labor market integration and the details of the tax and benefit systems for the fiscal impacts of immigration. However, a full investigation of the interaction between earnings and benefits is beyond the scope of this paper. 


\subsection{Conclusions}

This paper presented an overview of Finland's policy response to the increase in asylum applications in 2015 and documented the employment, earnings and benefits of earlier immigrant cohorts. The two topics are closely related as the policy responses following the 2015 inflows were largely motivated by the perception that earlier refugees had not integrated well into the Finnish labor market and thus constituted a burden on public finances.

The results reported in this paper are largely in line with this view. I find that earlier cohorts of immigrants from the main source countries of the 2015 asylum seekers Iraq, Afghanistan and Somalia - had substantially lower employment rates and average earnings and collected more social benefits than natives. While the immigrant-native gap decreased over the first decade lived in Finland, it remained substantial. Furthermore, the differences in benefits remained roughly constant despite the increase in immigrants' employment rates and earnings.

Of course, asylum seekers arriving in 2015 may differ from earlier cohorts from the same countries. Furthermore, the new approaches in integration policies that Finland is currently adopting may be more efficient than previous policies. Nevertheless, it seems reasonable to expect that also the newly arrived asylum seekers will face challenges in establishing themselves in the Finnish labor market.

\section{References}

Barth, E., Bratsberg, B., and Raaum, O. (2004), Identifying earnings assimilation of immigrants under changing macroeconomic conditions, Scandinavian Journal of Economics 106, 1-22.

Borjas, G.J. (1999), The economic analysis of immigration, in O.C. Ashenfelter and D. Card (eds), Handbook of Labor Economics 3A, 1697-1760, Elsevier.

Dustmann, C., and Görlach, J-P. (2015), Selective out-migration and the estimation of immigrants' earnings profiles, in B.R. Chiswick and P.W. Miller (eds), Handbook of the Economics of International Migration, Volume 1A, 489-533, Elsevier.

Edin, P. A., LaLonde, R. J., and Åslund, O. (2000), Emigration of immigrants and measures of immigrant assimilation: evidence from Sweden, Swedish Economic Policy Review 7, 163-204.

Kerr, S. and Kerr, W.R. (2011): Economic impacts of immigration: a survey. Finnish Economic Papers 24, 1-32. https://doi.org/10.3386/w16736 
Martikainen, T., Saari, M and Korkiasaari, J (2013), Kansainväliset muuttoliikkeet ja Suomi, in T. Martikainen et al. (eds.) Muuttajat. Kansainvälinen muuttoliike ja suomalainen yhteiskunta. Gaudeamus, Helsinki.

Nielsen, H. S., Rosholm, M., Smith, N., and Husted, L. (2004), Qualifications, discrimination, or assimilation? An extended framework for analysing Immigrant wage gaps, Empirical Economics 29, 855-883. https://doi.org/10.1007/s00181-004-0221-9

Pihkala, K. U. (1952), The land settlement program of Finland. Land Economics 28, 147-159.

Salminen, S. (2015), Maahanmuutot ja Suomen julkinen talous. Osa I: Toteutuneet julkisen talouden tulot ja menot. Suomen Perusta, Helsinki.

Sarvimäki, M. (2011), Assimilation to a welfare state: labor market performance and use of social benefits by immigrants to Finland. Scandinavian Journal of Economics 113, 665-688.

Sarvimäki, M., Uusitalo, R. and Jäntti, M. (2016), Habit formation and the misallocation of labor: evidence from forced migrations. Working paper. https://doi.org/10.1111/j.1467-9442.2011.01652.x

Waris, H., Jyrkilä, V., Raitasuo, K. and Siipi, S. (1952), Siirtoväen sopeutuminen. Otava, Helsinki. 


\section{Appendix}

Table A1: Differences in employment rates over time lived in Finland, all immigrants vs. "stayers"

\begin{tabular}{|c|c|c|c|c|c|c|c|c|c|}
\hline \multirow{5}{*}{ Iraq } & \multirow{3}{*}{ All } & 1 & 5 & 10 & 15 & 1 & 5 & 10 & 15 \\
\hline & & -0.71 & -0.59 & -0.48 & -0.50 & -0.69 & -0.66 & -0.65 & -0.63 \\
\hline & & (0.01) & (0.01) & $(0.01)$ & $(0.02)$ & (0.01) & $(0.01)$ & (0.01) & $(0.02)$ \\
\hline & \multirow[t]{2}{*}{ Stayers } & -0.71 & -0.58 & -0.47 & -0.49 & -0.69 & -0.66 & -0.64 & -0.63 \\
\hline & & (0.01) & $(0.01)$ & $(0.01)$ & $(0.02)$ & $(0.01)$ & (0.01) & (0.01) & $(0.02)$ \\
\hline \multirow[t]{4}{*}{ Afghanistan } & \multirow[t]{2}{*}{ All } & -0.72 & -0.47 & -0.38 & . & -0.74 & -0.66 & -0.57 & . \\
\hline & & $(0.02)$ & $(0.03)$ & $(0.03)$ & & (0.01) & $(0.02)$ & (0.03) & \\
\hline & \multirow[t]{2}{*}{ Stayers } & -0.73 & -0.45 & -0.36 & . & -0.74 & -0.66 & -0.57 & . \\
\hline & & $(0.02)$ & $(0.04)$ & $(0.04)$ & & (0.01) & $(0.02)$ & $(0.03)$ & \\
\hline \multirow[t]{4}{*}{ Somalia } & \multirow[t]{2}{*}{ All } & -0.65 & -0.57 & -0.48 & -0.48 & -0.66 & -0.66 & -0.68 & -0.66 \\
\hline & & (0.01) & $(0.01)$ & $(0.01)$ & $(0.02)$ & $(0.00)$ & (0.01) & (0.01) & (0.01) \\
\hline & \multirow[t]{2}{*}{ Stayers } & -0.66 & -0.56 & -0.45 & -0.44 & -0.67 & -0.66 & -0.67 & -0.64 \\
\hline & & $(0.01)$ & $(0.02)$ & $(0.02)$ & $(0.02)$ & (0.01) & (0.01) & (0.01) & (0.02) \\
\hline \multirow{4}{*}{$\begin{array}{l}\text { Yugoslavia } \\
\text { (former) }\end{array}$} & \multirow[t]{2}{*}{ All } & -0.58 & -0.41 & -0.27 & -0.18 & -0.64 & -0.58 & -0.47 & -0.37 \\
\hline & & (0.01) & $(0.01)$ & (0.01) & (0.01) & (0.01) & $(0.01)$ & (0.01) & $(0.02)$ \\
\hline & \multirow[t]{2}{*}{ Stayers } & -0.57 & -0.38 & -0.25 & -0.15 & -0.65 & -0.58 & -0.46 & -0.34 \\
\hline & & (0.01) & $(0.01)$ & $(0.01)$ & $(0.02)$ & $(0.01)$ & (0.01) & (0.01) & (0.02) \\
\hline \multirow{4}{*}{$\begin{array}{l}\text { Soviet } \\
\text { Union } \\
\text { (former) }\end{array}$} & \multirow[t]{2}{*}{ All } & -0.38 & -0.21 & -0.15 & -0.12 & -0.55 & -0.37 & -0.22 & -0.17 \\
\hline & & (0.01) & (0.01) & (0.01) & (0.01) & $(0.00)$ & $(0.00)$ & (0.00) & (0.01) \\
\hline & \multirow[t]{2}{*}{ Stayers } & -0.40 & -0.17 & -0.13 & -0.12 & -0.56 & -0.36 & -0.21 & -0.16 \\
\hline & & (0.01) & (0.01) & (0.01) & (0.01) & $(0.00)$ & $(0.00)$ & (0.01) & (0.01) \\
\hline \multirow[t]{4}{*}{ Turkey } & \multirow[t]{2}{*}{ All } & -0.30 & -0.20 & -0.17 & -0.17 & -0.61 & -0.58 & -0.56 & -0.53 \\
\hline & & $(0.02)$ & (0.01) & (0.01) & (0.01) & (0.02) & $(0.02)$ & $(0.03)$ & $(0.03)$ \\
\hline & \multirow[t]{2}{*}{ Stayers } & -0.28 & -0.17 & -0.15 & -0.16 & -0.63 & -0.59 & -0.55 & -0.51 \\
\hline & & $(0.02)$ & $(0.01)$ & (0.01) & $(0.02)$ & $(0.02)$ & $(0.02)$ & $(0.03)$ & $(0.04)$ \\
\hline \multirow[t]{4}{*}{ OECD } & \multirow[t]{2}{*}{ All } & -0.18 & -0.19 & -0.14 & -0.11 & -0.31 & -0.32 & -0.26 & -0.22 \\
\hline & & (0.01) & (0.01) & (0.01) & (0.01) & (0.01) & $(0.01)$ & (0.01) & $(0.02)$ \\
\hline & \multirow[t]{2}{*}{ Stayers } & -0.12 & -0.10 & -0.10 & -0.09 & -0.25 & -0.24 & -0.22 & -0.19 \\
\hline & & (0.01) & (0.01) & (0.01) & (0.01) & (0.01) & $(0.01)$ & (0.01) & $(0.02)$ \\
\hline \multirow[t]{4}{*}{ Other } & \multirow[t]{2}{*}{ All } & -0.32 & -0.28 & -0.22 & -0.20 & -0.45 & -0.34 & -0.24 & -0.19 \\
\hline & & (0.00) & (0.01) & $(0.00)$ & (0.01) & $(0.00)$ & $(0.00)$ & $(0.00)$ & (0.01) \\
\hline & \multirow[t]{2}{*}{ Stayers } & -0.33 & -0.23 & -0.19 & -0.18 & -0.46 & -0.32 & -0.22 & -0.18 \\
\hline & & (0.01) & $(0.01)$ & $(0.00)$ & (0.01) & (0.01) & (0.01) & (0.01) & (0.01) \\
\hline \multirow[t]{4}{*}{ Everyone } & \multirow[t]{2}{*}{ All } & -0.34 & -0.28 & -0.22 & -0.20 & -0.50 & -0.39 & -0.28 & -0.23 \\
\hline & & $(0.00)$ & $(0.00)$ & $(0.00)$ & (0.00) & $(0.00)$ & $(0.00)$ & (0.00) & (0.00) \\
\hline & Stayers & -0.36 & -0.23 & -0.19 & -0.18 & -0.52 & -0.37 & -0.26 & -0.22 \\
\hline & & $(0.00)$ & $(0.00)$ & $(0.00)$ & $(0.00)$ & $(0.00)$ & $(0.00)$ & (0.00) & (0.00) \\
\hline
\end{tabular}

Note: This table reports immigrant-native employment gaps (see the note to Table 2 for details). In each panel, the top entry reports results using data for all immigrants who arrived to Finland in 1990-2002; the bottom entry reports the estimates for immigrants who stayed in Finland for at least ten years.

Source: See section 3.4 . 


\title{
4. Labour market entry of non- labour migrants - Swedish evidence $^{29}$
}

Olof Åslund, Anders Forslund, and Linus Liljeberg

\begin{abstract}
We describe the short- and long-term patterns of labour market entry and integration among Non-Western, predominantly non-labour, immigrants to Sweden. Our main sample considers the 1990-2014 period. The patterns of time to first contact and labour market entry vary with business cycle conditions, country of origin and other background characteristics. But the main message is the remarkable stability of a relatively slow entry process and long-term outcomes below those of the average worker. The number of jobs before the "first real job" (entry) is limited and the first employer contact is for many a port to a more stable position. First jobs are comparatively often found in small, low-wage firms, which over time have become increasingly present in service industries. Our discussion of policy experiences suggests several margins and factors affecting the labour market outcomes of recent migrants, but also indicate that no single reform or measure is likely to in itself radically change the patterns.
\end{abstract}

- JEL codes: J61, J68

- Keywords: immigration, labour market entry, integration policy

${ }^{29}$ We are grateful for comments from Anna Piil Damm and two anonymous referees. 


\subsection{Introduction}

Refugee immigration to Sweden has been sizeable for a long time and reached an all time high in 2015 in terms of the number of asylum seekers. The numbers of granted residence permits for refugees have also been high in later years and can be expected to increase in the next few years due to the surge in asylum seekers (see Figure 1). It can furthermore be noted that the number of asylum seeking children was around 70,000 (of which roughly half arrived without their parents) in 2015.

All in all, the numbers of asylum seekers and refugee immigrants are large enough to imply that successful integration will be important not only for the immigrants but also for native Swedes and previous migrants. The recent numbers are also significant in the sense that they imply challenges to a large number of Swedish institutions in the short run. This is obviously true for refugee reception institutions, but also for schools and for the housing market. However, if the integration process should prove to be successful, this would alleviate future labour market problems associated with an aging population and contribute to better long-run public finances. And an unsuccessful integration would instead make such long-run challenges tougher. Hence, there is no doubt that integration will be a key issue in Sweden in the years to come.

In this paper we present integration patterns for earlier cohorts of immigrants to shed light on what we should expect given earlier experiences. Naturally, labour market and political institutions change, and the size and composition (e.g., with respect to age, education, and birth country) of immigration vary. This could decrease the information value of historical patterns for predicting future ones, but it is arguably the best foundation available. Also, with the rich data and long observation period at hand, we are able to look at heterogeneity in many dimensions.

We study the first contacts with the labour market and the process of reaching a more stable employment and earnings position. We also describe in which industries and firms entry occurs, and study the number of jobs and employers met from the first contact until becoming established. The main population under study is immigrants arriving in the 1990-2014 period, from refugee sending countries. We also analyse earnings development and long-term indicators on economic marginalisation for selected region-specific (earlier) cohorts containing substantial inflows of refugees. The paper also contains a description and discussion of policies, reforms and institutions relevant for the labour market prospects of newly arrived migrants. 


\subsection{Refugee migration to Sweden in the post-war period ${ }^{30}$}

Sweden's history as a significant net immigration receiver begins after World War II. In the 1930 census, only $1 \%$ of the population was foreign-born, climbing to $7 \%$ in 1970 and further to $17 \%$ at the end of 2015 .

During and after the war, a substantial number of refugees from neighbouring countries sought shelter in Sweden (which lifted some restrictions against refugee migration during the war). Some arrived from Norway, Denmark and the Baltic countries, whereas others came from concentration camps in continental Europe. These individuals to a high degree returned to their countries of origin or moved to a third country in the late 1940s, but significant proportions also remained in Sweden.

In the 1950 and 1960 labour migration dominated the inflows. Most migrants came from the Nordic countries, especially Finland, where the number of individuals living in Sweden increased by close to 200,000 from 1951-1970. But the period also saw some immigration following political turmoil, e.g. in Hungary (1956), Greece (1967) and Czechoslovakia (1968). The regulations for non-Nordic labour migration became stricter from 1967 and even more so in the early 1970s. A gradual shift then occurred toward refugee and family-related immigration. The 1970 s and early 1980 s saw politically motivated immigration from e.g. Chile, Turkey, Lebanon, Vietnam, and Poland.

During the 1980s, the number of asylum applicants and residence permits granted on humanitarian grounds increased (see Figure 1). Iran, Ethiopia and Chile were significant source countries. In 1989, close to 25,000 individuals immigrated, partly as a result of a new praxis shortening waiting times and preferential treatment of those whose applications had been pending for a long time. As a result, the number of asylum applications rose, which in turn contributed to a tightening of the regulations later the same year. For a couple of years, refugee immigration was somewhat lower, before the Balkan wars caused an unprecedented number of people to go to Sweden for humanitarian reasons. In the summer of 1993 , visa requirements for citizens from Bosnia-Herzegovina and (F.Y.R) Macedonia were enacted to reduce the number of asylum seekers. In 1993-1994 over 80,000 refugees were granted residence in Sweden, whereof 66,000 from former Yugoslavia. Another 20,000 came in these two years as

$3^{\circ}$ We use the term refugees also for asylees and humanitarian residence permit categories. The presentation largely builds on Nilsson (2004) and on official figures from Statistics Sweden and the Swedish Migration Board. See also http://www.motallaodds.org/factualweb/se/2.3/articles/1930_talet.html 
family reunification migrants to previous refugees. As can be seen in Figure 1, this was also a time when falling and negative GDP growth was accompanied/followed by sharply rising unemployment. Another message from the figure is that there is a lot of variation in economic conditions also in later years, meaning that the cohorts we study have faced varying prospects at arrival.

Throughout the 1990s, there was also a substantial and persistent inflow of people from Iraq, and (particularly in the early part of the decade) Somali refugees also became a significant refugee group. Iraqis continued to come in the 2000s, with peaks in the 2006-2007 period. Somali refugee migration increased at the same time, but with a somewhat later peak. Even though the presentation here mentions only a few countries, it is important to note that there is a wide distribution of citizenships among asylum seekers to Sweden. While it may dominate the inflow in one or two consecutive years, no single group has done so seen over a longer time period.

With some variation, the trend has been toward steadily growing overall immigration since the mid 1980 , reaching more than 100,000 residence permits per year from 2012. Refugees and their families have constituted on average $25-30 \%$ of this figure since the year 2000, but growing in recent years. Since 2000, women have made up $30-40 \%$ of the asylum seekers annually. Children constituted about one quarter of the applicants before the number of unaccompanied minors grew from about 2 to $8 \%$ from 2008.

Much due to the war in Syria and other conflicts in the region, the total number of asylum seekers increased annually from 2011 to 2014. In 2015, projections in the first part of the year signalled that the number of applications would fall below that of 2014 . But in late summer things changed and the inflows increased rapidly, reaching 8,00010,000 applications weekly in October and November. The Swedish government took dramatic steps, which combined with changes outside Sweden sharply decreased the number of people seeking asylum in Sweden. Many decisions are still pending, so the total impact of the 2014-2015 asylum applications on refugee immigration is still to be seen. In 2016, a total of 67,000 individuals were granted asylum. As of January 2017, 122,000 people were registered in the Migration Board's reception system.

This short description again illustrates that refugee migration is much driven by external dramatic events, but occurs also in interplay with legal frameworks, where developments proceed and follow interchangeably. While the legal distinction between e.g. refugees and labour migrants is typically clear-cut, an individual migrant's decision may well be affected by several factors of different types (e.g. social and economic 
hardship in combination with political oppression). The legal frameworks affecting migration is also likely to play an important role, and one can expect people to follow the route that is more open and feasible.

Figure 1: Asylum seekers, residence permits, and unemployment 1984-2015

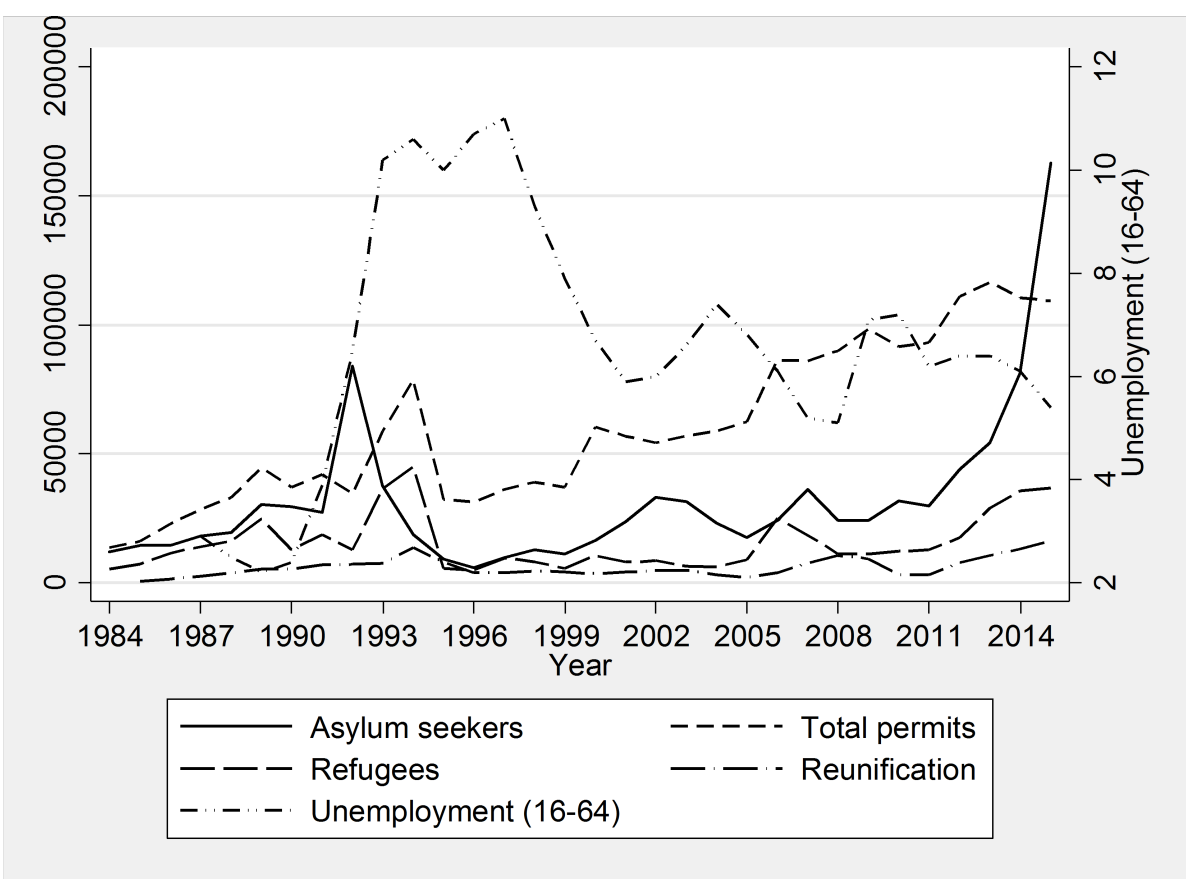

Source: The Swedish Migration Board, Statistics Sweden (Labour Force Surveys).

\subsection{Some data issues and definitions}

In this study, we are interested in immigration to Sweden that is not driven by persons from other countries finding jobs who subsequently decide to move to Sweden (immigration for labour market reasons). While integration issues can certainly be important in relation to labour market driven immigration, it may be argued that the most interesting issues regarding labour migrants relate to their impact on natives through an increased labour supply in certain segments of the labour market, and to the overall economy. We do not deal with such issues in this study. Instead, we focus on 
the labour market integration of immigrants who arrive either as refugees or as relatives of refugees (recent or past). For these immigrants, labour market integration is a key issue. Hence, we look at different measures of labour market integration of nonlabour immigrants and how these measures evolve over time.

We do not have any direct information on type of residence permit. Instead we use birth country (or birth region) to define the population of interest. We consider mainly individuals from non-European countries outside the OECD except for the period of wars in former Yugoslavia as refugees or related to refugees; see the appendix for details. Since we use a long time period there will be cases where the characteristics of the migration change over time; any inclusion/exclusion is thus an approximation.

Our main sample consists of first time immigrants born in the countries listed in Table A2, age 20-50 at immigration in the years 1990-2014, followed from receipt of residence permit ${ }^{31}$ (i.e. the formal time of immigration), at most to age 65 . In section 4.6 we use a different sample, consisting of selected region of origin/year of arrival groups, intended to capture specific refugee inflows followed over an even longer period of time (these individuals may have immigrated before 1990 and are not always followed from immigration).

The baseline sample includes more than 500,000 individuals (see Table A3), the mean age at immigration is 31 and men and women are equally represented. Looking at all cohorts in a 2014 cross-section we see that the level of education varies across cohorts and origin groups, but that about one third has acquired tertiary education (prior to or after immigration). Information on education is missing for a substantial fraction of the different samples, indicating that some caution is warranted due to potential measurement error also for those where we have information.

Both our samples contain a significant share of family reunification migrants. We believe that the economic integration of this broader immigrant group is relevant for our purposes, and given that the regulations and conditions for family migration has varied over time, we arguably avoid some sample composition issues by including a broader group. What could be worrying is that the sample will also contain some labour and education migrants. A comparison with official immigration statistics does

${ }^{31}$ We do not observe people when they apply for asylum (arrive in Sweden); immigration occurs (by definition) if/when the residence permit is granted and then observation begins. As the process of getting a residence permit tends to be lengthy, we systematically underestimate the durations of immigrants' actual stay in Sweden. However, our definition of immigration corresponds to the formal one, which also defines much of the support available to the newly arrived. 
however suggest that immigration from the countries included in the analysis is strongly dominated by refugees and reunification with former humanitarian migrants. The correlation in inflows by region-of-origin/year-of-immigration in our sample and the overall statistics is in the order of 0.9 ; thus our sample closely mirrors humanitarian and reunification migration from the included source countries..$^{32}$

We consider labour market integration as a process potentially involving many steps. To describe this process, we walk through it step by step to see how they are taken by different groups of immigrants and whether the outcomes change over time. We start with the first contacts with the labour market: how long does it take before an individual reports positive earnings (no matter how small, this is defined as the first job) or we can observe indications on the first attempt to look for jobs by registering at the Public Employment Service (PES)?

We then look at how long it takes to labour market entry, defined here as having "the first real job", which in our setup is the first year that a person has annual earnings in excess of half the median annual earnings of a 45 year-old. ${ }^{33}$ Hence, we sum up the labour earnings during a given year. This means that an individual may have more than one job the year (s)he gets established. As we look at the way into the labour market, this is natural. The threshold is chosen high enough to rule out short temporary jobs, but low enough to allow for low-paid full-time jobs during a substantial part of the year.

Furthermore, we characterise both the first jobs and the entry jobs in terms of industries, firm sizes, and whether firms are high-paying or low-paying ones. We also look at integration in terms of the development of the position in percentile ranked income distributions over time since immigration.

$3^{2}$ Details available upon request. Due to data availability the comparisons are done for the 2004-2014 period. Most likely, issues caused by other forms of immigration are even smaller in previous cohorts.

33 This is the definition used by Erikson et al. (2007). The earnings threshold roughly corresponds to six monthly wages for a full-time janitor in the local public sector. 
Finally, we use register data to look at some complementary outcomes which primarily reflect integration problems: social assistance take-up, employment and earnings in the long-term. In this part of the analysis, we focus on the alternative sample with specific region-of-origin/year-of-arrival categories, which constituted significant refugee inflows from varying parts of the world.

\subsection{Labour market integration: How long does it take?}

In this section, we present evidence on how long time the different steps taken during the labour market entry process take.

\subsubsection{First labour market contacts}

A natural indicator on the first contact with the labour market is the receipt of the first earnings. The left panel of Figure 2 displays the fraction of different immigrant cohorts (1992-2014) having had their first earnings 1, 3, 5, 10 and 15 years after immigration. For a given cohort, the different lines present the cumulated experience (since they display the fraction with positive earnings on at least one point, they can never cross). A number of features are worth mentioning. First, the importance of business cycle conditions is clearly visible in the low shares having a first contact within 1 and 3 years after immigration for cohorts arriving in the early 1990s. A similar indication is the drop for immigrants entering around the financial crisis of 2009. Second, the share rises continuously with the duration of the stay in Sweden and reaches around 90\% after 10 to 15 years. Third, after the year 2000 there is no clear trend across the immigration cohorts in the timing of the first earnings, especially looking at shares for those who have had their residence permits for at least five years. This suggests that the timing of the first contact is not very sensitive to, e.g., the number of residence permits granted (see Figure 1) or "normal" changes in business cycle conditions. 
Figure 2: Fraction having had positive earnings and/or having registered with the PES, at different number of years since immigration, by cohort

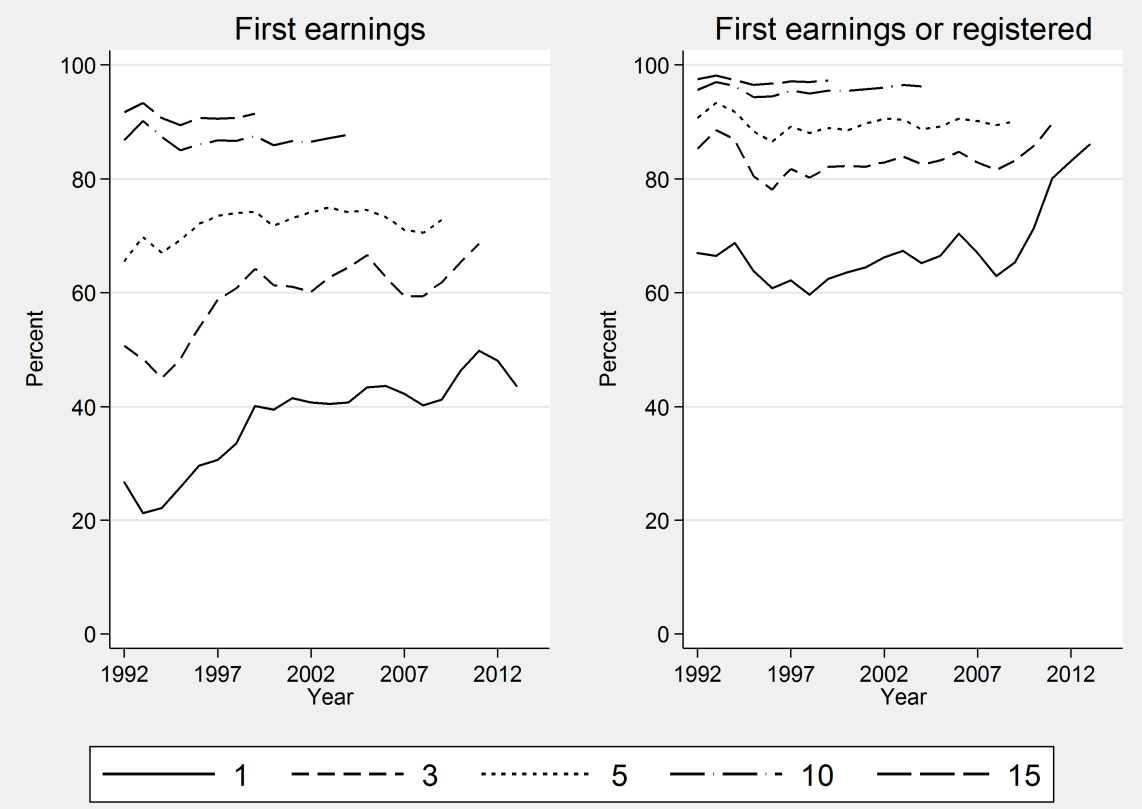

A drawback with first earnings is that it captures success, not necessarily labour force participation. To get a more complete measure of the first contacts with the labour market, the right-hand panel of Figure 2 shows the share of migrants who have had their first earnings and/or registered with the PES at some point in time. A common first step into the Swedish labour market is to register as a job seeker at the PES, and the combined measure clearly give higher values than for earnings only. In the 1990 and early 2000s, the fraction having registered or receiving earnings in the first year after immigration was around 60-70\%. Particularly from 2011 (Dec 2010), when the responsibility for refugee reception and integration was transferred from the municipalities to the PES, we see increasing fractions of immigrants with early contacts with the PES.

In sum, the figures suggest that a majority of the immigrants take some form of step toward the labour market relatively soon after immigration, but that successful 
labour market contacts may take longer. This is something we will address further below, when we look at labour market entry.

\subsubsection{Labour market entry - the "first real job"}

Figure 3 shows the same type of information as Figure 2, but with a higher threshold requiring earnings of at least half the medium earnings of a 45 -year-old. It is evident from the figure that labour market entry is a time-consuming process - it takes more than five years for half a cohort of immigrants to enter the labour market. However, after 15 years around $80 \%$ in the cohorts have completed the labour market entry. As for the first contacts, business cycle conditions matter. If anything, they seem to matter more for entry than for the first contact. ${ }^{34}$ There is no indication that the process has deteriorated over time; in the longer perspective the opposite seems to be the case. The dip in the 1-year curve after 2011 could be a negative signal. But PES statistics on the fraction of refugees and reunification migrants in education or work 90 days after completing the introduction program continue to show small increases up to and including 2016.35 Combining the information in Figure 2 with the information in Figure 3 , it is hard to see a systematic relationship between the number of immigrants in a cohort and labour market success, as measured by time to labour market entry.

A relevant question is of course whether what we label "entry" is temporary or permanent. An indication is given by a comparison of long-term patterns conditional on previous entry. Looking at those who met the earnings criterion in at least one year within the first three, about two-thirds meet the criterion in any given later year. In other words, entry is clearly linked to future prospects, but there is also a substantial fraction that go back to lower earnings. ${ }^{36}$

The progress of different cohorts can in Figure 3 be traced through comparison of the curves for different years. Our graphs facilitate comparison across cohorts but

\footnotetext{
34 This suggests that scarring might be more significant for searching, getting and keeping "real" jobs than for more occasional labour earnings.

35 See https://www.arbetsformedlingen.se/download/18.546b84d6158f5eeo776d39d3/1484315786121/tabellbilaga-statistiketableringsuppdraget.pdf, accessed January 16, 2016.

${ }^{36}$ If involuntary job loss is more common among immigrants than among natives, this may mean different kinds of job mobility among immigrants than among natives, probably implying less upward wage mobility among immigrants (see Barth et al., 2012, for an empirical analysis of the Norwegian labour market along such lines). Such an empirical analysis of job stability is, however, beyond the scope of this paper.
} 
deviates from traditional ways of presenting e.g. employment and earnings assimilation (cf. section 4.7 below). If we instead compute weighted standardized employment differences by years since migration along the lines of Sarvimäki (2017, this issue), we find a well-known assimilation pattern for the average migrant in the 1990-2014 cohorts; see Figure A1. The initial differential is in the order of 70 percentage points, then falls rapidly to 42 percent after five years and 27 percent after ten years. The difference then levels off, but remains at 20 percentage points also after 20 years. The employment gap is larger for women than for men, especially 5-10 years after immigration. ${ }^{37}$

Figure 3: Fraction of immigrants who have entered the labour market at different numbers of years since immigration, by cohort

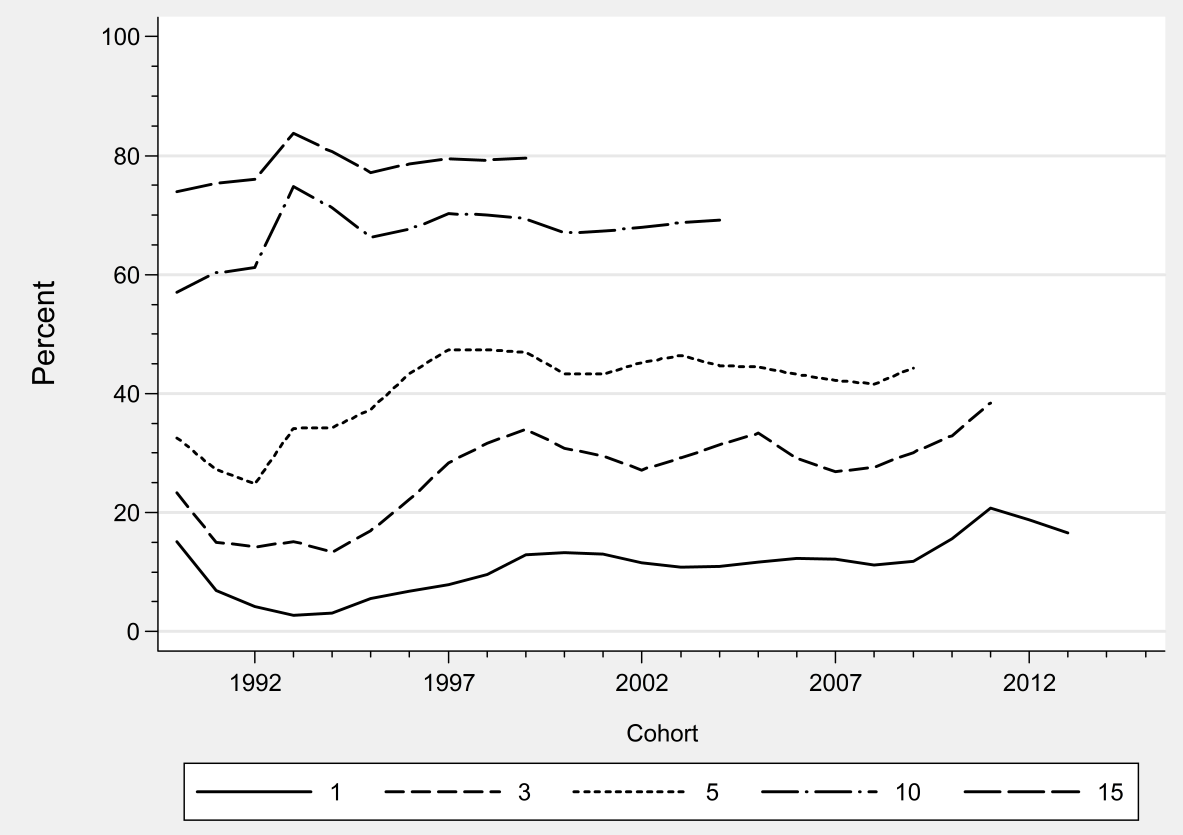

37 Statistics on employment by years since migration for the 1997-1999 refugee cohorts presented in OECD (2016) fall close to our results. OECD reports an employment rate of 50 (40) percent for refugee men (women) after 5 years, and after 10 years it is somewhat above (at) 60 percent. 


\subsubsection{Differences between source countries and groups of immigrants}

The averages presented in sections 4.1 and 4.2 hide some differences between different source countries and groups of immigrants. First, country of origin seems to be potentially important both for the time to the first job and to labour market entry. We illustrate this in Figure 4, which compares immigrants from former Yugoslavia with immigrants from Iraq. The differences are striking, both regarding the first contact and, especially, labour market entry with integration running much smoother for immigrants from former Yugoslavia than from Iraq. The choice of these two groups is for illustrative purposes; there are similar differences between other groups and it is a common finding that country of origin in a statistical sense explains much of the differences seen in the labour market among recent migrants (see also the regressions presented below). This suggests that country of origin may be important in the integration process.

Given that many recent refugees come from Syria and Afghanistan, it may be of particular relevance to look at the later cohorts for people from this region. The longterm positive trend for Iraqis is also found for other countries in the Middle East but in the very last years of observation there is a dip e.g. among Syrians. One interpretation could be that the Swedish labour market has probably not become less accessible for these groups of migrants, but cohorts dominated by war refugees may be expected to have a slower transition into employment than their countrymen arriving under different circumstances. 
Figure 4: First contacts and entry, immigrants from Iraq and former Yugoslavia at different years since immigration, by cohort
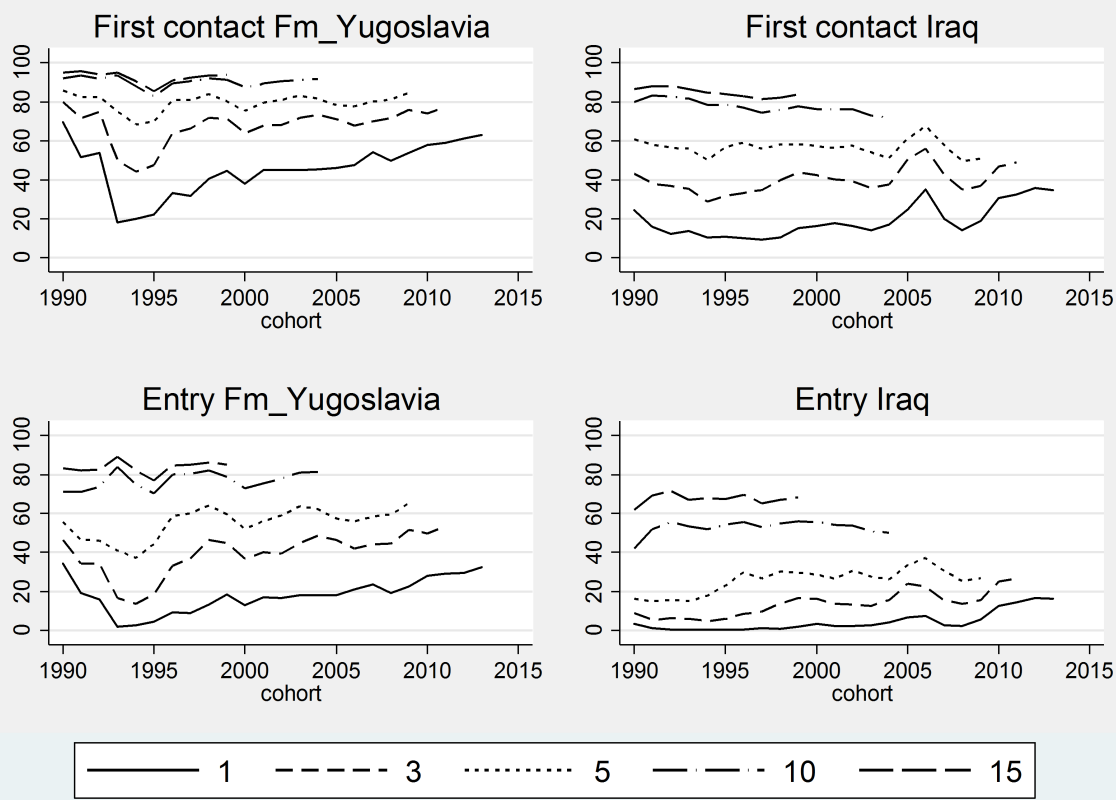

We have also computed labour market entry patterns for other subgroups of the studied immigrant cohorts. We summarise the results of these computations here. Looking at age at the time of immigration, it seems that young persons (age 20-29) enter the labour market somewhat faster than the average (age 20-50), but the differences are relatively modest, both regarding first contacts an entry. Gender differences follow an expected pattern: men on average have a shorter time to their first contact with an employer, and also have substantially shorter times to entry. And for most cohorts and time spans since immigration, the share of men who have entered the labour market exceeds the female share by 10-20 percentage points (Figure 5). Finally, labour market entry is faster the higher the level of educational attainment. This is especially true when comparing immigrants with at most compulsory education with those having completed upper secondary education. All in all, this suggests that across-group differences typically seen in the overall workforce are also found for recent migrants. 
Figure 5: Fraction of immigrants who have entered the labour market at different years since migration, women and men by cohort
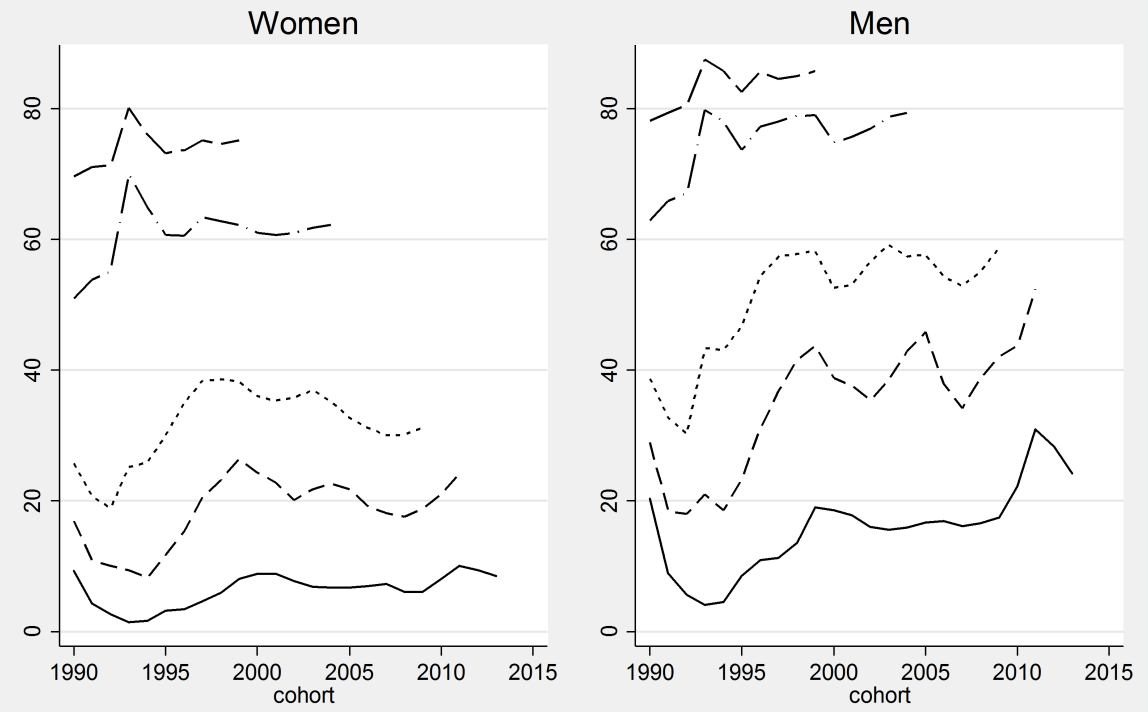

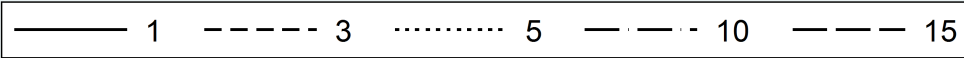

\subsubsection{Durations and employers on the way to entry}

Table 1 shows average times to first jobs, labour market entries and durations between first jobs and entry for different cohorts. The left (right) columns present figures for people entering the labour market within 5 (10) years after immigration. The reason for analyzing conditional samples is to get comparability across cohorts. For this reason we cannot display results for cohorts after 2009 (2004).

The average time elapsed between residence permit and the first contact varies over the years. Most clearly it increased sharply during the economic crisis of the 1990s, and then saw a falling trend before levelling out around 2005. For the 5-year sample, the time elapsed between first contact and entry is very stable across cohorts, again signalling that the first contact is an important step toward a more stable position in 
the labour market. In the 10-year sample all durations become longer as expected, but most of the results are similar..$^{38}$

Table 1 also reports the fraction of cases where the first contact occurs in the same firm as labour market entry. This fraction is quite high and stable across cohorts. In the 5 -year sample figures are $65-70 \%$; for the 10 -year sample where people on average took longer to enter the Swedish labour market, it is still in the order of $60 \%$. If one counts the number of employers involved from first contact to entry (not in the table), the average is between 3.7 and 4.2 throughout the observation period. The median number of jobs held is 3 for all years. ${ }^{39}$ As a comparison, we can notice that Engdahl \& Forslund (2016) showed that youth between 20 and 30 years of age on average had roughly 1.5 jobs per year. Thus, immigrants do not tend to have very large numbers of jobs on their way into the Swedish labour market, neither in absolute nor relative to other groups. This again confirms the importance of the first employer in providing a way forward.

\footnotetext{
${ }^{38}$ The average measures give large weights to long durations. The median is less sensitive to extremes. Looking at medians (not reported in Table 21), median durations are much shorter and generally longer for the time to the first job than the time interval between the first job and entry. Typical values for the medians imply that $50 \%$ of the immigrants have had some contact within 2 years and that $50 \%$ spend at most a year between the first job and labour market entry.

39 The figures are conditional on entry within 8 years after immigration. Relaxing this assumption gives an average (median) around 5 (4) for the early cohorts (with a long follow-up period).
} 
Table 1: Average times between immigration, first labour market contact, and labour market entry; fraction where workplaces of first contact and entry coincide

\begin{tabular}{|c|c|c|c|c|c|c|c|c|}
\hline $\begin{array}{l}\text { Immigrati } \\
\text { on year }\end{array}$ & $\begin{array}{r}\text { Time } \\
\text { (years) } \\
\text { between } \\
\text { immigrati } \\
\text { on and } \\
\text { first } \\
\text { contact, } \\
\text { given } \\
\text { entry } \\
\text { within } 5 \\
\text { years }\end{array}$ & $\begin{array}{r}\text { Time } \\
\text { (years) } \\
\text { between } \\
\text { immigrati } \\
\text { on and } \\
\text { entry, } \\
\text { given } \\
\text { entry } \\
\text { within } 5 \\
\text { years }\end{array}$ & $\begin{array}{r}\text { Time } \\
\text { (years) } \\
\text { between } \\
\text { first } \\
\text { contact } \\
\text { and } \\
\text { entry, } \\
\text { given } \\
\text { entry } \\
\text { within } 5 \\
\text { years }\end{array}$ & $\begin{array}{r}\text { First } \\
\text { contact } \\
\text { and entry } \\
\text { in same } \\
\text { firm, } \\
\text { given } \\
\text { entry } \\
\text { within } 5 \\
\text { years } \\
\text { (percent) }\end{array}$ & $\begin{array}{r}\text { Time } \\
\text { (years) } \\
\text { between } \\
\text { immigrati } \\
\text { on and } \\
\text { first } \\
\text { contact, } \\
\text { given } \\
\text { entry } \\
\text { within } 10 \\
\text { years }\end{array}$ & $\begin{array}{r}\text { Time } \\
\text { (years) } \\
\text { between } \\
\text { immigrati } \\
\text { on and } \\
\text { entry, } \\
\text { given } \\
\text { entry } \\
\text { within } 10 \\
\text { years }\end{array}$ & $\begin{array}{r}\text { Time } \\
\text { (years) } \\
\text { between } \\
\text { first } \\
\text { contact } \\
\text { and } \\
\text { entry, } \\
\text { given } \\
\text { entry } \\
\text { within } 10 \\
\text { years }\end{array}$ & $\begin{array}{r}\text { First } \\
\text { contact } \\
\text { and entry } \\
\text { in same } \\
\text { firm, } \\
\text { given } \\
\text { entry } \\
\text { within } 10 \\
\text { years } \\
\text { (percent) }\end{array}$ \\
\hline 1990 & 0.8 & 2.2 & 1.3 & 69 & 1.8 & 4.5 & 2.7 & 57 \\
\hline 1991 & 1.5 & 2.9 & 1.4 & 65 & 2.7 & 5.6 & 2.9 & 50 \\
\hline 1992 & 1.6 & 3.0 & 1.4 & 65 & 3.0 & 5.8 & 2.8 & 51 \\
\hline 1993 & 2.2 & 3.5 & 1.3 & 67 & 3.3 & 5.6 & 2.2 & 56 \\
\hline 1994 & 2.2 & 3.6 & 1.4 & 65 & 3.3 & $5 \cdot 5$ & 2.2 & 55 \\
\hline 1995 & 2.0 & 3.3 & 1.4 & 65 & 2.9 & 5.0 & 2.1 & 58 \\
\hline 1996 & 1.8 & 3.1 & 1.4 & 64 & 2.5 & 4.5 & 2.1 & 58 \\
\hline 1997 & 1.7 & 3.0 & 1.3 & 67 & 2.4 & 4.4 & 2.0 & 61 \\
\hline 1998 & 1.6 & 2.8 & 1.2 & 69 & 2.3 & 4.2 & 1.9 & 62 \\
\hline 1999 & 1.3 & 2.5 & 1.2 & 70 & 2.0 & 4.0 & 2.0 & 63 \\
\hline 2000 & 1.3 & 2.5 & 1.2 & 71 & 2.1 & 4.1 & 2.0 & 64 \\
\hline 2001 & 1.3 & 2.5 & 1.2 & 71 & 2.0 & 4.1 & 2.1 & 63 \\
\hline 2002 & 1.4 & 2.7 & 1.3 & 70 & 2.1 & 4.2 & 2.2 & 63 \\
\hline 2003 & 1.3 & 2.7 & 1.4 & 68 & 2.0 & 4.2 & 2.2 & 62 \\
\hline 2004 & 1.2 & 2.5 & 1.3 & 68 & 2.0 & 4.1 & 2.2 & 61 \\
\hline 2005 & 1.1 & 2.4 & 1.3 & 68 & & & & \\
\hline 2006 & 1.1 & 2.5 & 1.4 & 69 & & & & \\
\hline 2007 & 1.1 & 2.6 & 1.4 & 71 & & & & \\
\hline 2008 & 1.1 & 2.5 & 1.4 & 73 & & & & \\
\hline 2009 & 1.2 & 2.5 & 1.3 & 73 & & & & \\
\hline
\end{tabular}

Note: For comparability over time, we censor the table. Our last observation is for 2014; hence we censor at 2010 and 2005.

\subsubsection{Immigrants in the earnings distribution}

A common way to measure economic integration of a group is to compare their wages or earnings to other groups (typically natives or the whole population). To avoid comparison problems due to possible changes in earnings inequality in the total distribution of earnings over time, we instead look at the position of different cohorts of immigrants in the percentile ranked earnings distributions from 1990 until 2014. We present evidence in Figure 6 on the earnings distribution conditional on having earnings 
as well as distributions including zero earners (jobless persons). The former is more informative for positions in the wage distribution, while the latter is more informative of income (in)equality between immigrants and natives. Both measures are, of course, related to economic integration.

The left hand-side graph of Figure 6 plots the development of the percentile ranked labour income of the average immigrant with positive income for the immigration cohorts arriving 1990, 1995, 2000, and 2010. There is no clear trend over time, although the 1990 cohort is consistently doing worse than the other cohorts. In this sense integration has been fairly similar since the mid 1990 .

The right hand-side graph of Figure 6 shows the development of the percentile ranked labour income of the average immigrant, including persons with zero incomes, for the same cohorts. Once again, there is no clear trend over time, and here also the 1990 cohort deviates from the others. In fact, the distance to the other cohorts is even larger when we include also the non-employed (with zero income). Previous research suggests that a contributing factor to the fate of the 1990 cohort is that the severe crisis in the Swedish labour market in the 1990s hurt the immigrants both in the short and in the longer run (see Åslund and Rooth, 2007).

We also see that after a rather long period (almost 20 years), the percentile ranked average immigrant labour income only reaches the 45th percentile in the income distribution of the Swedish working age population. Immigrants thus tend to end up in low-paying jobs, and are on average found in even lower income percentiles when we include the non-employed. Hence, in addition to earning relatively little while in employment, these migrants also hold jobs to a lesser extent than native Swedes. In other words, the earnings prospects of previous immigrant cohorts do not reach parity with the overall workforce. This is especially clear considering the fact that we have not adjusted for age profiles in this description. Even for those 20-29 at arrival, who would be expected to have a positive age-earnings profile for most of the follow-up period, the patterns are only marginally more positive than for the overall sample..$^{40}$

$4^{0}$ Notice that the slope of the percentile ranked income curves for the immigrants will reflect possible impacts both of age (experience) and years since migration. Most likely this results in a steeper profile than if an age correction was done. However, such a correction relies on potentially restrictive assumptions. 
Figure 6: Average percentile ranked earnings (excluding and including those with zero earnings) by year of immigration and time spent in Sweden (ysm)

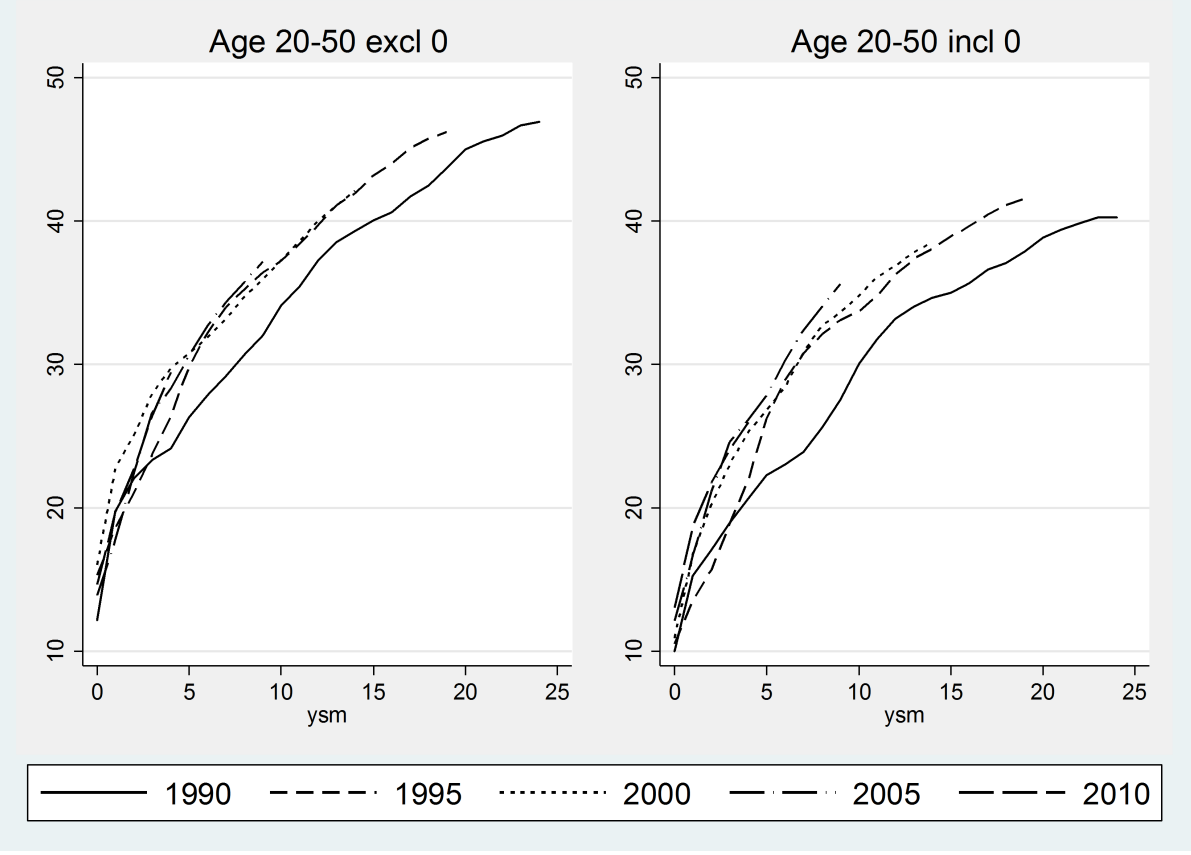

\subsubsection{Multivariate relationships between individual characteristics and labour market outcomes}

In the figures hitherto presented we have typically shown bivariate relationships between different outcomes and different background variables. However, the relationship between two variables (say gender and time to labour market entry) may reflect other factors than only gender, say education. In Table 2, we report the results of multivariate OLS regressions where we regress a number of labour market related outcomes on a number of background characteristics of immigrants. Note that these estimates are for a cross-section of the baseline sample observed in 2014, conditional on year of immigration (and thus time spent in Sweden) and age at arrival. The purpose of this table is to illustrate differences in outcomes between migrants with different characteristics. 
Table 2: Multivariate relationships between individual characteristics and labour market outcomes, OLS regressions

\begin{tabular}{|c|c|c|c|c|c|c|c|}
\hline & $\begin{array}{l}\text { Earnings } \\
2014, \text { SEK }\end{array}$ & $\begin{array}{r}\text { Earnings }> \\
1 \text { price } \\
\text { basic } \\
\text { amount } \\
2014\end{array}$ & $\begin{array}{r}\text { Social } \\
\text { assistance } \\
\text { take-up } \\
2014\end{array}$ & $\begin{array}{r}\text { Social } \\
\text { assistance } \\
2014, \text { SEK }\end{array}$ & $\begin{array}{l}\text { Employed } \\
\text { Nov. } 2014\end{array}$ & $\begin{array}{r}\text { Days } \\
\text { registered } \\
\text { at the PES } \\
2014\end{array}$ & $\begin{array}{r}\text { In PES } \\
\text { register at } \\
\text { least } 10 \\
\text { days } 2014\end{array}$ \\
\hline Woman & $\begin{array}{r}-57985^{* * *} \\
(513)\end{array}$ & $\begin{array}{r}-.15^{* * *} \\
(.001)\end{array}$ & $\begin{array}{r}.06 * * * \\
(.001)\end{array}$ & $\begin{array}{r}8.10 * * * \\
(0.56)\end{array}$ & $\begin{array}{r}-.14^{* * *} \\
(.001)\end{array}$ & $\begin{array}{r}-2.04^{* * *} \\
(0.43)\end{array}$ & $\begin{array}{r}.02 * * * \\
(.001)\end{array}$ \\
\hline South America & $\begin{array}{r}27926 * * * \\
(1431)\end{array}$ & $\begin{array}{r}.09 * * * \\
(.00)\end{array}$ & $\begin{array}{r}-.09 * * * \\
(.003)\end{array}$ & $\begin{array}{r}-28.92 * * * \\
(1.55)\end{array}$ & $\begin{array}{l}.09 * * * \\
(.004)\end{array}$ & $\begin{array}{r}-25.93^{* * *} \\
(1.21)\end{array}$ & $\begin{array}{r}-.06 * * * \\
(.004)\end{array}$ \\
\hline Horn of Africa & $\begin{array}{r}-47379 * * * \\
(989)\end{array}$ & $\begin{array}{r}-.13^{* * *} \\
(.004)\end{array}$ & $\begin{array}{r}.26 * * * \\
(.002)\end{array}$ & $\begin{array}{r}80.98 * * * \\
(1.07)\end{array}$ & $\begin{array}{r}-.14 * * * \\
(.003)\end{array}$ & $\begin{array}{r}83.18 * * * \\
(0.84)\end{array}$ & $\begin{array}{r}.24^{* * *} \\
(.003)\end{array}$ \\
\hline $\begin{array}{l}\text { Arabic peninsula, } \\
\text { North Africa }\end{array}$ & $\begin{array}{r}-41279 * * * \\
(903)\end{array}$ & $\begin{array}{r}-.10 * * * \\
(.003)\end{array}$ & $\begin{array}{r}.08 * * * \\
(.002)\end{array}$ & $\begin{array}{r}19.92 * * * \\
(0.98)\end{array}$ & $\begin{array}{r}-.09 * * * \\
(.003)\end{array}$ & $\begin{array}{r}57.26 * * * \\
(0.76)\end{array}$ & $\begin{array}{r}.16 * * * \\
(.00)\end{array}$ \\
\hline $\begin{array}{l}\text { South and } \\
\text { central Africa }\end{array}$ & $\begin{array}{r}-3354 * * * \\
(1291)\end{array}$ & $\begin{array}{l}.03 * * * \\
(.004)\end{array}$ & $\begin{array}{r}.02 * * * \\
(.003)\end{array}$ & $\begin{array}{r}2.22 \\
(1.40)\end{array}$ & $\begin{array}{r}.02 * * * \\
(.004)\end{array}$ & $\begin{array}{r}10.65^{* * *} \\
(1.09)\end{array}$ & $\begin{array}{r}.06 * * * \\
(.004)\end{array}$ \\
\hline Iran & $\begin{array}{r}-2723^{* *} \\
(1169)\end{array}$ & $\begin{array}{l}-.01 * \\
(.003)\end{array}$ & $\begin{array}{r}.00 \\
(.003)\end{array}$ & $\begin{array}{r}7.14^{* * *} \\
(1.27)\end{array}$ & $\begin{array}{r}-.01 * * * \\
(.003)\end{array}$ & $\begin{array}{r}12.55^{* * *} \\
(0.99)\end{array}$ & $\begin{array}{r}.04^{* * *} \\
(.003)\end{array}$ \\
\hline Iraq & $\begin{array}{r}-51569 * * * \\
(842)\end{array}$ & $\begin{array}{r}-.14^{* * *} \\
(.002)\end{array}$ & $\begin{array}{r}.17^{* * *} \\
(.002)\end{array}$ & $\begin{array}{r}64.03^{* * *} \\
(0.91)\end{array}$ & $\begin{array}{r}-.14^{* * *} \\
(.002)\end{array}$ & $\begin{array}{r}49 \cdot 37^{* * *} \\
(0.71)\end{array}$ & $\begin{array}{r}.16 * * * \\
(.002)\end{array}$ \\
\hline Turkey & $\begin{array}{r}-22320 * * * \\
(1358)\end{array}$ & $\begin{array}{l}-.01 * \\
(.004)\end{array}$ & $\begin{array}{r}-.03 * * * \\
(.003)\end{array}$ & $\begin{array}{r}-9.50 * * * \\
(1.47)\end{array}$ & $\begin{array}{r}-.01 * * * \\
(.004)\end{array}$ & $\begin{array}{r}-1.27^{* * *} \\
(1.15)\end{array}$ & $\begin{array}{l}.01 * * \\
(.004)\end{array}$ \\
\hline South east Asia & $\begin{array}{r}-5720 * * * \\
(1042)\end{array}$ & $\begin{array}{r}.08 * * * \\
(.003)\end{array}$ & $\begin{array}{r}-.10 \\
(.002)\end{array}$ & $\begin{array}{r}-30.14^{* * *} \\
(1.13)\end{array}$ & $\begin{array}{r}.08 * * * \\
(.003)\end{array}$ & $\begin{array}{r}-13.66 * * * \\
(0.88)\end{array}$ & $\begin{array}{r}-.03^{* * * *} \\
(.003)\end{array}$ \\
\hline $\begin{array}{l}\text { Missing } \\
\text { education info. }\end{array}$ & $\begin{array}{r}50082 * * * \\
(3073)\end{array}$ & $\begin{array}{l}.12 * * * \\
(.009)\end{array}$ & $\begin{array}{r}-.16 * * * \\
(.007)\end{array}$ & $\begin{array}{l}-0.86 \\
(3.32)\end{array}$ & $\begin{array}{r}.12 * * * \\
(.009)\end{array}$ & $\begin{array}{r}-252.26 * * * \\
(2.60)\end{array}$ & $\begin{array}{r}-.74^{* * *} \\
(.008)\end{array}$ \\
\hline $\begin{array}{l}\text { Upper secondary } \\
\text { education }\end{array}$ & $\begin{array}{r}7175^{* * *} \\
(2519)\end{array}$ & $\begin{array}{r}.09 * * * \\
(.009)\end{array}$ & $\begin{array}{r}-.06 * * * \\
(.006)\end{array}$ & $\begin{array}{l}4.49^{*} \\
(2.72)\end{array}$ & $\begin{array}{r}.07^{* * *} \\
(.007)\end{array}$ & $\begin{array}{r}39.75^{* * *} \\
(2.13)\end{array}$ & $\begin{array}{r}-.06 * * * \\
(.007)\end{array}$ \\
\hline $\begin{array}{l}\text { Tertiary } \\
\text { education }\end{array}$ & $\begin{array}{r}16915 * * * \\
(2151)\end{array}$ & $\begin{array}{r}.05^{* * *} \\
(.008)\end{array}$ & $\begin{array}{r}-.08 * * * \\
(.005)\end{array}$ & $\begin{array}{r}3.43 \\
(2.33)\end{array}$ & $\begin{array}{r}.04^{* * *} \\
(.006)\end{array}$ & $\begin{array}{r}75.79 * * * \\
(1.82)\end{array}$ & $\begin{array}{r}-.17^{* * *} \\
(.006)\end{array}$ \\
\hline $\begin{array}{l}\text { Mean dep. } \\
\text { Variable }\end{array}$ & 164798 & .47 & .37 & 178.29 & .47 & 139.23 & .45 \\
\hline $\mathrm{N}$ & 441137 & 441137 & 441137 & 441137 & 441137 & 441137 & 441137 \\
\hline
\end{tabular}

Note: Reference categories are men, Former Yugoslavia (some categories excluded from the table), and compulsory education at time for immigration. Significance levels: * $10 \% ; * * 5 \%$; *** $1 \%$. Dummies for calendar year of immigration and age group at immigration also included in estimated models; estimates are not shown here. All covariates are measured at time of immigration. 
Women have worse outcomes than men for all outcomes other than days registered at the PES. We have already shown that there are large differences in outcomes between immigrants from different regions. Our regressions show that this is not only driven by differences in education between migrants from different regions as witnessed by fairly large differences in the estimated associations between region dummies and the different outcomes also when controlling for differences in formal education. Educational attainment at arrival to Sweden is not well measured, and it is not entirely clear what the reference category "missing information" contains. It may be that people who enter the labour market smoothly have lower probabilities to have their education recorded; PES information is e.g. used to update register information on education. ${ }^{41}$ Hence, comparisons between the reference category and the other levels of educational attainment are hard to interpret. Even though there may be measurement error in the education variable, most of estimates are in line with our expectations, meaning that having gone through only compulsory school is associated with worse outcomes than are higher levels of educational attainment.

\subsection{Entry: Where?}

\subsubsection{Industries for first contacts and labour market entry}

Persons who have decided to move to Sweden constitute a heterogeneous group and the composition in terms of observed characteristics changes over time. Hence, we should expect that the mix of sectors and jobs where immigrants enter into the Swedish labour market may have changed for reasons related to changes over time in the supply of different skills of immigrants. In addition, there may have been structural changes in the composition of jobs generating changes in skills demanded over time. All in all, it is not clear what we should expect regarding the industry composition of immigrant employment and its changes over time.

${ }^{41}$ At least $7.7 \%$ in our sample have a higher registered level of educational attainment in year $t+10$ than in year $t+2.15 .5 \%$ have missing information in year $\mathrm{t}+2$ but not in $\mathrm{t}+10$. Whether this reflects that they have taken formal Swedish education or if it reflects that previously acquired education has been registered cannot be determined with the register information used in this study. 
Figure 7 shows the distributions of industries for first contacts and entry jobs, by calendar year of contact/entry (regardless of immigrant cohort). Industries are in the respective graphs ordered on their total share for the four observation years. Business services, hotels and restaurants, manufacturing and health care are the largest suppliers of first contacts as well as entry jobs for immigrants. But looking at the bars within each category, we see some rather dramatic changes over time, where manufacturing has become substantially less important and service industries instead have grown in importance. This partly reflects changes in the overall distribution of employment across industries, but the development is much more pronounced for the inflow of workers than for the stock.

In Table 3 we highlight the difference between men and women in terms of sectors for the first jobs. We see that women are more represented in research and education and, especially, in health care. Men instead more often find their first jobs in manufacturing, hotels and restaurants, and transportation and storage, compared to women. For both genders, business services constitute an important channel for the first contact. This category entails a broad range of activities requiring different levels of qualifications. A look within the category reveals that cleaning services is the by far biggest sub-category, making up 36 (48)\% of the total first contacts (entries) observed in the 1990-2014 period. All other sub-categories are much smaller; the runner-ups (direct commercial and staffing services) constitute about $5 \%$ of the first jobs and entries respectively. However, among the top categories we also find high-skill industries such as computer programming and other IT activities. 
Figure 7: Distributions (per cent) of industries for first contacts and entry jobs, by calendar year of contact/entry

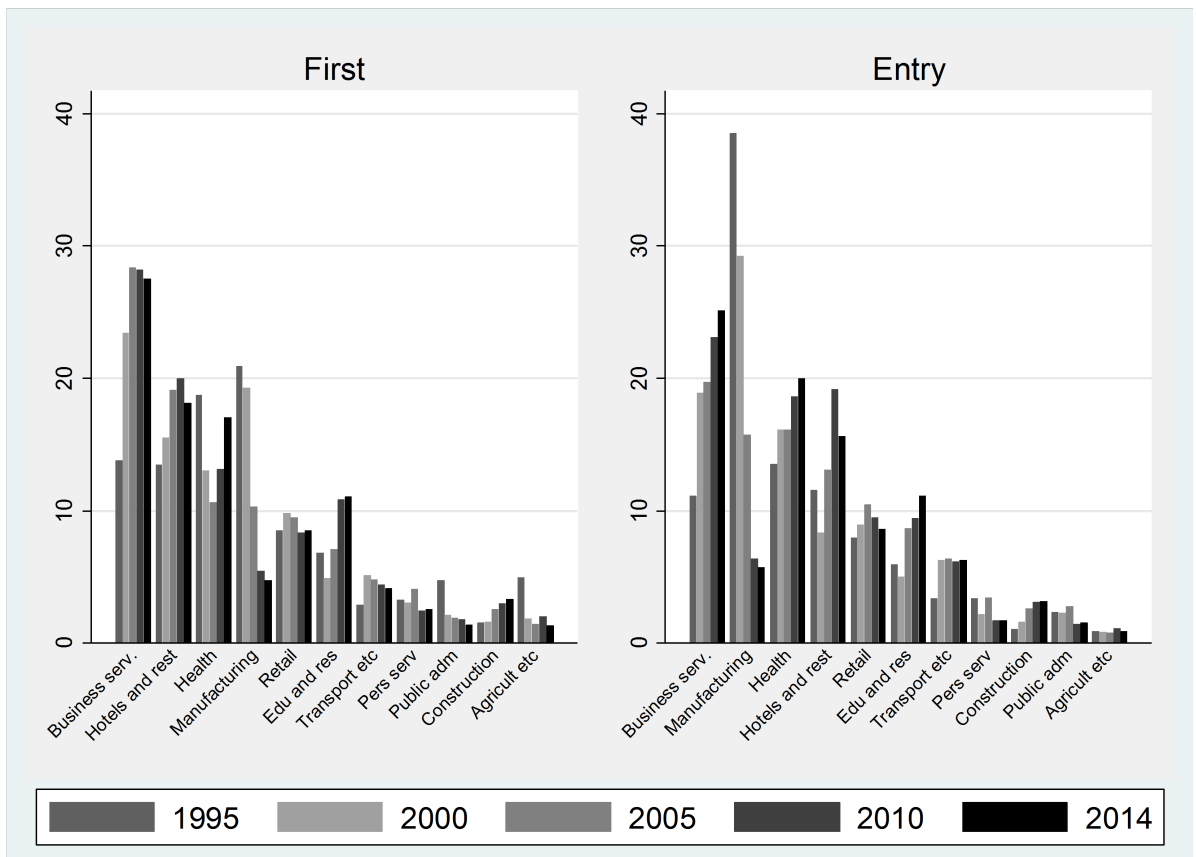

Note: Industries with less than $1 \%$ of entries excluded (Mining and Electricity).

Table 3: Distribution (per cent) of industries for first jobs of immigrants 20-50 years old at immigration year, women and men

Health care

Manufacturing

Transportation and storage

Research and education

Hotels and restaurants

Wholesale and retail trade

Construction

Missing info

Business services

Public administration

Agriculture, forestry and fishing

Personal and cultural services

27.3
9.8
1.8
11.9
9.3
6.4
0.7
8
19.2
2.5
0.6
2.1

$\begin{array}{rr}8.1 & 19.2 \\ 18.1 & -8.3 \\ 8.6 & -6.8 \\ 5 & 6.9 \\ 15.7 & -6.4 \\ 10.3 & -3.9 \\ 4 & -3.3 \\ 4.9 & 3.1 \\ 20.7 & -1.5 \\ 1.4 & 1.1 \\ 1 & -0.4 \\ 2.2 & -0.1\end{array}$




\subsubsection{Firm sizes and earnings levels}

We now turn to briefly characterize the firms where immigrants find their first jobs. Figure 8 below shows the size distributions for the overall (i.e. all workers), first contacts, and entry jobs firms, in the years 2000 and 2014 respectively. Apart from single-person firms, immigrant first contact/entry jobs are disproportionately often found in smaller firms, with less than 20 employees. This pattern has become more accentuated over time, which is in line with e.g. hotels and restaurants becoming a more common port of entry to the Swedish labour market..$^{42}$

Figure 8: Employment distribution over firm sizes 2000 and 2014, total and for immigrants' first jobs
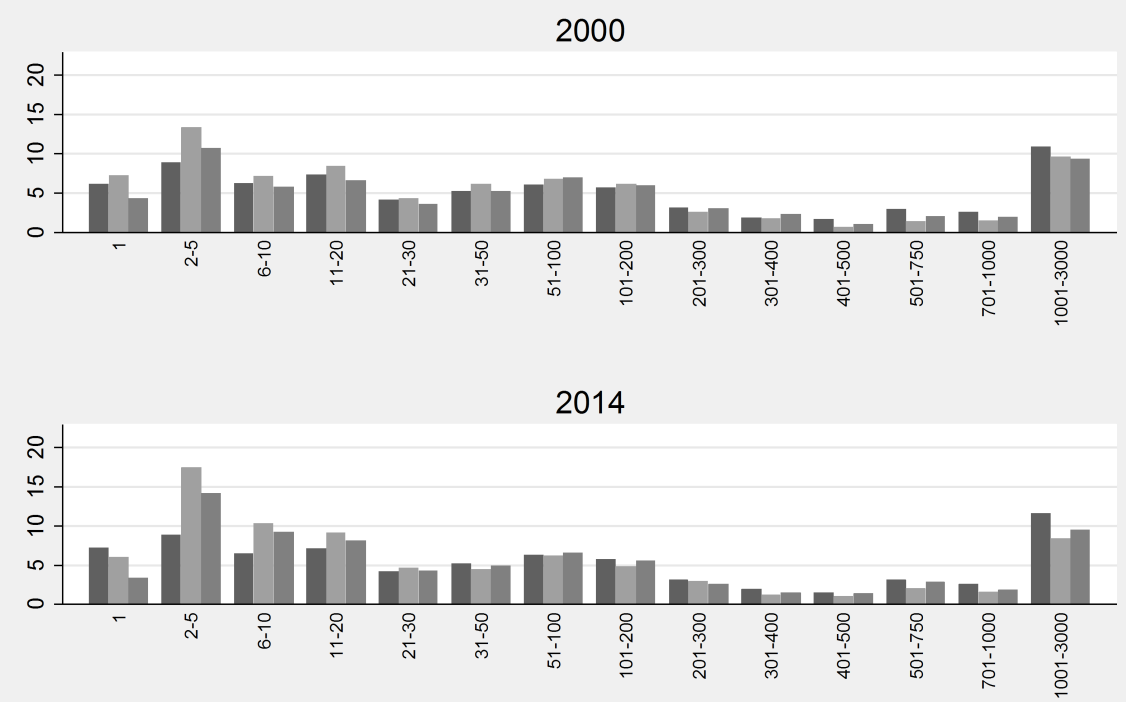

\begin{tabular}{|l|l|}
\hline Overall & First contact \\
\hline
\end{tabular}

${ }^{42} \mathrm{~A} 3000+$ category has been omitted for visibility reasons. The category encompasses about $25 \%$ of the employed and includes a lot of local/regional public sector employment. It decreases its share somewhat over time. 
Figure 9 displays cumulative distributions of the worker-weighted firm average earnings distribution for first contacts made in different years. For example, the graph shows that about of the contacts made in 2005 and 2010 , more than $50 \%$ were in firms below the zoth percentile of average firm earnings encountered by the overall workforce. In other words, these first jobs are often found in low-earner firms. This pattern has also been accentuated in later years; the later cohorts are above earlier ones at the lower part of the distribution. The mirror image is of course an underrepresentation in the upper part of the distribution: around $10 \%$ of the first contacts are with firms above the 7oth percentile of the earnings distribution.

Figure 9: Cumulative distributions of first contacts in (worker-weighted) distribution of average firm earnings

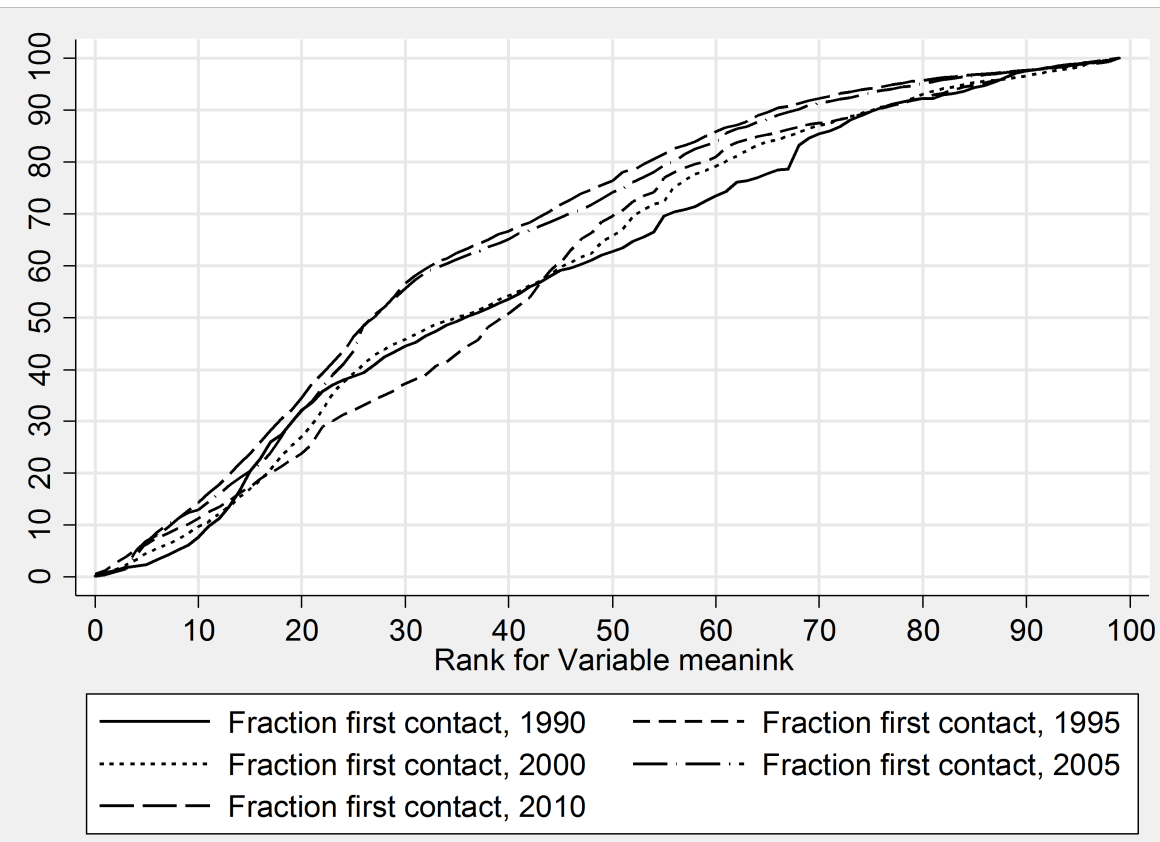




\subsection{Long-term outcomes for selected refugee/migrant groups}

So far, our analysis has to some extent focused on the first contacts and the process to a more stable position in the Swedish labour market. In this section we take a different perspective and follow selected country-of-origin-period-of-arrival groups of migrants coming to Sweden before the mid 1990s. This serves two purposes: receiving a very long-term follow-up period and narrowing the sample to cases where unrest-triggered refugee-related migration strongly dominated the inflow. These criteria in combination with the requirement of having a large enough number of individuals in each group has led us to follow immigrant cohorts from Chile (1973-79), Vietnam (1979-81), Poland (1982-83), Iran (1984-89), the Horn of Africa (1987-94), and Bosnia and Herzegovina (1993-94); see Table A3 for details.

Figure 10 displays the employment rates by number of years since immigration for the respective refugee groups. The most striking feature of the figure is arguably that immigrants from all regions mostly end up with employment rates between 60 and $70 \%$ after some 20 years in Sweden. The employment rate for immigrants from the Horn of Africa even exceeds $70 \%$ after around 25 years since immigration. ${ }^{43}$ This may come as a surprise given that people from this part of the world have a poor average position in the labour market. Migrants from Bosnia and Herzegovina are especially rapid climbers, reaching $70 \%$ employment rate in about 5 years after immigration. For migrants from Chile, Vietnam and Poland we see a steady negative trend from a high level of employment. This may partly reflect that migrants have been seen to leave the labour force at comparatively young ages, but could also be due to composition issues.

${ }^{43}$ All these numbers may be associated with different selection problems. For example, it is not unlikely that the return migration to the source country is more likely to occur among those who have bad labour market outcomes in Sweden. 
Figure 10: Employment and social assistance receipt, immigrants from selected source regions and cohorts by years since immigration
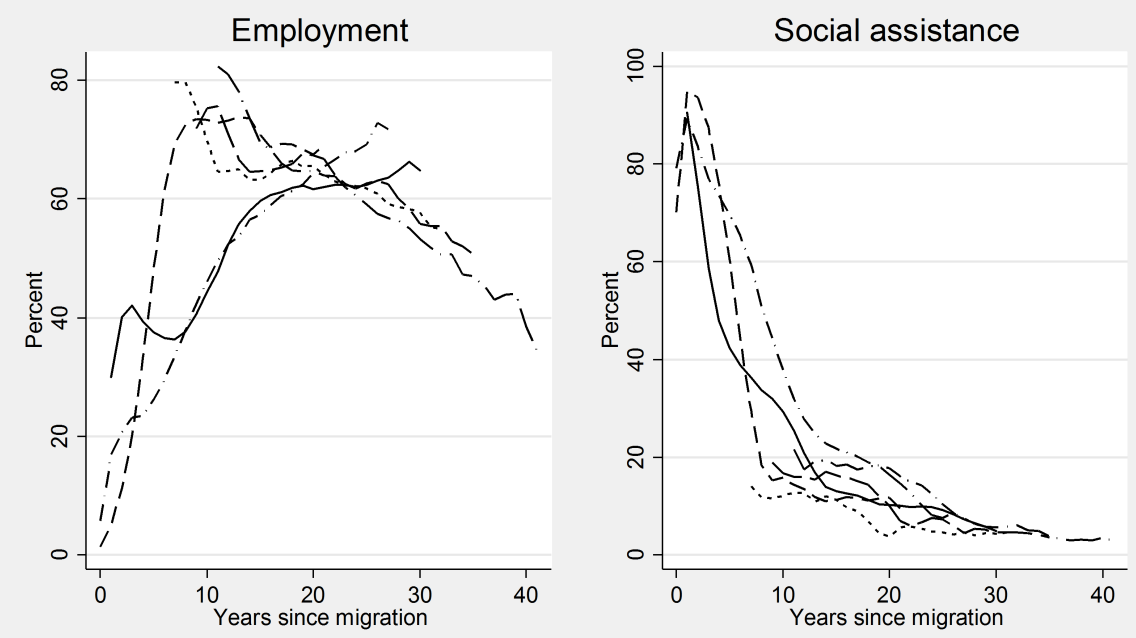

\begin{tabular}{lll}
\hline & Iran, 1984-1989 & ---- Bosnia and Herzegovina, 1993-1994 \\
…...... Poland, 1982-1983 & - - - Chile, 1973-1979 \\
$-\ldots-$ Vietnam, 1979-1981 & $-\ldots-$ - Horn of Africa, 1987-1994
\end{tabular}

Note: Age 20-50 at immigration, censored at age 65 . 
Figure 11: Percentile ranked earnings, immigrants from selected source regions and cohorts by years since immigration
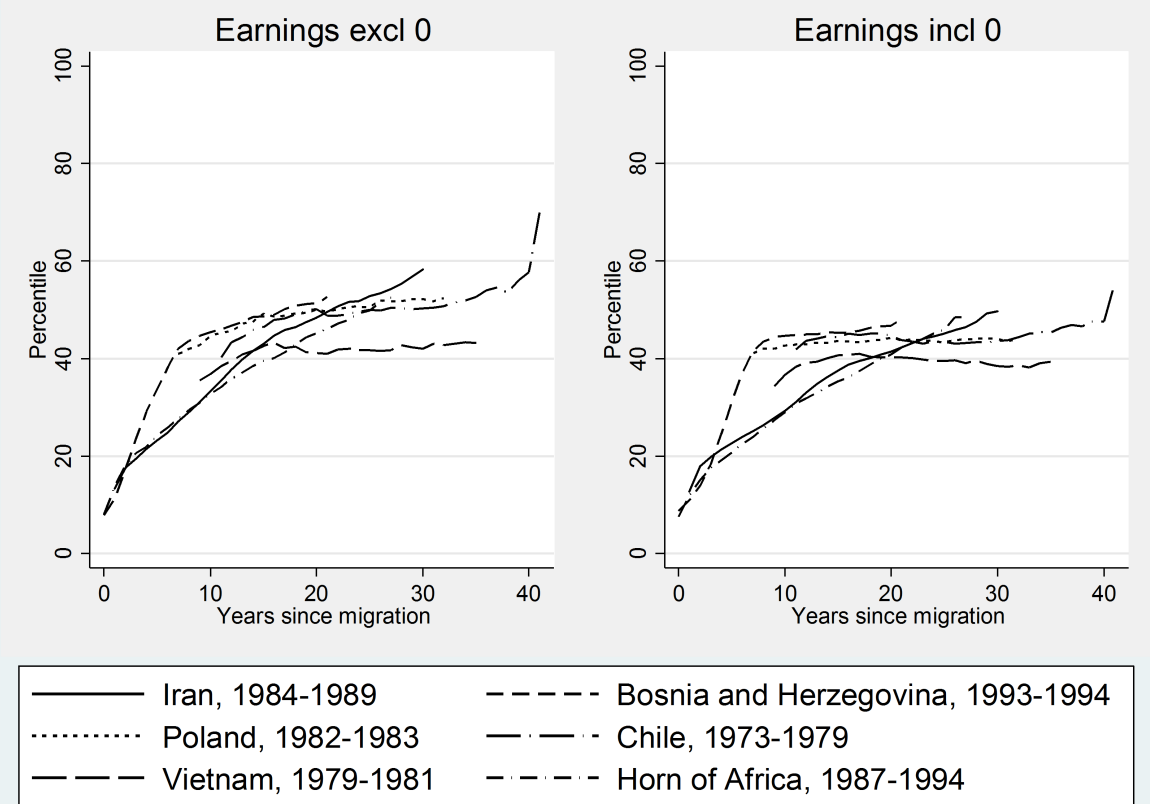

Note: Age 20-50 at immigration, censored at age 65 .

Even though social assistance (at least) historically has been the only available part of the security net for many recently arrived immigrants, it can in a long-term perspective be considered an indicator of poverty or poor position. Most often, households that cannot rely on friends or relatives get income support in the form of social assistance from the municipalities. The right-hand side part of Figure 10 plots social assistance take-up by years since immigration for immigrants from the regions we study. Immigrant households from Iran, the Horn of Africa and from Bosnia and Herzegovina all start their periods in Sweden with social assistance take-ups around 90\%. However, relatively rapidly the numbers start falling. Immigrants from the Horn of Africa is something of a negative outlier in this dimension, but about 25 years after immigration, take-up of this group also goes down below $10 \%$ as for all other groups. 
We have seen that long-run employment rates are reasonably high among immigrants from the regions that we study. Are those jobs also well paid, or do immigrants get access only to part-time, low-paid jobs even in the long run? One way to throw some light on this issue is to investigate where in the overall earnings distribution immigrants end up. Such computations are shown in Figure 11, which plots the average earnings percentile for the groups of immigrants that we study by years since immigration. ${ }^{44}$ The story is not one of immediate success; it takes some 20 years after immigration to reach the median earnings in the overall distribution for immigrants from most countries. ${ }^{45}$ Immigrants from Vietnam end up worst off in terms of income percentiles - the distance to immigrants from the other countries seems to be around 10 percentiles in the long run. Second, immigrants from Bosnia and Herzegovina climb up the income percentiles more rapidly than immigrants from the other countries, although immigrants from Chile and Poland are close behind. Including persons with zero incomes gives a similar picture, although the lower levels in the righthand side graph indicate that also immigrants from these six regions both have lower incomes given that they are working and lower "earner rates" than native Swedes. In fact, this "double penalty" means that immigrants from most regions and most of the time on average remain significantly below the median in the income distribution.

The long-term patterns for employment, social assistance and earnings hint on issues on labour force participation, retirement and use of social insurance that are important but beyond the scope of this paper. The negative trend in employment can partly be due to early retirement, but it is noteworthy that for some groups employment appears to peak after a relatively short time in Sweden. Given that social assistance receipt drops sharply and earnings continue to be relatively low, it would in future work be interesting to study if income is supported through other forms of benefits or pensions.

44 We percentile rank all individuals in the Swedish working age population all years and retrieve the ranks of all immigrants to form average ranks each number of years after immigration.

45 Notice that we, by construction, capture possible effects of both aging and an increased number of years since migration. See also footnote 40 . 


\subsection{Policies, institutions and other factors of importance}

Sweden has for a long time had policies concerning the reception and labour market integration of refugees. Some measures are targeted only at this group, whereas others can be seen as parts of general policies for the unemployed. ${ }^{46}$ Despite these efforts, outcomes remain relatively poor as described and discussed above. But the specific knowledge on which factors and policies improve the chances of labour market integration remains limited also in an international perspective; see e.g. (Butschek \& Walter 2013; Rinne 2012; Kogan 2016; European Parliament 2016; Martín et al 2016). Below we first mention central recent and ongoing policy efforts and then turn to discuss possible factors affecting the labour market prospects of recent migrants.

\subsubsection{What happens and what is done?}

Since December, 2010, when the responsibility of integration policies was moved from the municipalities to the PES, the hub of integration policies in Sweden is the two-year introduction programme at the PES for new recipients of residence permits. The introduction programme has been studied by Andersson Joona et al. (2016), finding a positive impact on employment and earnings. It may though be premature to draw firm conclusions regarding the labour market effects of this rather pervasive reform. Reports from e.g. the National Audit Office (Riksrevisionen, 2014) have documented problems in the implementation of certain aspects of the reform, and relatively slow outflows to work (which, however, has been the case for a long time, as seen above).

The large influx of asylum seekers has also triggered a number of new policies. One such policy is so called fast tracks to employment for newly arrived immigrants. These fast tracks aim at transferring refugees with relevant skills and experiences to occupations where employers face difficulties in finding the right competence. Information on the actual content of the different fast tracks ${ }^{47}$ is scarce, and as yet very few refugees have actually entered them. What seems to be clear is that one fundamental ingredient is validation, and it is also clearly stated that the exact

\footnotetext{
$4^{6}$ See e.g. OECD (2016) for an overview.

47 Some of the existing fast tracks are for engineers with a number of different specialties, teachers, doctors, pharmacists and dentists.
} 
procedures are supposed to be specific to each track and that the social partners (employers and unions) should play an active role.

\subsubsection{Effects of policies ${ }^{48}$}

Policies for the integration of immigrants potentially work on a number of margins. One way to classify these margins is to distinguish between policies affecting supply, demand and matching, respectively. It goes without saying that policies often work through more than one margin, and that any classification scheme is bound to be somewhat arbitrary.

\section{Labour supply}

There are many potential policy margins to affect labour supply. Validation is an important tool to identify skills and lack of skills. Unfortunately, there are no studies available on the effects of the validation efforts that have been undertaken in Sweden. Different ways of competence upgrading are important for labour supply. The types of upgrading vary by the age and background of immigrants.

It is well known that a completed upper secondary education is important for young persons' labour market entry (see, for example, Engdahl \& Forslund, 2016). Hence, one important policy margin is measures to promote schooling success among young immigrants. Results in Engdahl \& Forslund (2016) suggest that this works reasonably well for youth entering Sweden at ages below the start of upper secondary education, whereas youth older than 16 years at arrival rarely finish upper secondary school (also counting adult education).

But education and training also concerns skill acquisition among older immigrants (probably preferably following validation). Appropriate skill acquisition varies between individuals. However, a common need for most is to learn the Swedish language.

Swedish for immigrants ( $s$ fi) has been a part of Swedish integration policies for a long time. There is ample evidence that mastering the host country's language contributes to a "better" job offer distribution. However, research on the effects of sfi is very limited. To be effective, sfi should be something immigrants participate in and which gives participants a good language skills. Historically, a large fraction of

${ }^{48}$ Much of the material presented here draws on the survey in Forslund \& Åslund (2016). 
immigrants has not participated (Kennerberg \& Sibbmark, 2005), and a significant fraction of the participants has not completed the programme (Statskontoret, 2009). Evaluations by the National Audit Office (Riksrevisionen, 2008) and Kennerberg \& Åslund (2010) give no clear-cut conclusions, but possibly suggest that refugee immigrants have benefitted from the programme.

Vocational labour market training programmes organized by the PES (AMU) and adult vocational training programmes (Yrkesvux) as well as adult education organised by the municipalities (Komvux) are three possible ways to upgrade the skills of immigrants.

Komvux has primarily been evaluated in connection with the so called knowledge lift in the 1990s. The results are ambiguous, and effects have not been estimated for immigrants separately. Yrkesvux has never been evaluated but Statskontoret (2012) showed the the Yrkesvux courses often are very similar to AMU courses. Evaluations of AMU may therefore be informative about the effects of Yrkesvux as well. de Luna et al. (2008) estimated the effects of AMU for a number of groups of participants, one of these groups being non-Nordic immigrants. The estimated effects for this group were positive and large; effects for non-Nordic immigrants were comparable with effects for persons with low education and larger than the estimated effects for any other group.

Work practice arranged by the PES could be another way to acquire skills or valuable networks to facilitate integration. The results in Forslund et al. (2013), however, indicate that the results for non-Nordic immigrants are about average and significantly inferior to vocational training programmes for the group.

There is only limited knowledge about the effects of tertiary education, including tertiary vocational education, on immigrants' labour market outcomes. Rooth \& Åslund (2006) found that immigrants have returns to education taken in the source country and (especially) taken in Sweden. Katz \& Österberg (2013) estimated lower returns to higher education for immigrants arriving to Sweden as kids compared to the returns for native Swedes. Lind \& Westerberg (2015) found that immigrants experienced greater earnings gains after tertiary vocational education than other groups.

But adequate skills are not enough. There must be proper incentives for job search. There is a vast literature on incentive problems created by various social security systems, designed to replace income losses or alleviate poverty. ${ }^{49}$ This may especially

49 More generally, all systems that affect the net gains from working compared to non-working can be expected to have an impact on labour supply. The design of income tax systems is an obvious example. 
important for immigrants: Andrén \& Andrén (2013) found that state dependence (so that benefit reception creates future benefit reception) is higher among immigrants than among native Swedes.

A number of reforms designed to create incentives for labour supply have been undertaken in tax systems, unemployment insurance, sickness insurance and social assistance. However, the design of the reforms has made them difficult to evaluate and there is basically no well identified evidence on how these reforms have affected the labour supply of immigrants. Nevertheless, most reforms have been designed to increase the gains from working most for low-income earners, so we would expect a positive impact on the labour supply of recently arrived immigrants. We do not, however, have any good ground for an opinion about the size of any such effects.

As part of the introduction programme, introduction guides were introduced in December 2010. The system entailed that optional activities could be offered newly arrived immigrants in the introduction programme. The aim was that the guide should give the newly arrived immigrants support to facilitate integration. The system does not seem to have worked well (Riksrevisionen, 2014, Sibbmark et al 2016) and has been abandoned.

\section{The demand for immigrant labour}

A standard explanation to the gradual increase in earnings and employment probabilities seen among immigrants to many countries is that the initial lack of country-specific human capital is removed through experience and learning in the host country. Human capital in a broad sense can be accumulated and will typically increase with the duration of the stay. Investments can be formal (e.g. acquiring supplementary education or language training) or more informal capturing softer factors (social codes, style of speech etc). But since this process takes time, there is an argument for measures trying to increase effective demand through lower hiring costs for the first years if one believes that productivity for a sufficiently large fraction of the group is so low that it falls short of existing minimum wages.

One policy option to level the playing field is to use wage subsidies. Targeted wage subsidies are, according to available evaluations, normally effective (Calmfors et al., 2004; Card et al., 2010; Forslund \& Vikström, 2011; Liljeberg et al., 2012; Sjögren \& Vikström, 2015). However, a very generous subsidy programme targeted at newly arrived immigrants has had a very low take-up, so using wage subsidies targeted at immigrants has not proved to be effective in this sense. It can be considered a riddle 
why employers have not been more interested in hiring people at, say, $20-40 \%$ of the regular wage. Explanations proposed in previous work include complicated systems and supplementary requirements, and an unwillingness to approach and depend on authorities (Riksrevisionen, 2015). But still, considering the cost reductions involved, there seems to be room also for other explanations, such as poor matching, lack of contacts and discrimination (see discussion below).

An alternative but closely related route is of course to (somehow) lower regular wages. In a system like the Swedish one with collectively bargained entry and minimum wages, this is not a direct policy tool. Nevertheless, substantial efforts have been made to find solutions targeting e.g. recent migrants. Even though the basic mechanisms should be similar as for wage subsidies, unions appear more concerned that lower wages for some groups would create a downward pressure on the overall wage structure. There is some evidence that effects are spread to workers not directly affected (see e.g. Forslund et al., 2014; David et al. 2016; Lopresti \& Mumford 2016), but it is hard to tell how big the effects of e.g. lower wages for migrants with less than three years of residence would be.

Given that there are concerns regarding negative consequences, it is highly relevant to quantify the expected gains: how large an impact on transitions to employment should one expect? There is a large literature on the employment effects of minimum wages. A vast majority of these studies refer to systems where minimum wages are determined by law (many studies refer to the U.S.). It is not evident that results from these studies are directly applicable to the Swedish context, where minimum wages are determined by collective agreements. One important difference, with a possible bearing on the interpretation of the results, is that legally determined minimum wages stipulate one common minimum wage for the whole economy, whereas collective agreements are struck at the sectoral level. One implication of this is that the "bite" of the minimum wage can be expected to be harder in Sweden than in countries with legally determined minimum wages, because a single minimum wage cannot be chosen too high if low-productivity jobs are to survive. If estimated effects depend on the bite of the minimum wage, which empirical evidence seems to suggest, then it is possible that many studies underestimate the effects of minimum wages in Sweden.

Our reading of the evidence is that lower minimum wages can be expected to be associated with higher employment, but that elasticities are moderate and, thus, that the effects also normally are moderate. The few studies there are of Swedish minimum 
wages (Forslund et al., 2014; Skedinger, 2006, 2011; Konjunkturinstitutet, 2010) often, but not unambiguously, suggest negative but moderate employment impacts of higher minimum wages. All in all, a possible interpretation of these results is that the wage cost cuts necessary to by themselves give rise to any substantial employment impact for groups with a low productivity would be so large that they are unlikely to occur. However, this does not mean that lowering the wage costs for newly arrived immigrants would produce no impact at all. It should also be noted that certain possible effects of minimum-wage cuts are extremely hard to capture in empirical studies, namely effects like the opening-up of new low-wage sectors. To the extent that such effects do occur, existing studies would tend to underestimate the impact of minimum wages on employment.

A possible reason for limited impacts of lower hiring costs is discrimination; i.e. employers are for some reason not indifferent between job seekers of varying characteristics at a given wage. Empirically, both trials using anonymous or internet based job applications (Edin \& Lagerström, 2006; Eriksson \& Lagerström, 2012; Åslund \& Skans, 2012), so called correspondence studies (Carlsson \& Rooth 2007; Bursell 2014) and a stated preference study (Eriksson et al., 2012) suggest that immigrants are discriminated against in the Swedish labour market..$^{\circ}$

Discrimination is a complex and much debated concept, and we will not get into the theoretical details here (ranging from classical taste-based models to broader structural perspectives). Recent research has also pointed to the importance of implicit and unconscious attitudes as an explanation to discriminatory behaviour (Rooth, 2010). An important difference between a native and a recently immigrated person with the same competence is that employers probably are more uncertain about qualifications acquired abroad, even with well functioning validation. This means that there always is a risk for statistical discrimination against recently arrived immigrants, i.e. risk-averse employers prefer what they consider safe candidates. Empirically, it is very hard to separate the mechanisms from each other.

If uncertainty about qualifications is a factor of importance, employment protection legislation (EPL) could be a particular problem. In addition to generally protecting the jobs of the already employed and thus potentially impeding the entry for those without jobs, it may then also make employers less willing to hire "high-risk"

50 Åslund, Hensvik \& Skans (2014) also showed that the background of the manager has an impact on who is recruited immigrant managers hire immigrants more often than do native managers. 
individuals. One such group is arguably the newly arrived immigrants. Swedish employment protection is complex. First, there are very few obstacles for employers to use fixed-term contracts, including the use of temp agencies. Second, Swedish employers can freely downsize the workforce by appealing to redundancy. Third, on the other hand, by default downsizing should be executed by last in, first out (LIFO) rules for employees with open-ended contracts. Fourth, LIFO can be replaced by other arrangements according to collective agreements between unions and employers.

So how strict is Swedish employment protection? Looking at OECD characterisations, Swedish EPL is close to the OECD average. The most prominent feature according to $O E C D$, however, is the very large difference between the rules for fixed-term and open-ended contracts. This reflects an assessment that EPL for openended contracts in Sweden is rather strict. A possible objection to this assessment is the fact that LIFO can be replaced by other arrangements by collective agreements. Probably this means that the strictness varies with the character of labour relations in different sectors and firms. Overall, in our judgement, it is likely that the integration of immigrants into the Swedish labour market is hampered somewhat by EPL, but EPL is not likely to be a major obstacle to labour market entry in Sweden.

\section{Matching}

Given workers with sufficient and attractive skills, and employers willing to hire, matching is another important margin affecting labour market outcomes, at the individual level as well in the aggregate.

A growing literature shows the importance of informal contacts and networks in the labor market (see e.g. Dustmann et al. 2016; Kramarz and Skans 2014). ${ }^{11}$ There are good reasons to believe that recent migrants often lack at least some of the contacts that help in finding employment (e.g. Swedish employers). In this sense, there is argument for policy to bridge this gap; become/create the network for people with poor networks. There is evidence that such measures (typically in combination with subsidized employment) have had positive effects for immigrants in the Swedish labor market (Joona \& Nekby 2012; Åslund \& Johansson 2011; Liljeberg \& Lundin 2010).

These evaluations all consider situations where the PES agents had much more time to build and maintain employer contacts. The treatment was quite intense in that

${ }^{51} \mathrm{~A}$ closely related literature studies how peer exposure affects labour market outcomes among migrants; see e.g. Damm (2009, 2014) and Edin et al. (2003). 
the agent only had a small number of clients in parallel, especially considering the workload of at least 100 job seekers for a typical case worker. The total number of job seekers involved was very limited compared to the number of recent migrants who have not yet found a foot in the Swedish labor market. One can of course question whether activities can be scaled up with maintained quality. But considering the substantial costs of people remaining on welfare benefits instead of working (and paying taxes), rather high costs could be defended if the treatment improves the longterm labor market position of the individual.

Given the patterns seen for recent migrants in the Swedish labor market, there are good reasons to believe that many people are never even considered for job opportunities that are there. In this sense, matching initiatives increasing the exposure between workers and potential employers seem reasonable.

\subsection{Concluding remarks}

The paper describes the short- and long-term labour market situations for nonWestern, typically refugee-related, immigrants to Sweden during the last decades. Using rich data on individuals, firms and labour market outcomes, we have tried to characterize the first contacts with the labour market, the route to entry and the ensuing labour market position. Our main analysis considers people arriving in the 1990-2014 period, but we have also studied long-term indicators for selected groups of earlier migrants.

The most striking feature is perhaps the remarkable stability of the aggregated patterns. Business cycle variations encountered at arrival may affect progress in the early years, and there are substantial differences across countries of origin. But the overall picture is that the process of labour market integration has been very similar over a long period of time. Is this good or bad? Good, perhaps, in the light of the current situation with many people waiting for or having just received asylum; entry patterns do not seem to be strongly connected to variations in immigration levels. But, arguably, bad considering that the process is slow and success limited, at least in the short run. It takes a long time for people to find a place in the Swedish labour market, and even in the long run many migrants do not reach parity with native workers.

We have tried to go beyond updating the well-known patterns of employment and earnings integration/assimilation. To this end we have documented durations and 
numbers of jobs involved in the entry process. Even though many people spend considerable times from the first contact to a more stable position, it seems that the first contact with an employer often serves as the door to the labour market. Compared to e.g. youth finding their way, immigrants do not exhibit many employer contacts on their way to a job generating a more substantial annual income. Over time, service industries of different kinds have become a more important port of entry for migrants. We also see an increasing representation of immigrants in small and low-wage firms.

Are stable but poor outcomes unavoidable in the future? Our discussion of policy experiences identifies several margins, measures and institutions linked to the labour market integration of refugees and other migrants. But it is hard to point to one single factor that could change things in a major way. On the other hand, this is rarely the case with complex social challenges concerning a wide and very heterogeneous population. However, poor outcomes also mean potential to do better, and our data do contain examples of refugees arriving under less than beneficial circumstances, but progressing significantly.

\section{References}

Andersson Joona, P., Lanninger, A. and Sundström, M. (2016), Reforming the Integration of Refugees: The Swedish Experience, IZA discussion paper 10307.

Andrén, T. and Andrén, D. (2013), Never give up? The persistence of welfare participation in Sweden, IZA Journal of European Labor Studies, 2(1), 1-21. https://doi.org/10.1186/2193-90122-1

Åslund, O., Hensvik, L. and Skans, O. N. (2014), Seeking similarity: How immigrants and natives manage in the labor market, Journal of Labor Economics, 32(3), 405-441. https://doi.org/10.1086/674985

Åslund, O. and Rooth, D-O. (2007), Do when and where matter? Initial labor market conditions and immigrant earnings, Economic Journal 117, 422-448. https://doi.org/10.1111/j.14680297.2007.02024.x

Åslund, O. and Johansson, P. (2011), Virtues of SIN - Can Intensified Public Efforts Help Disadvantaged Immigrants? Evaluation review, 35(4), 399-427. https://doi.org/10.1177/0193841X11419282

Åslund, O. and Skans, O. N. (2012), Do anonymous job application procedures level the playing field?, Industrial and Labor Relations Review 65(1), 82-107. https://doi.org/10.1177/001979391206500105

Barth, E., Bratsberg, B. and Raaum, O. (2012), Immigrant wage profiles within and between establishments, Labour Economics 19(4), 541-556. https://doi.org/10.1016/j.labeco.2012.05.009 
Bursell, M. (2014), The Multiple Burdens of Foreign-Named Men - Evidence from a Field Experiment on Gendered Ethnic Hiring Discrimination in Sweden, European Sociological Review. https://doi.org/10.1093/esr/jcu047

Butschek, S. and Walter, T. (2013), What Active Labour Market Programmes Work for Immigrants in Europe? A Meta-Analysis of the Evaluation Literature, A Meta-Analysis of the Evaluation Literature (August 21, 2013), ZEW-Centre for European Economic Research Discussion Paper, (13-056).

Calmfors, L., Forslund, A. and Hemström, M. (2004), The effects of active labor-market policies in Sweden: What is the evidence?", in J Agell, M Keen and J Weichenrieder (eds), Labor Market Institutions and Public Regulation, MIT Press.

Card, D., Kluve, J., and Weber, A. (2010), Active Labour Market Policy Evaluations: A MetaAnalysis, The Economic Journal, 120(548), F452-F477. https://doi.org/10.1111/j.14680297.2010.02387.x

Carlsson, M. and Rooth, D-O. (2007), Evidence of ethnic discrimination in the Swedish labor market using experimental data, Labour Economics, 14(4), 716-729.

https://doi.org/10.1016/j.labeco.2007.05.001

Damm, A. P. (2009), Ethnic enclaves and immigrant labor market outcomes: Quasiexperimental evidence, Journal of Labor Economics, 27(2), 281-314. https://doi.org/10.1086/599336

Damm, A. P. (2014), Neighborhood quality and labor market outcomes: Evidence from quasirandom neighborhood assignment of immigrants, Journal of Urban Economics, 79, 139-166. https://doi.org/10.1016/j.jue.2013.08.004

David, H., Manning, A., and Smith, C. L. (2016), The contribution of the minimum wage to US wage inequality over three decades: a reassessment, American Economic Journal: Applied Economics, 8(1), 58-99.

De Luna X., Forslund A. and Liljeberg, L. (2008), Effekter av yrkesinriktad arbetsmarknadsutbildning för deltagare under perioden 2002-04, Rapport 2008:1, IFAU.

Dustmann, C., Glitz, A., Schönberg, U., and Brücker, H. (2016), Referral-based job search networks, The Review of Economic Studies, 83(2), 514-546. https://doi.org/10.1093/restud/rdv045

Edin, P. A., Fredriksson, P., and Åslund, O. (2003), Ethnic enclaves and the economic success of immigrants-Evidence from a natural experiment, The quarterly journal of economics, 118(1), 329-357. https://doi.org/10.1162/00335530360535225

Edin, P-A. and Lagerström, J. (2006), Blind dates: quasi-experimental evidence on discrimination, Working Paper 2006:4, IFAU.

Engdahl, M. and Forslund, A. (2016), En förlorad generation? Om ungas etablering på arbetsmarknaden, Rapport 2016:1, IFAU.

Erikson, R., Skans O. N., Sjögren, A. and Åslund, O. (2007), Ungdomars och invandrades inträde på arbetsmarknaden 1985-2003, Rapport 2007:18, IFAU.

Eriksson, S. and Lagerström, J. (2012), Detecting discrimination in the hiring process: evidence from an Internet-based search channel", Empirical Economics, 43(2), 537-563.

https://doi.org/10.1007/s00181-011-0496-6 
Eriksson, S., Johansson, P. and Langenskiöld, S. (2012), What is the right profile for getting a job? A stated choice experiment of the recruitment process, Working Paper 2012:3, IFAU.

European Parliament (2016) Labour Market Integration of Refugees: Strategies and good practices.

Forslund, A., Hensvik, L., Skans, O. N., Westerberg, A. and Eliasson, T. (2014), Avtalslöner, löner och sysselsättning, Rapport 2014:8, IFAU.

Forslund A., Liljeberg, L. and von Trott Zu Solz, L. (2013), Job practice: an evaluation and a comparison with vocational labour market training programmes, Working paper 2013:6, IFAU.

Forslund A. and Vikström, J. (2011), Arbetsmarknadspolitikens effekter på sysselsättning och arbetslöshet - en översikt, Rapport 2011:7, IFAU.

Forslund, A. and Åslund, O. (2016), Migration, demografi, arbetsmarknad och ekonomi, Underlagsrapport från analysgruppen Arbetet i framtiden.

Joona, P. A., and Nekby, L. (2012). Intensive Coaching of New Immigrants: An Evaluation Based on Random Program Assignment, The Scandinavian Journal of Economics, 114(2), 575-60o. https://doi.org/10.1111/j.1467-9442.2011.01692.x

Katz, K. and Österberg, T. (2013), Wages of childhood immigrants in Sweden - education, returns to education and overeducation, Working paper 2013:8, IFAU.

Kennerberg, L. and Sibbmark, K. (2005), Vilka deltar i svenska för invandrare, Rapport 2005:13, IFAU, Uppsala.

Kennerberg, L. and Åslund, O. (2010), Sfi och arbetsmarknaden, Rapport 2010:10, IFAU, Uppsala.

Kogan, I. (2016), Integration Policies and Immigrants' Labor Market Outcomes in Europe, Sociological Science, 3, 335-358. https://doi.org/10.15195/v3.a16

Konjunkturinstitutet (2010), Lönebildningsrapporten 2010, Konjunkturinstitutet, Stockholm.

Kramarz, F., and Skans, O. N. (2014), When strong ties are strong: Networks and youth labour market entry, The Review of Economic Studies, 81(3), 1164-1200.

https://doi.org/10.1093/restud/rdto49

Liljeberg, L., and Lundin, M. (2010), Jobbnätet ger jobb: effekter av intensifierade arbetsförmedlingsinsatser för att bryta långtidsarbetslöshet, Rapport 2010:2, IFAU.

Liljeberg, L., Sjögren, A. and Vikström, J. (2012), Leder nystartsjobben till högre sysselsättning? Rapport 2012:6, IFAU.

Lind, P. and Westerberg, A. (2015), Yrkeshögskolan - vilka söker, vem tar examen och hur går det sedan? Rapport 2015:12, IFAU.

Lopresti, J. W., and Mumford, K. J. (2016), Who Benefits from a Minimum Wage Increase?, ILR Review, 0019793916653595 .

Martín I., Arcarons, A; Aumüller, J., Bevelander, P., Emilsson, H., Kalantaryan, S., Maciver, A., Mara, I., Scalettaris, G., Venturini, A., Vidovic, H., Van Der Welle, I., Windisch, M., Wolffberg, R., Zorlu, A. (2016), From refugees to workers: mapping labour market integration support measures for asylum-seekers and refugees in EU member states. Volume II : Literature review and country case studies.

Nilsson, Å. (2004), Efterkrigstidens invandring och utvandring. Statistiska centralbyrån. 
OECD (2016), Working together, Skills and labour market integration of immigrants and their children in Sweden. OECD, Paris. https://doi.org/10.1787/9789264257382-en

Riksrevisionen (2008), Svenskundervisning för invandrare (sfi) - En verksamhet med okända effekter. Rapport 2008:13, Riksrevisionen, Stockholm.

Riksrevisionen (2014) Etableringslotsar - fungerar länken mellan individen och arbetsmarknaden?, RiR 2014:14.

Riksrevisionen (2015) Nyanländas etablering - är statens insatser effektiva?, RiR 2015:17.

Rinne, U. (2012), The evaluation of immigration policies (No. 6369), Discussion Paper series, Forschungsinstitut zur Zukunft der Arbeit (IZA).

Rooth, D. O. (2010), Automatic associations and discrimination in hiring: Real world evidence, Labour Economics, 17(3), 523-534. https://doi.org/10.1016/j.labeco.2009.04.005

Rooth, D-O. and Åslund, O. (2006), Utbildning och kunskaper i svenska. Framgångsfaktorer för invandrade? SNS Förlag.

Sibbmark, K., Söderström, M. and Åslund, O. (2016), Marknadsmekanismer i teori och praktikerfarenheter från etableringslotsarna, Rapport 2016:19, IFAU.

Sjögren, A. and Vikström, J. (2015), How long and how much? Learning about the design of wage subsidies from policy changes and discontinuities, Labour Economics 34, 127-137. https://doi.org/10.1016/j.labec0.2015.03.009

Skedinger, P. (2006), Minimum Wages and Employment in Swedish Hotels and Restaurants, Labour Economics, 13: 259-90. https://doi.org/10.1016/j.labeco.2004.07.002

Statskontoret (2009), Sfi - resultat, genomförande och lärarkompetens. En utvärdering av svenska för invandrare, Rapport 2009:2, Statskontoret, Stockholm.

Statskontoret (2012), Kostnader för arbetsmarknadsutbildning och yrkesvux - en jämförelse, 2012:28.

\section{Appendix}

\section{Data and restrictions}

We use data from the IFAU database for the years 1985-2014. The database compiles anonymised individual registers, mainly from Statistics Sweden but also from other sources (including the Public Employment Service). Our study population in the main analysis consists of all first time immigrants to Sweden 1990-2014, born in the countries listed in Table $A 1$, age 20-50 at immigration. The restrictions on country of birth are intended to capture primarily refugee related immigration. We also require that the immigrant must stay in Sweden for at least two years after immigration. 


\section{Outcome variable}

Earnings

First contact/job

Entry

Employment

Earnings percentile

Social assistance take up

Social assistance receipt

Registered at PES

Days at PES

Workplace characteristics

\section{Description}

Annual income from work, including self-employment, SEK.

Ever had positive earnings.

Ever had more than half the median earnings of 45 year-olds in a given year.

Employed in November (Statistics Sweden's definition).

Percentile rank of earnings in overall earnings distribution age 20-64.

Social assistance $>0$ in a given year.

Social assistance received in a given year (individualized, SEK).

Registered in open unemployment or labor market programs.

Number of days registered in I given year.

In case of multiple employers in a given year, the one providing the highest earnings is defined as the workplace. An individual can thus not have more than one workplace each year. 


\section{Table A1: Countries included in the main analysis}

\section{Region Countries included}

Eastern Europe

Latin America

Middle East

Africa

Asia
Bosnia-Herzegovina, Former Yugoslavia (Croatia, Yugoslavia, Macedonia, Slovenia), Albania, Armenia, Azerbaijan, Bulgaria, Georgia, Kazakhstan, Moldova, Romania, Russia, Ukraine, Belarus.

Antigua and Baruda, the Bahamas, Barbados, Belize, Costa Rica, Cuba, Dominican Rep, El Salvador, Grenada, Guatemala, Haiti, Honduras, Jamaica, Mexico, Nicaragua, Panama, St. Lucia, St. Vincent, St. Dig and Nevis and Anguil, Trinidad and Tobago, Argentina, Bolivia, Brazil, Colombia, Ecuador, Guyana, Paraguay, Peru, Suriname, Uruguay, Venezuela.

Lebanon, Syria, Morocco, Tunisia, Egypt, Algeria, Israel, the Gaza area, Palestine, Jordan, South Yemen, Yemen, the United Arab Emirates, Kuwait, Bahrain, Qatar, Saudi Arabia, Cyprus, Iran, Iraq, Turkey.

Djibouti, Eritrea, Ethiopia, Somalia, Sudan, Libya, Angola, Egypt, Benin, Botswana, Burkina Faso, Burundi, Central African Republic, Comoros, Equatorial Guinea, Ivory Coast, Gabon, Gambia, Ghana, Guinea, Guinea Bissau, Cameroon, Cape Verde, Kenya, Congo, Lesotho, Liberia, Madagascar, Malawi, Mali, Mauritania, Mauritius, Mozambique, Namibia, Niger, Nigeria, Rwanda, Sao Tome and Pr, Senegal, Seychelles, Sierra Leone, Swaziland, South Africa, Tanzania, Togo, Uganda, Zaire, Zambia, Zanzibar, Zimbabwe.

Kyrgyzstan, Tajikistan, Turkmenistan, Uzbekistan, Myanmar, the Philippines, Indonesia, Laos, Malay Federation, Singapore, Thailand, Vietnam, Afghanistan, Bangladesh, Bhutan, Brunei, India, Kampuchea, Maldives, Mongolia, Nepal, Oman, Pakistan, Sikkim, Sri Lanka. 
Table A2: Description of baseline and supplementary samples

\begin{tabular}{|c|c|c|c|c|c|c|c|}
\hline \multirow[b]{2}{*}{ Sample } & \multicolumn{3}{|c|}{ At immigration } & \multicolumn{4}{|c|}{2014} \\
\hline & $\mathbf{N}$ & $\begin{array}{r}\text { Mean } \\
\text { age }\end{array}$ & $\begin{array}{l}\text { Men, } \\
\text { share }\end{array}$ & $\mathbf{N}$ & $\begin{array}{r}\text { Compul } \\
\text { sory } \\
\text { edu. }\end{array}$ & $\begin{array}{r}\text { Upper } \\
\text { sec. } \\
\text { edu. }\end{array}$ & $\begin{array}{r}\text { Tertiary } \\
\text { edu. }\end{array}$ \\
\hline \multicolumn{8}{|l|}{ Baseline sample } \\
\hline Age $20-50$ at immi., 1990-2014 & 571,313 & 31.0 & 50.3 & 488,187 & 21.8 & 25.1 & 32.6 \\
\hline Cohort 1990 & 14,811 & 30.4 & 52.8 & 10,932 & 23.3 & 28.2 & 21.8 \\
\hline Cohort 1995 & 10,773 & 31.1 & 44.6 & 8,664 & 21.0 & 33.4 & 24.6 \\
\hline Cohort 2000 & 14,127 & 31.0 & 45.4 & 11,558 & 21.4 & $25 \cdot 3$ & 33.7 \\
\hline Cohort 2005 & 19,023 & 30.3 & $49 \cdot 3$ & 14,902 & 19.4 & 24.4 & 32.3 \\
\hline Cohort 2010 & 34,866 & 30.2 & 53.1 & 30,335 & 22.4 & 19.4 & 37.9 \\
\hline \multicolumn{8}{|l|}{ Sample used in section 4.7} \\
\hline Iran, 1984-1989 & 20,523 & 29.6 & 60.9 & 15,720 & 7.6 & 35.2 & 33.7 \\
\hline Bosnia and Herz., 1993-1994 & 22,908 & 32.8 & 51.6 & 20,775 & $13 \cdot 3$ & 50.7 & 26.0 \\
\hline Poland, $1982-1983$ & 3,419 & 31.8 & 55.6 & 2,716 & 6.1 & 41.6 & 31.4 \\
\hline Chile, $1973-1979$ & 3,002 & 27.9 & 56.6 & 1,931 & 10.2 & 31.3 & 22.6 \\
\hline Vietnam, 1979-1981 & 1,910 & 29.1 & 61.3 & 1,497 & 39.0 & 31.3 & 7.7 \\
\hline Horn of Africa, 1987-1994 & 11,114 & 31.4 & 48.0 & 7,734 & 19.0 & 34.9 & 14.7 \\
\hline
\end{tabular}

Note: Horn of Africa includes (Djibouti, Eritrea, Ethiopia, Somalia, and Sudan). The category for Vietnam also includes other countries (Burma, Indonesia, Laos, Malaysia, the Philippines, Singapore and Thailand); immigration from these countries was very small in the years considered. 
Figure A1: Adjusted (age, gender, calendar year) employment differentials, by years since migration

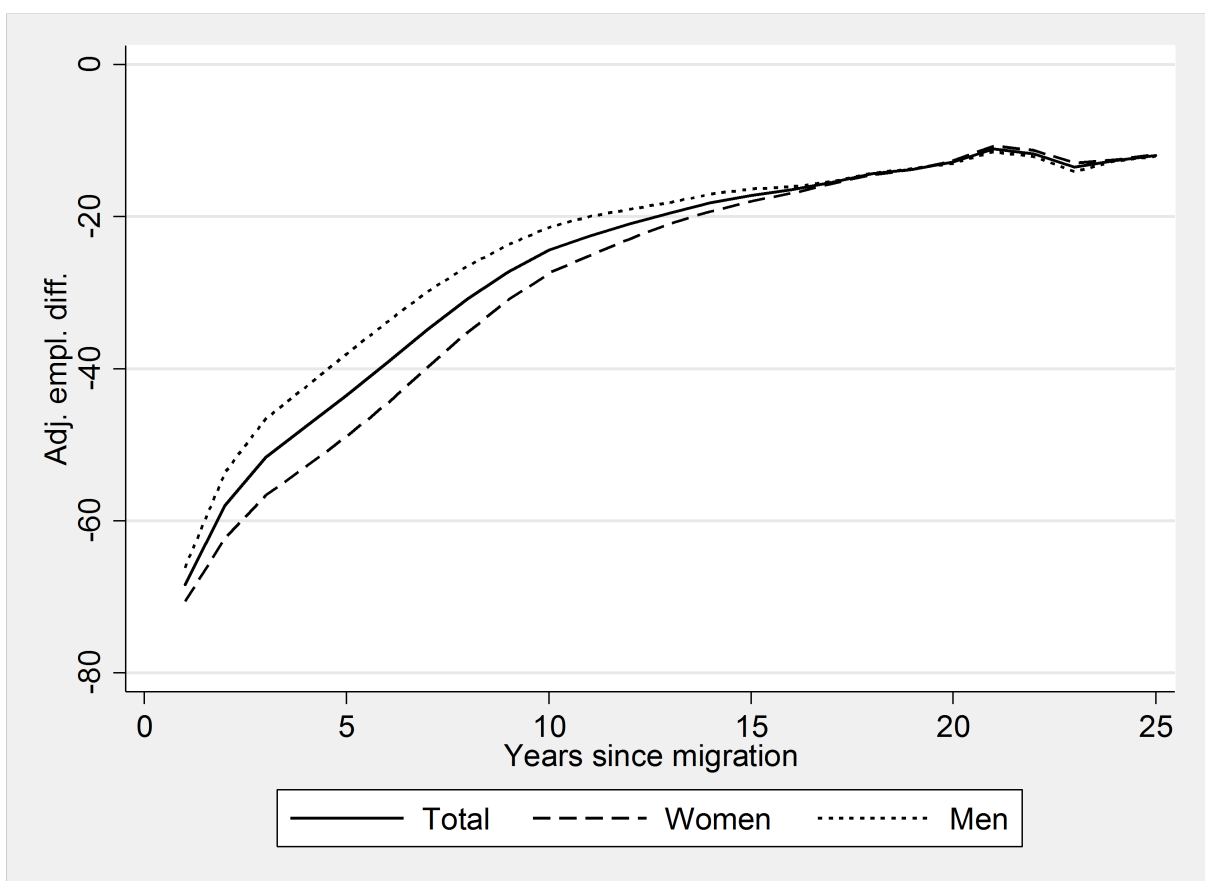

Note: See Sarvimäki (this volume) for a description of the calculations. 


\section{The School Achievements of Refugee Children: Lessons from Sweden ${ }^{2}$}

Hans Grönqvist, 53 Susan Niknami54

\section{Abstract}

Refugee migration has been a major source of immigration to Sweden since the 1980 . This experience stands in contrast to that of many other countries in the OECD. As a result, the share of refugee pupils in school is relatively large in Sweden. Due to the historically small refugee populations in other countries and a lack of data that permits researchers to separate refugees from other types of immigrants little is known about the performance of refugee children in school. This paper documents the compulsory school achievements among refugee pupils since the late 1990 and finds that refugees on average perform significantly worse than other students. Controlling for parental socioeconomic background, however, substantially reduces the differences in school performance between refugees and other students. While school sorting only explains a small (albeit non-trivial) part of the gap, neighborhood of residence account for a considerable portion of the divide. In fact, controlling for parental background and neighborhood effects simultaneously almost eliminates the gap. While we cannot rule out the possibility that our results might be contaminated by unobserved factors, the

\footnotetext{
52 We are grateful to Olof Åslund and Anna Piil Damm (eds.), Riikka Savolainen, referees and participants at the NEPR conference in Oslo on "Labour Market Integration in the Nordic Countries" for comments and suggestions. This study is an extension of work that the authors have done for the Expert Group on Public Economics (ESO) at the Swedish Ministry of Finance (see Grönqvist and Niknami, 2017).

53 Department of Economics, Uppsala University and IFAU, hans.gronqvist@nek.uu.se

54 SOFI, Stockholm University, susan.niknami@sofi.su.se
} 
results are consistent with the notion that improving the general socioeconomic situation of refugees should be of major importance in improving the school achievements of refugee students.

- Keywords: Immigration; Refugee; Student performance.

- JEL codes: $\mathrm{J}_{15}$; 120.

\subsection{Introduction}

In the last few years, the inflow of asylum seekers to the European Union (EU) has reached historically high levels. In 2015 , for instance, the number of individuals seeking refuge in an EU country increased from an average of around 200,000 a decade earlier to more than $1,300,000 .{ }^{55}$ Although many countries have taken actions that have substantially reduced the inflow, the recent surge in newly arrived asylum seekers and their families will in the coming years continue to raise share of refugee children in school.

While large disparities in educational performance between immigrants and natives have been documented throughout the EU (e.g. Schnepf, 2007) very little is known about the school achievements of refugees. The likely reasons are that most datasets do not separate between refugee migrants and other types of migrants and/or simply contain too few refugees to permit meaningful analyses. The lack of knowledge is problematic since refugees represent a particular disadvantaged group of migrants where one could expect children to face large difficulties in terms of school performance. Not only do refugees often face a direct threat of persecution or death due to the terrors of war or hunger, but are usually forced to a sudden move with limited or no resources available. ${ }^{56}$ This stands in stark contrast to other types of migrants where the cause of the move is often to improve the quality of life by finding work or education. These migrants are also often making a planned move and are able to safely return if unsuccessful.

55 http://ec.europa.eu/eurostat/statistics-explained/index.php/Asylum_statistics

${ }^{56}$ It is well recognized in the literature that childhood experiences such as malnutrition, mental disorders and family resources are linked to adverse human capital and health in the long run (e.g. Currie and Stabile, 2007 or Van den Berg, Pinger and Schoch, 2016). 
In contrast to many other European nations, Sweden has a long experience with accommodating refugees. In fact, refugee migration has been a major source of immigration since the mid-1980s (e.g. Lundh 2005). Because of its long experience with integrating refugee children in school, Sweden is potentially an interesting case study to learn more about what factors that promote integration.

The aim of this paper is firstly to describe the achievements of refugee pupils in compulsory school in Sweden. We also attempt to investigate what factors are important in explaining the school performance of refugee children. Here we target factors that have been raised in the previous literature as strong predictors of the achievements among ethnic minority students: parental socioeconomic status, neighborhoods and schools. Our focus on compulsory school is motivated by recent evidence in the economic literature that early measures of human capital are especially important in fostering the long-run accumulation of skills and thereby also promote economic opportunities in adulthood (e.g. Cunha and Heckman 2007). Numerous studies have documented that immigrants face substantial difficulties on the labor market. ${ }^{57}$ Differences in the early educational achievements among migrants who arrived as children might account for part of these ethnic disparities in the labor market.

In our analysis we use administrative data from Swedish records covering the period 1998-2014. The data contain information on grades for all students when they finish ninth grade (typically at age 16). These data have been linked by Statistics Sweden $(\mathrm{SCB})$ to other registers and we have information on the educational attainment and income of the parents. A key feature of the data is that it is possible to identify the cause of migration. We use this information to sort out children who arrived to Sweden as refugees (>74,000 students).

We start by describing the school performance of refugee students and show that there is a substantial gap between refugees and other students both in terms of GPA and the probability of qualifying for upper secondary school. For instance, in the year 2010 refugee students attained on average 17 percentile ranks lower GPA compared to all other students. The corresponding gap in the upper secondary school qualification rate is 25 percentage points. The difference is especially large for low-achieving students. While the gap was quite stable up until 2008 it has now increased

57 See e.g. Arai, Schröder and Vilhelmsson (2000), Bevelander and Skyt Nielsen (2001), Carlsson and Roth (2007), Engdahl (2014), Ekberg and Gustafsson (1995), Eriksson (2011), Hammarstedt and Shukur (2007), le Grand and Szulkin (2002), Lundh (2005), Nekby (2002), Åslund, Edin and LaLonde (2000). 
considerably. We find evidence that the reason is mainly because refugees tend to arrive at an older age. Previous research by Böhlmark (2008) has shown that immigrants who arrive at an older age (especially after age 9) perform substantially worse relative to immigrants who arrived when younger..$^{8} 59$

There are many potential causes of the disparities in educational achievements that we document. While it is difficult to sort out all potential mechanisms only using administrative data we are able to provide evidence on some channels that have been argued to play a big role in explaining ethnic achievement gaps. ${ }^{60}$ One of the strongest predictors of educational success in the total population is parental socioeconomic background (see Björklund et al. 2010, Holmlund et al. 2014 or Holmlund 2015 for Swedish evidence). A number of studies have also shown that parental socioeconomic status plays a big role for the educational attainments of children born abroad (e.g. Ammermueller 2007, Niknami 2014, Gang and Zimmermann 2000, Schneeweis 2011).

Another potential channel is access to good schools. If school quality matters for educational achievement (as shown by e.g. Gould, Lavy and Paserman 2004) and refugee children sort into schools of lower quality this could potentially account for the gap. Dustmann, Machin and Schönberg (2010) present evidence that differences in access to good schools explain part of the initial gap between different minority groups in the United Kingdom. In a similar way, a large literature has shown that differences in neighborhood quality (such as the level of income and ethnic segregation) contribute in explaining differences in educational outcomes (e.g. Borjas 1995; Chetty, Hendren and Katz 2015; Åslund, Edin, Fredriksson, and Grönqvist 2011; Grönqvist 2006; Grönqvist, Niknami and Robling 2015).

We find that controlling for parental socioeconomic background using data on parents' highest completed level of education and annual earnings substantially reduces the differences in school performance between refugees and other students. We also show that while school sorting only explains a small (albeit non-trivial) part of the gap, neighborhood of residence is also found to explain a considerable portion of

\footnotetext{
$5^{8}$ Similar patterns have been documented in many other countries. Van Ours och Veenman (2006), for instance, present evidence for the Netherlands.

59 The composition of region of origin is found to be of less importance in explaining the recent increase in the gap. However, our analysis is restricted by the fact that we only have access to region of birth at a very aggregated level (10 regions).

${ }^{60}$ In work for the Expert Group on Public Economics Studies (ESO) we are using administrative data merged to survey data that will allow us to paint a more complete picture of the school performance of immigrants (see Grönqvist and Niknami, 2017).
} 
the gap. In fact, conditioning on both parental socioeconomic status and neighborhood/school almost completely eliminates the gap.

Although we are aware of no previous study that analyzes the educational achievements among refugees, there have been a few attempts to address this issue for the total population of immigrants. ${ }^{61}$ One study that is of particular interest is by Bratsberg, Raum and Röed (2012) who use Norwegian administrative data to examine how immigrants (both first and second generation) differ from natives with respect to the likelihood of completing upper secondary school. They show that the upper secondary school completion rate is substantially lower among immigrants compared to natives but that the gap has decreased in the last two decades. A noteworthy finding is also that controlling for compulsory school GPA closes the gap. Another relevant study is by Wind Fallesen (2015) who replicates the analysis by Bratsberg, Raum and Röed using Danish register data for the period 1990-2007. She shows that there is a large gap in upper secondary completion between immigrants and natives also in Denmark. Wind Fallesen also show that family background explains a large portion of the overall gap. Just as the study by Bratsberg, Raum and Röed, she finds that the gap disappears when adjusting for compulsory school GPA. Although there are likely to be many unobserved correlates with compulsory school GPA, one way to interpret this finding is that interventions that promote achievements among migrants already in compulsory school could also help reducing long run socioeconomic disparities.

Our paper is also related to Dustmann, Machin and Schönberg (2010) who analyze the achievement gap in compulsory school between different ethnic minorities in the United Kingdom. Poverty is found to explain a large share of the overall gap between students of different ethnicities. As already mentioned, part of the gap is also due to the fact that minorities tend to sort into worse schools. Other European studies that document differences in achievements between immigrants and natives include: Ammermueller (2007), Jakobsen and Smith (2006), Riphahn (2003), Schneeweis (2011) and Schnepf (2007).

\footnotetext{
${ }^{61}$ Swedish evidence is scarce but there is some prior work on the performance of immigrants in school. For instance, although not being the main focus of the study, Holmlund et al. (2014) present some evidence on the achievement gap between immigrants and native students in compulsory school showing that there is indeed a large gap but adjusting for the fact that the composition of source countries has changed over time, as well as the fact that there has been a trend towards arriving to Sweden when being older, partially closes the gap. Skolverket (2016) provides another attempt to document the gap between immigrants and natives in Swedish compulsory school. Grönqvist and Niknami (2017) present further empirical evidence on this issue using unique linked register-survey data.
} 
The remainder of this paper is structured as follows. In Section 5.3 we discuss details regarding the institutional context relevant for interpreting our findings. Section 5.4 describes the data. Our results are presented in Section 5.5 and Section 5.6 concludes.

\subsection{Institutional context}

\subsubsection{Refugees in Swedish schools}

The inflow of migrants to Sweden has for more than three decades been composed of a large share of refugees. This is naturally also reflected in a large share of refugees in school relative to many other EU countries. In our data, $44.6 \%$ of all (non-adopted) immigrant children in compulsory school arrived to Sweden as refugees, $45.6 \%$ arrived as family reunification migrants and $9.8 \%$ immigrated for other reasons (e.g. children of labor migrants). Figure 1 shows the fraction of refugee students who finished gth grade between 1998 and 2014. We can see that the fraction of refugees was close to $5 \%$ in the early oos. This peak was primarily a consequence of the large waves of asylum seekers arriving in the mid-gos due to the collapse of Former Yugoslavia. The fraction of refugees then fell but started to increase rapidly again in the year 2009 and is expected to continue increasing in the coming years due to the many asylum seekers that have arrived recently.

In Sweden, municipalities are responsible for the education of newly arrived refugees. Newly arrived refugee children are typically placed in special preparatory classes that are often separated from the rest of the student population and vary in their duration. Children arriving at an early age are however often directly integrated in regular classes (FORTE 2016). As pointed out by Bunar (2010), there is a substantial lack of knowledge about the school performance of refugee children.

\subsubsection{Policy reforms}

Several major changes regarding school policy that potentially are relevant for interpreting our results have been implemented since the 1990s. These reforms have been documented extensively in other studies (e.g. Holmlund et al. 2014, and Skolverket 2009). We base our discussion below on these studies and refer to them for more details. 
Figure 1: Fraction of refugee pupils in gth grade over the period 1998-2014

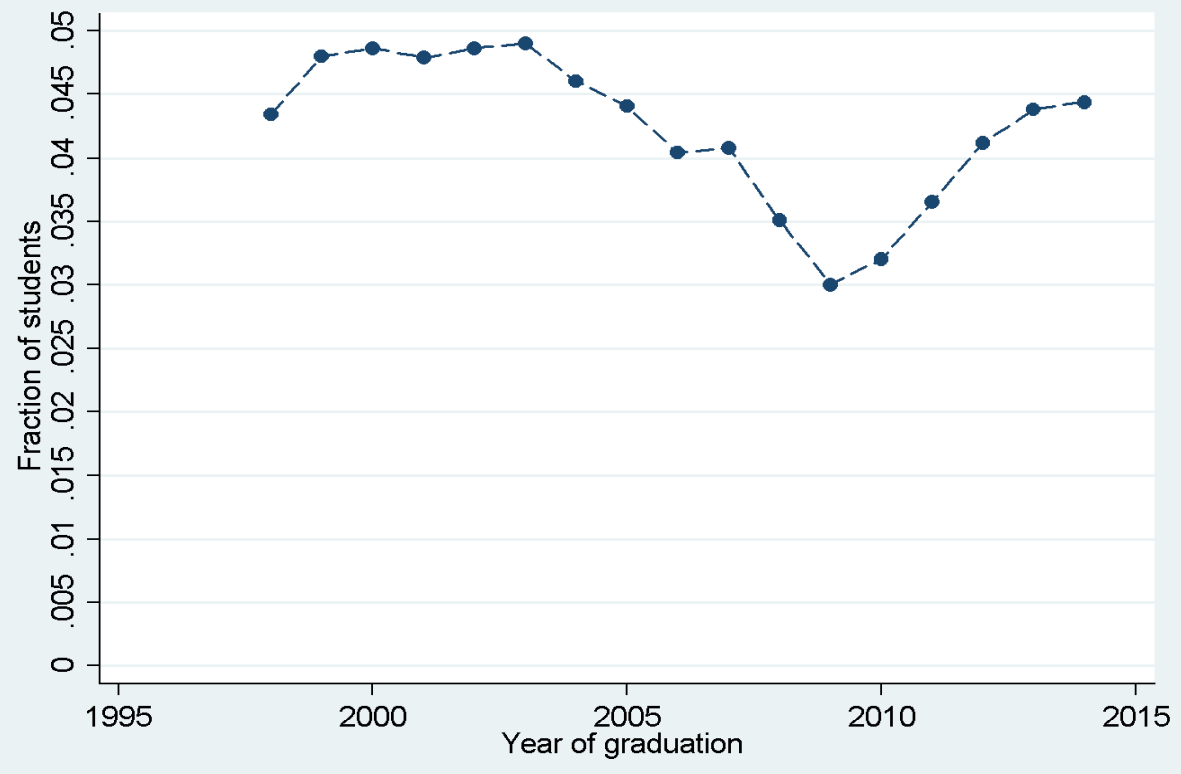

Note: The sample consists of all students who finished gth grade between 1998 and 2014. Authors own calculations based on register data.

The changes in school policy that occurred since the 1990 s can broadly be summarized as an attempt to generate a more decentralized school system. The general idea behind the reforms was that a more decentralized system would promote student learning, increase teachers' independence and lead to a more efficient use of resources. Of special relevance for the present study are the series of reforms that led to increased school choice. In 1992 students and their parents were allowed to freely choose school without considering its geographic location. Up until that point students had been allocated to schools based on the residence principle which meant that students attended the school that was closest to their home. The same year, private schools were granted the same financial resources as public schools and reimbursed with a fixed amount per student. The system, which implies that the voucher follows the pupil to her school, gave rise to a new type of non-public schools called "independent schools". The number of independent schools has since 1993 increased by more than an order of 
magnitude (Böhlmark, Holmlund and Lindahl 2015). Independent schools are however not permitted to select pupils by ability and are not endorsed to top up tuition fees in excess of the voucher.

The combination of these reforms meant that students and parents gained increased influence over the choice of school in a way that have been shown to promote the non-random sorting of students across schools. Böhlmark, Holmlund and Lindahl (2015) show that overall school segregation has increased between pupils characterized by native/immigrant background since the reforms. ${ }^{62}$ Many scholars believe that this type of segregation might hurt the performance of disadvantaged groups of students through peer effects; although, while evidence regarding immigrant students is lacking, there is no evidence that the introduction of independent schools in Sweden decreased the performance in the overall body of students (e.g. Böhlmark and Lindahl 2015).

Also the standards of grading students underwent large changes. Up until 1997 students were given relative grades (on a scale 1-5) where performance was compared to other students. This system was abolished in favor of one that formulated explicit absolute knowledge goals. If the student achieved a certain goal then (s)he was awarded with a grade that coincided with that particular goal. There is some evidence that increased competition among schools following the reforms in the early $1990 \mathrm{~s}$ coupled with the change from a relative to absolute grading system has led to grade inflation in Swedish schools (e.g. Vlachos 2010). ${ }^{63}$

\subsection{Data}

Our analysis is based on detailed data from various registers maintained by Statistics Sweden (SCB). The data include information from the "Grade 9 register" on all students who have finished gth grade between 1998 and 2014. This register contains details on the grades in all subjects the student has taken. Children are in the data linked to their parents and siblings using the "Multi-generation register". Other registers that provide

\footnotetext{
62 They also show that neighborhood segregation is the most important factor in explaining school segregation and that region where school choice became more prevalent, school segregation increased over and beyond what one should expect from neighborhood sorting.

${ }^{6}$ In our analysis we account for national trends in grade inflation by controlling for graduation cohort fixed effects and/or focusing on relative GPA comparisons within each graduation cohort.
} 
useful information are LISA and STATIV. We use the former to obtain information on each student's gender, region of origin and year of immigration. Region of origin is a (rather crude) aggregation of various countries of birth (e.g. Africa or Asia). LISA is also used for collecting details on parents' highest completed level of education, annual earnings and place of residence. Place of residence is observed at the so called SAMS level (Small Area Market Statistics), which is a national division of areas constructed by Statistics Sweden to facilitate the planning of municipal operations. The borders are drawn so that each area should be homogenous with respect to factors such as type of housing or industry mix. There are slightly more than 9,000 SAMS areas in Sweden and the average SAMS hosts just over 1,000 individuals. The exact area does however vary with slightly smaller areas being overrepresented in big cities. Information on type of residence permit (i.e. cause of immigration) is collected from STATIV.

Our main variables of interest are the GPA when finishing compulsory school and an indicator for the student having qualified for upper secondary education. During the period we study, students had to pass Math, English and Swedish (or Swedish as 2nd language) in order to be eligible to apply to upper secondary school. In order to ease interpretation and also adjust for potential grade inflation over time we use the percentile rank of GPA computed for each graduation cohort.

Table 1 presents descriptive statistics both for the variables we use in the empirical analysis and some other variables. We show statistics both for refugees and for all other students who finished grade 9 in the years 2000 and 2010 . About $95 \%$ of the other students are born in Sweden and the rest are children who immigrated for other reasons. There are potentially other relevant groups of students that may serve as comparisons to the refugees (e.g. natives, children of labor migrants, family reunification migrants, 2nd generation immigrants etc.). In order to keep the exposition simple we will however in the analysis use all other (non-refugee) students as the sole benchmark, except for in a few cases in the graphical analysis where we compare refugees with native students. We target these years because we wish to highlight some important changes that have occurred over this period. We can see that refugees on average have significantly lower compulsory school GPA. The difference in average GPA between refugees and other students is about 10 percentile ranks in the year 2000 and about 16 ranks in 2010. Similarly, there is also a large difference in the share of students who qualify for upper secondary education. While $77 \%$ of the refugee students qualified for upper secondary school in the year $2000,92 \%$ of all other students qualified. In the year 2010 this gap had 
grown to 26 percentage points. We will shortly return to look at the changes in these outcomes that occurred over time in greater detail.

There are also some notable differences in terms of background characteristics for the two groups. In both periods, refugees are substantially less likely to have at least one parent that has completed university. For instance, in the year 2010, only $36 \%$ of the refugee students have at least one university educated parent. The corresponding number for other students is $47 \%$. There is also a large difference when looking at parental earnings. For example, in 2010 other students had fathers who earned on average three times more than fathers of refugee students. It is also much more likely that refugee students are living in a major city (21 versus $14 \%$ in the year 2010). There are also some noteworthy differences in terms of the characteristics of schools the two groups attend. Refugee students on average finish compulsory school in schools that with a slightly lower average GPA compared to natives. They also attend schools with a considerably larger fraction of immigrants.

Two potentially relevant findings appear when considering the changes in background characteristics that have occurred over time. Firstly, the gap in parental earnings between refugees and other students increases substantially in the sense that the growth in earnings among parents to other students outgrows that of parents to refugee students. Secondly, refugee children arrive to Sweden when older. In 2000 the average age at immigration was 8.4. In 2010 this number was 9.7.

Table 1 also shows the regions of origin for the sample of refugees. In the year 2000 the largest region of origin was non-EU European countries. This group includes children from the large refugee migration waves from former Yugoslavia in the mid 1990s. The second and third largest groups were from Asia and Africa. Between the years 2000 and 2010 refugee migration from countries in Africa and Asia increased likely due to a rise in immigration from Afghanistan and countries in East Africa. ${ }^{64}$

\footnotetext{
64 There is also a small share of refugees from EU-countries. These are likely to be children who arrived from Eastern Europe before the latest major expansion of EU that started in 2004 and subsequently included these countries.
} 
Table 1: Descriptive statistics for selected variables and years, mean values

\begin{tabular}{|c|c|c|c|c|}
\hline & \multicolumn{2}{|c|}{ In year 2000} & \multicolumn{2}{|c|}{ In year 2010} \\
\hline & $\begin{array}{r}\text { Refugees } \\
(4,474)\end{array}$ & $\begin{array}{r}\text { Other students } \\
(90,320)\end{array}$ & $\begin{array}{r}\text { Refugees } \\
(3,498)\end{array}$ & $\begin{array}{r}\text { Other students } \\
(110,823)\end{array}$ \\
\hline Grade point average (pct. rank) & 39.46 & 49.67 & 33.4 & 49.63 \\
\hline Qualified for upper secondary school & .77 & .92 & .64 & .90 \\
\hline Age when finishing grade 9 & 16.2 & 16.0 & 16.3 & 16.0 \\
\hline Female & .49 & .49 & .46 & .49 \\
\hline At least one parent completed university & .34 & .47 & .36 & .51 \\
\hline Earnings mother (SEK) & 78,285 & 175,901 & 95,751 & 261,630 \\
\hline Earnings father (SEK) & 102,257 & 265,782 & 112,363 & 368,844 \\
\hline Live in major city & .27 & .12 & .21 & .14 \\
\hline Age at immigration & 8.4 & $\mathrm{~N} / \mathrm{A}$ & 9.7 & N/A \\
\hline \multicolumn{5}{|l|}{ School characteristics } \\
\hline Average GPA & 45.6 & $49 \cdot 4$ & 44.1 & $49 \cdot 4$ \\
\hline Number of students finishing grade 9 & 113 & 110 & 101 & 103 \\
\hline Fraction with university educated parents & .40 & .46 & .43 & .51 \\
\hline Fraction of immigrants & .23 & .07 & .18 & .06 \\
\hline \multicolumn{5}{|l|}{ Region of origin among refugees } \\
\hline Africa & .07 & & .11 & \\
\hline Asia & .39 & & .54 & \\
\hline South America & .06 & & .04 & \\
\hline Europe EU & .07 & & .07 & \\
\hline Europe non-EU & .40 & & .22 & \\
\hline Other regions & .02 & & .02 & \\
\hline
\end{tabular}

Note: The sample consists of all students who graduated each year. Authors own calculations based on their register data.

\subsection{Results}

This section presents the results from our empirical analysis of the compulsory school performance of refugee children. We start by showing some simple graphs and then proceed to results from formal regressions. In the graphical analysis we compare the achievements of refugees to that of natives (or the national average of all students) because we wish to relate our results to previous studies. As discussed earlier, in order to keep the exposition concise in our regressions we use all other (non-refugee) students as a single reference group. 


\subsubsection{A visual illustration of the achievement gap}

Figure 2 displays the development of GPA for refugee students between 1998 and 2014 . We can see that refugees throughout the entire period have performed poorly. The difference in GPA between refugee students and the national average of all students was stabile around 10 percentile ranks up until about 2008 after which there is a sharp increase of the gap to about 16 percentile ranks.

Figure 2: Development of GPA over time

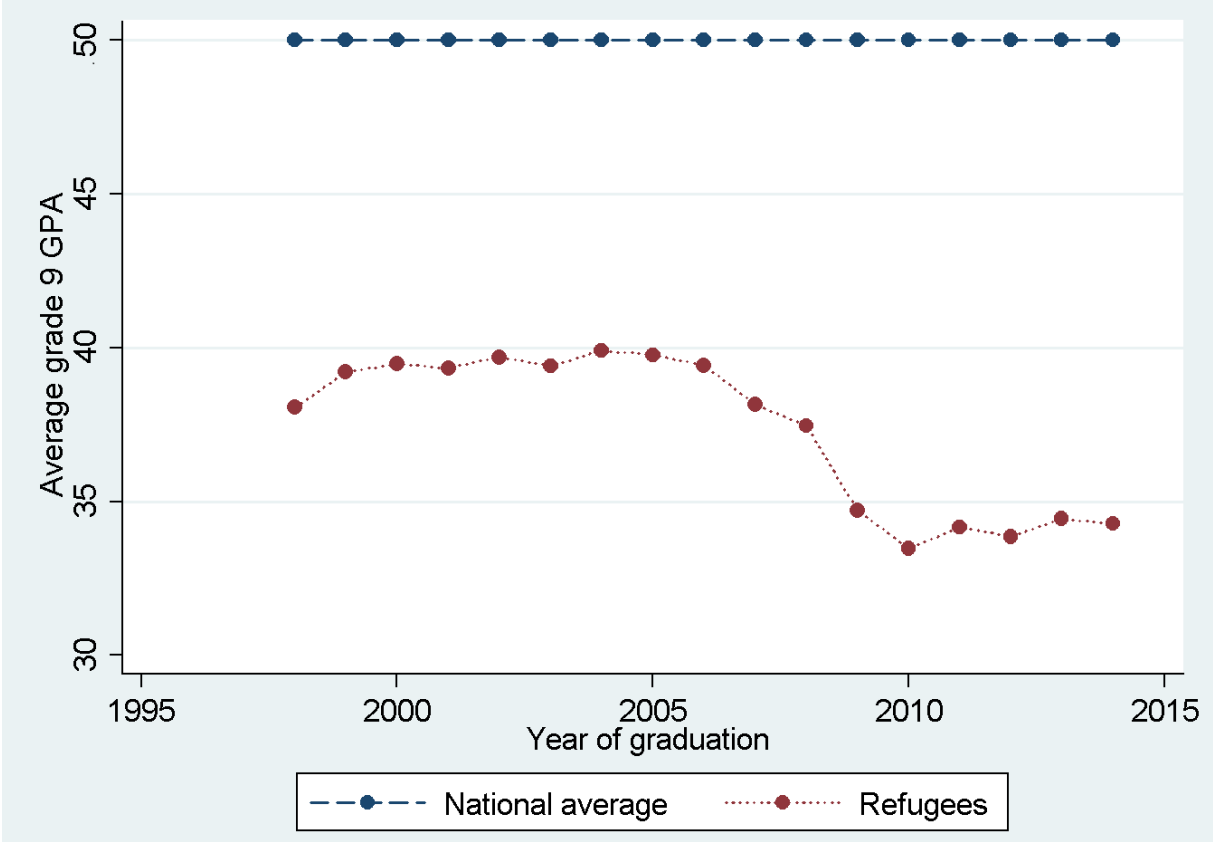

Note: The sample consists of all students who graduated each year. Authors own calculations based on register data.

An alternative but highly relevant way to view student achievement is to consider the qualification rate for upper secondary school. Figure 3 plots the development over time in the fraction of refugee students that have passed Mathematics, English and Swedish and thereby gained the right to apply to upper secondary school. We do this also for native students for comparison. We see large differences between refugees and native students. There is a large gap that increases sharply around the year 2008. In the latest 
year for which we have data we can see that while on average more than $90 \%$ of native students qualify for upper secondary school, the same figure is $65 \%$ among refugees, i.e. a $25 \%$ point difference. These are by all standards huge differences. Although the studies by Bratsberg, Raum och Röed (2012) and Wind Fallesen (2015) do not examine the upper secondary qualification rate but the upper secondary completion rate they show that the unadjusted difference in the completion rate between natives and immigrants born abroad is 17 percentage points in Bratsberg, Raum and Röed and 15 percentage points in the last observation year in Wind Fallesen.

Although the cause of the increase of the gap is not the main focus of our paper we performed an auxiliary analysis to sort out what lead to this sudden drop in the performance of these students. It has been shown previously that there was a sharp increase in the age of immigration about the time when the gap started to appear (Skolverket 2016). We also saw in Table 1 that the average age at immigration increased during this period. Age at immigration might matter for student achievement if arriving when older implies less time to integrate and arriving after the prime age for language acquisition (see Böhlmark 2008). Another potential candidate for the widening of the gap is a change in the composition of countries. In unreported regressions (available on request) we found that controlling for age at arrival explains about two thirds of the widening of the gap and controlling additionally for the composition of source countries further reduces it about $25 \% .{ }^{65}$ It therefore seems as if these demographic changes explain most of the increase in the achievement gap. ${ }^{66} 67$

\footnotetext{
65 This analysis was done by replacing the refugee dummy with dummies for each possible age at arrival (or region of origin). The average effect of refugee status is then calculated as the average of the coefficients on the age at arrival weighted by the share of children who arrived at a given age. Note also that we only have access to very broad categories of region of origin.

${ }^{66} \mathrm{It}$ is not clear why the mean age at immigration has increased but we note that there was also a sharp increase in $1994 / 1995$ that coincided with a large increase in refugee migration from former Yugoslavia. It therefore seems as if large upswings in refugee migration correspond to increases in the average age at immigration.

${ }^{67}$ In our analysis we include all children, also those with no parents in the registers. Since the average age among unaccompanied minors is higher than for children who arrived with their parents we performed extra analyses accounting for children who arrived to Sweden alone with no parents already present but found no evidence that this group of refugees is driving the results in any meaningful way.
} 
Figure 3: Development of the upper secondary school qualification rate over time

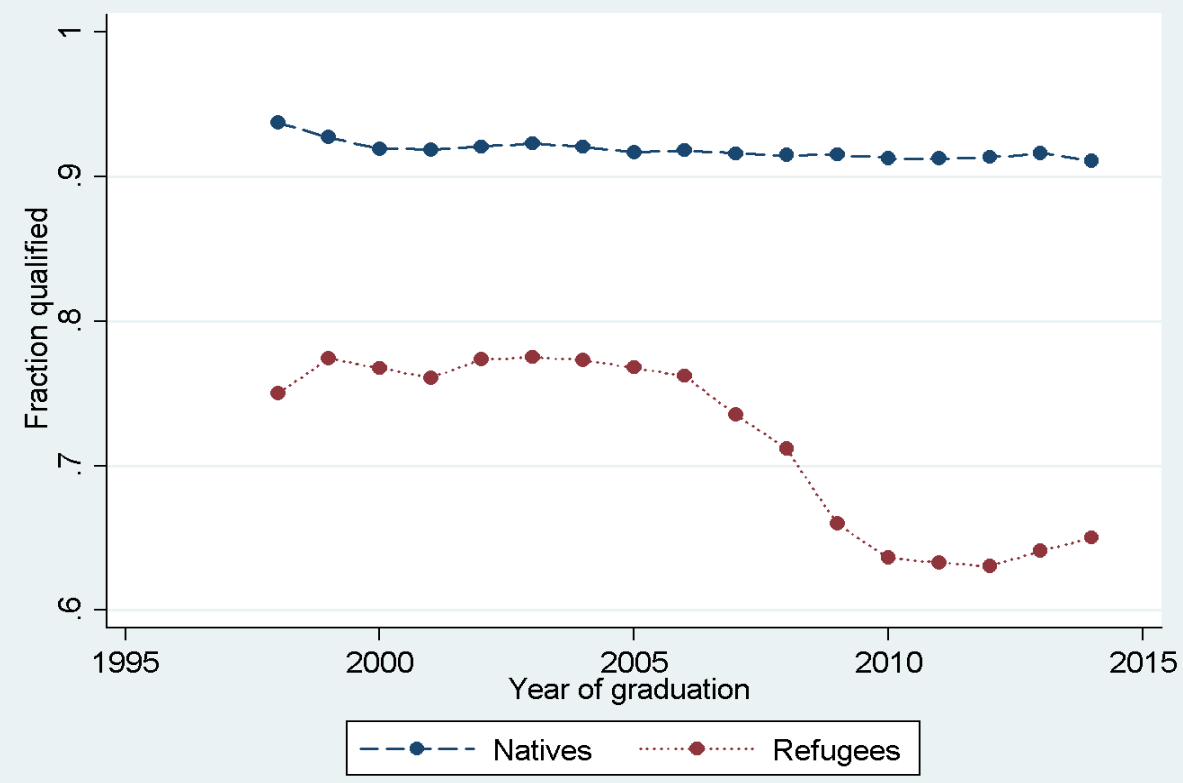

Note: The sample consists of all students who graduated each year. Authors own calculations based on their data.

By focusing only on comparing sample averages one risks masking potentially relevant information that may be hidden in the full distribution of achievements. Figure 4 plots Kernel density estimations of the distribution of GPA (normalized by year of graduation) separately for refugees and native students for the years 2000 and 2010 . In the first year we see that the lower part of the distribution is much thicker for refugee students compared to native students. This suggests that a larger fraction of refugees are low achievers compered to natives. It is also interesting to note that the proportion of low achieving refugee students increase between 2000 and 2010. 
Figure 4: Distribution of GPA in 2000 and 2010
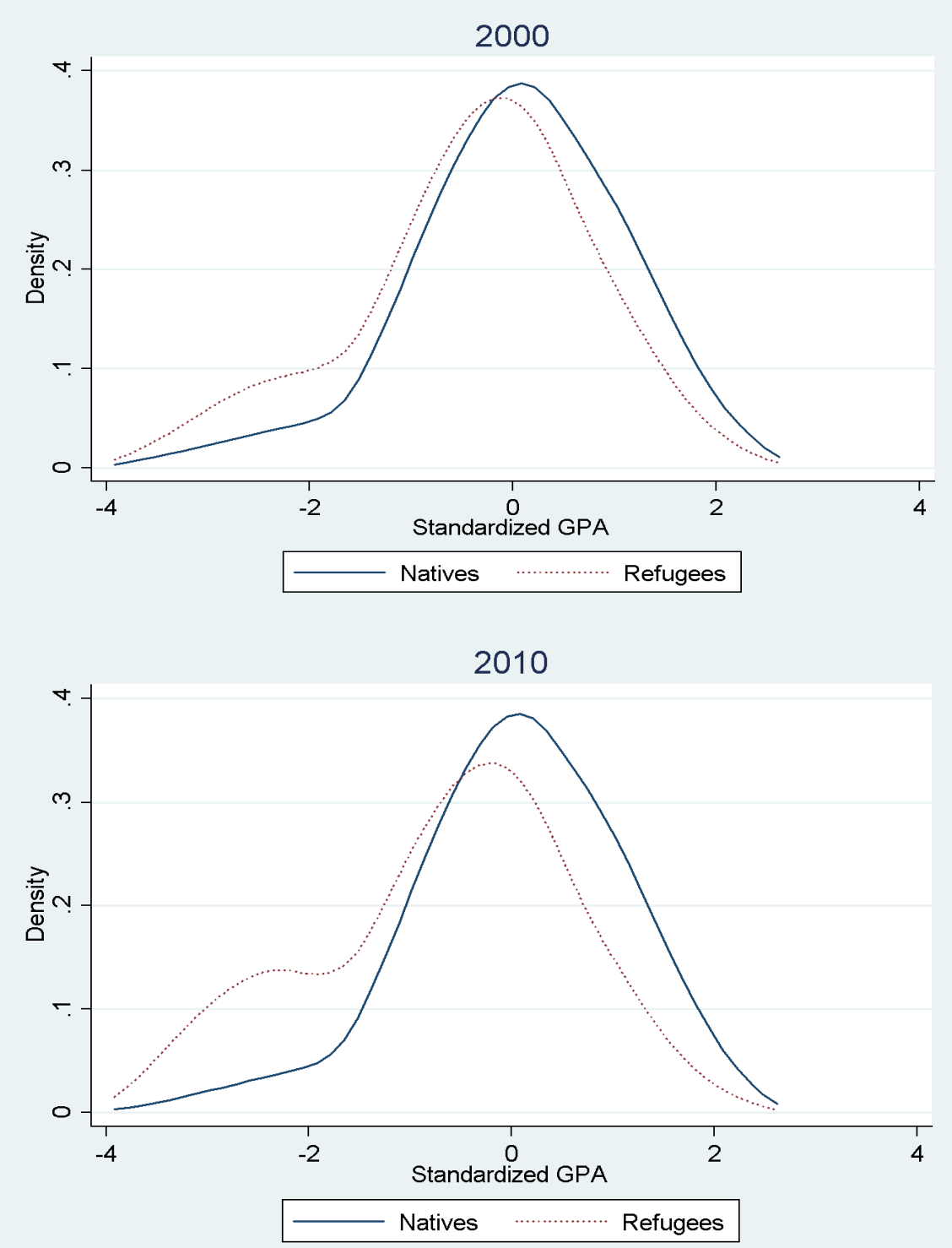

Note: The figure presents Kernel density plots of the distribution of GPA (normalized to mean zero, SD unity). The sample consists of all students who graduated each year. Authors own calculations based on register data. 


\subsubsection{Regression analysis}

Before proceeding to investigating the mechanisms that could explain the achievement gap we start by showing evidence on possible subgroup heterogeneity. Table 2 shows results from regressions where the dependent variable is either percentile ranked GPA (Panel A) or the probability of qualifying for upper secondary school (Panel B) and the independent variable of interest is a dummy for the student being a refugee. The reference group is all other (non-refugee) students. The regressions only control for gender and cohort of graduation.

Column (1) shows results for the full sample and then in columns (2)-(7) we stratify the sample by gender, parental education and urban/rural city status. We can see that the gap in the full sample is 12 percentile ranks for GPA and 19 percentage points for the probability of qualifying for upper secondary school. When looking at gender differences there is a slightly bigger gap in achievements for girls than boys when considering GPA. For the probability of qualifying for upper secondary school, however, the difference is larger for boys. Turning to parental education we can see that the gap is larger among children where at least one of the parents has completed university education compared to students where no parent has finished university. Columns (6) and (7) break the sample down by urban status. We define urban students as students who finished grade 9 in one of Sweden's three largest municipalities (Stockholm, Gothenburg and Malmö) and rural students as all other students. We find no major differences in the size of the gap. In sum, the gap seems fairly stable across different population subgroups. What stands out is however that the gap is larger among children with university educated parents.

Next, we continue by probing the mechanisms that might underlie the achievement gap. As already mentioned, we focus on factors that have been shown to matter for ethnic achievement gaps in other studies. We start by examining the importance of parental background in Table 3 and then continue with the role of schools and neighborhoods in Table 4. The basic idea behind our empirical approach is simple. We start with a baseline model that only includes a limited set of controls and then successively include more controls in the model. If the achievement gap is driven by the factors we control for then any change in the gap could then be attributed to that specific factor. It is important however to mention that there are likely many unobserved factors that potentially are linked both to the factor we wish to study and to the size of the achievement gap. Consequently, we make no claim to identify causal 
relationships. We are however still able to assess the relative importance of the underlying mechanisms and to rule out pathways that contribute very little to the gap.

Table 2: Differences in compulsory school outcomes between refugees and other students

\begin{tabular}{|r|r|r|r|r|}
\hline Full & Boys (2) & Girls (3) & $\begin{array}{r}\text { Low } \\
\text { educated } \\
\text { parent (4) }\end{array} \begin{array}{r}\text { High } \\
\text { educated } \\
\text { parents (5) }\end{array}$ \\
\hline
\end{tabular}

Panel A. Dependent variable (pct. rank) GPA

\begin{tabular}{|c|c|c|c|c|c|c|c|}
\hline Refugee $=1$ & $\begin{array}{r}-12.0^{*} \\
(.11)\end{array}$ & $\begin{array}{r}-10.9^{*} \\
(.14)\end{array}$ & $\begin{array}{r}-13.1 * \\
(.16)\end{array}$ & $\begin{array}{r}-7.8 * \\
(.12)\end{array}$ & $\begin{array}{r}-12.1^{*} \\
(.18)\end{array}$ & $\begin{array}{r}-14.1^{*} \\
(.25)\end{array}$ & $\begin{array}{r}-11.0^{*} \\
(.12)\end{array}$ \\
\hline \multicolumn{8}{|c|}{ Panel B. Dependent variable: P (Qualify for upper sec. school) } \\
\hline Refugee $=1$ & $\begin{array}{c}-.19 * \\
(.00)\end{array}$ & $\begin{array}{c}-.20^{*} \\
(.00)\end{array}$ & $\begin{array}{l}-.17^{*} \\
(.00)\end{array}$ & $\begin{array}{r}-.12 * \\
(.00)\end{array}$ & $\begin{array}{c}-.20^{*} \\
(.00)\end{array}$ & $\begin{array}{c}-.18 * \\
(.00)\end{array}$ & $\begin{array}{c}-.16^{*} \\
(.00)\end{array}$ \\
\hline
\end{tabular}

Note: The table presents the coefficient on a dummy taking the value one for being a refugee and zero otherwise. Each table entry represents a separate regression. The dependent variable in Panel A is percentile ranked compulsory school GPA (computed by cohort of graduation). The dependent variable in Panel $B$ is the probability of having qualified for upper secondary school (i.e. having passed all subjects: Mathematics, English and Swedish) and the sample mean is .90. The sample consists of all students $(1,828,136)$ who finished compulsory school between 1998 and 2014 . The regression model in column (1) (estimated by OLS) only controls for gender and year when finishing compulsory school. High educated parents in column (5) is defined as at least one parent having completed university education and low educated parents in column (4) is the remainder of the sample. Column (6) is restricted to students who finished compulsory school in one of Sweden's three largest municipalities (Stockholm, Gothenburg and Malmö). Column (7) is students in all other municipalities. Robust standard errors are shown in parentheses. * = significant at $5 \%$. Authors own calculations based on register data.

Column (1) in Table 3 shows the baseline results where we only control for gender and cohort of graduation. We start by adding to the baseline model in column (1) controls for parental education. We adopt a quite flexible approach here and control for all possible combinations of parent's highest completed level of education ( 16 cells). We can see that introducing this control decreases the gap by more than $50 \%$ for GPA and slightly less than $50 \%$ for the probability of qualifying for upper secondary education. ${ }^{68}$ Column (3) adds to the baseline regression model in column (1) controls for each parent's annual

\footnotetext{
${ }^{68}$ It turns out that the results are remarkably similar when introducing controls for missing education of the parent into the regressions.
} 
earnings measured in the year the children finishes gth grade. We can see that controlling for earnings instead of education reduces the gap slightly more for GPA but slightly increases it for the qualification rate to upper secondary school. Column (4) conditions both on education and earnings. Compared to the baseline model controlling for these variables simultaneously substantially reduces the achievement gap for GPA by $75 \%$ and shrinks the gap in the qualification rate by more than $50 \%$.

Needless to say, parental socioeconomic background is difficult to measure and there could quite well be other dimensions of socioeconomic status that we fail to control for using parental education and earnings. Columns (5) and (6) address this by focusing on within-sibling contrasts in the achievement gap. The coefficient of interest is identified from families in which one child arrived as a refugee and the other(s) where born in Sweden or possibly arrived later as another migrant type. The benefit of this approach is that it controls for all family characteristics that are shared by the siblings such as socioeconomic status in some unobserved dimension. It also controls for parental country of origin. Recall that we have quite crude measures of origin based on large aggregations on source countries. For this analysis we need to restrict the sample to families that have at least two children who have finished grade nine between 1998 and 2014. It is however important to understand that the parameter that is identified using within-sibling variation is different than in the baseline. Not only does the strategy ignores children with no siblings, but the difference in outcomes between siblings where one arrived as refugee and the other as another type of migrant is likely of a different nature than the difference between refugees and non-refugees in the total population.

We can see in column (5) that there is no meaningful difference in the size of the GPA achievement gap when controlling for family fixed effects compared to when controlling both for parents' education and earnings. However, the gap in the qualification rate to upper secondary school is eliminated. In column (6) we add to column (5) controls for parental education and earnings. These coefficients are identified since the variables are measured in the year the child finishes compulsory school (and thus varies between siblings). The results are very similar to those in column (5). ${ }^{69}$

\footnotetext{
69 Bratsberg et al. (2012) show that it is important to account for the possibility that the importance of parental educational attainment might differ for natives and immigrants. The fact that our family fixed effect analysis show similar results suggests that this is not the case in our specific context. Yet, we also experimented with allowing for separate coefficients on parental background for refugees and other students and found no major differences in the results.
} 
To summarize, parental background is found to be very important in explaining the compulsory school achievement gap between refugees and other students. Controlling for parental background closes the GPA gap by more than $75 \%$ and completely eliminates the differences in the probability of qualifying for upper secondary school.

Next we target the role of schools and neighborhoods in explaining the school performance of refugees. The choice of neighborhoods and schools is likely to be intimately liked to parental background. Before investigating what happens to the remainder of the achievement gap when conditioning the analysis on all these variables simultaneously we go back to our baseline model that only controls for gender and cohort and then introduce a new set of controls for schools and neighborhoods. This is done in order to better understand the relative merits of different factors. Column (2) in Table 4 controls for school fixed effects in addition to the controls in column (1). This controls for the sorting of students across schools which might differ across origins. If refugees end up in schools with fewer resources, worse teachers or less beneficial peer groups then this could potentially explain the differences in achievements between refugees and other students that we have documented. Recall that Dustmann, Machin and Schönberg (2010) find that the initial sorting of students across schools explain part of the ethnic achievement gap in the United Kingdom. Also, Böhlmark, Holmlund and Lindahl (2015) show that school sorting has increased in Sweden due to the reforms in the 1990 s that increased school choice. Although the results in column (2) suggest that school sorting matter for the achievement gap the magnitude of the reduction in the gap is much less than when controlling for parental socioeconomic background. For instance, while adjusting for parental background decreased the gap in GPA by more than $75 \%$, controlling for sorting across schools reduces it by slightly more than $25 \%$. 
Table 3: The importance of parental background

\begin{tabular}{|c|c|c|c|c|c|c|}
\hline & $\begin{array}{r}\text { Baseline } \\
\text { (1) }\end{array}$ & $\begin{array}{r}\text { Adjusting } \\
\text { for parents' } \\
\text { education } \\
\text { (2) }\end{array}$ & $\begin{array}{r}\text { Adjusting } \\
\text { for parents' } \\
\text { earnings } \\
(3)\end{array}$ & $\begin{array}{r}\text { Adjusting } \\
\text { for parents' } \\
\text { education } \\
\text { and earnings } \\
(4)\end{array}$ & $\begin{array}{r}\text { Adjusting } \\
\text { for family } \\
\text { fixed effects } \\
(5)\end{array}$ & $\begin{array}{r}\text { Col. (5) + } \\
\text { adjusting for } \\
\text { parents' } \\
\text { education } \\
\text { and earnings } \\
(6)\end{array}$ \\
\hline \multicolumn{7}{|c|}{ Panel A. Dependent variable (pct. rank) GPA } \\
\hline Refugee $=1$ & $\begin{array}{r}-12.0 * \\
(.11)\end{array}$ & $\begin{array}{l}-5.4^{*} \\
(.11)\end{array}$ & $\begin{array}{l}-3.7^{*} \\
(.13)\end{array}$ & $\begin{array}{r}-2.8 * \\
(.11)\end{array}$ & $\begin{array}{l}-2.5^{*} \\
(.29)\end{array}$ & $\begin{array}{r}-2.4^{*} \\
(.29)\end{array}$ \\
\hline \multicolumn{7}{|c|}{ Panel B. Dependent variable: $P$ (Qualify for upper sec. school) } \\
\hline Refugee $=1$ & $\begin{array}{r}-.19^{*} \\
(.00)\end{array}$ & $\begin{array}{r}-.10^{*} \\
(.00)\end{array}$ & $\begin{array}{l}-.12 * \\
(.00)\end{array}$ & $\begin{array}{r}-.09 * \\
(.00)\end{array}$ & $\begin{array}{l}-.01 \\
(.00)\end{array}$ & $\begin{array}{r}-.01 \\
(.00)\end{array}$ \\
\hline
\end{tabular}

Note: The table presents the coefficient on a dummy taking the value one for being a refugee and zero otherwise. Each table entry represents a separate regression. The dependent variable in Panel A is percentile ranked compulsory school GPA (computed by cohort of graduation). The dependent variable in Panel $B$ is the probability of having qualified for upper secondary school (i.e. having passed all subjects: Mathematics, English and Swedish) and the sample mean is .9o. The sample consists of all students $(1,828,136)$ who finished compulsory school between 1998 and 2014. The regression model in column (1) (estimated by OLS) only controls for gender and year when finishing compulsory school. Column (2) adds to column (1) controls for all interactions between parents' highest completed level of education (in total 16 cells including missing values). Column (3) controls linearly for parents' annual earnings separately for each parent along with controls for missing parent. Column (4) includes both controls in columns (3) and (4) simultaneously. Column (5) controls for family background where the coefficient is identified from differences in refugee status within siblings. Column (6) adds to column (5) controls for parental education and earnings. Robust standard errors are shown in parentheses. * = significant at $5 \%$. Authors own calculations based on register data.

In column (3) we control for area of residence in a broad way by adjusting for municipality of residence. We can see that controlling for municipality effects has very little influence on the achievement gap. In column (4) we attempt to control for place of residence at a finer level using SAMS areas. Neighborhoods have also been shown to matter for the outcomes of children in many ways. For instance, Grönqvist, Niknami and Robling (2015) show that segregated neighborhoods are causally linked to worse school performance among immigrant children. Neighborhood effects could matter because of the quality of local institutions, access to peers or positive role models, social capital etc. We can see that controlling for neighborhoods substantially reduces the gap compared to column (1) by about $75 \%$ for GPA and about $55 \%$ for the qualification rate 
to upper secondary school. As already noted, the choice of residential area is likely strongly linked to socioeconomic status. In column (5) we see what happens to the estimates when controlling simultaneously for neighborhood effects and parental socioeconomic status. We can see that doing so completely eliminates the gap in GPA and reduces the gap in the qualification rate by almost $80 \%$.

As a last word, it is possible that the importance of different mechanisms has varied over the time period we consider. For instance, it is plausible that both the role of residential segregation and that of parental background have changed across cohorts. We investigated this by estimating separate regressions by cohort of graduation (available on request) but found no meaningful differences in the results.

Table 4: The importance of schools and neighborhoods

\begin{tabular}{|c|c|c|c|c|c|}
\hline & $\begin{array}{r}\text { Baseline } \\
\text { (1) }\end{array}$ & $\begin{array}{r}\text { Ctrl. for } \\
\text { school } \\
(2)\end{array}$ & $\begin{array}{r}\text { Ctrl. for } \\
\text { municipality } \\
\text { (3) }\end{array}$ & $\begin{array}{r}\text { Ctrl. for } \\
\text { neighbourhood } \\
(4)\end{array}$ & $\begin{array}{l}\text { Ctrl both for } \\
\text { neighbhd and } \\
\text { parents' SES }\end{array}$ \\
\hline \multicolumn{6}{|c|}{ Panel A. Dependent variable (pct. rank) GPA } \\
\hline Refugee $=1$ & $\begin{array}{r}-12.0^{*} \\
(.11)\end{array}$ & $\begin{array}{r}-8.6 * \\
(.11)\end{array}$ & $\begin{array}{r}-11.1^{*} \\
(.11)\end{array}$ & $\begin{array}{r}-4.0 * \\
(.12)\end{array}$ & $\begin{array}{r}.01 \\
(.12)\end{array}$ \\
\hline \multicolumn{6}{|c|}{ Panel B. Dependent variable: P(Qualify for upper sec. school) } \\
\hline Refugee $=1$ & $\begin{array}{c}-.19^{*} \\
(.00)\end{array}$ & $\begin{array}{l}-.13^{*} \\
(.00)\end{array}$ & $\begin{array}{l}-.16 * \\
(.00)\end{array}$ & $\begin{array}{c}-.09 * \\
(.00)\end{array}$ & $\begin{array}{r}-.04^{*} \\
(.02)\end{array}$ \\
\hline
\end{tabular}

Note: The table presents the coefficient on a dummy taking the value one for being a refugee and zero otherwise. Each table entry represents a separate regression. The dependent variable in Panel A is percentile ranked compulsory school GPA (computed by cohort of graduation). The dependent variable in Panel $B$ is the probability of having qualified for upper secondary school (i.e. having passed all subjects: Mathematics, English and Swedish) and the sample mean is .9o. The sample consists of all students $(1,828,136)$ who finished compulsory school between 1998 and 2014 . The regression model in column (1) (estimated by OLS) only controls for gender and year when finishing compulsory school. Column (2) adds to column (1) controls for (mother's) municipality of residence when finishing gth grade. Column (3) adds to column (1) controls for (mother's) neighborhood (SAMS) of residence when finishing gth grade. Column (4) adds to column (1) controls for school. Column (5) adds to column (1) controls for neighborhood, school, each parents' highest completed level of education interacted ( 16 cells) and linearly for each parent's annual earnings simultaneously. Robust standard errors are shown in parentheses. * = significant at $5 \%$. Authors own calculations based on register data. 


\subsection{Concluding remarks}

Although the number of refugee students is increasing in many European countries very little is known about the school performance of this particularly disadvantaged group of migrants. This paper documents the achievement of refugee students in compulsory school in Sweden using rich register data for the period 1998-2014 with details not only on student performance for all students but also the possibility to separately identify migrants that have arrived to Sweden as refugees. Because of its long experience with hosting refugee migrants, Sweden represents an interesting case study for learning more about the integration of refugee children in school.

We find that refugee students on average perform significantly worse than natives in terms of their grade point average (GPA) and their likelihood of qualifying for upper secondary education. The difference has grown in the last few years, in particular among refugees in the lower part of the GPA distribution. Controlling for parental socioeconomic status reduces the gap significantly. Neighborhood sorting is also found to play a major role in explaining the gap. Controlling both for parental socioeconomic status and neighborhood almost completely eliminates the gap.

These findings are similar to those reported in Norway by Bratsberg, Raum and Röed (2012) and in Denmark by Wind Fallesen (2015); although these studies focus on upper secondary school and cannot identify refugees. Although our estimates should not be interpreted as causal the results suggests that policies that focus on improving the general socioeconomic situation of refugees should likely be of major importance in improving the school achievements of refugee students.

That said there are a number of different mechanisms that are likely to be correlated with parental socioeconomic background that may be of importance for the achievement gap but we were unable to learn about using the data at hand. For instance, socioeconomic background is probably linked to factors such as parenting style or preferences for child care. It therefore seems plausible that pre-school interventions and polices that promote parenthood education may also be useful. Separating between the roles of different mechanisms using richer data is an important avenue for future work. It might also be of interest to document the achievement gap in upper secondary school. 


\section{References}

Åslund, O., Edin, P-A., Fredriksson, P. and Grönqvist, H. (2011), Peers, neighborhoods, and immigrant student achievement: Evidence from a placement policy" ${ }^{\prime}$ American Economic Journal: Applied Economics, 3(2), 67-95. https://doi.org/10.1257/app.3.2.67

Arai, M. Schröder, L. and Vilhelmsson, R. (2000), En svartvit arbetsmarknad, Ds 2000:47, Expertgruppen för studier i offentlig ekonomi (ESO).

Ammermueller, A. (2007), "Poor background or low returns? Why immigrant students in Germany perform so poorly in the Programme for International Student Assessment", Education Economics, 15(2), 215-230. https://doi.org/10.1080/og645290701263161

Böhlmark, A. (2010), Age at immigration and school performance: A siblings analysis using Swedish register data, Labour Economics, 15(6), 1366-1387. https://doi.org/10.1016/j.labeco.2007.12.004

Böhlmark, A. Holmlund, H. and Lindahl M. (2015), School Ccoice and segregation: Evidence from Sweden", IFAU Working paper 2015:8.

Böhlmark, A. and Lindahl M. (2015), Independent schools and long-run educational outcomes: Evidence from Sweden's large scale voucher reform", Economica (forthcoming).

Borjas, G. (1995), Ethnicity, Neighborhoods, and Human Capital Externalities, American Economic Review, 85(3), 365-390.

Bevelander, P. and Skyt Nielsen H. (2001), Declining employment success of immigrant male $s$ in Sweden: Observed or unobserved characteristics?, Journal of Population Economics, 14, 455-471. https://doi.org/10.1007/s001480000036

Björklund, A. Fredriksson, P. Gustafsson, J-E. and Öckert B. (2010), Den svenska utbildningspolitikens arbetsmarknadseffekter: Vad säger forskningen?, IFAU Rapport 2010:13.

Björklund, A. Clark, M. Edin, P.-A. Fredriksson, P. and Krueger, A. (2005), The market comes to education - An evaluation of Sweden's surprising school reforms", Russell Sage Foundation.

Bratsberg, B. Raaum, O. and Röed K. (2012), Educating children of immigrants: closing the gap in Norwegian schools", Nordic Economic Policy Review, 3(1), 211-251.

Bunar, N. (2010), Nyanlända och lärande. En forskningsöversikt om nyanlända elever i den svenska skolan, Vetenskapsrådets rapportserie nr 6 .

Carlsson, M. and Rooth, D-O. (2007), Evidence of ethnic discrimination in the Swedish labor market using experimental data, Labour Economics, 14, 716-729.

https://doi.org/10.1016/j.labec0.2007.05.001

Chetty, R., Hendren, N. and Katz, L. (2015), The effects of exposure to better neighborhoods on children: New evidence from the moving to opportunity project", forthcoming in the American Economic Review.

Cortes, K. (2006), The effects of age at arrival and enclave schools on the academic performance of immigrant children, Economics of Education Review, 25(2), 121-132. https://doi.org/10.1016/j.econedurev.2004.12.001

Cunha, F. and Heckman, J. (2007), The technology of skill formation", American Economic Review, 97(2): 31-47. https://doi.org/10.1257/aer.97.2.31 
Currie, J. and Stabile, M. (2007), Mental health in childhood and human capital, in An Economic Perspective on the Problems of Disadvantaged Youth, Jonathan Gruber (ed.), Chicago:

University of Chicago Press. https://doi.org/10.3386/w13217

Dustmann, C. Machin, S. and Schoenberg, U. (2010), Ethnicity and Educational Achievement in Compulsory Schooling, Economic Journal, 120(546), F272-F297. https://doi.org/10.1111/j.14680297.2010.02377.x

Edin, P-A. LaLonde, R. and Åslund, O. (2000), Emigration of immigrants and measures of immigrant assimilation, Swedish Economic Policy Review, 7, 163-204.

Engdahl, M. (2014), "Naturalizations and the economic and social integration of immigrants", IFAU Working-paper 2014:11.

Ekberg, J. and Gustafsson B. (1995), Invandrare på arbetsmarknaden, SNS förlag, Stockholm.

Eriksson, S. (2011), Utrikesfödda på den svenska arbetsmarknaden, Långtidsutredningen, Bilaga 4

FORTE (2016), Nyanlända barn och den svenska mottagningsstrukturen, Rapport

Gang, I. and Zimmermann, K. (2000), Is childlike parent? Educational attainment and ethnic origin, Journal of Human Resources, 35, 550-569. https://doi.org/10.2307/146392

Gould, E. Lavy, V. and Paserman, D. (2004), Immigrating to opportunity: Estimating the effect of school quality using a natural experiment on ethiopians in Israel, Quarterly Journal of Economics, 489-525. https://doi.org/10.1162/0033553041382193

Grönqvist, H. (2006), Ethnic enclaves and the attainments of immigrant children", European Sociological Review, 22(4), 369-382. https://doi.org/10.1093/esr/jcloo2

Grönqvist, H. and Niknami, S. (2017), Samma möjligheter: En ESO-rapport om skillnaden i studieresultat mellan inrikes och utrikes födda elever, Report for The Expert Group in Public Economics.

Grönqvist, H. Niknami, S. and Robling, P-O. (2015), Childhood exposure to segregation and long-run criminal behavior: Evidence from the "whole of Sweden" strategy, SOFI Working paper.

Hammarstedt, M. and Shukur, G. (2007), Immigrants' relative earnings in Sweden - a quantile regression approach, International Journal of Manpower, 28, 456-473.

https://doi.org/10.1108/01437720710819992

Holmlund, H. (2015), Education and equality of opportunity: What have we learned from educational reforms?", Nordic Economic Policy Review, 2, 135-1.

Holmlund, H. Häggblom, J. Lindahl, E. Martinsson, S. Sjögren, A. Vikman, U. and Öckert, B. (2014), Decentralisering, skolval och fristående skolor: Resultat och likvärdighet i svensk skola, IFAU Rapport 2014:25.

Jakobsen, V. and Smith, N. (2006), The educational attainment of the children of the Danish "guest worker" immigrants", Danish Journal of Economics, 144(2), 18-42.

le Grand, C. and Szulkin, R. (2002), Permanent disadvantage or gradual integration: explaining the immigrant-native earnings gap in Sweden, Labour, 16, 37-64. https://doi.org/10.1111/14679914.00186

Lundh, C. (2005), "Invandringen till Sverige", SNS förlag, Stockholm. 
Nekby, L. (2002), Employment convergence of immigrants and natives in Sweden, Department of Economics, Stockholm University, Working Paper 2002:9.

Niknami, S. (2014), Intergenerational transmission of education among immigrant mothers and their daughters in Sweden", Review of the Economics of the Household, 14, 715-744.

Riphahn, R. (2003), Cohort effects in the educational attainment of second generation immigrants in Germany: An analysis of census data", Journal of Population Economics, 16(4), 711-737.

Schneeweis, N. (2011), Educational institutions and the integration of migrants. Journal of Population Economics, 24(4), 1281-1308. https://doi.org/10.1007/s00148-009-0271-6

Schnepf, S. (2007), Immigrants' educational disadvantage: an examination across ten countries and three surveys, Journal of Population Economics, 20(3), 527-545. https://doi.org/10.1007/s00148-006-0102-y

Skolverket (2009), Vad påverkar resultaten i svensk grundskola? Kunskapsöversikt om betydelsen av olika faktorer, Rapport.

Skolverket (2016), "Invandringens betydelse för skolresultaten", Rapport.

Van Ours, J. and Veenman, J. (2006), Age at immigration and educational attainment of young immigrants, Economic Letters, 90(3), 310-316. https://doi.org/10.1016/j.econlet.2005.08.013

Van den Berg, G. Pinger, P. and Schoch, J. (2016), Instrumental variable estimation of the causal effect of hunger early in life on health later in life, Economic Journal, 126, 465-506. https://doi.org/10.1111/ecoj.12250

Vlachos, J. (2010), Betygets värde: En analys av hur konkurrens påverkar betygssättningen vid svenska skolor, Konkurrensverket, Rapport.

Wind Fallesen, H. (2015), The educational performance of immigrant children: Examination of the native-immigrant education gap, Working paper 97, The Rockwool Foundation Research Unit. 


\title{
6. Does reduced cash benefit worsen educational outcomes of refugee children? ${ }^{70}$
}

Kristian Thor Jakobsen,${ }^{71}$ Nicolai Kaarsen, ${ }^{72}$ Kristine Vasiljeva ${ }^{73}$

\begin{abstract}
In 2002, the Danish government reduced the size of cash transfers to new refugees. We exploit the reform to study the effect of lower transfers on the educational outcomes of refugee children. First and foremost, the reduction in parental benefits has no negative effect on educational outcomes of the children, such as test scores, probability of completing the gth grade or probability of enrolment in upper-secondary education. Likewise, the children of refugees affected by the reform do not work more in their youth to compensate for lower family income.
\end{abstract}

- Keywords: Integration, refugee children, benefits to refugees.

- JEL: $\mathrm{F}_{22}, \mathrm{H}_{52}, \mathrm{D} 69$.

\footnotetext{
70 We would like to thank participants in the Copenhagen Education Network meeting in spring 2016, Olof Åslund, participants in NEPR seminar on Labour Market Integration in the Nordic Countries in autumn 2016 and three anonymous referees for their valuable comments and suggestions. We also thank Alexander Karlsson and Katrine Bonde for invaluable research assistance.

${ }^{11}$ Den Sociale Kapitalfond Management ApS, Vester Voldgade 108, 1.th., 1552 København V, Denmark.

E-mail: ktj@socialkapitalfond.dk

${ }^{72}$ Kraka, Kompagnistræde 20A, 3. sal 1208 København K, Denmark. E-mail: nk@kraka.org

73 Kraka, Kompagnistræde 20A, 3. sal 1208 København K, Denmark. E-mail: kri@kraka.org
} 


\subsection{Introduction}

More than 0.5 million individuals have sought asylum in Scandinavian countries since the beginning of the Syrian Civil War in 2011. 178,000 of those were children. ${ }^{74}$ To limit the burden of refugee inflow on public finances, the Danish government introduced the so-called integration benefit which in effect reduced the unemployment benefit given to refugees by approximately $40 \%$ in September, 2015.75

This paper analyses whether lower unemployment benefits for refugee parents have an adverse impact on integration of their children, reflected in educational attainment. Our identification relies on the Danish Start Help reform (in Danish: Starthjælp) of 2002. ${ }^{76}$ All refugees arriving before the reform were entitled to the cash benefit (in Danish: Kontanthjælp), whereas those arriving just after the reform received the reduced cash benefit called Start Help, without any exemptions.

There are to our knowledge no studies that identify the effect of lower parental unemployment benefits on the educational outcomes of refugee children. A related Scandinavian literature investigating the effect of parental income on children's educational outcomes in the entire population yields mixed findings. While Humlum (2011) and Loeken (2010) find no effect of parental income on children's achievements, Aakvik et al. (2005) find some evidence that parental income in early life years matters for the child's education. Loeken et al. (2012) find that parental income affects children's achievements in Norway in the poorest families.77

A reduction in parents' benefits can have both a negative and a positive impact on their children's performance. Parents who remain unemployed experience a lower income level potentially leading to lower human capital investments and thus worse

\footnotetext{
74 Statistics for April, 2011 - November, 2016, Eurostat|migr_asyappctzm.

75 The exact size of the reduction varies somewhat with the number of children in the family, age of the parents etc. The $40 \%$ reduction holds for a family consisting of two parents, both older than 30 years, with children. Source:

http://bm.dk/da/Aktuelt/Pressemeddelelser/Arkiv/2015/07/Straksindgreb\%20paa\%2oasylomraadet\%20\%2ony\%2ointegrat ionsydelse\%2otil\%2onytilkomne\%2oudlaendinge.aspx

${ }^{76}$ The Danish Start Help scheme was abolished again in 2012 whereby unemployment benefits for refugees returned to the pre-Start Help level. However, low benefits were re-introduced in 2015 with the integration benefit reform.

77 American studies often establish a positive link between parental income and children's achievements, explained mostly by wealthier parents being able to invest more in their children's education (e.g. Acemoglu and Pischke 2001, Dahl and Lochner 2012, Oreopoulos et al. 2008). However, the education system in Scandinavia is aimed at more equality, providing all children with free education. This is also reflected in correlations in family earnings being much weaker in Scandinavia than in the U.S., suggesting that parental characteristics and income have a more limited impact on the outcomes of children in Scandinavia than in the United States (Björklund et al. 2002, Corak 2006, Schnitzlein 2014, Eurostat 2015).
} 
school outcomes of their children. Thus, poorer parents may be forced to live in areas with cheaper housing and lower quality schools. This could have ramifications for educational outcomes, since the evidence from Christoffersen and Larsen (2016) indicates that there is a considerable variation in schooling quality in Denmark. Low income could also be an obstacle for enrolling in a private school..$^{8}$ Kaarsen and Vasiljeva (2016) show that immigrant children from private Muslim schools perform better in national tests than immigrant children of the same origin from other schools, despite the socioeconomic background of pupils in Muslim schools is weaker. Moreover, socially disadvantaged parents in Denmark are found to spend less on their children's leisure activities and learning aids (Bonke 2009, Nielsen et al. 2012, Benjaminsen et al. 2016), which could likewise affect children's performance negatively. There could also be an effect through labour supply of the children. If they choose to work more in response to lower parental income either to compensate for a lower amount of pocket money or to help the parents, it could have a negative impact on learning.

On the contrary, for families where parents find a job due to facing lower benefits there could be a positive effect. This effect could stem from an increase in income resulting in larger human capital investments, or from social skills, language proficiency, values and norms that parents pick up on their job and pass on to their children. ${ }^{79}$ From a policy perspective, the effect of lower unemployment benefits is relevant since benefits is a popular tool used to regulate income of disadvantaged families. ${ }^{80}$

Our results show no systematic difference in test scores between children whose parents received the full cash benefit and those whose parents were entitled to the lower Start Help benefit. There is likewise no statistically significant difference in school completion or enrolment in upper-secondary education between the two groups of refugee children. Furthermore, we find no support for the hypothesis that children in

\footnotetext{
${ }^{78} \mathrm{~A}$ survey from 2012 shows that the average fee for attending a private school is 1,500 DKK per child per month which amounts to around 1,300 DKK in 2005. (Politiken 2012). This corresponds to around $5 \%$ of the average yearly gross household income in our sample the first three years after the residence permit was granted. Thus, parents would have to pay a non-negligible share of their income to send their children to private school.

79 For instance, Dahl et al (2014) find that there is a causal impact of parents receiving welfare on the probability of children receiving welfare. They argue that this reflects a cultural transmission of norms and values associated with welfare reception.

${ }^{80}$ Like the re-introduction of reduced benefit to refugees in Denmark in September, 2015.
} 
families affected by the reform worked more in their youth to compensate for lower parental income. Consequently, at least in a Scandinavian setting where both compulsory and upper-secondary education is free, lowering unemployment benefits to refugee parents is not a detriment to their children's educational outcomes.

\subsection{Policy background}

The Start Help benefit was introduced from the 1st of July, 2002. Its goal was to reduce unemployment benefits to immigrants. It was aimed at non-EU/EEA immigrants who had lived less than seven out of the past eight years in Denmark, thus mostly affecting recently arrived refugees and their families. ${ }^{81}$ The new benefit was 36 to $48 \%$ lower than the cash benefit received by refugee families who arrived before the 1st of July, 2002. The exact magnitude of the reduction depended on the number of children and adults in the household, as shown in Table 1. Families would receive lower transfers if at least one of the parents arrived after the 1st of July, 2002. The benefit was administered by, but did not depend on, the municipality of residence, and it was not means tested..$^{82}$ Refugees were eligible for the lower amount for the first seven years of residence in Denmark, after which they were eligible for the full cash benefit amount.

Table 1: Examples of Yearly Amount in DKK of the cash benefit versus the Start Help Benefit

\begin{tabular}{|c|c|c|c|}
\hline Household type & The cash benefit & The Start Help benefit & Reduction in \% \\
\hline One adult, no children & 98,064 & 63,192 & 35.5 \\
\hline One adult + one child & 130,308 & 78,996 & 39.4 \\
\hline Two adults, no children & 196,128 & 104,784 & 46.6 \\
\hline Two adults + one child & 228,372 & 117,888 & 48.4 \\
\hline
\end{tabular}

Note: Adult above 25. Source: https://www.retsinformation.dk/Forms/Ro710.aspx?id=29615

Previous research has shown that employment of refugees has increased in response to the cut in benefits (Rosholm and Vejlin 2010, Andersen et al. 2012). However, the increase in employment income could not compensate for the fall in benefits. While benefits received by refugees over the first three years in the country fell by around

\footnotetext{
${ }^{81}$ Danish citizens were also subject to the reform.

${ }^{82}$ https://www.retsinformation.dk/Forms/Ro710.aspx?id=9043
} 
240,000 DKK, labour income rose only by around 90,000 DKK. The growth in labour income was modest as the share of families with at least one parent in job increased by approximately 10 percentage points, as shown in Figure $4 \mathrm{a}$ in the appendix. Consequently, the total income of refugee parents over the first three years in the country fell on average by about $14 \%$ compared to the income of those arriving just before, cf. Figure $1 .{ }^{83}$

Figure 1: Accumulated Parental Income Over 3 Years since Immigration

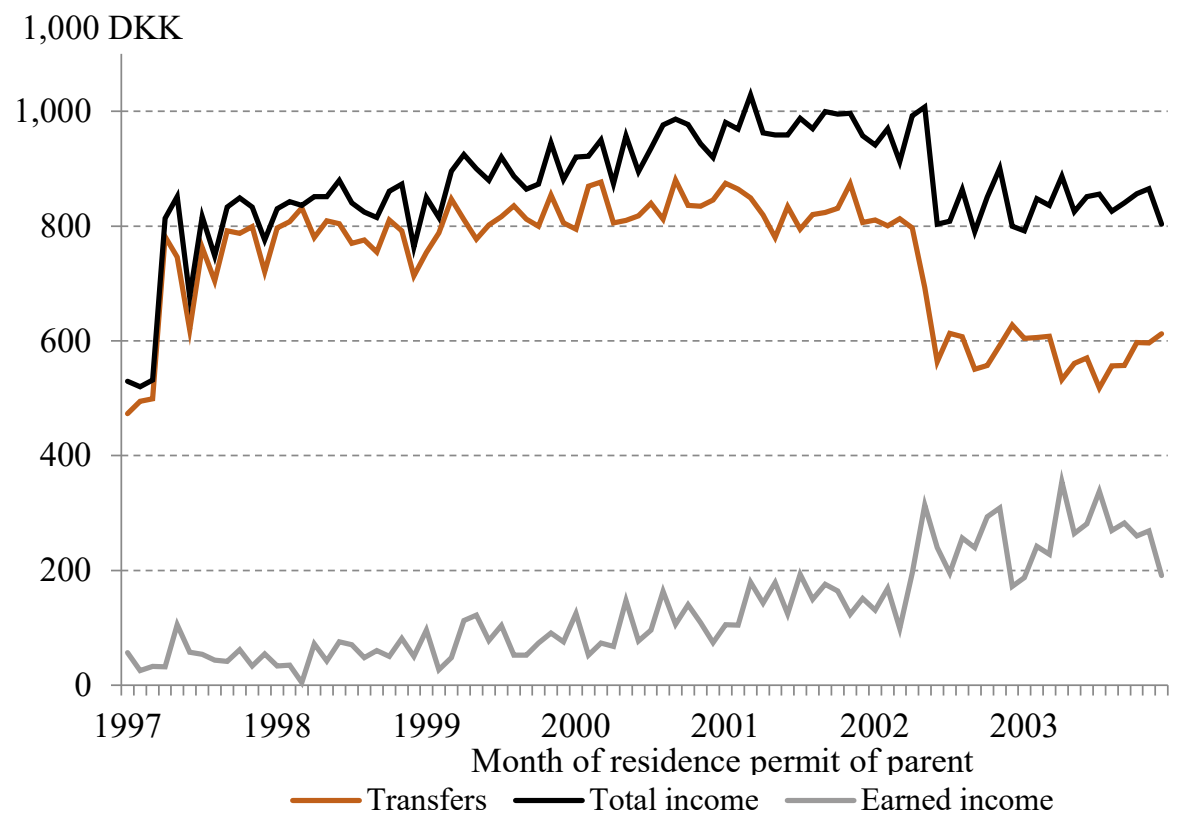

Besides the Start Help reform, the rules of family reunification were tightened from the 1st of July, 2002. ${ }^{84}$ The stricter rules, however, did not apply if the applicant living in Denmark was a refugee who could not return to his or her home country due to the risk

\footnotetext{
$8_{3}$ The fraction of the families with no labour income was approximately 10 percentage points lower in the group arriving after reform. The income gap between the two groups ceased to exist after 7 years of residence in Denmark, when refugees receiving the Start Help benefit were again entitled to receive the full cash benefit, as shown in Figure $2 a$ in the appendix. ${ }^{84} \mathrm{After}$ the family reunification reform, both adults had to be at least 24 years to be entitled for reunification. Furthermore, the spouse living in Denmark had to have a bank account with savings of at least 50,000 DKK, suitable accommodation, and a year prior to the unification where he or she did not receive any public transfers.
} 
of persecution. The reform thus primarily affected labour immigrants or refugees who filed for reunification many years after they arrived in Denmark where the war in their home country had ended and they could return safely. ${ }^{85}$ The data supports the notion that the reunification reform did not affect our sample: In the control group, the fraction of children whose parents were reunified is $82.6 \%$, in the treatment group it is slightly lower at $81.0 \%$, but the difference is statistically insignificant.

\subsection{Data}

The data are from the Danish Administrative Registers owned by Statistics Denmark. We select 4,829 refugee children whose second parent received residence permit in Denmark during the period between the 1st of May, 2001 and the 31st of June, 2003 which is one year on each side of the reform cut-off, as shown in Figure 2 below. ${ }^{86}$

Figure 2: Treatment and control groups

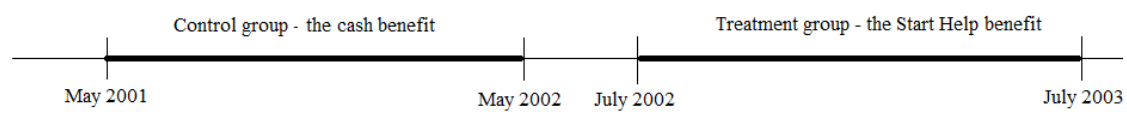

Children whose second parent arrived the year before the 1st of May, 2002 were unaffected by the reform and constitute the control group. Children whose parents arrived up to a year after the 3oth of June, 2002 were affected by the reform and constitute the treatment group. We exclude children whose second parent arrived in May and June, 2002, as it could take up to two months to find housing and move the refugee from the asylum centre to the municipality of placement. Therefore, parents who were granted a residence permit two months before the 1st of July, 2002 could be already

\footnotetext{
85 If the refugee's spouse and children lived in another country, it was evaluated whether it is safe for the family to live in that country. If not the exemption also applied.

86 If there is only one parent, that parent's date of being granted residence permit is used.
} 
affected by the reform. ${ }^{87}$ We use the date of residence of the second parent since this determines whether the family receives the high or the low amount of transfers. ${ }^{88}$

Information about the type and the date of the residence permit to refugees and family reunited is available in the administrative register on the purpose of residence, whereas the children of refugees can be identified using the population register. Children are defined as individuals who are less than 18 years old at the date of the residence permit of the second parent. We exclude unaccompanied refugee children.

We collect information about the educational and labour market outcomes of the children such as grade point average in the gth grade tests (at the completion of lowersecondary school), participation rate in tests in Danish and Mathematics, completion of compulsory school, enrolment in upper-secondary education and employment and labour market earnings, when the child is between 13 and 17 (inclusive) years old. ${ }^{89}$ We focus on participation in Danish and Mathematics tests, as all pupils had to be tested in these two subjects in all school completion years we observe. $9^{\circ}$

The latest year where data on most educational outcomes is available is 2013. We would like to observe the children's outcomes when they are at least 17 years old in 2013 , since the typical school completion age in Denmark is 16 years, and we allow for one additional year for refugee children. It means that the children who immigrated last in our sample in 2003 are at least 7 years old at the arrival, see Figure 3. Children who are younger than 7 years at arrival in 2003 are also younger than 17 years in 2013 and therefore their schooling outcomes are unknown. For labour market outcomes, we likewise restrict the minimum age to be 7 years to be able to observe their income when they are $13-17$ years old.

\footnotetext{
87 Another possibility is to use data on the date of arrival to the municipality of placement instead of the date of residence permit. However, we choose not to do so for two reasons. Firstly, the data on date of arrival at the municipality is more imprecise. Secondly, the municipality could potentially delay the placement of certain refugees thus selecting who are in the treatment and control groups.

88 In the remainder of the paper we use the terms "the date of the second parent's residence permit" and "the arrival date" interchangeably.

${ }^{89} 13$ years is the legal working age in Denmark for children.

90 Participation in other subjects was determined randomly.
} 
Figure 3: Observation window for children's outcomes

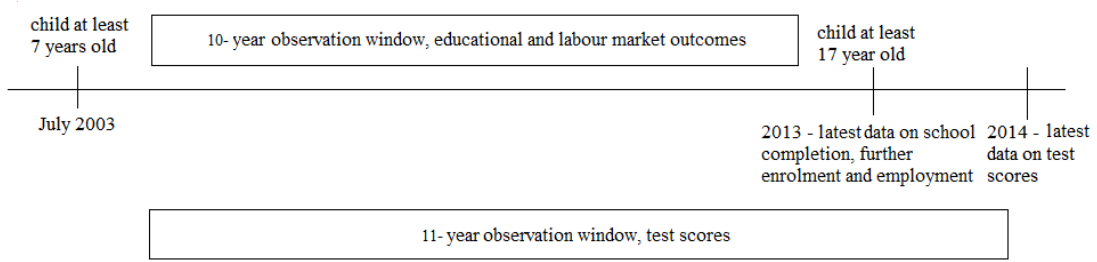

We observe outcomes of children who arrived at different dates for an equal number of years, since the probability of completing compulsory school or enrolling in an uppersecondary education by construction increases with years since arrival. Children in the control group have arrived to Denmark earlier, so without this restriction they would have higher completion rates by construction since they would have a year more to finish school. Our observation window is restricted to 10 years, because the latest arrival dates are in 2003 and the data on school completion and further enrolment ends in 2013. When it comes to test scores, the latest year of data is 2014 so here we use an 11-year window. Our effective sample consists of 3,016 refugee children for which we can observe school completion. ${ }^{91} 2,015$ of these have data on test participation, and 1,913 on test scores.

We also collect demographic information which includes age at arrival, gender, origin, whether the children have only one parent in Denmark, and whether the children have left the country at some point after the outcome was observed. Likewise, we obtain information on parental education at arrival collected by Statistics Denmark to control for parental human capital in the regressions. Parental education is selfreported and the length of education at various stages can vary across countries. Therefore, instead of computing a continuous measure such as years of schooling, we defined a binary variable for whether one or both parents have completed at least upper-secondary education..$^{92}$ The summary statistics for the variables are presented in Table 1a of appendix.

$9^{1}$ The sample size for children's labour outcomes is reduced to 2,829 individuals. The income of the children arriving at 17 years of age are first observed in the income register when they turn 18 and therefore they are not included in the sample. $9^{2}$ Statistics Denmark impute missing education data for some refugees. We recode all imputed data to missing. 


\subsection{Methodology and identification}

We compare the outcomes of children whose parents were granted a residence permit within a year before the reform to the outcomes of children whose parents were granted a residence permit within a year after the reform. This is done by estimating a model for the children's outcomes using OLS, with the main explanatory variable being a binary indicator for whether the second parent was granted a residence permit after the reform cut-off date. An extended model adds controls for the demographic background of the child, parental education, year of exam fixed effects, the date of residence permit and age of the child at the date the residence permit was granted. The last-mentioned variable captures time trends in outcomes.

We argue that refugee parents' skills could not affect whether they received the cash benefit or the Start Help benefit, thus allowing us to estimate the effect of change in parental benefits on child outcomes. The Start Help reform was implemented over a very short time, so most of the refugees in our sample did not learn about the reform before they arrived to Denmark. The reform discussions were raised by a Danish centreright government which was formed at the end of November, 2001.93 The official legislation was signed in June, 2002 and became effective shortly after, on the 1st of July, 2002. To the best of our knowledge there was no change in the asylum procedure, so the individual cases would be processed in the order they were received. Consequently, it is highly unlikely that refugees, who were more skilled and aware of international politics, could systematically obtain residence permit before the reform. ${ }^{94,} 95$ Figure $3 \mathrm{a}$ in the appendix shows furthermore, that there was no clustering of refugee arrivals around the reform date.

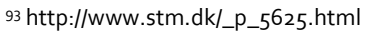

94 Moreover, the largest part of refugee flows was driven by the need for safety, rather than economic motives, as 20012003 was a period of wars in Afghanistan, Iraq, Somalia and former Yugoslavia.

${ }_{95}$ Asylum cases in Denmark took around 10 months to process at the time of the reform (Danish Immigration Service 2003).
} 


\begin{tabular}{lrrrr} 
& Control & Treatment & Difference & P-value \\
Age at arrival & & & & 0.013 \\
Female & 11.914 & 11.900 & -0.006 & 0.904 \\
Only 1 parent & 0.447 & 0.453 & 0.018 & 0.740 \\
Migrated out & 0.045 & 0.027 & 0.045 & 0.016 \\
Skilled father & 0.182 & 0.137 & 0.194 & 0.000 \\
Skilled mother & 0.415 & 0.211 & 0.023 & 0.098 \\
From Afghanistan & 0.170 & 0.147 & 0.276 & 0.000 \\
From Iraq & 0.446 & 0.170 & -0.173 & 0.000 \\
From Somalia & 0.351 & 0.524 & -0.009 & 0.488 \\
Observations & 0.095 & 0.103 & & \\
\hline
\end{tabular}

Note: Children whose parents arrived as refugees or family-reunified to refugees. Control group: The second parent arrived in the period from the 1st of May, 2001 to the 30 th of April, 2002. Treatment group: The second parent arrived in the period from the 1st of July, 2002 to the $30 t h$ of June, 2003. The last three rows list the fraction of refugee children from the three largest source-countries

Table 2 compares characteristics of the children and their parents in control and treatment groups. Age and gender appear to be well balanced between the two groups. There are though considerable differences in ethnic composition: Afghans are overrepresented in the control group, whereas Iraqis are overrepresented in the treatment group. The changes in ethnic composition of refugees were caused by political events, such as the Afghan Civil War in 1996-2001 and the Iraq War in 20022003, and thus not related to the Danish Start Help reform. It is, however, still important to control for the country of origin, since it could be correlated with school performance. ${ }^{96}$

Parents who arrived before the reform were more likely to have at least an uppersecondary education. This is to a considerable extend driven by differences in country of origin: Fathers from Afghanistan were more likely to report that they have at least an upper-secondary education than fathers from Iraq. Therefore, it is also important to control for parental education in the regressions. But what if controls for parental education do not fully capture parental human capital, but are positively correlated with unobserved ability? In this case, parents arriving before the cut-off have higher ability, which would bias the estimate of the effect of the reform in a negative direction.

\footnotetext{
${ }^{96}$ As a robustness check, we exclude individuals from Afghanistan and Somalia. The main conclusions are unaffected, see
} Table $2 a$ in the appendix. 
Our main finding is that the reform had no effect, so a negative bias would imply that the real effect is positive. This further strengthens our conclusion that lowering unemployment benefits does not have a detrimental effect on educational outcomes of refugee children. ${ }^{97}$

\subsection{Results}

We begin by evaluating the impact the Start Help reform had on the average score in the gth grade school completion tests. This is the first indicator of how well the refugee children integrate in Denmark and what their chances are to obtain further education and find employment as adults. Figure 4 a shows that the difference between the average test score of children who arrived before and after the reform cut-off is close to zero, it is also statistically insignificant, cf. Figure $4 \mathrm{~b}$. The conclusion is the same when control variables and year of exam fixed effects are introduced, cf. Table $2 a$ in the appendix..$^{8}$

Controlling for gender shows that females obtain a higher grade, as shown in Table 2a. The coefficient on age at date of residence permit is negative, indicating that children who were younger when they arrived to Denmark, and thus have had more years to learn the language and culture, get higher grades. The coefficient on date of residence permit of the parents is insignificant. This is reassuring since it suggests that when our set of controls are included, there are no systematic changes in the composition of refugees over time affecting the educational achievement. We include a dummy for outmigration to capture any potential effects on migration choice associated with the reform. The year of exam could affect the grade, since tests questions change from year to year. We control for year of exam fixed effects to remove variation in test scores due to differences in test difficulty.

We also include several controls capturing the characteristics of the parents, as shown in Table $2 a$ in the appendix. The coefficient on single parent is insignificant. To

\footnotetext{
${ }_{97}$ Single-parent children are overrepresented in the control group by construction. Families with the second parent arriving after the cut-off are assigned to the treatment group, so there are more two-parent families in that group. Single-parent children typically underperform (see e.g. Mulkey et al. 1992 or Downey 1994). To avoid a positive bias of the estimate of the effect of the reform, we control for a single-parent dummy.

${ }^{9}$ For the results where control variables are introduced in the regression on one-at-a-time basis please see the technical paper by Jakobsen et al. (2016).
} 
control for the educational level of the parents, we include two dummies that capture, respectively, whether the mother and father has any education beyond the secondary school. The coefficients on both dummies are highly significant suggesting that there is a link between parental human capital and human capital of the children. The country of origin also matters to educational success. Refugee children from Afghanistan have higher grades than refugees from Iraq and Somalia. Refugees from Afghanistan, Iraq and Somalia constitute $85 \%$ of our sample. The omitted category is all other countries.

Figure 4a: Main results, levels

Grade average 05
04
04
03
03
02
02
01
01
00

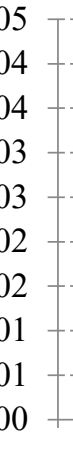

Average exam grade (left axis)

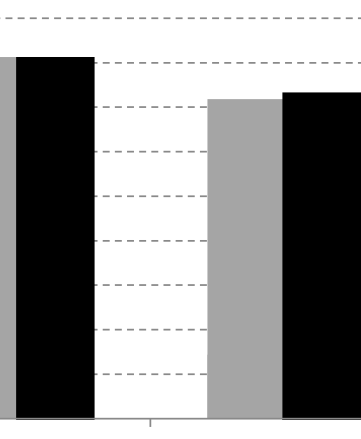

Finished 9th grade (right axis)

Control
Pct. 90 80 70 60 50 40 30 20 10 0
Started education Child income $>0$ (right beyond 9th grade (right axis) axis)

- Treatment 
Figure 4 b: Main results, differences and statistical significance

Grade average

Pct. point

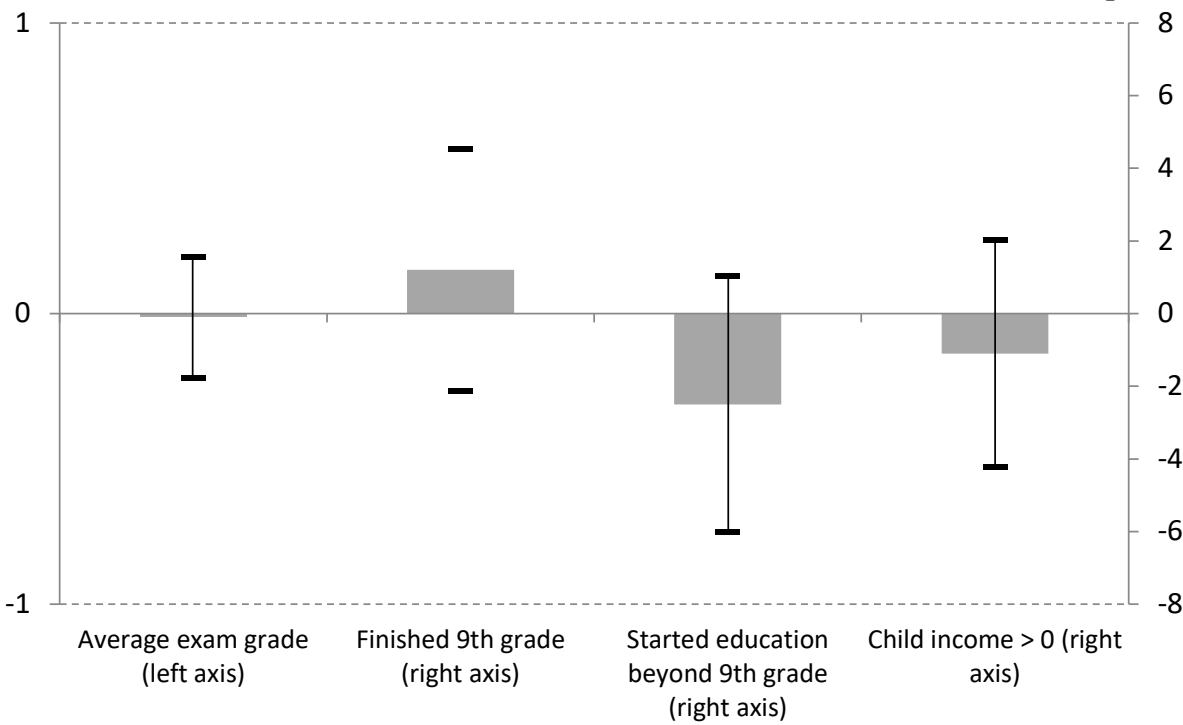

Note: Difference calculated between individuals receiving the Start Help benefit and the cash benefit. $95 \%$ confidence intervals, based on estimates for standard errors in Table $2 a$ and Table $3 a$.

Table $4 \mathrm{a}$ in the appendix conducts several robustness checks confirming that the reform did not have any impact on test scores. First, we control for a full set of sourcecountry fixed effects. Second, we exclude refugees from Afghanistan and Iraq, the two largest source countries in our sample. The third and fourth robustness checks include, respectively, refugees from Afghanistan and Iraq. Interestingly, the coefficient turns positive and significant when only Afghan refugees are included, however, there are no significant effects on the other educational outcomes. There are 1,398 Afghan children in the control group, but only 247 Afghan children in the treatment group. The large drop reflects the de-escalation of the conflict in Afghanistan, and it seems likely that this entailed a change in the composition of refugees which coincides with the reform. Reassuringly, the main results are not changed when excluding only Afghan children 
from the sample. ${ }^{99}$ The fifth robustness check includes only refugees who got a residence permit 6 months before and 6 months after the reform cut-off dates, excluding those who arrived 6-12 months before and after. ${ }^{100}$ Focusing on the period just before and after the reform could ensure that the two groups are more similar in terms of unobserved characteristics. The sixth robustness check focuses on refugees who arrived between 6-12 months before and after the reform cut-off dates. This limits the possibility of selection in two ways. Firstly, refugees who arrived more than 6 months before the cut-off had no possibility to learn about the reform as its discussion had just begun. Secondly, it limits the potential selection that could arise if the processing of cases for certain groups of refugees was hastened just around the reform. Restricting the sample period does not alter our conclusions about the impact of reduction in benefits on children's test scores. In the seventh robustness check children's outcomes are observed only during the first seven years since the arrival, as parents were maximally affected by the reform during the first seven years in Denmark. Again, this does not alter our conclusions.

We also investigate the effect of lower unemployment benefits on other educational indicators. There is no significant effect of reduction in the benefit on the probability of starting upper-secondary school or the likelihood of finishing gth grade, cf. Figure $4 \mathrm{~b}$. The insignificance of the probability of starting upper-secondary is worth emphasizing as one would expect that any permanent and robust effects on the educational achievements of refugee children would be reflected here. Table $4 \mathrm{a}$ in the appendix also shows that the treatment dummy is significantly and negatively correlated with the likelihood of attending Danish exams and insignificantly correlated with the likelihood of attending math exams. The significant difference in the likelihood of attending Danish exams becomes insignificant in most of the robustness checks.

Besides the main educational outcomes, we also evaluate whether the reduction in benefits has increased child labour supply to compensate for lower parental

\footnotetext{
99 Results are available upon request. In the robustness checks presented in the paper we exclude refugees from both Afghanistan and Iraq, as the flow of refugees from Iraq increase simultaneously with the decline in the number of refugees from Afghanistan.

${ }^{100}$ As in the baseline specification, the reform cut-off dates are 1st of July, 2002 and 1st of May, 2002, respectively. Thus, we exclude refugees who arrived two months before the reform. As explained above, the date the refugees were placed in the municipality of residence determines whether they were affected by the reform. Since it could take up to two months for the refugees to be placed in their municipality of residence, some of the refugees who arrived during the two months before 1st of July were affected by the reform and some were not.
} 
income. We compute the average yearly income the child earns while being 13 to 17 years old. ${ }^{101,102}$ The age thresholds correspond, respectively, to the minimum working age in Denmark, and the age at which most children have finished primary school. Figure $4 \mathrm{a}$ and Figure $4 \mathrm{~b}$ show that there is no relationship between the reform and whether children work in their youth. As shown in Table 4a, this finding is robust to including a full set of host country dummies and changing the sample. This is consistent with our main conclusion that the reform had a limited effect on school outcomes. The conclusion is similar if the indicator for positive labour income is replaced with other indicators of labour supply. In particular, we compute average labour income and two dummies indicating whether the yearly income exceeds 6,000 and $12,000 \mathrm{kr}$. respectively, see Table $3 a$ in the appendix. Thus, the reform did not seem to affect the labour supply of the refugee children.

\subsection{Conclusion}

We investigate the effect of a decline in the size of public transfers to refugee parents on the educational outcomes of their children caused by the Start Help reform of refugee benefits in 2002. Refugees who arrived after the reform cut-off received reduced benefits. Short reform timing excluded to a large degree the possibility of predicting the reform and avoiding it, thus preventing self-selection among refugees into the group eligible for high benefits. We compare the children of parents who arrived before and to those who arrived after the reform cut-off. We do not find any statistically significant difference in the gth grade national tests scores, school completion probability or probability of enrolling in an upper-secondary education. We find some suggestive evidence that children affected by the reform were less likely to take all parts of Danish language test, but this result is not robust.

\footnotetext{
${ }^{101}$ Investigating the effect of lower benefits on earned income of children is only relevant if there is ample variation in the left-hand-side variable, that is, if some of the children supply a non-negligible amount of labour. 2,256 out of the 2,829 children have a positive average income. 1,470 children earn more than DKK 6,000 per year, and 938 or about one third of the children earn more than DKK 12,000. According to Statistics Denmark (2017) the average hourly wage of teens below 18 was around DKK 70 in the mid 2000's. At that wage, DKK 12,000 pr. year corresponds to 3.3 hours pr. week. This indicates that it is not uncommon for the teenagers in our sample to work, and it suggests that it indeed is sensible to investigate the consequences of the reform for the labour supply of children.

${ }^{102}$ For children arriving to Denmark after they turn 13 and before they turn 17, the average yearly income is calculated for those years for which the child is in the country till the child turns 18.
} 
The fact that the Start Help reform has not affected educational outcomes of refugee children can potentially be explained by the reduction of benefits leading to two effects that counteract each other. The first effect is the income effect. Lower parental income is expected to lead to lower investments in child's education and worsening of educational outcomes. The second effect is the employment effect of incentivizing parents to find a job which works in the opposite direction. Parental employment can improve children's educational outcomes, for instance, through transmission of culture, language skills or norms. The positive effect of employment could counterbalance the negative income effect leading to no overall impact of benefit reduction on children's outcomes. Alternatively, it is possible that in Scandinavian setup parental income does not play an important role for child's education, as argued by a related study by Humlum (2011).

To our knowledge there are no other papers investigating the effect of lower unemployment transfers on educational outcomes of children which could shed more light on the relative importance of income versus employment effect. A study by Loeken et al (2012) use a regional oil shock as the source of exogenous increase in income. However, in case of an oil shock, the income and employment effect go in the same direction, since the shock increases the relative benefit of employment by raising labour income. ${ }^{103}$ They find that higher income increases educational success for children of poor families, whereas the average effect across all families is zero. ${ }^{104}$ They do not discuss the relative importance of the employment effect and the income effect. Another source of the discrepancy between our results and those of Loeken et al (2012) is that the population, country, and period differ. Loeken et al (2012) investigate children of Norwegians who grew up in the 1970's. We focus on refugee children who grew up in Denmark in the 2000's, for whom the positive effect of parental integration by finding a job can be particularly large due to the transmission of language and cultural values.

Further research should try to isolate the effects of changes in parental income on children's educational outcomes from the impact of changes in employment. Isolating the income effect would help to understand whether an employment effect counteracts a possible negative income effect. This could be done by studying

${ }^{103}$ The oil shock did not affect benefits or public expenditures locally.

${ }^{104}$ Loeken (2010) likewise finds that the average effect of an income increase due to the oil shock is o. 
households where the parents are not able to change their labour supply in response to a change in benefits.

\section{References}

Aakvik, A., Salvanes, K. G. and Vaage, K. (2005), Educational attainment and family background, German Economic Review 6(3), 377-394. https://doi.org/10.1111/j.14680475.2005.00138.x

Acemoglu, D. and Pischke, J.-S. (2001), Changes in the wage structure, family income, and children's education, European Economic Review 45(4-6), 890-904. https://doi.org/10.1016/S0014-2921(01)00115-5

Andersen, H. L., Schultz-Nielsen, M. L., Hansen, H. and Tranaes, T. (2012), Starthjaelpens betydning for flygtninges levevilkaar og beskaeftigelse [The importance of Start Help for refugees' living standards and employment], Rockwool Foundation Research Unit Working Paper (25), 1-54.

Benjaminsen, L., Enemark, M. H. and Birkelund, J. F. (2016), Fattigdom og afsavn [Poverty and deprivation], SFI.

Björklund, A., Eriksson, T., Jäntti, M., Raaum, O. and Sterbacka, E. (2002), Brother correlations in earnings in Denmark, Finland, Norway and Sweden compared to the United States, Journal of Population Economics 15(4), 757-772. https://doi.org/10.1007/s001480100095

Bonke, J. (2009), Forældres brug af tid og penge på deres børn [Parental use of time and money on their children], Odense: Rockwool Fondens Forskningsenhed og Syddansk Universitetsforlag.

Christoffersen, H. and Larsen, K. B. (2016), Penge og præstationer - indsigter fra Undervisningsministeriets 2016 data for grundskolen [Money and performance - insights from the data for lower-secondary school of Danish Ministry of Education 2016], CEPOS Working Paper, 15-09-2016.

Corak, M. (2006), Do poor children become poor adults? Lessons from a cross country comparison of generational earnings mobility, IZA Discussion Paper (1997).

Dahl, G. B. and Lochner, L. (2012), The impact of family income on child achievement: Evidence from the earned income tax credit, American Economic Review 102(5), 19271956. https://doi.org/10.1257/aer.102.5.1927

Dahl, G. B., Kostøl, A. R., and Mogstad. M. (2014), Family Welfare Cultures, Quarterly Journal of Economics 129(4), 1711-1752. https://doi.org/10.1093/qje/qju019

Danish Immigration Service (2003), Nøgletal på udlændingeområdet 2003 [Key Figures on Immigration].

Downey, D. B. (1994), The school performance of children from single-mother and single-father families: Economic or interpersonal deprivation?, Journal of Family Issues 15(1), 129-147. https://doi.org/10.1177/019251394015001006 
Eurostat, (2015), Intergenerational transmission of disadvantage statistics. URL:

http://goo.gl/ytQnTt

Humlum, M. K. (2011), Timing of family income, borrowing constraints, and child achievement, Journal of Population Economics 24(3), 979-1004. https://doi.org/10.1007/s00148-010-0309-9

Jakobsen, K. T., Kaarsen N., and Vasiljeva, K. (2016), Does reduced cash benefit worsen educational outcomes of refugee children? MPRA Working Paper.

Kaarsen, N. and Vasiljeva, K. (2016), Børn fra muslimske friskoler - hvordan klarer de sig? [Children from private Muslim schools - how do they perform?], http://kraka.org/analyse/boern_fra_muslimske_friskoler_hvordan_klarer_de_sig

Loeken, K. V. (2010), Family income and children's education: Using the Norwegian oil boom as a natural experiment, Labour Economics 17(1), 118-129. https://doi.org/10.1016/j.labeco.2009.06.002

Loeken, K. V., Mogstad, M. and Wiswall, M. (2012), What linear estimators miss: The effects of family income on child outcomes, American Economic Journal: Applied Economics 4(2), 1-35.

Mulkey, L. M., Crain, R. L. and Harrington, A. J. C. (1992), One-parent households and achievement: Economic and behavioral explanations of a small effect, Sociology of Education 65(1), 48-65. https://doi.org/10.2307/2112692

Nielsen, G., Grønfeldt V., Toftegaard-Støckel, J. and Andersen , L.B. (2012), Predisposed to participate? The influence of family socio-economic background on children's sports participation and daily amount of physical activity, Sports in Society, 15(1), 1-27. https://doi.org/10.1080/03031853.2011.625271

Oreopoulos, P., Page, M. and Stevens, A. H. (2008), The intergenerational effects of worker displacement, Journal of Labor Economics 26(3), 455-483. https://doi.org/10.1086/588493

Politiken (2012), Privatskoler er rørende billige [Private schools are ridiculously cheap]. Retrieved from www.politiken.dk.

Rosholm, M. and Vejlin, R. (2010), Reducing income transfers to refugee immigrants: Does start-help help you start?, Labour Economics 17(1), 258-275. https://doi.org/10.1016/j.labeco.2009.09.004

Schnitzlein, D. D. (2014), How important is the family? Evidence from sibling correlations in permanent earnings in the USA, Germany, and Denmark, Journal of Population Economics 27(1), 69-89. https://doi.org/10.1007/s00148-013-0468-6

Statistics Denmark (2017). Hourly wages for private employees, Table LONo5X from www.statistikbanken.dk. Accessed 1/2-2017. 


\section{Appendix}

\section{Supplementary Figures}

Figure 1a: Parental Income in the 8th Year since Immigration

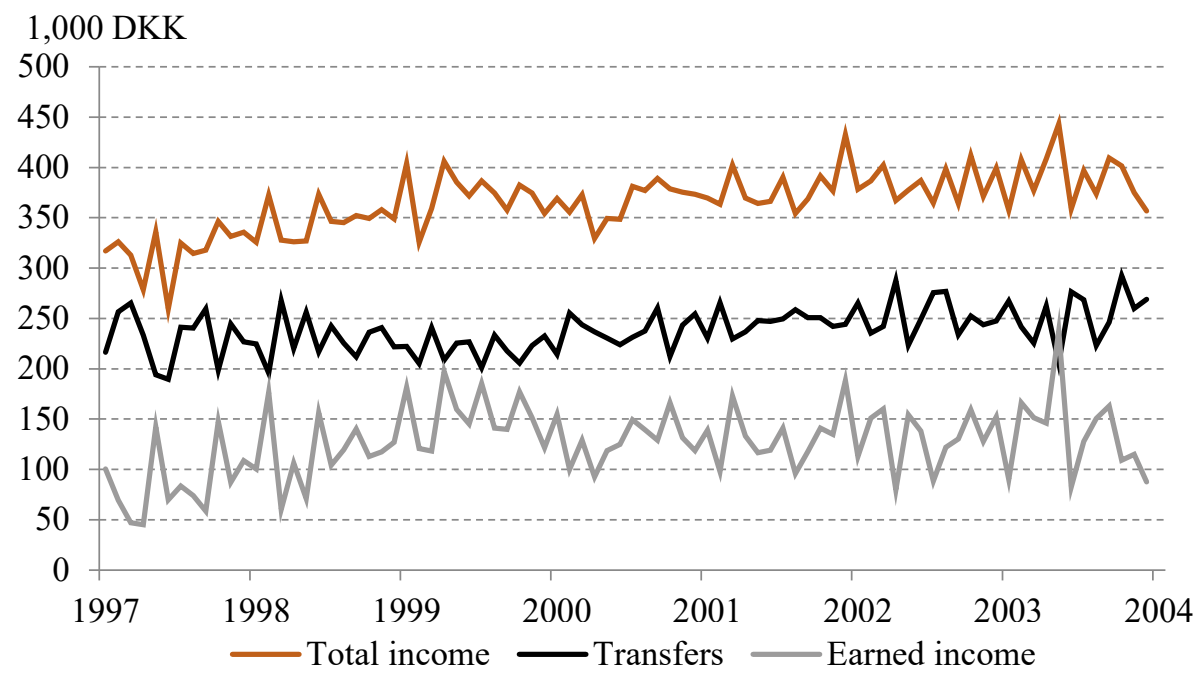


Figure 2a: Number of children distributed by parent's residence permit date

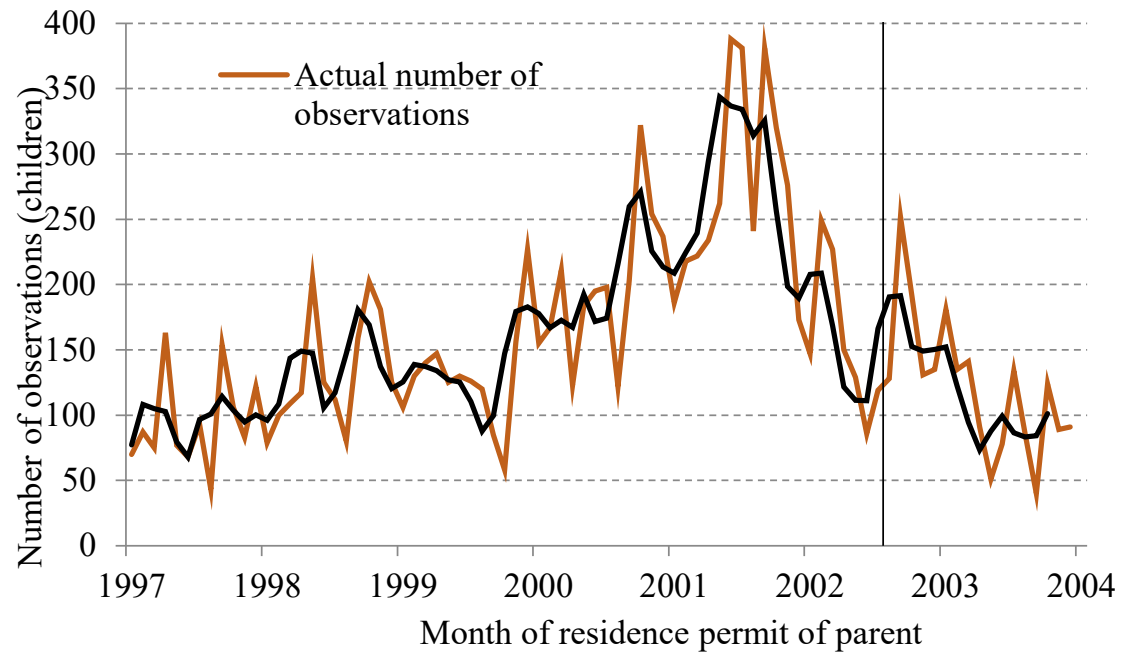

Figure 3a: Distribution of the sum of earned income of the parents the first three years after entry in 1,000 of DKK

Pct.

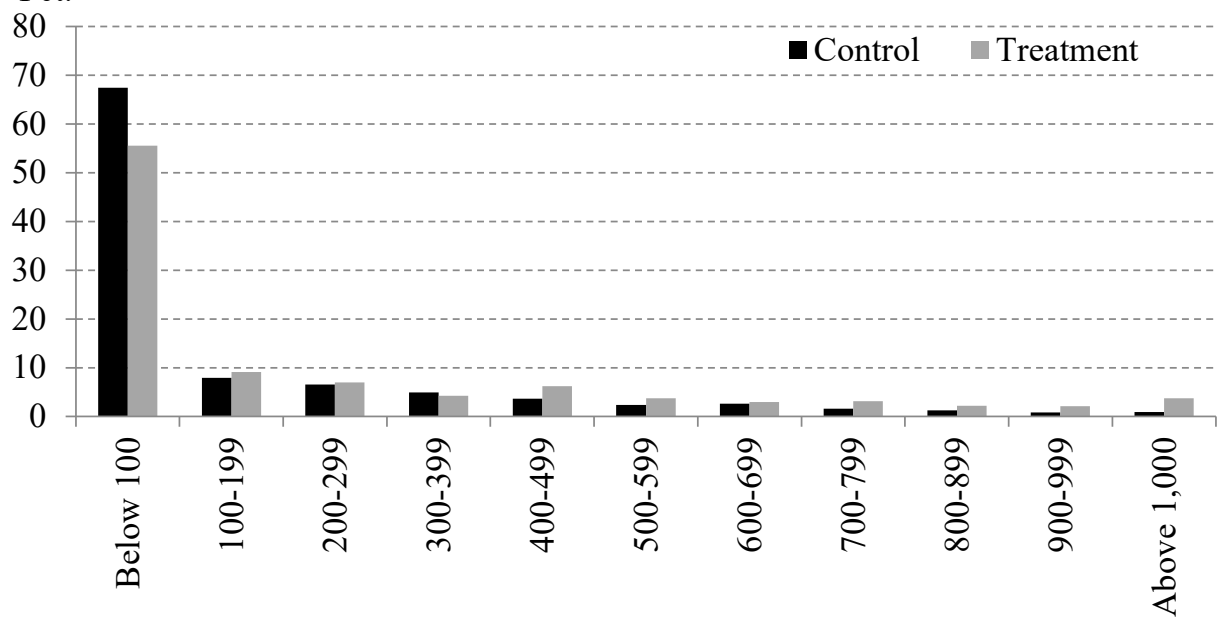

Note: Incomes above 1 mio. DKK are excluded to comply with the data confidentiality policy of Statistics Denmark. 


\section{Supplementary Tables}

Table 1a: Descriptive Statistics

\begin{tabular}{lccc} 
Mean & Mean & Standard deviation & Observations \\
Average exam grade & 4.28 & 2.25 & 2,310 \\
Took all Danish tests & 0.88 & 0.32 & 2,412 \\
Took all Mathematics tests & 0.91 & 0.28 & 2,412 \\
Finished gth grade & 0.47 & 0.50 & 4,829 \\
Started education beyond gth grade & 0.44 & 0.50 & 4,829 \\
Average child income & 9.77 & 10.92 & 2,829 \\
Transfers & 738.90 & 264.40 & 4,829 \\
Earned income & 186.43 & 298.26 & 4,829 \\
Total income & 925.33 & 270.31 & 4,829 \\
Employment rate & 0.10 & 0.12 & 4,181 \\
Average exam grade - Danish & 4.04 & 2.12 & 2,218 \\
Average exam grade - math & 4.34 & 2.89 & 2,235 \\
Age at arrival & 9.09 & 4.43 & 4,828 \\
Female & 0.47 & 0.50 & 4,829 \\
Only 1 parent & 0.04 & 0.19 & 4,829 \\
Migrated out & 0.15 & 0.36 & 4,829 \\
Skilled father & 0.35 & 0.48 & 4,829 \\
Skilled mother & 0.16 & 0.37 & 4,829 \\
\hline
\end{tabular}

Note: Children whose parents arrived as refugees or family-reunified to refugees in the period from the 1st of May, 2001 to the 30 th of April, 2002 or the 1st of July, 2002 to the zoth of June, 2003. Only children who are 7 years or older at date of residence permit are included. Exam grades are observed in an 11-year window starting from the date of residence permit. Other outcomes are observed in a 10-year window starting from the date of residence permit. Effective sample size is 3,016 refugee children. 2,015 of these have data on exam attendance and 1,913 have obtained all grades in exams. Child earned income is observed at ages 13 to 17 and is based on 2,829 children who arrived to Denmark before they turned 17.

Table 2a: Main results

\begin{tabular}{|c|c|c|c|c|c|c|c|c|c|c|}
\hline & \multicolumn{2}{|c|}{$\begin{array}{l}\text { Average exam } \\
\text { grade }\end{array}$} & \multicolumn{2}{|c|}{$\begin{array}{l}\text { Took all Danish } \\
\text { exams }\end{array}$} & \multicolumn{2}{|c|}{ Took all math exams } & \multicolumn{2}{|c|}{ Finished gth grade } & \multicolumn{2}{|c|}{$\begin{array}{l}\text { Started upper- } \\
\text { secondary }\end{array}$} \\
\hline & (1) & (2) & (3) & (4) & (5) & (6) & (7) & (8) & (9) & (10) \\
\hline Treatment & $\begin{array}{r}-0.013 \\
(0.106)\end{array}$ & $\begin{array}{r}0.280 \\
(0.228)\end{array}$ & $\begin{array}{r}-0.059 * * * \\
(0.017)\end{array}$ & $\begin{array}{l}-0.074^{*} \\
(0.036)\end{array}$ & $\begin{array}{r}-0.009 \\
(0.014)\end{array}$ & $\begin{array}{l}-0.060 \\
(0.031)\end{array}$ & $\begin{array}{r}0.012 \\
(0.017)\end{array}$ & $\begin{array}{r}0.060 \\
(0.038)\end{array}$ & $\begin{array}{l}-0.025 \\
(0.018)\end{array}$ & $\begin{array}{r}-0.027 \\
(0.040)\end{array}$ \\
\hline Female & & $\begin{array}{r}0.407^{* * *} \\
(0.092)\end{array}$ & & $\begin{array}{r}0.046 * * \\
(0.014)\end{array}$ & & $\begin{array}{r}0.014 \\
(0.013)\end{array}$ & & $\begin{array}{r}0.021 \\
(0.015)\end{array}$ & & $\begin{array}{r}0.009 \\
(0.016)\end{array}$ \\
\hline
\end{tabular}




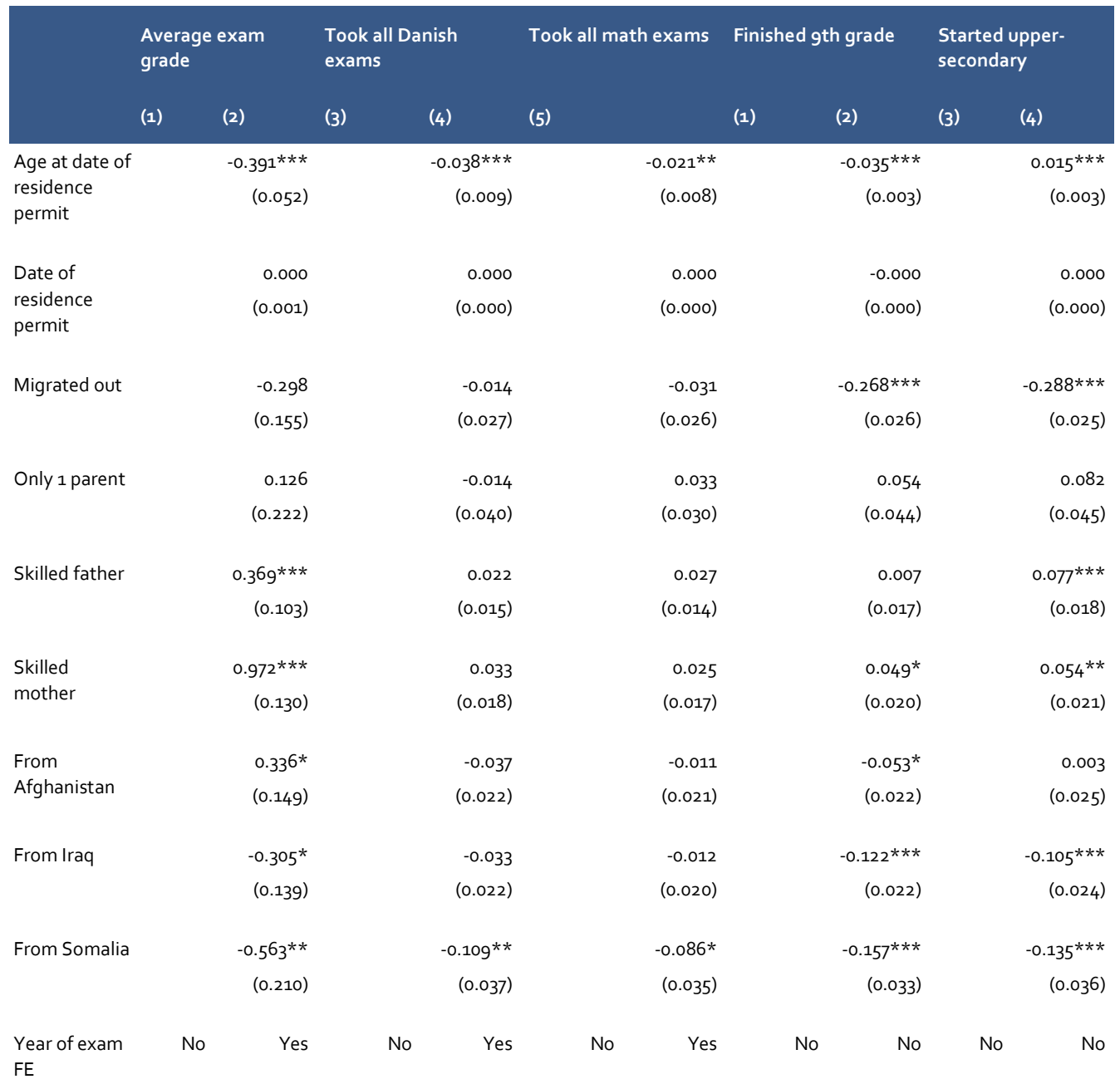




\begin{tabular}{|c|c|c|c|c|c|c|c|c|c|}
\hline & \multicolumn{2}{|c|}{$\begin{array}{l}\text { Average exam } \\
\text { grade }\end{array}$} & \multicolumn{2}{|l|}{$\begin{array}{l}\text { Took all Danish } \\
\text { exams }\end{array}$} & Took all math exams & \multicolumn{2}{|c|}{ Finished gth grade } & \multicolumn{2}{|c|}{$\begin{array}{l}\text { Started upper- } \\
\text { secondary }\end{array}$} \\
\hline & (1) & (2) & (3) & & (5) & (1) & (2) & (3) & (4) \\
\hline Observations & 1913 & 1913 & 2015 & 2015 & 2015 & 3016 & 3016 & 3016 & 3016 \\
\hline R-squared & 0.000 & 0.164 & 0.007 & 0.124 & 0.000 & 0.000 & 0.130 & 0.001 & 0.098 \\
\hline
\end{tabular}

Note: Children whose parents arrived as refugees or family-reunified to refugees. Control group: The second parent got a residence permit in the period from the 1st of May, 2001 to the 30 th of April, 2002. Treatment group: The second parent got a residence permit in the period from the 1st of July, 2002 to the 30 th of June, 2003. Only children who are 7 years or older at arrival are included. Exam grades are observed in an 11-year window since the date of residence permit. Other outcomes are observed in a 10-year window since the date of residence permit. Heteroscedasticity robust standard errors. ${ }^{*} p<0.05, * * p<0.01, * * * p<0.001$. Effective sample size is 3,016 refugee children. There can be observed the attendance of tests for 2,015 of these have data on exam attendance, and 1,913 have obtained all grades in exams

Table за: Earning and employment of refugee children

\begin{tabular}{|c|c|c|c|c|c|c|c|c|}
\hline & \multicolumn{2}{|c|}{$\begin{array}{l}\text { Child earned } \\
\text { income }\end{array}$} & \multicolumn{2}{|c|}{$\begin{array}{c}\text { Child earned income }> \\
0\end{array}$} & \multicolumn{2}{|c|}{$\begin{array}{c}\text { Child earned income }> \\
6,000\end{array}$} & \multicolumn{2}{|c|}{$\begin{array}{c}\text { Child earned income }> \\
12,000\end{array}$} \\
\hline & (1) & (2) & (3) & (4) & (5) & (6) & (7) & (8) \\
\hline \multirow[t]{2}{*}{ Treatment } & -0.436 & 0.374 & -0.011 & 0.040 & $-0.040 *$ & -0.006 & -0.018 & 0.009 \\
\hline & $(0.432)$ & $(0.934)$ & $(0.016)$ & $(0.034)$ & $(0.020)$ & $(0.042)$ & (0.019) & $(0.041)$ \\
\hline \multirow[t]{2}{*}{ Female } & & $-3.978 * * *$ & & $-0.146 * * *$ & & $-0.164 * * *$ & & $-0.142 * * *$ \\
\hline & & $(0.376)$ & & (0.015) & & $(0.018)$ & & $(0.017)$ \\
\hline \multirow[t]{2}{*}{ Age at date of residence permit } & & $0.175^{*}$ & & $-0.015^{* * *}$ & & 0.002 & & $0.008 *$ \\
\hline & & $(0.075)$ & & $(0.003)$ & & (0.003) & & $(0.003)$ \\
\hline \multirow[t]{2}{*}{ Date of residence permit } & & 0.002 & & -0.000 & & 0.000 & & 0.000 \\
\hline & & $(0.002)$ & & $(0.000)$ & & $(0.000)$ & & $(0.000)$ \\
\hline \multirow[t]{2}{*}{ Migrated out } & & $-3.515 * * *$ & & $-0.241 * * *$ & & $-0.158 * * *$ & & $-0.098 * * *$ \\
\hline & & $(0.461)$ & & $(0.025)$ & & $(0.024)$ & & $(0.021)$ \\
\hline \multirow[t]{2}{*}{ Only 1 parent } & & 1.512 & & 0.074 & & 0.066 & & $0.104 *$ \\
\hline & & $(0.922)$ & & $(0.038)$ & & $(0.047)$ & & $(0.045)$ \\
\hline
\end{tabular}




\begin{tabular}{|c|c|c|c|c|c|c|c|c|}
\hline & \multicolumn{2}{|c|}{$\begin{array}{l}\text { Child earned } \\
\text { income }\end{array}$} & \multicolumn{2}{|c|}{$\begin{array}{c}\text { Child earned income }> \\
0\end{array}$} & \multicolumn{2}{|c|}{$\begin{array}{c}\text { Child earned income }> \\
6,000\end{array}$} & \multicolumn{2}{|c|}{$\begin{array}{c}\text { Child earned income }> \\
\qquad 12,000\end{array}$} \\
\hline & (1) & (2) & (3) & (4) & & (1) & (2) & (3) \\
\hline \multirow[t]{2}{*}{ Skilled father } & & $1.289 * *$ & & $0.047^{* *}$ & & $0.077^{* * *}$ & & $0.060 * *$ \\
\hline & & $(0.449)$ & & $(0.015)$ & & $(0.020)$ & & (0.019) \\
\hline \multirow[t]{2}{*}{ Skilled mother } & & 0.476 & & 0.014 & & 0.019 & & 0.029 \\
\hline & & $(0.581)$ & & (0.019) & & $(0.025)$ & & $(0.025)$ \\
\hline \multirow[t]{2}{*}{ From Afghanistan } & & $4.733^{* * *}$ & & $0.058 * *$ & & $0.166 * * *$ & & $0.183^{* * *}$ \\
\hline & & $(0.604)$ & & $(0.022)$ & & $(0.030)$ & & $(0.029)$ \\
\hline \multirow[t]{2}{*}{ From Iraq } & & -0.794 & & $-0.085^{* * *}$ & & $-0.085^{* *}$ & & $-0.065^{*}$ \\
\hline & & $(0.540)$ & & $(0.022)$ & & $(0.029)$ & & $(0.026)$ \\
\hline \multirow[t]{2}{*}{ From Somalia } & & $-3.866 * * *$ & & $-0.146 * * *$ & & $-0.250 * * *$ & & $-0.180 * * *$ \\
\hline & & $(0.634)$ & & $(0.034)$ & & $(0.036)$ & & $(0.030)$ \\
\hline Observations & 2829 & 2829 & 2829 & 2829 & 2829 & 2829 & 2829 & 2829 \\
\hline R-squared & 0.000 & 0.140 & 0.000 & 0.148 & 0.001 & 0.141 & 0.000 & 0.119 \\
\hline
\end{tabular}

Note: Children whose parents arrived as refugees or family-reunified to refugees. Control group: The second parent got a residence permit in the period from the 1st of May, 2001 to the 30 th of April, 2002. Treatment group: The second parent got a residence permit in the period from the 1st of July, 2002 to the 30 th of June, 2003. Only children who are 7 years or older at arrival are included. Only earned income at ages 13 to 17 observed in a 10-year window since the date of residence permit are included. Effective sample size is 3,016 refugee children, where child earned income is based on 2,829 children who arrived to Denmark before they turned 17. Heteroscedasticity robust standard errors. ${ }^{*} p<0.05, * * p<0.01, * * * p<0.001$.

Table 4a: Robustness Checks

\begin{tabular}{|c|c|c|c|c|c|c|}
\hline & $\begin{array}{r}\text { Average } \\
\text { exam grade }\end{array}$ & $\begin{array}{r}\text { Took all } \\
\text { Danish } \\
\text { exams }\end{array}$ & $\begin{array}{r}\text { Took all } \\
\text { math exams }\end{array}$ & $\begin{array}{r}\text { Finished } 9 \\
\text { th grade }\end{array}$ & $\begin{array}{r}\text { Started } \\
\text { upper- } \\
\text { secondary }\end{array}$ & $\begin{array}{r}\text { Child } \\
\text { earned } \\
\text { income }\end{array}$ \\
\hline & (1) & (2) & (3) & (4) & (5) & (6) \\
\hline \multicolumn{7}{|c|}{ Panel a: Country of origin fixed effects } \\
\hline \multirow[t]{2}{*}{ Treatment } & 0.407 & $-0.077^{*}$ & $-0.066 *$ & 0.064 & -0.024 & 0.823 \\
\hline & $(0.233)$ & $(0.038)$ & $(0.033)$ & $(0.039)$ & $(0.041)$ & $(0.947)$ \\
\hline Year of exam FE & Yes & Yes & Yes & No & No & No \\
\hline Control variables & Yes & Yes & Yes & Yes & Yes & Yes \\
\hline Observations & 1913 & 2015 & 2015 & 3016 & 3016 & 2829 \\
\hline R-squared & 0.199 & 0.135 & 0.107 & 0.142 & 0.113 & 0.154 \\
\hline
\end{tabular}




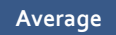 \\ exam grade
}

Took all

Danish

exams
Took all Finished 9
th grade

upper-

Child

(1)

(2)

(3)

(4)

secondary

earned

income

Panel b: Excluding refugees from Afghanistan and Iraq

Treatment

-0.550
$(0.463)$
Yes
Yes
424
0.199

$-0.130$

$-0.086$

$-0.014$

(0.065)

(0.068)

Yes

Yes

Year of exam FE

Control variables

0.199

Yes

Observations

R-squared

449

0.138

Yes

449

0.155

$-0.063$

(0.067)

(0.453)

Yes

Yes

Control variables

769

Observations

0.155

Yes

Yes

803

0.156

$$
\begin{array}{r}
0.006 \\
(0.059) \\
\text { Yes } \\
\text { Yes } \\
803 \\
0.105
\end{array}
$$

\begin{abstract}
$-0.048$
\end{abstract}
$-0.042$

(0.056)

(0.346)

Yes

Year of exam FE

Control variables

Yes

Yes

(0.047)

Yes

Yes

763

0.114

0.136

0.191

763

R-squared

$-0.066$

0.009

$-0.000$

(0.052)

Yes

Yes

Yes

Yes

Yes

874

0.169

0.147

874

0.130

No

Yes

719

0.230

(5)

R-squared

Panel $\mathrm{f}$ : Exclude refugees who arrived 6 months before and 6 months after the reform cut-off dates

$\begin{array}{lrrrr}\text { Treatment, 6 months away } & 1.444^{*} & -0.081 & -0.018 & -0.136 \\ \text { from cut-off } & (0.667) & (0.101) & (0.090) & (0.117) \\ \text { Year of exam FE } & \text { Yes } & \text { Yes } & \text { Yes } & \text { No } \\ \text { Control variables } & \text { Yes } & \text { Yes } & \text { Yes } & \text { Yes } \\ \text { Observations } & 1014 & 1059 & 1059 & 1529 \\ \text { R-squared } & 0.172 & 0.143 & 0.102 & 0.108\end{array}$

\section{(10)}

0.095

(0.073)

No

Yes

1058

0.093

$\begin{array}{rr}-0.027 & -1.247 \\ (0.075) & (1.499) \\ \text { No } & \text { No } \\ \text { Yes } & \text { Yes } \\ 719 & 680 \\ 0.143 & 0.134\end{array}$

0.143

.134

$\begin{array}{rr}-0.025 & 0.946 \\ (0.069) & (2.103) \\ \text { No } & \text { No } \\ \text { Yes } & \text { Yes } \\ 1058 & 1014 \\ 0.073 & 0.060\end{array}$

$0.017 \quad 1.848$

(0.065) (1.429)

No No

Yes Yes

$1239 \quad 1135$

$0.082 \quad 0.085$

$0.048 \quad-0.161$

(0.069) (1.550)

No No

Yes Yes

$1364 \quad 1265$

$0.128 \quad 0.136$

$\begin{array}{ll}-0.176 & -5.709\end{array}$

(0.121) (2.982)

No No

Yes Yes

$1529 \quad 1440$

$0.083 \quad 0.156$ 


\begin{tabular}{|c|c|c|c|c|c|c|}
\hline & $\begin{array}{r}\text { Average } \\
\text { exam grade }\end{array}$ & $\begin{array}{c}\text { Took all } \\
\text { Danish } \\
\text { exams }\end{array}$ & $\begin{array}{r}\text { Took all } \\
\text { math exams }\end{array}$ & $\begin{array}{r}\text { Finished } 9 \\
\text { th grade }\end{array}$ & $\begin{array}{r}\text { Started } \\
\text { upper- } \\
\text { secondary }\end{array}$ & $\begin{array}{r}\text { Child } \\
\text { earned } \\
\text { income }\end{array}$ \\
\hline & (1) & (2) & (3) & (4) & (5) & (6) \\
\hline \multicolumn{7}{|c|}{ Panel i: Only outcomes within seven years of arrival } \\
\hline Treatment & $\begin{array}{r}0.147 \\
(0.295)\end{array}$ & $\begin{array}{c}-0.101 * \\
(0.047)\end{array}$ & $\begin{array}{l}-0.063 \\
(0.042)\end{array}$ & $\begin{array}{r}0.040 \\
(0.044)\end{array}$ & $\begin{array}{r}-0.023 \\
(0.040)\end{array}$ & $\begin{array}{r}290.411 \\
(930.640)\end{array}$ \\
\hline Year of exam FE & Yes & Yes & Yes & No & No & No \\
\hline Control variables & Yes & Yes & Yes & Yes & Yes & Yes \\
\hline Observations & 1105 & 1492 & 1492 & 3016 & 3016 & 2829 \\
\hline R-squared & 0.144 & 0.120 & 0.087 & 0.073 & 0.209 & 0.144 \\
\hline
\end{tabular}

Note: Children whose parents arrived as refugees or family-reunified to refugees. Control group: The second parent got a residence permit in the period from the 1st of May, 2001 to the 30 th of April, 2002. Treatment group: The second parent got a residence permit in the period from the 1st of July, 2002 to the 30 th of June, 2003. Only children who are 7 years or older at arrival are included. Exam grades are observed in an 11-year window since the date of residence permit. Other outcomes are observed in a 10-year window since the date of residence permit. Effective sample size is 3,016 refugee children. There can be observed the attendance of tests for 2,015 of them and 1,913 have obtained all grades in exams. Child earned income is observed at ages 13 to 17 and is based on 2,829 children who arrived to Denmark before they turned 17 . Heteroscedasticity robust standard errors. ${ }^{*} p<0.05, * * p<0.01, * * * p<0.001$. 


\title{
7. The fiscal impact of refugee immigration
}

Joakim Ruist ${ }^{105}$

\begin{abstract}
This paper summarizes the state of knowledge about how refugee immigration affects public finances in the receiving country. I first review the contextual background for this research, including the public demand for it and methodological and ethical considerations. Many studies estimate the fiscal impact of immigration, but few focus on more specific immigrant groups, such as refugees. There exist two studies that estimate the fiscal impact of refugee immigration using Swedish data. I report their results in some detail. They show that refugee immigration implies a noticeable burden on public finances both in the short and the long run, yet far from to the extent where the fiscal sustainability of modern welfare systems would be threatened. These results also imply that it would be financially sustainable for the European Union as a whole to increase its refugee admittance by several million people over a few years.
\end{abstract}

- Keywords: immigration; public finances; refugees.

- JEL codes: $\mathrm{H}_{20}, \mathrm{H}_{50}, \mathrm{~J}_{19}, \mathrm{~J} 61$

105 University of Gothenburg, joakim.ruist@economics.gu.se 


\subsection{What, and why, do we want to know?}

This article summarizes what is known about the impact of refugee immigration on public finances. I first review the contextual background for this research, including the public demand for it and methodological and ethical considerations. I then report the results from existing studies with a specific focus on refugee immigration, or whose results can be interpreted in that direction.

Questions regarding the fiscal effects of immigration have been of major interest for a long time in many Western countries, to scholars and the public alike. Individual studies of these effects have been conducted in most Western countries. The OECD (2013) recently conducted a large-scale study covering all its member countries. In the major Nordic immigration country Sweden, reports have been produced quite regularly for more than 40 years.

Public interest in these studies is substantially higher than in most other economic research. They make newspaper headlines, have wide non-academic readership, and are subject to long and detailed discussions in Internet forums. Also compared with other topics relating to immigration, the fiscal impact appears to be of greater public concern. People appear to be more concerned about the risk of immigrants increasing their tax burden than taking their jobs. ${ }^{106}$

Where does this large public interest originate, and to what extent can we see it as justified? In general, there is indeed probably more reason to be concerned about the impact of immigration on the tax burden than on the labor market. If immigration harms previous residents' employment or wages, it is only likely to do so for a relatively short time. There is a multitude of factors through which the labor market may adjust to "neutralize" the inflow over time. This is quite obvious if we consider the simple fact that countries with larger populations do not automatically have lower wages or employment rates, because with larger populations they have also acquired correspondingly more of other factors of production. Furthermore, any harmful labor market impact is likely to be less important for the types of immigration that have been most salient in public debate in the Nordic countries over the last decade. For the Eastern European immigration this is so because this immigration was quite strongly demand-driven and hence concentrated to sectors with worker shortage. For the

\footnotetext{
${ }^{106}$ See the appendix to Pinotti, forthcoming, for this empirical result in several Western countries.
} 
refugee immigration this is so because of the long time it takes most refugees to find employment; the economy has ample time to adjust to their presence before they get their first jobs.

The fiscal impact of immigration on the other hand, whether positive or negative, need not be similarly neutralized over time. An inflow of immigrants that find employment increases the country's employment rate - and hence its per-capita tax base - for as long as they remain employed. Similarly, an inflow of immigrants that do not find employment lowers the per-capita tax base as long as they remain unemployed. Hence fiscal effects may be long-lasting.

Yet sometimes the high level of public interest in the fiscal impact of immigration appears to represent not so much a genuine desire for knowledge, as a desire to collect arguments for one's position on a heated and often emotionally debated topic. The desire for supportive economic arguments appears to be strong on both sides of the immigration debate, plausibly because these may claim to represent objective truths in a way that is more difficult for value-based arguments. Not seldom this wish even trumps the normal sense of quality control. Having reached the point of despair at the aggressive public rhetoric against immigration from Romania and Bulgaria in early 2014, media from all across Europe reported my finding (Ruist, 2014a) of a positive fiscal impact of this immigration with something like a unified sigh of relief. Not in one instance did any of them ask a critical question or make any attempt at quality control. More generally, "Immigration has cost/earned this country X billion" makes a powerful and popular newspaper headline, in spite of being quite uninformative e.g. when neither the headline nor the ensuing article reports over how many years immigration and the cost respectively were measured (especially since in many instances these two numbers are different). This also creates scope for more or less overt abuse. Actors in both the Swedish pro- and anti-immigration camps have in recent years produced and publicly communicated their own "research results", which have indicated fascinating fiscal gains and losses respectively from immigration. Yet these have been based on scant and carefully selected data to produce the signs in line with the writers' agendas. Eventually they were also summed over multiple years, increasing the magnitudes of the estimated effects and hence the power of the ensuing newspaper headlines.

Research on the fiscal impact of immigration should be seen in this context. It is easy to produce results that make headlines, and the headline-writers are not much concerned about assessing the quality of the research behind the results. The results will be used by actors with strong, sometimes extreme, policy agendas. It is therefore 
important to ask: What is the usefulness of estimates of the fiscal effects of immigration? Which estimates are more useful than others? Which estimates are precise enough to be of any use? Which are the downsides or risks involved when reporting these estimates, and is it always justified to report them?

In Section 7.2 I try to provide some answers to these questions by outlining the motivation for conducting the research, as well as important methodological issues that affect the interpretation and usefulness of the results, as well as highlight their uncertainty. In Section 7.3 I provide an account of the details of the calculations of the fiscal effects. In Section 7.4 I review in some detail the results of the two existing studies that estimate the fiscal effects of refugee immigration using Swedish data. Section 7.5 concludes.

\subsection{Motivation for and methodological issues in estimating the fiscal impact}

Academic and public interest in the fiscal impact of immigration to a large extent stem from two different sources; one more optimistic and one more pessimistic.

First of these is the fact that the populations of all Western European countries are aging. Aged dependency ratios, i.e. the ratios of above-working-age to working-age individuals, are thus predicted to rise in the future. These predicted rises are comparatively modest in the Scandinavian countries, where fertility in the last decades has been only slightly below the natural replacement rate. Figure 1 shows actual 2015 and predicted 2030 aged dependency ratios in Western Europe. The countries are ordered by the size of the predicted increases. The three Scandinavian countries are found in the left half of the graph, with predicted rises of $4-8$ percentage points. Finland is further to the right at 10 points. Furthest to the right is Germany, where fertility has been low for decades, with a predicted rise of 14 percentage points in these 15 years. 
Figure 1: Aged dependency ratios in Western Europe 2015 and predicted 2030

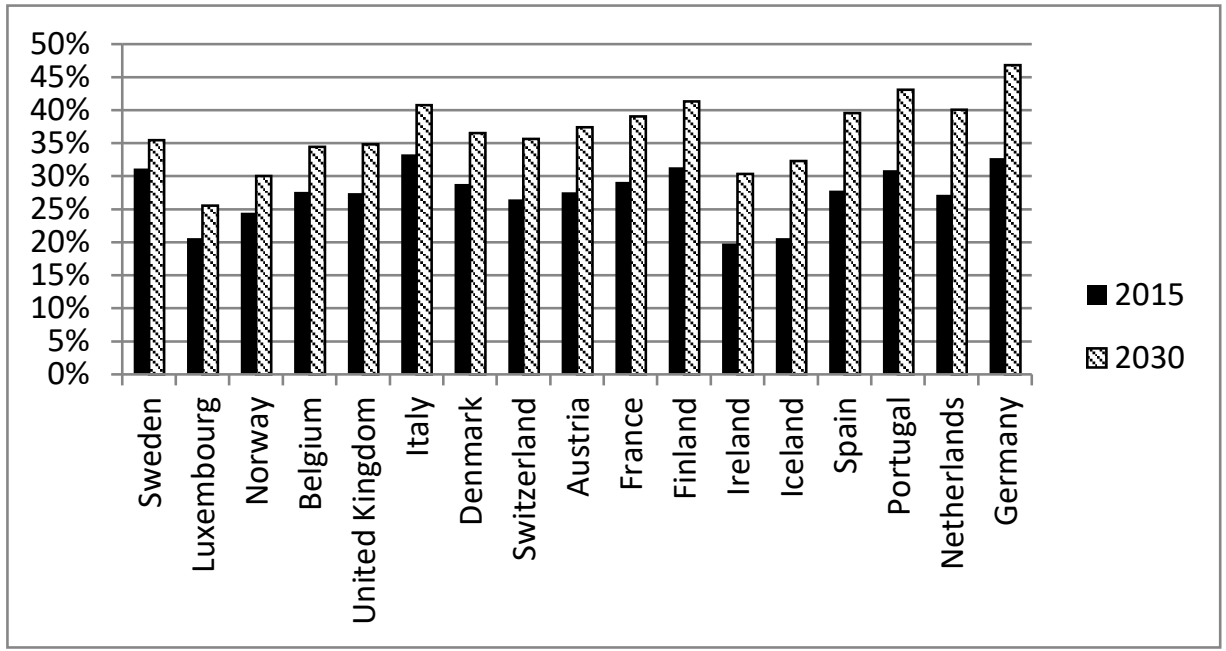

Note: The solid bars show aged dependency ratios in 2015, and the striped show predicted ratios in 2030. Countries are ordered by the size of the gap between the two. Data source and predictions:

Eurostat.

Rising shares of elderly in the population puts additional strain on public finances, since it implies that the number of additional individuals that each working individual supports through their tax payments rises. As the elderly group grows older, the strain increases further with increasing care needs of the group. Among the potential tools for relieving part of this predicted future strain on public finances is immigration. A prominent feature of international migration is that it is strongly dominated by individuals of younger working age, i.e. around 20-35 years of age. Immigration may thus potentially improve public finances, since immigrants typically arrive at the start of the economically productive phase of their lives and the host country did not incur the costs of schooling and subsistence during their childhood. Everything else equal, immigrants will therefore imply net gains for the public finances of the host country, both in the short term after their arrival and over their entire lives.

However everything else is not equal, and the second source of interest in the public finance effects of immigration is instead a concern about the potential negative impact of certain kinds of immigration. If immigrants don't reach high enough employment rates, their impact on public finances may be negative in both the short and the long 
term, in spite of the positive potential in their age structure. In Western Europe, low employment rates are typically a matter of fact for refugee immigrants in particular. Fears of inflows of immigrants with low rates of self-subsistence and hence negative impact on public finances were also prominent at the time of the eastward enlargement of the European Union in 2004 and 2007, which - although with some delay - implied the granting of free movement of workers also to citizens of the lower-income countries of Eastern Europe.

Studies of the public finance impact of immigration may thus have crucial relevance for important policy questions. On the one hand, how much is there potentially to gain for Western societies by seeking to attract more immigration of certain types to mitigate the negative fiscal consequences of population ageing? On the other, is there a need to be cautious about not permitting too large inflows of other types of immigrants, so as to not endanger the economic sustainability of the welfare system? (Or, depending on one's policy preferences: how important changes to the welfare system would we need to do in order to make the immigration possible that we want to have for other - e.g. humanitarian - reasons?)

Yet in spite of their obvious potential relevance, these studies are sometimes criticized on moral grounds. It is said to be unethical to label a (vulnerable) group of people as a cost, or to even measure an important social or humanitarian activity by economic standards. Those of us who disagree with these criticisms can choose to dismiss them based on the obvious truth that when resources are limited - as they always are - no costly activity can expand indefinitely. Yet we can also choose to ask ourselves why these criticisms appear at all in spite of this obvious truth. Part of the answer is probably because the policy stakes are so high. No similar objections are heard e.g. every year when 290 Swedish municipality governments publish their annual costs of elderly care and social assistance, although these estimates can similarly be interpreted as labelling (vulnerable) groups of people as costs. One important difference between this example and immigration is that there is large public consensus behind the laws that govern e.g. social assistance. Hence the probability that someone with an agenda to completely scrap it would be able to use estimates of their fiscal costs to rally much support is small. On the other hand, there is little public consensus on immigration policy. Hence the risk that economic calculations could have important policy effects may be perceived of as more realistic. The ethnic dimension of immigration and our awareness of how negative views of other ethnic groups may lead to extreme outcomes may further enhance the sensitivity. 
Against this background it is important that we who produce this research are able to communicate why this work is important. And I believe that we ourselves deserve part of the blame for the resistance that we sometimes encounter, for not having done this well enough. There are different ways to ask questions about the fiscal effects of immigration. Sometimes we have failed to explain well enough why we ask - and answer - them in the way that we do. Sometimes we may not even have had any good reason. The risk of misinterpretation or abuse of our results is always present, and therefore we need to be selective. We should not investigate everything from every angle simply because we can. We need to make sure that the studies we conduct are indeed useful, that we shape their details in the way that makes them as useful as possible, and finally that we communicate this usefulness to the readers. In the remainder of this section I discuss some issues that are central to this.

\subsubsection{Inferring fiscal effect from fiscal redistribution}

Estimating the true fiscal effect of the presence of an immigrant group is not possible. What the majority of studies do is to calculate the fiscal redistribution between the immigrant group in question and the rest of the population, or in different words, to calculate the net fiscal contribution of the immigrant group. Thus setting equality between fiscal redistribution and fiscal effect implicitly amounts to assuming that the presence of the immigrant group has no dynamic impact at all on the remaining agents in the economy, i.e. that it does not affect their economic behavior or outcomes. This is of course not true. If it was, to take one simple example, it would imply that without the last decades of immigration Sweden would have had a very acute shortage of taxi drivers today. No researcher would claim that this is true. Some are more explicit in their research reports, consistently stating that what they provide is an estimate of the fiscal redistribution, and never mentioning the word effect. However many of us use the word effect, at least to some extent, although we know it is not strictly true. From my viewpoint, this is not to exaggerate the relevance or the reliability of the results. It is a recognition of the fact that while the calculated redistribution is not equal to the true effect, my belief that it is a fair enough proxy for this effect is indeed the very reason why I am calculating it. Henceforth in this text, I will keep using the word effect.

While we can do a fairly good job at listing plausible dynamic mechanisms through which immigration impacts on the economic standing of others, we do not know much about their detailed workings. Hence we often do not even know whether, by ignoring 
them, we bias our results in a positive or negative direction. In the taxi driver example, the concrete question is where we find today the native-born Scandinavians that would have been taxi drivers if immigration had been lower. Are they unemployed, or do they occupy other similarly-paid jobs, or has immigration made e.g. their native language skills relatively more valued and hence allowed them to move "upward" into betterpaid jobs? The true answer is most likely an unknown combination of all three, and we know little about their relative importance. ${ }^{107}$ And this is only one example of a dynamic mechanism. It is also possible e.g. that immigration implies positive scale effects (more on this in Section 7.3), and that it impacts on some important life choices made by natives, such as e.g. their education, fertility, or emigration choices. At a more longterm level, we know even less about how different kinds of immigration affect the workings of society at a deeper level, by influencing factors like openness, national identity, attitudes towards redistribution, trust, social cohesion, etc.

A minority of studies attempt to account for some of these dynamic feedback mechanisms by explicitly modelling the relationships involved. Hence for example if immigration increases the fraction of children in the population, native fertility is assumed to decrease according to an assumed response parameter. Recent Nordic studies in this vein of research include Schou (2006), Holmøy and Strøm (2012), and Hansen et al. (2015).

Yet our knowledge about the true structures and parameter values of these feedback mechanisms is weak. Typically each mechanism in itself represents an unresolved empirical research question, and even less is known about how to appropriately model their interactions in a dynamic model. Studies also differ substantially in which types of mechanisms are at all included in the model, and these choices have vast impact on the results. A good example is how the results from recent Nordic studies in this dynamic vein differ from non-dynamic studies and, more strikingly, from each other. Holmøy and Strøm (2012) estimate a discounted lifetime net cost (see Section 7.3.3 on what that is) of non-European immigration in Norway that is at least three times as high as the most comparable non-dynamic estimate by Wadensjö and Orrje (2002) in Denmark. Yet Hansen et al. (2015) - including a different set of feedback mechanisms - estimate one in Denmark that is approximately only onetwentieth as large as that by Wadensjö and Orrje. Exactly which assumptions are crucial

\footnotetext{
${ }^{107}$ We can be quite certain however that over time, the importance of the first should decrease and that of the third should
} increase. 
in creating these large differences is difficult to see for an outside viewer, due to the complexity of these dynamic equilibrium models. One needs to run multiple simulations to see which assumptions are most important. This complexity and sensitivity is probably the main reason why most researchers avoid this dynamic modelling. By contrast, non-dynamic estimates from Sweden and Denmark are always highly similar up to the difference between the two countries in the size of immigration, as they should be given the similarity of the Scandinavian fiscal systems.

\subsubsection{Policy relevance}

In the beginning of this section I gave examples of how the fiscal effects of immigration may be closely related to important policy questions. This is the fundamental reason why these studies should be conducted, although their results may be - and are indeed - used by others with the purpose of stigmatizing immigrants. However this high policy relevance does not apply automatically. Central to the policy relevance of a study is how well defined the question is that it seeks to answer. Implicitly, when we estimate the net fiscal contribution of an immigrant group, we evaluate (subject to the limitations mentioned in the previous subsection) the fiscal impact of the presence of this group. And this is a more obviously policy-relevant exercise for some groups than for others.

Among the studies of arguably most immediate policy relevance are those of the fiscal impact of post-EU-enlargement immigration from Eastern Europe in the UK (Dustmann et al., 2010), and Sweden (Ruist, 2014a,b). With the eastward enlargement of the EU in 2004 and 2007, EU rules of free movement of workers came to apply although with delay in several countries - also to the citizens of the new member states. Because of the large income gap between the old and new member states, many thus feared subsequent large migration of workers that would not be able to support themselves financially, imposing significant burdens on the receiving countries' public finances. The above-mentioned studies evaluate to what extent these fears were realized, by estimating the net fiscal contributions of all immigrants from the relevant countries of origin who arrived in their new host countries after the EU accessions of their home countries. They thus evaluate the fiscal impact of the new policy of free immigration of workers, implicitly compared with a case of no immigration at all from the countries of origin in question. In the present case this is probably the setup that corresponds best to the public concerns that motivated the studies. 
A study with a similarly direct policy connection is Aldén and Hammarstedt's (2016) evaluation of the short-term fiscal impact of refugee immigration in Sweden. In 2015 Sweden received the highest inflow of asylum seekers per capita ever seen in a Western country since the current international asylum framework was introduced in 1967. To inform policy makers on the expected additional net public costs over the following years in consequence of this, Aldén and Hammarstedt evaluate the net fiscal contributions year by year of earlier refugee cohorts that received their residence permits in 2005-07. Their results are thus short-term year-by-year estimates of the fiscal implications of refugee immigration.

Of somewhat less immediate policy relevance is my study (Ruist, 2015) of the fiscal redistribution from the rest of the population to the entire population of refugee immigrants and their family members in Sweden in 2007. This estimate thus attempts to measure the accumulated fiscal impact in one year of several decades of refugee immigration. The motivation behind doing this study was that Sweden has been the Western country with the highest refugee immigration per capita probably every single year since 1983. The fiscal redistribution to the entire refugee population in Sweden can then be interpreted as an accumulated effect of being more generous than all comparable countries for a long time. I saw this as an informative measure in the midst of the refugee crisis in early 2015, when other European countries that had been at around one-tenth of the Swedish per-capita inflow of refugees for a long time claimed they could not afford to take a larger share of the burden. In a different context, I would not have seen the estimate produced in this study as obviously relevant and worth publicizing.

For most other studies in this literature, it is arguably less obvious in relation to which policy(-ies) they are relevant. The typical study is performed at the highest possible level of aggregation, i.e. it estimates the fiscal redistribution between all immigrants and all natives in a country. Partly this can be explained by the fact that in several countries there is no data that enables a finer analysis, i.e. the only available information is whether an individual is a native or an immigrant. Yet also in the Nordic countries, where the data does enable finer analysis, the majority of studies focus on this the most aggregated level. If they are at all concerned with finer units, also these tend to be quite highly aggregated like Western / non-Western, or European / nonEuropean immigrants (examples include Wadensjö and Orrje, 2002; Gerdes et al., 2011; Holmøy and Strøm, 2012, Flood and Ruist, 2015). 
The degree to which studies conducted at these high levels of aggregation are informative on the effects of historical, current, or future policy is limited by the fact that the immigrant groups that are studied are the results of decades of changing policies that regulate different types of immigration. For example the total immigrant populations in Denmark or Sweden today is the combined result of among others the liberal labor immigration policies in the 505 and 605 , policies concerning the immigration of these workers' family members in the same and subsequent decades, refugee and related family reunification policies from predominantly the 8os and onward, the common policy on the free movement of workers within the EU since the country's EU accession, and (transition) policies towards Eastern European immigrants following the 2004 and $2007 \mathrm{EU}$ enlargements. Exactly how the results from these studies are to be used to inform policy is often not clear. These studies may thus be at risk of providing the fuel for stigmatization of immigrants, yet without an obvious usefulness. This may in turn be one of the reasons for the resistance sometimes encountered towards the whole idea of estimating the fiscal impact of immigration.

\subsubsection{The time frame}

Appropriately dealing with the time frame is often a complicated task in studies of the fiscal effects of immigration. It would not be so if our interest was predominantly in evaluating the effects of historical immigration. Typically however, researchers' interest lies predominantly in the future impact of current immigration, or of possible policy changes toward (lower or) higher immigration, which is something that can actually be affected today. In this setting, what we typically want to know is: If we allow $X$ extra immigrants of type $Y$ in this year, what will be the net impact of this on public finances in each year from now and into the relevant future? From this we can also calculate as a summary measure the total discounted impact between now and $N$ years into the future as:

$$
\sum_{n=1}^{N} \frac{Z_{n}}{(1+r)^{n}}=\frac{Z_{1}}{(1+r)}+\frac{Z_{2}}{(1+r)^{2}}+\cdots+\frac{Z_{N}}{(1+r)^{N}}
$$

where $Z_{n}$ is the impact in year $n$, and $r$ is the discount factor reflecting that resources obtained or lost in the future are less valued than resources obtained or lost today. The end year $N$ may be set to e.g. the year when the migrant dies, or any number of years 
into the future that is found relevant. Some studies (e.g. Ekberg, 2011; Holmøy and Strøm, 2012) further augment this exercise by considering not the future impact of some extra immigrants in this year only, but a permanent increase in the immigration rate. The impact $n$ years into the future is then the accumulated impact of the extra arrivals in each of these $n$ years.

This information lies in the future, and is therefore not attainable. In principle, the best we can do to estimate it is to study the year-by-year impact of historical immigration of people as similar to type $Y$ as possible. In the short term, this can probably be done with reasonably good precision. For example Aldén and Hammarstedt (2016) plausibly provide a fairly good estimate of the impact over the coming seven years of current Swedish refugee immigration, by analyzing the first seven years of cohorts that arrived around ten years earlier. However, already in this case the potential sources of error are easy to identify. In spite of their efforts to look at "similar" historical refugees, we know little e.g. of how much more difficult it will be for the 2015 cohort of asylum seekers to integrate into the labor market for the sheer reason that this cohort itself is so much larger. Over only seven years, the impact of errors like this is not likely to be overwhelming. Yet when the time horizon of our interest grows, errors will tend to grow exponentially. If we e.g. incorrectly estimate immigrants' future annual income growth by a factor $x$, the error $n$ years into the future is $x^{n}$. With example numbers: if we assume based on historical data that annual income will grow by $2 \%$ per year, but it turns out to grow by $3 \%$ per year, actual income in 25 years will be a full $28 \%$ higher than our prediction.

For this reason, only a minority of studies in this literature do this type of forecasts. The majority instead studies plain cross-sections, i.e. the total fiscal redistribution between all immigrants - or a subgroup thereof - and the remaining population in one year. The number thus reported is then due to a weighted sum of immigrants who arrived 1, 2, 3, etc. years ago, with weights that are typically not reported. In most cases, this is clearly less conceptually relevant than a forecast of the future impact of current immigration. Yet apparently researchers often prefer to report a more precisely calculated number of lower conceptual relevance before a less precisely calculated number of higher conceptual relevance.

There are reasons for this. Indeed, forecasts far into the future tend to change so much from only small changes in the assumptions behind them, that their values must be seen as highly uncertain. The cross-sectional redistribution in one year, while it does not conceptually answer an interesting policy question, is on the other hand quite a 
robust number that may at least give us a proper sense of orders of magnitude. If e.g. we have had refugee immigration for 40 years and the total fiscal redistribution to refugees this year is $X$, then, if we let in refugees in fairly similar numbers also over the next 40 years, the annual redistribution to them 40 years ahead is likely to be a number at least not too far away from X. At the same time, there is no real reason for not breaking this number up and reporting it in more detail, i.e. specifically how it changes (which it very importantly does) with number of years in the country.

Finally a third setup which is a combination of the cross-sectional and forecasting setups is used by Flood and Ruist (2015). We report forecasted future redistribution to/from not only future arrivals but all immigrants from origin $X$, including those who are already present today. We thus estimate the fiscal redistribution $n$ years into the future to/from all then living immigrants from origin $X$. This migrant stock is then the unclear weighted sum of two unclear weighted sums; the latter two being that of immigrants of different lengths of stay in the country who are already present today, and that of immigrants who arrive in each of the next $n$ years. In other words it combines the disadvantages of both setups normally used, i.e. the low conceptual relevance of the cross-section and the uncertainty of the forecasting, while adding no apparent benefit. The result is arguably further from being possible to use for immigration policy evaluation than those of any other setup mentioned in this report, and I do not advice anyone to copy this setup.

\subsection{Calculating the fiscal redistribution}

The previous section outlined central differences between different types of studies of the fiscal effects of immigration. However, having decided on these matters, all studies proceed in basically the same way to calculate the fiscal redistribution between one group and the rest of the population in one year. Differences between studies are mainly due to differences in data quality and the implied extent to which parts of the redistribution must be assumed or proxied rather than directly estimated. The best data quality is typically found in the Nordic countries. Hence I review in detail how the redistribution has been calculated in recent studies using Swedish data. This can then be seen as the best that is possible in terms of data quality, while studies from other countries typically need to base larger shares of their calculations on assumptions. 
In principle, an individual's net contribution to public finances is the sum of their tax and fee payments minus the transfers they receive and their marginal effect on public spending. Conceptually the majority of all public revenues and costs are transactions between the public finances and one single individual. This is so for all direct taxes, payroll taxes, consumption taxes, fees, and individual transfer receipts. Yet there never exists complete individual-level data on all these items, and hence to some degree they too need to be ascribed across individuals in the country based on assumptions. Furthermore, typically a small share of public revenues and a fairly large share of public costs are conceptually transactions between the public sector and larger groups of individuals. Corporate taxes are paid by groups of individuals, i.e. the owners of a company, the cost of a school is a transaction between the public sector and all the pupils in the school, the cost of a road is one between the public sector and all users of the road, etc. Also in these cases assumptions and simplifications are needed to enable ascribing these elements across the population. Below I review in detail how the fiscal redistribution to/from different immigrant groups in Sweden has been calculated in recent studies. Since data sources and quality are very similar, this account is also quite representative for recent studies from Denmark and Norway.

Direct taxes: Direct taxes most importantly refer to income taxes, but also include e.g. property taxes. In Sweden there is information on these in public registers and hence they can be directly measured. In non-Nordic countries it is common to estimate income tax payments from income data.

Payroll taxes: These are taxes paid by the employer in proportion to the employee's wage. Individual-level information is not available to researchers and hence these are estimated from income data.

Consumption taxes: These include most importantly value-added taxes, but also taxes on goods such as air travel, alcohol, etc. Payers are not registered and hence individual taxes must be estimated. Most obviously a household's consumption is proportional to its income, yet in a non-linear way because households with higher income save a higher fraction of their income. In my studies I use aggregate-level data on average consumption levels per income decile of the population, to estimate consumption tax payments of each household, yet other studies assume a linear relationship between income and consumption.

Corporate taxes: These are taxes paid by corporations. Conceptually these taxes could be ascribed across individuals in proportion to their shares of the ownership of each corporation, yet absent such data other methods must be applied. Ekberg (2009) 
ascribe total corporate ownership between all natives and all immigrants in proportion to these groups' total capital income. I//we) ascribe them equally across the population in Ruist (2014a,b) and Flood and Ruist (2015), while I set corporate ownership to zero for refugee immigrants in Ruist (2015). ${ }^{108}$

Other revenues: Public revenues not mentioned above (only a few percent of total Swedish public revenues) are ascribed equally across the population.

Individual transfers: Information on these can be obtained directly from public registers.

Hospital, elderly, and child care, and schooling: Conceptually one could go quite far in ascribing costs like these to specific individuals. The cost of running a school could be ascribed equally across all children in the school. Hospital and elderly care could be ascribed in proportion to individual use. Yet in most cases the required data is not available. However there is more aggregated data on average costs per individual by age interval. Since studies of fiscal redistribution focus on quite large aggregates, this aggregated data should in principle give quite accurate estimates of the total costs of each group, once their age structures are taken into account. However there is typically no information available on whether average costs per individual in an age interval are different for certain immigrant groups. In particular for refugee immigrants we might expect this to be the case. Previous experiences of war and persecution might imply higher costs per individual both in health care and schools. In Ruist (2015) I use information from other sources to roughly account for such differences. I do the same for crime and justice costs, which I also estimate with a markup for refugees. However these adjustments have a fairly limited impact on the results.

Disability care: Ekberg (2009) ascribes these costs similarly to the previous point. In my studies I use individual-level data on disability-related individual transfers, and instead ascribe them equally (i.e. not in proportion to the size of the transfer) across all individuals who receive such a transfer.

Immigrant-specific costs: Some public costs may be ascribed in total to certain immigrant groups. This includes e.g. costs of language training and specific labor market programs.

\footnotetext{
${ }^{108}$ What I think today would be the most appropriate way of doing this is to ascribe corporate taxes in proportion to the groups' shares in total employment, which is what should be most proportional to the groups' respective impact on the presence of corporate activity in the country. In any case, corporate taxes make up a fairly small share of total public revenues, so how they are ascribed does not matter much for the result.
} 
Other costs: Public costs not included in the above-mentioned categories make up a fairly large share of total costs: approximately one-fourth in Sweden. Parts of these are costs that could in principle be ascribed to specific individuals if the necessary data was available. Yet much of it is spending that does not target specific individuals. This includes costs of infrastructure, central administration, defense, foreign aid, etc. The common basic procedure is therefore to ascribe all these costs equally across all individuals. Yet a fairly common alternative is to exclude some of the costs (most commonly defense costs) when doing this. The argument is that the marginal contribution of immigration to these costs is almost zero, since the surface area to defend and cover with infrastructure does not change with immigration. I find this argument generally valid, but too exaggerated when it implies setting marginal costs of immigration to zero. Defense spending is not only a function of demand but also of supply: with a larger population there are more resources to spend on defense. And while infrastructure needs may not grow proportionally if immigrants settle in less densely populated areas, it certainly should do so when they settle in cities. My preferred treatment of these potential scale effects of immigration is to mention in writing that possibly such mechanisms imply that the true effects of immigration are more positive than what a redistribution estimate implies, but to not attempt to model it. Many other researchers disagree though. ${ }^{109}$

One further issue when delimiting the immigrant group of interest is whether to include their native-born children. There are valid arguments both for doing and not doing so. Clearly, the presence of these native-born children in the country is an effect of their parents' immigration. On the other hand since they are native-born, their net fiscal contributions over their lifetimes should be quite (not fully) similar to those of other natives, and hence their impact on calculations relate mainly to how early in life we observe them (although this could be said about the actual immigrants too). As an illustration, the estimated cross-sectional fiscal redistribution to all immigrants is substantially larger in Ekberg (2009) than in Flood and Ruist (2015). The only major methodological difference is that Ekberg includes the native-born children in the immigrant group. Since approximately $70 \%$ of these are still children (0-19 years old) at the time of observation, this has quite a large impact on the results.

\footnotetext{
${ }^{109}$ And sometimes they win. In both of my studies of fiscal redistribution that have been published in peer-reviewed journals, referees have required that I also include results based on adjustments like these in the versions that were eventually published.
} 


\subsection{Results}

In this section I report in detail the results of the two existing studies that estimate the fiscal impact of refugee immigration in Sweden: Ruist (2015), and Aldén and Hammarstedt (2016). Given the similarities between the Nordic fiscal and welfare systems, per refugee these estimates are likely to be representative also of the other Nordic countries, for which similar estimates do not exist. ${ }^{110}$

\subsubsection{The fiscal redistribution to all refugees in Sweden 2007}

In Ruist (2015) I estimate the fiscal redistribution in 2007 from the rest of the Swedish population to the population of refugees and family members of refugees who arrived in Sweden any time before 2007. The most important countries of origin of this group are former Yugoslavia, Iraq, and Iran. The data does not contain information on reason for immigration; hence refugees and their family members are identified from the combination of country of origin and year of immigration. ${ }^{111}$ To the extent that the fiscal impact differs between those classified as refugees and those classified as family members of refugees, this can thus not be identified. It could have been with better data. Yet how to interpret this difference would not be obvious, since who belongs in which category is itself contingent upon current legislation. To a large extent, current refugees are not refugees because of individual political actions, but because they belong to a certain group in a certain area; and this often applies to the whole family. Hence those who enter the country as family members of refugees would often themselves have qualified as refugees, if the family had instead chosen to move as a unit.

A summary of the results is shown in Table 1. Column (1) summarizes total Swedish public revenues and costs in 2007. By construction (when including the fiscal surplus on the cost side) these sum to zero. Column (2) similarly summarizes the revenues and costs that relate to the refugee population. Here we see that total costs are SEK 32.5 billion larger than total revenues. Hence the total net redistribution to the refugee population amounts to quite exactly $1.0 \%$ of Swedish GDP in that year.

\footnotetext{
${ }^{110}$ The only additional study I am aware of with a specific focus on refugees is Gerdes (2014), using German data.

${ }^{111}$ See Table 1 in Ruist (2015) for the details of which countries and years.
} 
Table 1: Redistribution to refugees through the public sector year 2007

\begin{tabular}{lrrr} 
& $\begin{array}{r}\text { (1) Total population } \\
\text { (billion SEK) }\end{array}$ & $\begin{array}{r}\text { (2) Refugees } \\
\text { (billion SEK) }\end{array}$ & $\begin{array}{r}\text { (3) Refugees share of } \\
\text { total value (\%) }\end{array}$ \\
Public revenues & 1473.3 & 49.4 & 3.4 \\
Direct taxes, individuals & 536.8 & 16.2 & 3.0 \\
Payroll taxes & 391.5 & 15.3 & 3.9 \\
Consumption taxes & 398.6 & 15.9 & 4.0 \\
Direct taxes, corporations & 106.6 & 0 & 0 \\
Other & 39.8 & 2.0 & 5.1 \\
Public costs & 1473.3 & 81.9 & 5.6 \\
Social assistance & 7.8 & 4.3 & 55.4 \\
Pensions & 286.7 & 3.3 & 1.2 \\
Other individual transfers & 195.4 & 18.8 & 9.6 \\
Hospital and elderly care & 240.6 & 9.1 & 3.8 \\
Disability care & 37.2 & 2.1 & 5.7 \\
Schooling and child care & 158.0 & 4.9 & 3.1 \\
Crime and justice & 30.6 & 7.7 & 25.3 \\
Immigrant-specific costs & 22.3 & 6.4 & 28.7 \\
Other & 494.8 & 25.3 & 5.1 \\
Net result & 0 & -32.5 & \\
\hline
\end{tabular}

Note: Reproduction of parts of Table 4 in Ruist (2015). Column (1) contains a summary of Swedish public finances in 2007. Column (2) contains the corresponding amounts that are ascribed to the refugee population in the analysis. Column (3) is the ratio of Column (2) to Column (1). See source for details on how the elements on each row were ascribed across the population (most of the details can also be found in Section 3 of this paper).

Interestingly, this figure is equal to the Swedish target for international development aid, which is conceptually the most comparable item in the public budget. Like refugee admittance, international aid is a humanitarian activity aimed at assisting people from other countries who are in need, although the mechanism of support is highly different. While the net costs of refugee admittance are outside of our direct control, they thus amount to approximately the same value as another cost with similar objectives where we annually confirm in parliament that we find it worth paying.

It is also clear that $1 \%$ of GDP is a significant cost. If refugee admittance had been lower, there would have been substantially more resources available to spend on other things. At the same time, it is far from endangering the fiscal sustainability of the welfare system as such. To do that, the cost would have needed to be several times higher. This conclusion is also interesting from a broader international perspective. Sweden has had the highest per-capita refugee immigration in the Western world since the early 1980s; several times higher than most other European countries. We can thus 
conclude that also refugee immigration at the Western world's record levels does not threaten the welfare system as such.

Column (3) of Table 1 shows the refugee population's share of the total value for each revenue and cost item, i.e. it shows Column (2) divided by Column (1). Here we see that the refugee population is strongly overrepresented on certain cost items, i.e. social assistance, crime and justice, and immigrant-specific costs. On the other hand they are strongly underrepresented on pension costs, since as yet few of them are old. In sum they are only slightly overrepresented in total costs, i.e. they represent $5.6 \%$ of total costs versus $5.1 \%$ of the total population. The difference from the rest of the population is larger on the revenue side, where the refugee population represents only $3.4 \%$ of the total. A discussion of the net costs of refugee admittance often focuses on the cost side, and indeed the fact that refugees receive $55 \%$ of total social assistance payments may appear quite striking. But all those percents do not sum up to a very large amount of currency. Instead the net redistribution to the refugee population is mainly due to the lower revenues. The refugees' lower-than-average revenues represent $80 \%$ of the total net cost.

\subsubsection{The fiscal redistribution over time to 2005-07 refugee arrivals}

The results reported in Ruist (2015) are best interpreted as a measure of the accumulated costs of comparatively high refugee immigration over a fairly long period of time. This number is then a weighted sum of the very different net contributions of different groups who have been in the country for differently long periods of time. Net costs are high in the first years after arrival, when employment rates are very low. As employment rises, net costs fall, and after 10-15 years in the country the average refugee becomes a net contributor for a number of years until they reach old age. ${ }^{112}$ This sum is thus not very informative about the Swedish public sector's expected costs over the coming years as a result of the record-high inflow of refugees in 2015. Such an estimate is instead provided by Aldén and Hammarstedt (2016). They follow cohorts of refugees who immigrated in 2005-07, identified by information on reason for immigration in the data, and estimate their net contributions to public finances year by year for up to seven years.

${ }_{112}$ The number 10-15 years is based on the analysis in Ruist (2015), but was not reported in the article. 
Their main results are shown in Figure 2, which is a reproduction of their Figure 13. In the year after receiving a residence permit, the average refugee implies a net cost of almost SEK 200,000. This cost falls quite linearly over time, and after seven years it is only half as high. If this linear trend continues, the average person will reach the breakeven point after 14 years. If these numbers are valid also for the inflow of asylum seekers in 2015 we can make the following rough projection: Assuming that 90,000 of these individuals will eventually receive a residence permit, the implied extra net costs for Swedish public finances will be almost SEK 20 billion in the year after they receive their permits, and then fall by approximately one-and-a-half billion per year thereafter. Like what was said about the long-term cost reported in Ruist (2015), these are significant costs, yet they are far from endangering the fiscal sustainability of the welfare system. However at the same time they show that refugee inflows that would indeed pose important challenges to the design of the welfare system are not inconceivable. In the fall of 2015 Sweden received around 10,000 asylum applications per week. If this would have continued for a year, with a $50 \%$ acceptance rate it would have applied an inflow of 250,000 people. After a few years, this would plausibly have required redesigns of the Swedish welfare state.

Figure 2: Refugees' net fiscal costs in SEK per capita by years since residence permit

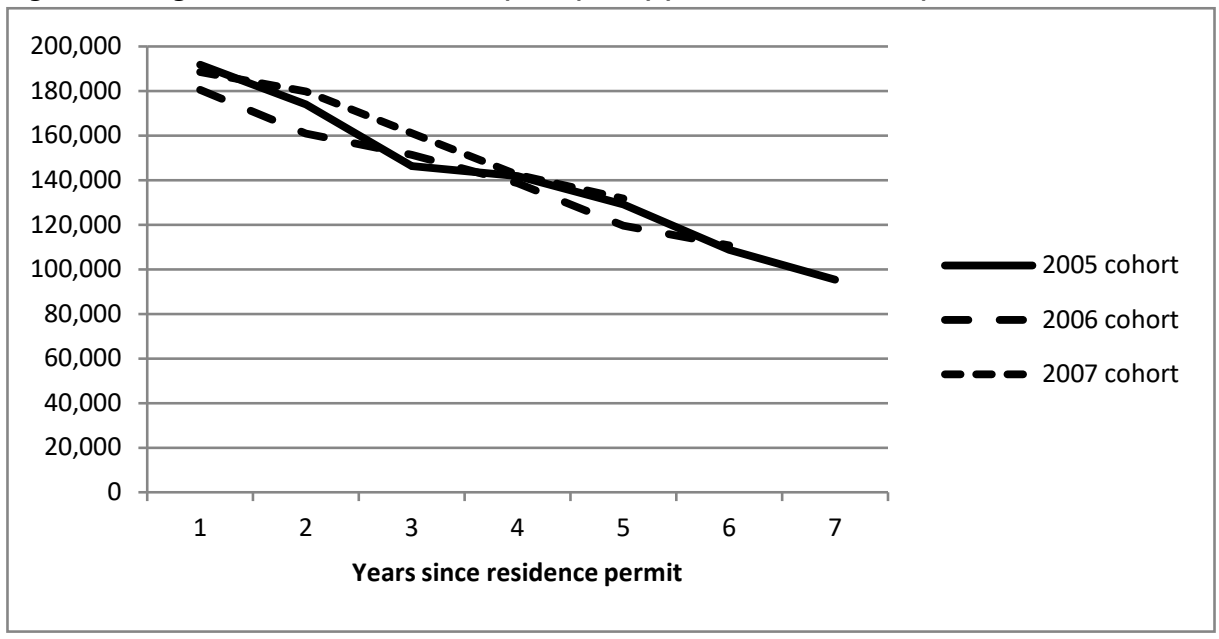

Note: The figure is a reproduction of Figure 13 in Aldén and Hammarstedt (2016). I am grateful to these authors for allowing the reproduction. Each line shows the public sector's estimated net cost in SEK per refugee by cohort and years since residence permit. 
There exists no explicit estimate of the long-term net cost of admitting refugee immigrants. The lifecycle estimates reported by Wadensjö and Orrje (2002) for nonWestern immigrants, and by Flood and Ruist (2015) for non-European immigrants should be seen as underestimates, since the groups studied there are mixes of refugees and economic immigrants, and economic immigrants generally perform better economically. Using a discount rate of $2 \%$, Wadensjö and Orrje estimate a discounted net lifecycle cost of approximately DKK 800,000, and Flood and Ruist of approximately SEK 400,000.

\subsubsection{How much better can it get?}

In spite of the beneficial age structure, refugee immigration thus implies net costs for public finances, in the short and the long run. This is what the historical evidence tells us. One interesting follow-up question is then how much better it can plausibly become in the future, should we succeed better with integrating refugee immigrants on the labor market. The answer to this question largely mirrors the conclusion drawn so far. Also with very high refugee immigration, the costs were not enormously large. Consequently then, even if we succeed in cutting them, the cut will not be enormously large either.

An individual's net contribution to public finances varies almost perfectly linearly with their income. Using 2013 data, I estimated that the net fiscal contribution in SEK of a person who is $20-64$ years old could be well described by the simple formula:

- contribution $=-180,000+0.86 *$ labor income + error

Hence an individual who earns nothing implies a net cost of SEK 180,000, and then the result becomes SEK 0.86 better for each additional krona that the individual earns. If we make a rough assumption that the annual income of an individual who moves from non-employment to employment increases by SEK 250,000, ${ }^{113}$ this implies that their net contribution increases by approximately SEK 215,000. Furthermore, Sweden has approximately 500,000 refugees aged 20-64, and their employment rate is around 20 percentage points lower than that of the rest of the population (Ruist, 2015). With the

${ }^{113}$ This corresponds to a fairly low annual wage, yet not all those who are classified as non-employed have zero annual income. 
numbers above, every percentage point increase in the refugee employment rate will imply a net gain for public finances of approximately SEK 1 billion. Hence even in the quite unrealistic case of a ten percentage point increase (i.e. approximately a closing of half the gap to the rest of the population), the net annual gain for public finances would be no more than around SEK 10 billion. This is not to say that increasing refugees' employment rate is not important. It may be extremely important, yet primarily for reasons related to human well-being and social cohesion rather than public finances.

\subsection{Conclusion}

Estimates of the fiscal effects of refugee immigration - like of other immigration - are rough. A multitude of factors contribute to large margins of error. However the exercise is not futile. The results are still clear and consistent enough to make clear that refugee immigration implies neither heaven nor hell for public finances. It is important to make clear though that allowing refugees to immigrate is a humanitarian activity and should be motivated and assessed as such. Arguments along the lines of "this will be economically beneficial in the long run" should be resisted. We may not know with full certainty that they are false. As I have outlined in this text, important assumptions are made and dynamic mechanisms that are hard to quantify are ignored in the process of reaching the numbers reported. What is clear however is that to turn the estimates positive, one needs to choose an approach to making these assumptions that is quite consistently biased toward the positive side.

At the same time it is clear that refugee immigration is "affordable" at any known historical Western levels, including the recent Swedish record level. This is an important insight especially for other Western European countries that have not even reached one-tenth of the Swedish per-capita level of the decade before the most recent peak. If all $\mathrm{EU}_{15}$ countries had matched the Swedish per-capita inflow rate of this decade, they would have received five million refugees more than they actually did (in fact they received in total 740,000 refugees in 2005-14). This shows that an economically sustainable solution to the European refugee crisis indeed exists, if only there is political willingness. 


\section{References}

Aldén, L. and Hammarstedt, M. (2016), Flyktinginvandring: sysselsättning, förvärvsinkomster och offentliga finanser. Rapport till Finanspolitiska Rådet 2016/1

Dustmann, C., Frattini, T., and Halls, C. (2010), Assessing the fiscal costs and benefits of A8 migration to the UK, Fiscal Studies, 31, 1-41. https://doi.org/10.1111/j.1475-5890.2010.00106.x

Ekberg, J. (2009), Invandringen och de offentliga finanserna, Rapport till Expertgruppen för studier i offentlig ekonomi, 2009:3.

Ekberg, J. (2011), Will future immigration to Sweden make it easier to finance the welfare system? European Journal of Population, 27, 103-124. https://doi.org/10.1007/s10680-0109227-5

Flood, L., and Ruist, J. (2015), Migration, en åldrande befolkning och offentliga finanser, SOU 2015:95, bakgrundsrapport till Långtidsutredningen 2015, Finansdepartementet.

Gerdes, C. (2014), A comparative study of net transfers for different immigrant groups: evidence from Germany. International Migration, 52, 175-208. https://doi.org/10.1111/j.14682435.2009.00573.x

Gerdes, C., Schultz-Nielsen, M., and Wadensjö, E. (2011), The significance of immigration for public finances in Denmark, Study Paper No. 35, The Rockwool Foundation Research Unit.

Hansen, M., Schultz-Nielsen, H., and Tranæs, T. (2015), The impact of immigrants on public finances: a forecast analysis for Denmark, IZA Discussion Paper No 8844.

Holmøy, E., and Strøm, B. (2012), Makroøkonomi og offentlige finanser i ulike scenarioer for innvandring, Rapport 15/2012, Statistisk Sentralbyrå.

OECD (2013), International Migration Outlook.

Pinotti (forthcoming), Clicking on heaven's door: the effect of immigrant legalization on crime, American Economic Review.

Ruist, J. (2014a), The fiscal consequences of unrestricted immigration from Romania and Bulgaria, CReAM Discussion Paper 04/14.

Ruist, J. (2014b), Free immigration and welfare access: the Swedish experience, Fiscal Studies, 35,19-39. https://doi.org/10.1111/j.1475-5890.2014.12021.x

Ruist, J. (2015), The fiscal cost of refugee immigration: the example of Sweden, Population and Development Review, 41, 567-581. https://doi.org/10.1111/j.1728-4457.2015.00085.x

Schou, P. (2006), Immigration, integration and fiscal sustainability, Journal of Population Economics, 19, 671-689. https://doi.org/10.1007/s00148-005-0027-x

Wadensjö, E., and Orrje, H. (2002), Immigration and the public sector in Denmark, Aarhus University Press. 

Nordic Council of Ministers

Ved Stranden 18

DK-1061 Copenhagen K

www.norden.org

\section{Nordic Economic Policy Review}

The 2017 edition of the Nordic Economic Policy Review focuses on labour market integration of immigrants from non-Western countries, educational attainment of refugee children in the Nordic countries as well as the fiscal effects of immigration. The review collates articles from well-known economic researchers from throughout the Nordic region in an attempt to shed light on these issues.

Nordic Economic Policy Review was launched by the Nordic Ministers of Finance in 2009. The review aims to make the latest economic research more accessible to decision makers and contribute to Nordic knowledge exchange on economic policy issues and challenges. The review is produced by the Nordic Council of Ministers and Nordregio.

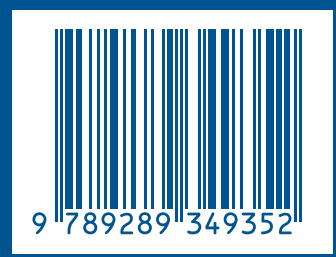

